\title{
BACTERIAL SURVIVAL AT SOLID-AIR INTERFACES: FROM INDIVIDUAL RESPONSE TO POPULATION ECOLOGY
}

\author{
by \\ Roshanak Pashang \\ Bachelor of Science, Ryerson University, 2012 \\ A thesis presented to Ryerson University \\ in partial fulfillment of the requirements \\ for the degree of \\ Master of Applied Science \\ in the Program of Environmental Applied \\ Science and Management
}

Toronto, Ontario, Canada, 2016

CCopyright by Roshanak Pashang 2016 


\section{AUTHOR'S DECLARATION FOR ELECTRONIC SUBMISSION OF A THESIS}

I hereby declare that I am the sole author of this thesis. This is a true copy of the thesis, including any required final revisions, as accepted by my examiners.

I authorize Ryerson University to lend this thesis to other institutions or individuals for the purpose of scholarly research.

I further authorize Ryerson University to reproduce this thesis by photocopying or by other means, in total or in part, at the request of other institutions or individuals for the purpose of scholarly research.

I understand that my thesis may be made electronically available to the public. 


\title{
BACTERIAL SURVIVAL AT SOLID-AIR INTERFACES: FROM INDIVIDUAL RESPONSE TO POPULATION ECOLOGY
}

\author{
Master of Applied Science, 2016 \\ Roshanak Pashang \\ Environmental Applied Science and Management \\ RYERSON UNIVERSITY
}

ABSTRACT

Acclimation and flexible response mechanisms are ancient survival modes allowing prokaryotic cells to conquer diverse habitats and maintain viability in nature. Evidently, lack of water significantly impacts cellular response making it vital for individual cells to benefit from population support and access survival means available beyond the cell boundaries. Microscopy of dried bacterial cells at solid-air interfaces suggested that cell membrane breakdown didn't occur for months. Viable counts for Grampositive Arthrobacter spp. and Gram-negative Pseudomonas stutzeri were significantly higher for larger population density during prolonged periods of desiccation and nutrient starvation. Presence of homogenized cells extended short-term survival of Arthrobacter spp. cells, while heat-killed cells significantly extended viability of all populations. It appeared that huddled zombielike cells allow preservation and recycling of essential survival components within a population. Understanding population-mediated survival at solid-air interfaces is key for monitoring and controlling bacteria including in deep geological repositories for nuclear waste management. 


\section{ACKNOWLEDGEMENTS}

I would like to sincerely thank my supervisor Dr. Gideon Wolfaardt for his guidance and for providing me with an opportunity to develop my individuality as an independent scientist and thinker during my undergraduate and graduate studies. Collectively, I thank my dissertation committee, Drs. Otini Kroukamp, Andrew Laursen, Jennifer McKelvie, and Kimberley Gilbride for directing me through the long and winding road of graduate school and for being there along these processes. I give my gratitude to Dr. Otini Kroukamp for his patience and support and to Dr. Andrew Laursen for assisting me to navigate the world of statistical analysis, taking the time to review the details of my research, and providing his insightful comments. Deep and heartfelt thanks to Dr. Kimberley Gilbride for her mentorship, her valuable lessons that helped me to start my career on the right foot, and developing my skills as a scientist.

Over the years my research group has been inspiring me and I owe them greatly for always giving me help when needed. In many ways you have touched my life and each left your mark on this research as well. I thank you all for your support.

During the course of my research, I have been fortunate to be supported by Nuclear Waste Management Organization and I thank them for all of their contributions, especially Dr. Jennifer McKelvie for her valuable discussions, guidance, and input. A very special thanks goes to Simcha Stroes-Gascoyne (AECL) and Fraser King (ICC) for sharing their extensive research experience and recommendations with me. 
I would like to take this opportunity to extend my appreciation to collaborators who supported my study including Department of Biology and Chemistry at Ryerson University, Lyann Sim, Drs. William Yeung, Martina Hausner, Elanna Bester, Stephanie Melles, Lesley Campbell, John Marshall, Warren Wakarchuk, Lynda McCarthy, Ronald Pushchak.

Finally, I thank my family for their support and encouragement during my academic journey. This thesis is dedicated to my grandmother Maryam for her patience, unwavering love, and her passion to encourage those around her to actively seek knowledge. 


\section{TABLE OF CONTENTS}

AUTHOR'S DECLARATION FOR ELECTRONIC SUBMISSION OF A THESIS ii

ABSTRACT iii

ACKNOWLEDGEMENTS iv

TABLE OF CONTENTS vi

LIST OF FIGURES viii

LIST OF TABLES X xiii

LIST OF ABBREVIATIONS AND SYMBOLS Xiv

1 Introduction $\quad 1$

$\begin{array}{lll}1.1 & \text { Background } & 2\end{array}$

$\begin{array}{lll}1.2 & \text { Research focus and rationale } & 5\end{array}$

2 LITERATURE REVIEW $\quad 8$

2.1 Management of used nuclear fuel waste $\quad 9$

2.2 Impact of microbial activities on the evolution of EBS 12

2.3 The challenge of engineering inhibitory dry zones for survival, activity, and growth

$\begin{array}{ll}\text { of bacteria } & 14\end{array}$

$\begin{array}{lll}2.4 & \text { Relative humidity, temperature, and pH } & 21\end{array}$

$\begin{array}{lll}2.5 & \text { Microbial existence and diversity } & 27\end{array}$

$\begin{array}{lll}2.6 & \text { Planktonic, Cluster and Biofilm } & 34\end{array}$

2.7 Survival of vegetative bacterial cells under desiccation 38

$\begin{array}{lll}2.8 & \text { Matric Stress } & 40\end{array}$

$2.9 \quad$ Osmotic Response $\quad 42$

2.10 Methodology: surface associated microbial survival 45

3 HUDDLING TOGETHER TO SURVIVE: CELL DENSITY AND PROXIMITY AS A

SURVIVAL STRATEGY OF NON-SPORE FORMING BACTERIA IN CONDITIONS OF

EXTREME NUTRIENT STARVATION AND DESICCATION $\quad 49$

$\begin{array}{lll}3.1 & \text { Introduction } & \mathbf{5 0}\end{array}$

3.2 Materials and Methods $\quad \mathbf{5 3}$

3.2.1 Isolation and cultivation of bacteria from dry environments $\quad 53$

3.2.2 DNA extraction, PCR amplification, and DNA sequencing 53

3.2.3 Microbial population density and close proximity mediated survival analysis at solid air interfaces

3.2.4 Evaluating the survival of a microbial population based on recycling of nutrients, water,

and essential elements at solid air interfaces $\quad 56$

$\begin{array}{lll}3.2 .5 & \text { Statistical analysis } & 58\end{array}$

$\begin{array}{lll}3.3 & \text { Results } & \mathbf{6 0}\end{array}$

3.3.1 Desiccated cells remain intact long after no viable counts are detected. 60

3.3.2 Population density plays a role in survival of Gram-positive Arthrobacter spp. at glass-air interfaces. 
3.3.3 Population density facilitated maintenance of intact Gram-negative P. Stutzeri bacteria at

glass-air interfaces without influencing viability.

3.3.4 Presence of intact heat-killed cells of Arthrobacter spp. contributes to survival of desiccated Arthrobacter spp. cells during desiccation at glass-air interfaces over time.

3.3.5 Presence of homogenized cells of Arthrobacter spp. enhances viability of desiccated Arthrobacter spp. cells during desiccation at glass-air interfaces over time.

3.4 Discussion

3.4.1 Closeness of cells by bioflocculation enhances survival of prokaryotes under desiccation at solid-air interfaces by localizing the cells in close proximity to their siblings.

3.4.2 Survivors need saviours: vegetative bacteria survive as a community rather than individuals.

3.4.3 A bacterial community relies on huddled zombielike cells that recycle and preserve

nutrients, water, and essential elements at solid-air interfaces to survive.

3.5 Conclusions

4 SEARCHING FOR BACTERIA IN STICKY SITUATIONS: METHODS FOR INVESTIGATING BACTERIAL SURVIVAL AT SOLID-AIR INTERFACES INVOLVING WYOMING MX-80 BENTONITE

4.1 Introduction

83

4.2 Materials and methods

86

4.2.1 Isolation of cultivable aerobic bacteria from Wyoming MX-80 bentonite 86

4.2.2 Characterization of cultivable aerobic bacteria from bentonite 86

4.2.3 Removal of bacterial cells from bentonite 88

4.2.4 Investigating the survival of bentonite isolates after desiccation at glass-air interfaces 88

4.2.5 Investigating the survival of Arthrobacter spp. after desiccation at bentonite-air interfaces

4.3 Results $\quad 92$

4.3.1 Isolation and characterization of cultivable aerobic bacteria isolated from bentonite 92

4.3.2 Removal of bacterial cells from bentonite 92

4.3.3 Survival of bentonite isolates after desiccation at solid-air interfaces 98

$\begin{array}{llr}4.4 & \text { Discussion } & 99\end{array}$

$\begin{array}{llr}4.5 & \text { Conclusion } & 104\end{array}$

5 SIGNIFICANCE, CONCLUDING REMARKS, AND FUTURE RESEARCH RECOMMENDATIONS

105

APPENDIX A

112

APPENDIX B

APPENDIX C 


\section{LIST OF FIGURES}

Figure 1. Total electricity production: 22,668 TWh (IEA, 2014) ...................................3

Figure 2. NWMO, 2015, Artist's Rendition of Deep Geologic Repository (NWMW, 2015) 10

Figure 3. Relative humidity along with relative humidity modulation factor (King, 2009) 23

Figure 4. Monitoring existence of intact dried cells on the surface of glass coverslips by comparing three population densities of Gram-positive and Gram-negative bacteria populations.

Figure 5. Higher population densities lead to better survival at solid-air interfaces. Arthrobacter spp. population density and close proximity mediated survival analysis at solid air interfaces.

Figure 6. Higher population densities lead to increase in the number of intact cells at solid-air interfaces. $P$. stutzeri population density and close proximity mediated survival analysis at solid air interfaces. 66

Figure 7. Presence of heat-killed cells enhances survivorship of Arthrobacter spp. cells under desiccation on a glass substratum over time.

Figure 8. Presence of heat-killed cells enhances survivorship of $\boldsymbol{P}$. stutzeri cells under desiccation on a glass substratum over time.

Figure 9. Presence of homogenized cells enhances the survival of Arthrobacter spp. cells under desiccation on a glass substratum over time. 72

Figure 10.The phylogenetic position of the 10 aerobic bentonite isolates along with the most closely related identified species.

Figure 11. Removal of viable (culturable) Arthrobacter spp. cells from the dried bentonite sheet (on glass coverslips) by (a) vortex or (b) sonication for various time intervals, 24 hours after inoculating coverslips under conditions of desiccation and nutrient starvation and incubation at room temperature. 
Figure 12. a) Removal of viable (culturable) Arthrobacter spp. cells from dried bentonite sheets on glass coverslips, and on solid, dry bentonite. .97

Figure 13. Dry Wyoming MX-80 Bentonite .112

Figure 14. Visualization of Arthrobacter spp. Population 1 T0.25 on the surface of glass coverslips. 114

Figure 15. Visualization of Arthrobacter spp. Population 2 T0.25 on the surface of glass coverslips. .115

Figure 16. Visualization of Arthrobacter spp. Population 3 T0.25 on the surface of glass coverslips. .115

Figure 17. Visualization of $P$. stutzeri Population 1 T0.25 on the surface of glass coverslips. 116

Figure 18. Visualization of $P$. stutzeri Population 2 T0.25 on the surface of glass coverslips. 116 Figure 19. Visualization of $P$. stutzeri Population 3 T0.25 on the surface of glass coverslips. 117 Figure 20. Visualization of Arthrobacter spp. Population 1 on the surface of glass coverslips. .118

Figure 21. Visualization of Arthrobacter spp. Population 2 T1 on the surface of glass coverslips. .118

Figure 22. Visualization of Arthrobacter spp. Population 3 T1 on the surface of glass coverslips. .119

Figure 23. Visualization of $\boldsymbol{P}$. stutzeri Population 1 T1 on the surface of glass coverslips. 120

Figure 24. Visualization of $\boldsymbol{P}$. stutzeri Population 2 T1 on the surface of glass coverslips.120

Figure 25. Visualization of $\boldsymbol{P}$. stutzeri Population 3 T1 on the surface of glass coverslips.121

Figure 26. Visualization of Arthrobacter spp. Population 1 T3 on the surface of glass coverslips. 122

Figure 27. Visualization of Arthrobacter spp. Population 2 T3 on the surface of glass coverslips. 122 
Figure 28. Visualization of Arthrobacter spp. Population 3 T3 on the surface of glass coverslips. 123

Figure 29. Visualization of $\boldsymbol{P}$. stutzeri Population 1 T3 on the surface of glass coverslips.124 Figure 30. Visualization of $\boldsymbol{P}$. stutzeri Population 2 T3 on the surface of glass coverslips.124 Figure 31. Visualization of $P$. stutzeri Population 3 T3 on the surface of glass coverslips.125

Figure 32. Visualization of Arthrobacter spp. Population 1 T6 on the surface of glass coverslips. 126

Figure 33. Visualization of Arthrobacter spp. Population 2 T6 on the surface of glass coverslips. 126

Figure 34. Visualization of Arthrobacter spp. Population 3 T6 on the surface of glass coverslips. 127

Figure 35. Visualization of $\boldsymbol{P}$. stutzeri Population 1 T6 on the surface of glass coverslips.128

Figure 36. Visualization of $\boldsymbol{P}$. stutzeri Population 2 T6 on the surface of glass coverslips.128

Figure 37. Visualization of $\boldsymbol{P}$. stutzeri Population 3 T6 on the surface of glass coverslips.129

Figure 38. Visualization of Arthrobacter spp. Population 1 T8 on the surface of glass coverslips. 130

Figure 39. Visualization of Arthrobacter spp. Population 2 T8 on the surface of glass coverslips. 130

Figure 40. Visualization of Arthrobacter spp. Population 3 T8 on the surface of glass coverslips. . .131

Figure 41. Visualization of $P$. stutzeri Population 1 T8 on the surface of glass coverslips. 132 Figure 42. Visualization of $\boldsymbol{P}$. stutzeri Population 2 T8 on the surface of glass coverslips.132 Figure 43. Visualization of $\boldsymbol{P}$. stutzeri Population 3 T8 on the surface of glass coverslips.133

Figure 44. Visualization of Arthrobacter spp. Population 1 T15 on the surface of glass coverslips. 134 
Figure 45. Visualization of Arthrobacter spp. Population 2 T15 on the surface of glass coverslips.

Figure 46. Visualization of Arthrobacter spp. Population 3 T15 on the surface of glass coverslips. 135

Figure 47. Visualization of $\boldsymbol{P}$. stutzeri Population 1 T15 on the surface of glass coverslips. 136

Figure 48. Visualization of $P$. stutzeri Population 2 T15 on the surface of glass coverslips.136

Figure 49. Visualization of $\boldsymbol{P}$. stutzeri Population 3 T15 on the surface of glass coverslips.137

Figure 50. Visualization of Arthrobacter spp. Population 1 T28 on the surface of glass coverslips 138

Figure 51. Visualization of Arthrobacter spp. Population 2 T28 on the surface of glass coverslips. 138

Figure 52. Visualization of Arthrobacter spp. Population 3 T28 on the surface of glass coverslips. 139

Figure 53. Visualization of $\boldsymbol{P}$. stutzeri Population 1 T28 on the surface of glass coverslips.140

Figure 54. Visualization of $\boldsymbol{P}$. stutzeri Population 2 T28 on the surface of glass coverslips.140

Figure 55. Visualization of $\boldsymbol{P}$. stutzeri Population 3 T28 on the surface of glass coverslips.141

Figure 56. Qualitative results for agar imprinting. A) T170 inverted coverslip with dried Bacillus spp. 1047 cells (BIS 1). 160

Figure 57. Qualitative results for agar imprinting. C) T170 inverted coverslip with dried Arthrobacter spp. cells (BIS 3). .161

Figure 58. Qualitative results for agar imprinting. E) T170 inverted coverslip with dried Brevibacterium spp. (BIS 5). 162

Figure 59. Replicate 1 for Arthrobacter spp. cells inoculated onto a black polycarbonate filter (viable culturable colonies were counted at about $10^{1} \mathrm{CFU} / \mathrm{mL}$ ). 164

Figure 60. Replicate 2 for Arthrobacter spp. cells inoculated onto a black polycarbonate filter (viable culturable colonies were counted at about $10^{1} \mathrm{CFU} / \mathrm{mL}$ ). 164 
Figure 61. Replicate 1 for Arthrobacter spp. cells inoculated onto a microscope slide (viable culturable colonies were counted at about $\left.10^{1} \mathrm{CFU} / \mathrm{mL}\right)$................................ 165

Figure 62. Replicate 2 for Arthrobacter spp. cells inoculated onto a microscope slide (viable culturable colonies were counted at about $\left.10^{1} \mathrm{CFU} / \mathrm{mL}\right)$................................ 165

Figure 63. Replicate 1 for Arthrobacter spp. cells inoculated onto a black polycarbonate filter (viable culturable colonies were counted at about $10^{2} \mathrm{CFU} / \mathrm{mL}$ ). 166

Figure 64. Replicate 2 for Arthrobacter spp. cells inoculated onto a black polycarbonate filter (viable culturable colonies were counted at about $10^{2} \mathrm{CFU} / \mathrm{mL}$ ). 166

Figure 65. Replicate 1 for Arthrobacter spp. cells inoculated onto a microscope slide (viable culturable colonies were counted at about $10^{2} \mathrm{CFU} / \mathrm{mL}$ ). 167 


\section{LIST OF TABLES}

Table 1. Comparison of Geochemical Characterization of Wyoming MX-80 bentonite16

Table 2. Comparison of relevant findings on the effects of desiccation on bacterial survival at solid-air interfaces involving Wyoming MX-80 bentonite in conditions relevant to the Canadian vault design 30

Table 3. Treatment conditions for validation of cell removal from unsaturated bentonite clays

Table 4. Summary of relevant findings on the effect of desiccation on the identified isolated indigenous bacteria from bentonite clays 95

Table 5.Loss of viable cells (culturable) for bacterial strains isolated from bentonite (isolates 1, 2, 3, 4, 6, 9) or indoor air (Ronan et al., 2013). Cells inoculated to glass coverslips, and maintained under conditions of desiccation and nutrient starvation. Loss represented as first-order rate of decrease. The relative humidity was maintained at $42 \pm 3 \%$ throughout the experiment with exception of the first 4 hours (at ambient RH $(60 \pm 5 \%))$ .98

Table 6. Inoculated population density of monitored bacterial populations on the surface of coverslips 113

Table 7. Description of morpho-types and identity of isolated bacteria from MX-80 bentonite 158

Table 8. Assessing viability of isolated bacteria using agar imprinting 159 


\section{LIST OF ABBREVIATIONS AND SYMBOLS}

\begin{tabular}{|c|c|}
\hline Abbreviation/Symbol & Designation \\
\hline$\left(\mathrm{SO}^{2-}\right)_{4}$ & Sulfate \\
\hline / & or \\
\hline$\%$ & Percent \\
\hline${ }^{\circ} \mathrm{C}$ & Degree Celsius \\
\hline$=$ & is equal to \\
\hline 16S rRNA & 16s ribosomal RNA \\
\hline AECL & Atomic Energy of Canada Limited \\
\hline Am. Coll. Co & American Colloid Company \\
\hline ANOVA & Analysis of variance \\
\hline AODC & method \\
\hline APM & Adaptive Phased Management \\
\hline As & Arsenic \\
\hline Äspö & Äspö Hard Rock Laboratory \\
\hline ATP & Adenosine Triphosphate \\
\hline$a_{w}$ & Water Activity \\
\hline
\end{tabular}




\begin{tabular}{|c|c|}
\hline Abbreviation/Symbol & Designation \\
\hline BLAST & Basic Local Alignment Search Tool \\
\hline bp & base pair \\
\hline C & Substrate concentration \\
\hline $\mathrm{C}_{0}$ & Initial number of cells \\
\hline $\mathrm{Ca}$ & Calcium \\
\hline CA & Canada \\
\hline $\mathrm{Ca}^{2+}$ & Calcium ions \\
\hline $\mathrm{Cd}$ & Cadmium \\
\hline cells $/ \mathrm{mL}$ & cells per milliliter \\
\hline$C_{f}$ & Final Concentration \\
\hline $\mathrm{CFU} / \mathrm{g}$ & Colongy-forming unit per gram \\
\hline $\mathrm{Cl}^{-}$ & Chloride ion \\
\hline $\mathrm{cm}$ & centimetre \\
\hline $\mathrm{cm}^{3}$ & centimetre cubed \\
\hline $\mathrm{Cmol} / \mathrm{kg}$ & Centimole per kilogram \\
\hline Co & Cobalt \\
\hline $\mathrm{Cr}$ & Chromium \\
\hline
\end{tabular}




\begin{tabular}{|c|c|}
\hline Abbreviation/Symbol & Designation \\
\hline $\mathrm{C}_{\mathrm{t}}$ & Number of cells at a given time \\
\hline $\mathrm{Cu}$ & Copper \\
\hline \multirow[t]{2}{*}{$D$} & the substrate diffusion coefficient in the bulk \\
\hline & liquid phase \\
\hline $\mathrm{d}^{-1}$ & per day \\
\hline DGR & Deep Geologic Repository \\
\hline $\mathrm{dH}_{2} \mathrm{O}$ & distilled water \\
\hline DLVO & Dejaguin-Landau-Verweg-Overbeek \\
\hline DMSO & Dimethyl sulfoxide \\
\hline DNA & Deoxyribonucleic acid \\
\hline Dsr & Dissimilatory sulfite reductase \\
\hline e & base of the natural logarithm \\
\hline e.g. & for example \\
\hline EBS & Engineered Barrier Systems \\
\hline EPS & Extracellular polymeric substances \\
\hline Eq. & Equation \\
\hline et al. & more than one author \\
\hline$F$ & $F$-distribution cumulative distribution function \\
\hline
\end{tabular}




\begin{tabular}{|c|c|}
\hline Abbreviation/Symbol & Designation \\
\hline $\mathrm{Fe}$ & Iron \\
\hline$g$ & gram \\
\hline g. $\mathrm{cm}^{-3}$ & gram per centimetre cubed \\
\hline $\mathrm{g} / \mathrm{mol}$ & gram per mole \\
\hline GFP & Green fluorescent protein \\
\hline $\mathrm{gL}^{-1}$ & gram per litre \\
\hline GWe & Gigawatt electric \\
\hline $\mathrm{h}$ & hour \\
\hline$H$ & Effective Film Thickness \\
\hline $\mathrm{HCl}$ & Hydrochloric acid \\
\hline $\mathrm{Hg}$ & Mercury \\
\hline HNMR & Hydrogen-1 nuclear magnetic resonance \\
\hline I & Ionic Strength \\
\hline Inc. & Incorporation \\
\hline$J$ & diffusion flux \\
\hline $\mathrm{J} / \mathrm{kg}$ & Joule per kilogram \\
\hline $\mathrm{K}$ & Potassium \\
\hline
\end{tabular}

xvii 


\begin{tabular}{|c|c|}
\hline Abbreviation/Symbol & Designation \\
\hline $\mathrm{k}$ & the first-order rate coefficient \\
\hline $\mathrm{KCl}$ & Potassium Chloride \\
\hline $\mathrm{kgm}^{-3}$ & Kilogram per meter cubed \\
\hline $\mathrm{L}$ & Depth of a roughness element \\
\hline $\ln$ & Natural Logarithm \\
\hline $\log$ & Logarithm \\
\hline $\mathrm{m}$ & meter \\
\hline M & Moles \\
\hline $\mathrm{Mg}$ & Magnesium \\
\hline $\mathrm{mg} / \mathrm{kg}$ & milligram per kilogram \\
\hline $\mathrm{Mg} / \mathrm{m}^{-3}$ & megagrams per cubic meter \\
\hline $\mathrm{Mg}^{2+}$ & Magnesium ions \\
\hline MIC & Microbial Induced Corrosion \\
\hline $\min$ & Minutes \\
\hline $\mathrm{mL}$ & millitre \\
\hline $\mathrm{mm}$ & millimeter \\
\hline $\mathrm{mM}$ & millimolar \\
\hline
\end{tabular}

xviii 


\begin{tabular}{|c|c|}
\hline Abbreviation/Symbol & Designation \\
\hline $\mathrm{Mn}$ & Manganese \\
\hline Mo & Molybdenum \\
\hline $\mathrm{MPa}$ & megapascal \\
\hline MPN & Most Probable Number \\
\hline MRad & Miliradian \\
\hline $\mathrm{ms}^{-1}$ & meter per second \\
\hline MX-80 & Wyoming bentonite $\mathrm{MX}-80$ \\
\hline $\mathrm{N}$ & Nitrogen \\
\hline $\mathrm{N}$ & Normality equivalents of solutes per litre \\
\hline $\mathrm{N}$-methylated & Nitrogen-methylated \\
\hline $\mathrm{N} / \mathrm{A}$ & Not Available \\
\hline $\mathrm{Na}$ & Sodium \\
\hline NA & Numerical Aperture \\
\hline $\mathrm{Na}^{+}$ & Sodium ion \\
\hline $\mathrm{Na}_{2}\left(\mathrm{SO}^{-}\right)_{4}$ & Sodium Sulfate \\
\hline $\mathrm{NaCl}$ & Sodium Chloride \\
\hline $\mathrm{NaOH}$ & Sodium Hydroxide \\
\hline
\end{tabular}




\begin{tabular}{|c|c|}
\hline Abbreviation/Symbol & Designation \\
\hline NCBI & National Center for Biotechnology Information \\
\hline $\mathrm{Ni}$ & Nickel \\
\hline NJ & New Jersey \\
\hline NWMO & Nuclear Waste Management Organization \\
\hline NY & New York \\
\hline$O-$ & $\begin{array}{l}O \text {-linked glycosylation of a sugar molecule to } \\
\text { an oxygen atom }\end{array}$ \\
\hline $\mathrm{OH}$ & Hydroxide \\
\hline $\mathrm{ON}$ & Ontario \\
\hline $\mathrm{P}$ & Phosphorus \\
\hline $\mathrm{p}$ & p-value \\
\hline $\mathrm{Pb}$ & Lead \\
\hline PCR & Polymerase Chain Reaction \\
\hline PLFA & Phospholipid-derived fatty acids \\
\hline psi & pound per square inch \\
\hline $\mathrm{r}$ & radius of liquid-vapour interfacial curvature \\
\hline $\mathrm{R} 2 \mathrm{~A}$ & Reasoner's 2 \\
\hline RCF & Relative Centrifugal Force \\
\hline
\end{tabular}




\begin{tabular}{|c|c|}
\hline Abbreviation/Symbol & Designation \\
\hline RH & Relative humidity \\
\hline S & Sulfure \\
\hline SAS & Statistical Analysis Software \\
\hline SD & Standard Deviation \\
\hline Se & Selenium \\
\hline SRB & Sulfate-reducing Bacteria \\
\hline $\mathrm{t}$ & time \\
\hline Tris & Trisaminomethane \\
\hline TSA & Trypticase Soy Agar \\
\hline TSB & Trypticase Soy Broth \\
\hline TWh & Terawatt-hours \\
\hline USA & United States of America \\
\hline $\mathrm{V}$ & different variable \\
\hline $\mathrm{v} / \mathrm{w}$ & Concentration expressed as volume per weight \\
\hline VBNC & Viable But Nonculturable \\
\hline $\mathrm{vol} / \mathrm{vol}$ & Concentration expressed as volume per volume \\
\hline
\end{tabular}




\begin{tabular}{|cc|}
\hline Abbreviation/Symbol & Designation \\
\hline water $/ \mathrm{g}$ & Water per gram \\
\hline wks & weeks \\
\hline $\mathrm{Wm}^{-1} \cdot \mathrm{K}^{-1}$ & Watts per meter Kelvin \\
\hline $\mathrm{x}$ & Spatial coordinate \\
\hline $\mathrm{Zn}$ & Zinc \\
\hline$\beta$ & Dimensionless scaling factor for film covered \\
\hline$\mu \mathrm{spacing}$ between groove elements \\
\hline$\gamma$
\end{tabular}


1 INTRODUCTION 


\subsection{B ackground}

Nuclear power is considered as the largest non-hydro clean energy source for electricity production worldwide with generation of $10.8 \%$ of the total global electricity as shown in Figure 1, in the year of 2012 (WNA, 2015; IEA, 2014; CAN, 2013). Approximately 15\% of Canada's electricity is provided by nuclear power from nineteen reactors with 13.5 GWe of power capacity (WNA, 2015). A major concern for the future of nuclear power generation is permanent disposal, as well as long-term management of highly radioactive waste generated by the power plants. Long-term management of used nuclear fuel is contingent upon development of a method that ensures the safety of humans and the environment (Kremer et al., 2009). The Canadian plan for used nuclear fuel is to isolate and contain the radioactive waste by development of a deep geological repository (DGR) with a multiple engineering barrier system (EBS) constructed at an approximate depth of 500 meters following a process called Adaptive Phased Management (APM) (NWMO, 2011). Selected by the Government of Canada in June 2007, the APM approach recognizes "Choosing a Way Forward: The Future Management of Canada's Used Nuclear Fuel” (NWMO, 2005). 


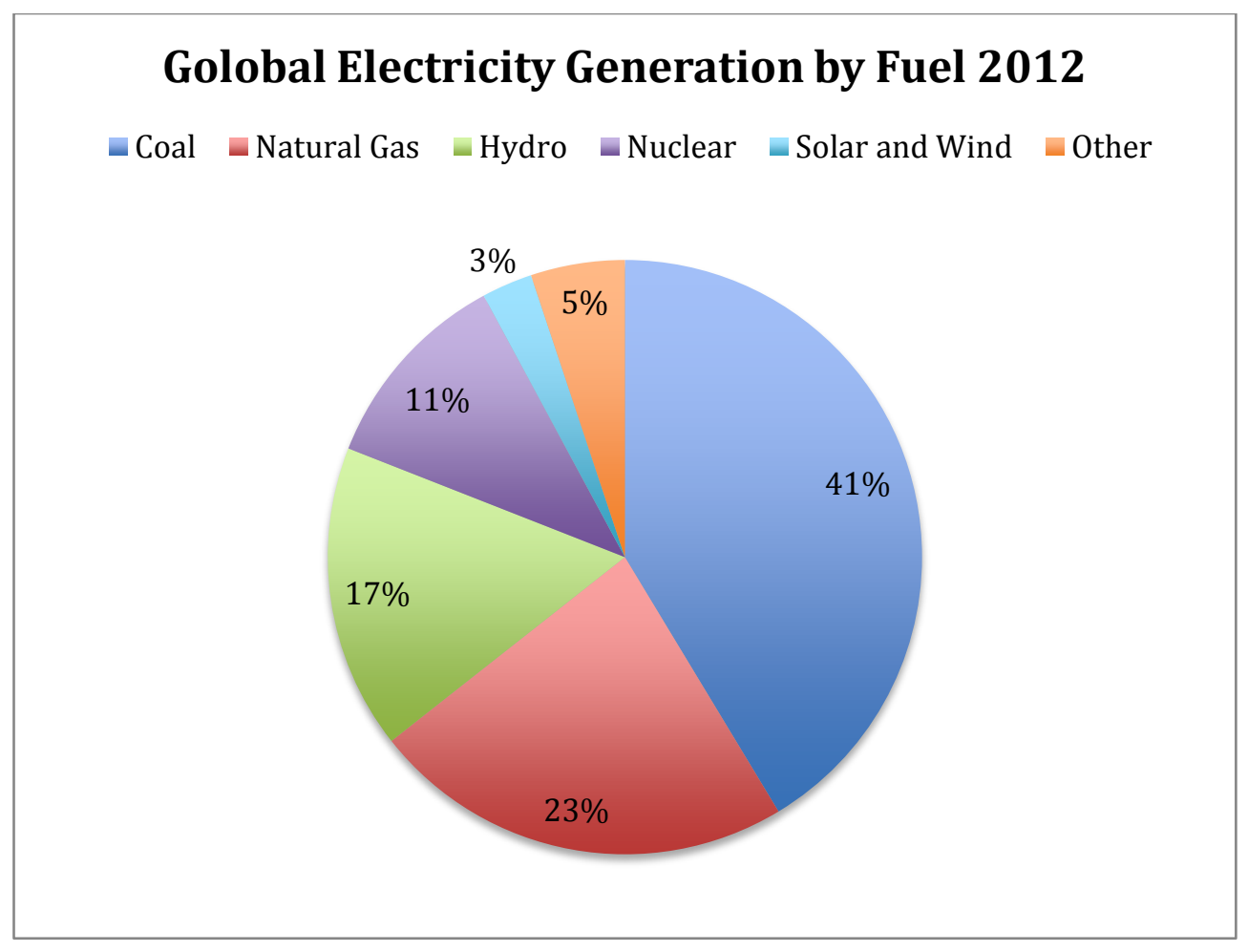

Figure 1. Total electricity production: 22,668 TWh (IEA, 2014)

In order to ensure and assess the long-term safety of Canada's DGR, the potential of microbial existence, ecology, and activities at the various levels of the engineered barriers needs to be considered. The main objectives for assessing presence and diversity of microbes are identifying limitations and providing test designs to further inhibit microbial activity (Crowe et al., 2010). Important microbial implications that are considered for design and performance of DGR include transportation and utilization of radioelements; microbial gas production; changes in geochemical parameters influencing sorption, solubility, and mobility of radionuclides; and microbial induced reactions that lead to microbial influenced corrosion (MIC) of the used nuclear fuel containers (Wolfaardt and Korber, 2012).

The timescale considered for investigating long-term containment of used nuclear fuel is a million years and some of the key processes that lead to alteration within DGR are radiation, thermal and hydraulic conditions, gas and water transport, ion exchange, mineral dissolution 
and precipitation, and microbial activity. In the vicinity of the waste containers, the evolution of EBS is influenced by the alterations within DGR and surrounding environment transforming the nature and the complexity of microbial activities. The initial period for this geological time scale is dominated by aerobic conditions with desiccating high temperature and high radiation. Studies suggest that aerobic microorganisms would only grow during this initial oxidizing period under the influence of severe limiting conditions (Stroes-Gascoyne \& West, 1997). The circumstances affecting microbial activities are expected to become less extreme over time as radioactive decay and high temperature levels are lessened (Stroes-Gascoyne \& West, 1997). Controlling the water activity $\left(a_{w}\right)$ levels of a vault and desiccation is considered as one of the major means for prevention and reduction of microbial survival and activity based on comprehensive studies led by Atomic Energy of Canada Limited (AECL) (StroesGascoyne \& West, 1997). 


\subsection{Research focus and rationale}

Canada plans to store used nuclear fuel and radioactive waste in a deep geological repository (DGR) with a multiple-barrier system constructed at an approximate depth of 500 meters. An inherent challenge is to evaluate the potential influence of microbial survival and activity on the overall performance and integrity of a vault, the near field engineered excavation (consisting of backfill materials, bentonite buffer, used fuel containers) as part of safety assessment and for designing prediction models. Microorganisms in highly compacted bentonite surrounding used fuel containers will be challenged by high pressure, temperature and radiation, as well as limited water and nutrients. Microbial survival and activity close to the emplaced canisters is affected by the combined effects of high temperature, high levels of radiation, absence of water, and lack of available nutrients. Thus it is difficult to estimate microbial activities, given that the prime concern for a microbial community is survival and energy expenditure is regulated. Long-term survival of bacterial cells exposed to air (gaseous phase) during prolonged periods of desiccation at solid-air interfaces is considered as one of the primary obstacles for bacterial survival in a DGR. An in-depth review of collective studies that assess microbial survival and persistence during desiccation in the context of DGR is presented here to augment and direct our prior knowledge about strategies used by bacteria for survival at interfaces in hostile environments including and similar to a DGR.

An important obstacle to assessment of microbiological influences on DGR's concept for long-term management of highly radioactive waste is prediction based on data obtained from short-term studies. While advancement has been made over the last two decades in the area of subsurface microbiology relative to a DGR with multi-barrier systems for used nuclear fuels, 
most available data are design specific to a particular DGR and based on microbial activity measurements at solid-solid or solid-aqueous interfaces. Therefore, as part of a comprehensive study to assess the ecology and survival of bacteria in a hostile environment relative to nearfield microbiology of DGR, this study specifically investigates survival of bacteria under prolonged periods of desiccation at solid-air interfaces.

In order to investigate the survival of bacteria at solid-air interfaces, it is essential to consider that a microbial community will depend on a supply of nutrients, essential elements, and water for cell growth, division, repair, activity, and survival. The carrying capacity for a given surviving bacteria population regulates population size based on the total amount of nutrients, essential elements, and water that is preserved within the community and is available to the members of that population from their surrounding environment. Since cell membranes serve as a barrier that separates the content of the cell from its surrounding environment, inactive cells serve as the only potential reservoirs for nutrients, essential elements, and water when all other sources in the surrounding environment are harnessed. Close proximity of bacteria cells to their siblings during prolonged starvation and desiccation periods may allow access to these reservoirs by cannibalization of the debris of lysed cells minimizing the decline in the carrying capacity. Therefore, density of bacteria populations could play a key role for their survival under desiccation albeit the lack of nutrients at solid-air interfaces. To test this, three different population densities for two different bacteria strains (Gram-negative Pseudomonas stutzeri and Gram-positive Arthrobacter spp.) were selected as test microorganisms. The bacteria were then immobilized on an inert surface (glass coverslips) in a closed system to evaluate bacterial strategies for survival at solid-air interfaces. Population viability, total cell numbers, and morphology (width, length, volume) over time were monitored to investigate survival and persistence of vegetative bacteria at solid-air interfaces. 
Bacteria cell removal techniques after desiccation at solid air interfaces from bentonite clay materials that are considered as a sealing barrier for the design of the Canadian DGR were explored in this study. It was hypothesized that effectiveness of cell removal after desiccation depends on the $\mathrm{pH}$ and absolute temperature of the medium. Selective indigenous bentonite bacteria were isolated and identified from Wyoming MX-80 bentonite clays and their survival was examined on inert glass substratum during desiccation with absence of nutrients.

Collectively, the scope of this study was to examine the role of desiccation under the conditions presented here on the survival of vegetative bacteria at solid-air interfaces and suggested effective measures for setting up survival experiments. Thus, some concepts presented here can be applicable to survival assessment of other microorganisms at solid-air interfaces. 
2 LITERATURE REVIEW 


\subsection{Management of used nuclearfuel waste}

Nuclear energy produces in average approximately 15 percent of Canada's electricity annually and in the year of 2013 nuclear power provided $17.08 \%$ of Canada's electricity (CNA, 2013). Since the start of Canada's nuclear program, approximately 2 million used fuel bundles (about 36 thousand tonnes of uranium) are temporarily stored at facilities where they are originated (Kremer et al., 2009). Nuclear waste management research was initiated in 1978 and

the Seaborn Panel, the first environmental assessment (1998) of the AECL concept of geological disposal in the Canadian Shield, reported that the concept of geological disposal is lacking broad public support. In order to study the options, a waste management agency was recommended and the Nuclear Waste Management Organization (NMWO) was established in 2002 (Kremer et al., 2009).

The government of Canada selected Adaptive Phased Management (APM) in the year of 2007, which is a technical method as well as a management approach for containment and isolation of used nuclear fuel in a DGR (Wolfaardt and Korber, 2012). The Canadian concept for DGR involves a multiple-barrier system that is comprised of four barriers namely: I) The Zircaloy cladding of the nuclear fuel bundles with low solubility for containment ; II) A copper corrosion-resistant container of the used nuclear fuel; III) A clay barrier with high density (MX-80 bentonite) and or sealants that are designed to surround the used nuclear fuel's containers; IV) A stable geological formation that hosts Canada's DGR (Wolfaardt and Korber, 2012; Shoesmith, 2011). The Engineered Barrier System (EBS) involves barrier I-III and together with those parts of the host rock that is in contact or affected by presence of the highly radioactive waste is referred to as "near-field" (Kremer et al., 2009). An example of a 
conceptual design with multiple protective barriers for Canada's DGR concept is illustrated in Figure 2.

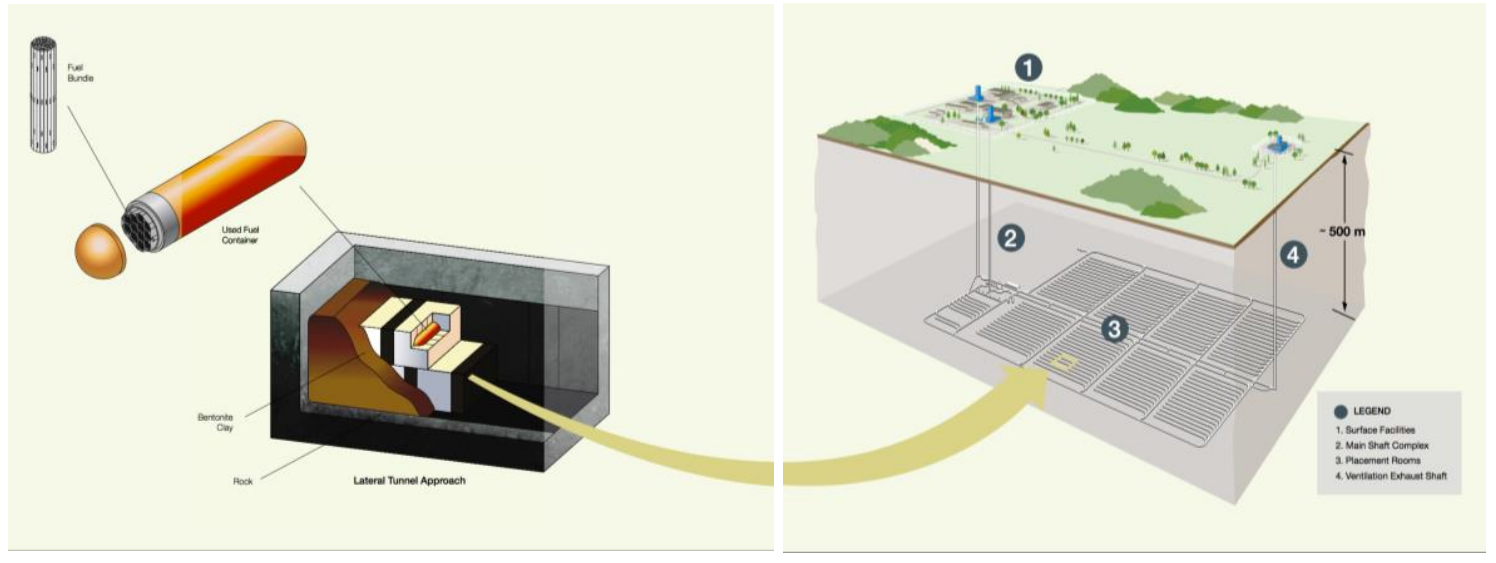

Figure 2. NWMO, 2015, Artist's Rendition of Deep Geologic Repository (NWMW, 2015)

The Canadian APM approach for development of DGR considers a safety assessment for a time frame of a million years during which various temperature shifts (ranging from $55-75^{\circ} \mathrm{C}$ ) would be experienced in the near-field environment due to high levels of radionuclides with both long and short half-lives in used nuclear fuel. The environmental conditions of EBS may potentially change with different DGR concepts and in relation with far-field host rock as well (Wolfaardt and Korber, 2012). Considering all of the EBS components, occurrence of biological processes inside the used nuclear bundles and on the surface of canisters is extremely challenged due to combined effects of high temperature, high levels of radiation, and absence of water and nutrients (McMurry et al., 2003). Therefore, more emphasis on microbiological implications in the outside canister zone on the near-field EBS environment is required for assessment.

Most EBS concepts include a bentonite clay barrier as suitable backfill materials for DGR because of its thermal, hydrogeochemical, and physical properties such as its low hydraulic conductivity and high specific adsorption. Thus, studies suggest that pure bentonite offers 
sufficient microbial activity inhibition when compacted to $2 \mathrm{Mg} / \mathrm{m}^{-3}$, that is water saturated to 26\% v/w ( $\mathrm{a}_{\mathrm{w}}$ of 0.96) (Wolfaardt and Korber, 2012). Previous in situ experiments with a DGR's relevant conditions on the performance of compacted bentonite have demonstrated presence of viable microbes (including heterotrophic and specialized bacteria). The statistical data obtained from this study demonstrated that the limiting factor for viability of bacteria was determined to be the low water content (less than 15\%) of the bentonite for challenging the survival of viable bacteria (Stroes-Gascoyne and West, 1997). Consequently, desiccation can be identified as the major limitation for proliferation, activity, and persistence of bacteria in the bentonite clay's distinct macro- and microenvironment. 


\section{2 Impact of microbial activities on the evolution of $E B S$}

Ongoing studies assess the potential of microbial activities on the overall performance and integrity of EBS in an engineered excavation (vault), in order to determine the potential impacts for safety assessment and prediction models. The conceptual design basis for investigating containment of used nuclear fuel for a vault is on a timescale of millions of years and safety and risk assessment consider the alterations of the key process including, but not limited to, radiation, thermal and hydraulic, gas and water transport, ion exchange, mineral dissolution and precipitation, and microbial activity (Savage et al., 2014). Current studies that relate to microbial activity focus around potential impact of microbial activities such as transportation and utilization of radioelements; microbial gas production; changes in geochemical parameters influencing sorption, solubility, and mobility of radionuclides; and microbial induced reactions that lead to microbial influenced corrosion (MIC) of the used nuclear fuel containers (Wolfaardt and Korber, 2012). In the vicinity of the waste containers, the evolution of EBS due to alterations during a geological timescale, and the surrounding environment will influence the nature and the complexity of microbial activities. The initial period for this geological time scale is dominated by aerobic conditions under desiccation at high temperature and high radiation. It is expected that aerobic microorganisms would only grow during this initial oxidizing period under the influence of these severe limiting conditions (Stroes-Gascoyne \& West, 1997). The circumstances affecting microbial activities are expected to become less extreme over time as radioactive decay and high temperature levels are lessened (Stroes-Gascoyne \& West, 1997). One of the major means for prevention and reduction of microbial survival and activity based on comprehensive studies led by Atomic Energy of 
Canada Limited (AECL) is considered to be maintaining control over the water activity $\left(a_{w}\right)$ levels of a vault and desiccation (Stroes-Gascoyne \& West, 1997).

The hostile physical, chemical, and biological conditions that are dominated at each stage of a geological time scale are complex and dynamic resulting in profound consequences on microbial activities; thus, it is difficult to precisely estimate microbial activities given that the challenging prime concern for a microbial community is survival and persistence. In this review we will discuss the role of desiccation for the survival of microorganisms in hostile environments and how bacteria use survival strategies at dry solid-air interfaces to survive prolonged desiccation periods along with potential implications for future bacterial survival studies. The hostile environmental conditions that are considered for this review include desiccation accompanied with absence of solid surface for attachment, nutrient starvation, and varying changes in temperature and $\mathrm{pH}$ levels at interfaces in a vault that involve inhibitory Wyoming MX-80 bentonite clays. 


\subsection{The challenge of engineering inhibitory dry zones for survival, activity, and growth of bacteria}

In order to isolate the canisters containing highly radioactive wastes, compacted Wyoming MX-80 bentonite blocks are considered to create low permeability zones that fill up the gaps by "self-sealing" based on swelling characteristics of this material, high sorption capacity for water, and low hydraulic conductivity (Johnson et al., 1994; Karnland et al., 2006; Euratom, 2008). The geological term bentonite refers to soil materials consisting of high levels of swelling minerals such as montmorillonite (Karnland et al., 2006). The Wyoming type of bentonite occurs frequently as layers in marine shales and is extensively mined in Wyoming as well as in parts of Montana and South Dakota in the United States. They were formed during the Createceous period more than 65 million years ago through alteration of rhyolitic tephra found in the ancient Mowry Sea basin. Due to spatial variation of Palaessalinity and Palaeoredox conditions within the semi-restricted basin, the chemical signatures of the parent ash are not homogenous and consist of variations in weathering conditions.

The MX-80 material is manufactured by Am. Coll. Co and consists of a mixed natural sodium dominated bentonite horizons, which are dried and milled for smaller grain size (Karnland et al., 2006). The study of the mineralogical characteristics of MX-80 suggested that the mineralogical composition of bentonite plays a significant role in the thermal conductivity and swelling capacity of the clays (Tang and Cui, 2008). A study conducted by Karnland et al. (2006) compares five different types of MX-80 bentonite purchased in different years and suggested that the materials differed significantly in amount and type of accessory minerals, 
dominating charge compensating cation, and content of iron and titanium. They concluded that despite this variation, MX-80 bentonite materials have considerable sealing capacity for all samples. When compacted to $2 \mathrm{Mg} / \mathrm{m}^{-3}$ that is water saturated to $26 \% \mathrm{v} / \mathrm{w}$ ( $\mathrm{a}_{\mathrm{w}}$ of 0.96 ), the approximate background culturable bacteria cell numbers is $200 \mathrm{CFU} / \mathrm{g}$ of dry bentonite with porewater salinity less than or equal to $50 \mathrm{~g} / \mathrm{L} \mathrm{NaCl}$ (Stroes-Gascoyne and Hamon, 2007). It is not known whether the detected low viable culturable bacteria cell counts are associated with insignificant non-homogeneities within the bentonite matrix.

Bentonites are commonly used for sealing purposes in civil and hydraulic engineering such as foundation dike construction, landfill construction, and especially for encapsulation of old waste deposit (Koch, 2002). The properties of bentonite allow for high water vapour absorbance and therefore bentonites are also ideally used as suspending, stabilizing, clarifying, and desiccating agents or as dehydrator agents for gases in many industries (Montes- $\mathrm{H}$ and Gerard, 2004; Montes-H et al., 2005). Solid desiccation agents use an adsorption process that involves bonding of the water molecules by surface force on the surface of the desiccating agent (Montes-H and Gerard, 2004). Association of bacterial attachment to clay particles for increased activity has been observed in marine bacteria (Fletcher, 1985); Thus, it is unclear if water film formation on the surface of a solid desiccating agent at solid-air interfaces can be utilized by microbes or if it allows for microbial attachment.

Further analysis on geochemical composition of MX-80 bentonite is summarized in Table 1, comparing the recent analysis conducted by NWMO with available literature values from previous studies. 
Table 1. Comparison of Geochemical Characterization of Wyoming MX-80 bentonite

\begin{tabular}{|c|c|c|}
\hline Component & $\begin{array}{c}\text { Elemental } \\
\text { Characterization by } \\
\text { H NMR Spectroscopy } \\
\text { (Marshall \& Simpson, } \\
\text { 2014) }\end{array}$ & $\begin{array}{c}\text { Comparison of Available } \\
\text { Geochemical Literature } \\
\text { Values }\end{array}$ \\
\hline $\mathrm{pH}$ & 8.3 & $\sim 8.9$ to $9.5^{\mathrm{F}}$ \\
\hline $\mathrm{CEC}(\mathrm{cmol} / \mathrm{kg})$ & 76.3 & $75-86.3^{\text {b,c,d }}$ \\
\hline Total S (\%) & 0.38 & $0.34^{b}$ \\
\hline Total N $(\%)$ & $\begin{array}{l}\text { Below detectable limit } \\
(<0.05)\end{array}$ & $\mathrm{N} / \mathrm{A}$ \\
\hline Extractable P (mg/kg) & 4.6 & $\mathrm{~N} / \mathrm{A}$ \\
\hline $\mathrm{Fe}(\mathrm{mg} / \mathrm{kg})$ & 21 & $0.0064-0.0068^{\mathrm{a}}$ \\
\hline Nitrate $(\mathrm{mg} / \mathrm{kg})$ & 2.91 & $\mathrm{~N} / \mathrm{A}$ \\
\hline Nitrite $(\mathrm{mg} / \mathrm{kg})$ & 0.200 & $\mathrm{~N} / \mathrm{A}$ \\
\hline \multicolumn{3}{|c|}{ Exchangeable Cations (mg/kg) } \\
\hline $\mathrm{Ca}$ & 4890 & $5210-13627^{\text {b,c,d }}$ \\
\hline $\mathrm{Mg}$ & 1700 & $1142-2187^{\text {b,c,d }}$ \\
\hline
\end{tabular}




\begin{tabular}{|c|c|c|}
\hline Component & $\begin{array}{c}\text { Elemental } \\
\text { Characterization by } \\
\text { H NMR Spectroscopy } \\
\text { (Marshall \& Simpson, } \\
\text { 2014) }\end{array}$ & $\begin{array}{l}\text { Comparison of Available } \\
\text { Geochemical Literature } \\
\text { Values }\end{array}$ \\
\hline K & 560 & $391-782^{b, c, d}$ \\
\hline $\mathrm{Na}$ & 11856 & 11725-13449 b,c,d \\
\hline Mn & 2.29 & $\mathrm{~N} / \mathrm{A}$ \\
\hline \multicolumn{3}{|l|}{ Carbon (\%) } \\
\hline Total & 0.721 & $0.398^{\mathrm{b}}$ \\
\hline Organic & 0.112 & $0.15-0.235^{b, c}$ \\
\hline Inorganic & 0.609 & $0.15-0.163^{\mathrm{b}, \mathrm{c}}$ \\
\hline Water-extractable organic & 0.0095 & N/A \\
\hline \multicolumn{3}{|l|}{ Trace Metals $(\mu \mathrm{g} / \mathrm{g})$} \\
\hline As & 5.3 & $\mathrm{~N} / \mathrm{A}$ \\
\hline Se & 0.13 & $\mathrm{~N} / \mathrm{A}$ \\
\hline $\mathrm{Co}$ & 1.6 & $\mathrm{~N} / \mathrm{A}$ \\
\hline $\mathrm{Cr}$ & 4.5 & $\mathrm{~N} / \mathrm{A}$ \\
\hline $\mathrm{Cd}$ & $<0.2$ & $\mathrm{~N} / \mathrm{A}$ \\
\hline $\mathrm{Cu}$ & 3.2 & $\mathrm{~N} / \mathrm{A}$ \\
\hline
\end{tabular}




\begin{tabular}{|c|c|c|}
\hline Component & $\begin{array}{c}\text { Elemental } \\
\text { Characterization by } \\
\text { H NMR Spectroscopy } \\
\text { (Marshall \& Simpson, } \\
\text { 2014) }\end{array}$ & $\begin{array}{l}\text { Comparison of Available } \\
\text { Geochemical Literature } \\
\text { Values }\end{array}$ \\
\hline $\mathrm{Hg}$ & $<0.035$ & $\mathrm{~N} / \mathrm{A}$ \\
\hline Mo & 2.4 & $\mathrm{~N} / \mathrm{A}$ \\
\hline $\mathrm{Ni}$ & 7.8 & $\mathrm{~N} / \mathrm{A}$ \\
\hline $\mathrm{Pb}$ & 43 & $\mathrm{~N} / \mathrm{A}$ \\
\hline $\mathrm{Zn}$ & 55 & $\mathrm{~N} / \mathrm{A}$ \\
\hline
\end{tabular}

aKarnland et al., (2006); bKarnland (2010); cKiviranata and Kumpulainen (2011); dKumpulainene and Kiviranta (2010); ${ }^{\mathrm{e} M a r s h a l}$ and Simpson, (2014); FStroes-Gascoyne et al. 2010

The ability of microbes to exploit bentonite clays as a source of carbon and nutrients is unknown, since it is governed by limitations imposed on microbial survival and activity due to the hostile environment of the vault. Consequently, nutrient restrictions and complexity is based on chemical characteristics and bioavailability of the substrates for utilization by bacteria. Stroes-Gascoyne et al. (2010) suggested that the small quantity of organic matter that is present in montmoriellion clays might not be bioavailable for microbial degradation and leads to limited availability of a carbon source for microbial survival and activity.

The physical properties of Wyoming MX-80 bentonite clays are considered to significantly limit microbial biomass and activity by restricting the movement of nutrients, metabolic wastes, and potential molecular signals that are released by microorganisms (Poulain et al., 
2008; Stroes-Gascoyne et al., 2007). The two major physical barriers that are offered by bentonite material include low hydraulic conductivity and small pore size of the clay matrix.

The approximate range of hydraulic conductivities within the bentonite matrix ranges from $10^{-13}$ to $10^{-14} \mathrm{~m} \mathrm{~s}^{-1}$. Lack of a significant flow of advective groundwater is expected for the Canadian designed vault and the clay matrix will be diffusion-dominated with low water activity (Stroes-Gascoyne et al., 2007). It is difficult for a bacterial population to thrive and survive in compacted bentonite matrix with this hydraulic conductivity due to space and water limitations that is accompanied with high radiation levels during the aerobic period (StroesGascoyne and West, 1997).

The structure of bentonite material is dependent on the size of the pores formed during the drying process within the clay matrix that can be measured by analytical techniques such as mercury intrusion porosimetry. While smaller pore sizes are independent from the specimen preparation, the larger voids depend on dry density, degree, and manner of compaction for the specimen (Stroes-Gascoyne \& West, 1997). When saturated to $26 \% \mathrm{v} / \mathrm{w}\left(\mathrm{a}_{\mathrm{w}}\right.$ of 0.96$)$, the expected pore size is $<0.02 \mu \mathrm{m}$ in diameter with average pore diameter ranging from $\sim 0.005$ to $0.1 \mu \mathrm{m}$ and low water availability is expected (Mckinley, 1997; Stroes-Gascoyne et al. 2010). Space limitation is considerable since the cell size of most vegetative microbes ranges from 0.5 $10 \mu \mathrm{m}$ (Stroes-Gascoyne et al., 2010). A variety of extremely small bacteria ranging around 0.009 cubic micrometers were collected by Banfield and Comoli (2015) when they filtered groundwater through a 0.2 micrometers filter that were not cultured previously possibly due to possible dependence on other bacteria. Among other small bacteria, the cell size range of microbacteria is $0.2-0.4 \mu \mathrm{m}$ (Stroes-Gascoyne et al., 2010). Changes in cell morphology including cell size is expected as most bacteria are thought to be either in an inactive dormant 
state or with a significantly reduced cell size in a metabolically inactive state (Stroes-Gascoyne et al., 2010).

The transport of microbes through highly compacted buffer material in relation to MIC and radionuclide migration are expected to change over time, since the physical properties of the clay layer such as small porosity limits activity of bacterial populations (Stroes-Gascoyne \& West, 1997). Studies focused on potential microbial migrations through the clay matrix with conditions relevant to Canadian DGR design suggested that bacteria movement is restricted by physical properties of the bentonite barrier. However, presence of Pseudomonas stutzeri was detected on the unsterile segments at the interfaces between the clay plugs and the migration cell used for the study of radionuclide transport. It was concluded that in terms of migration, interfaces are used preferentially by microbes including interfaces that result from crack formation due to desiccation of the clay barrier (Stroes-Gascoyne \& West, 1997). The potential limiting agents and preventive measures for bacterial survival and activity at solid interfaces involving the Wyoming MX-80 bentonite clays needs to be considered for risk assessment, as well as predictive models. 


\subsection{Relative humidity, temperature, and pH}

Microbial homeostasis and growth on solid-air interfaces is significantly influenced by availability of water often denoted by water activity $\left(a_{w}\right)$, which is a thermodynamic parameter related to the free energy (de Goffau et al., 2011). At solid air interfaces, relative humidity $(\mathrm{RH})$ is directly linked to $\mathrm{a}_{\mathrm{w}}$ value of a surface when conditions of equilibrium are reached as described by Hahn-Hagerdal (1986) below (Eq. 1).

$$
\mathrm{a}_{\mathrm{w}}=\mathrm{RH} / 100 \quad(1)
$$

Desiccation is described as reduction in extracellular available water (decrease in external $\left.a_{w}\right)$ resulting in movement of water out of the cell, removing a substantial amount of bulk water from the bacteria cell (Potts, 1994). Interference with essential intracellular processes may arise when the internal $\mathrm{a}_{\mathrm{w}}$ of microbial cells can no longer decrease in order to respond to their external $a_{w}$ to maintain cell homeostasis in the environment. The internal $a_{w}$ threshold of microorganisms is considered to be a "decisive parameter" that can induce changes on morphology (de Goffau et al., 2011). At solid-air interfaces, acclimation is a decisive parameter that is determined by interspecies and intraspecies bacteria interactions, degree and extent of the conditions, and duration of adverse circumstances.

Based on the decisive parameters, in response to desiccation the bacterial cell may use specific and global regulatory systems to coordinate expression of large sets of genes that allow survival and maintenance of cell homeostasis (Gottesman, 1984). In the presence of extremes in temperature, $\mathrm{pH}$ levels, osmolality, lack of nutrient availability, and radiation overlap in regulatory responses may be present under water stress by integration of shared complex networks that determine the physiological response. According to Potts (1994), under water 
stress, the mode and rate of desiccation contributes to the survival of bacteria and their physiological response; therefore, an important aspect of microbial survival at solid-air interfaces that involves bentonite is the physical and geochemical conditions that are present in addition to water stress along with the mode of desiccation.

In the vicinity of the waste canisters, increase in temperature mainly as result of heat generated by radioactive decay leads to desiccation of the bentonite sealing materials. Drying of the bentonite clays occurs at the area that is close to the hot canisters causing fracturing and potentially formation of continuous channels that host water vapour (Pusch and Yong, 2003). In the saturated bentonite with densities of $1.5,1.8$, and $2 \mathrm{~g} . \mathrm{cm}^{-3}$, the value for $\mathrm{a}_{\mathrm{w}}$ is 0.999 , 0.994, and 0.964 based on pure water (Stroes-Gascoyne et al., 2011). The RH in a vault during the unsaturated initial phase is determined by the hygroscopic nature of the montmorillonitebased clays such as Wyoming MX 80 bentonite. The RH of the bentonite clays corresponds to the water activity of the vault and contributes to the moisture distribution within the near field (King et al., 2006). In a number of other natural habitats such as deserts low water activity occurs, as a result of high concentrations of electrolytes (Brown, 1976). According to a study on microbial distribution in two different natural bentonite deposit layers in four sites in Japan by Fukunago et al. (2005), viable heterotrophic bacterial counts were lower than that of soils and aquatic environments and were comparable to dessert environments. The total viable bacterial counts were similar to the counts reported based on samples collected from the surface layer (2 cm deep) of the Western Desert in Egypt (Fukunago et al., 2005).

According to the studies led by (King 2009), the bentonite sealing materials will slowly saturate after tens of years during the evolution of a vault as shown in Figure 3 based on NEUG-GT test case model results for relative humidity prediction. Over time, the thermal 
gradient subsides and the hydration rate is generally dependent on the water pressure and the transient structure of the clays (King, 2009; Pusch and Yong, 2003).

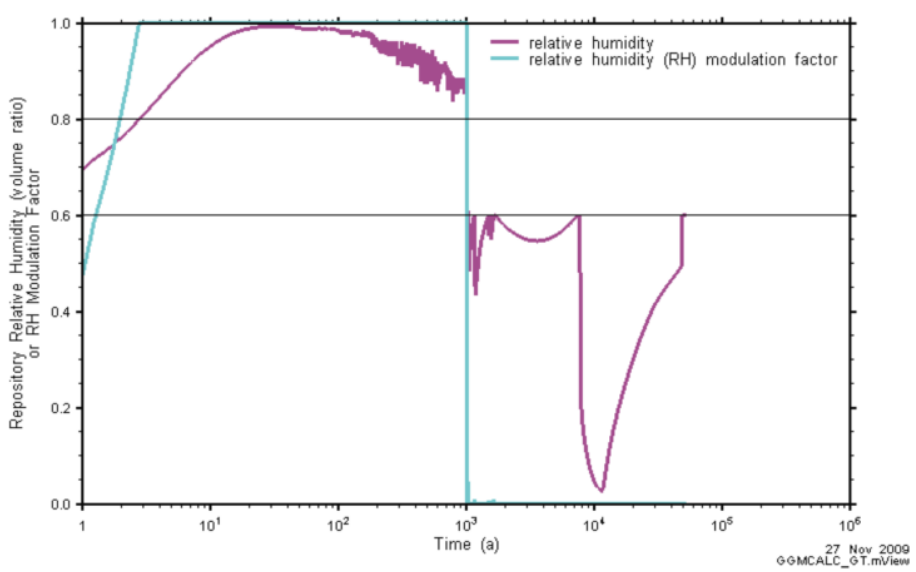

Figure 3. Relative humidity along with relative humidity modulation factor (King, 2009)

With increase in the distance from the canisters in a vault, the maximum temperature along with the degree of desiccation of the sealing materials decreases (King, 2009); consequently, higher temperature, increased desiccation and high radiation levels adversely affect microbial activity and survival at the zones in close proximity to the canisters. The high temperature levels during the initial heat generation period has been associated by various studies with changes in hydraulic characteristics and mechanical response of bentonite material such as hydraulic conductivity (Mingarro et al., 1989; Ouyang and Daemon, 1992; Cho et al., 1999; Cho et al., 2012); water retention (Tang and Cui, 2007; Pusch and Yong, 2003; Villar and Lioret, 2004); water permeability and composition of the pores (Gomez-Espina and Villar, 2009; Villar and Lioret, 2004); swelling pressure (Mingarro et al., 1991; Cho et al., 2012; Lingnau et al., 1996; Villar and Lioret, 2004); swelling and collapse (Villar and Lioret, 2004; Meunier et al., 1998); thermal dilatation, contraction, and compressibility (Lingnau et al., 1996; 
Tang et al., 2008; Villar and Lioret, 2004). There is variation in terms of results obtained and on the type of bentonite clays used, experimental conditions, and saturation levels depending on the influence of dry density under investigation. Thermal conductivity (measure of the property of a material to conduct heat) of the montmorillonite ranges between $0.6-1.1 \mathrm{Wm}^{-1} \cdot \mathrm{K}^{-}$ ${ }^{1}$ for dry density of 1.5 to 2.0 g.cm ${ }^{-3}$ (Mingarro et al., 1991). Cho et al. (1999) investigated the effects of temperature on hydraulic conductivity of compacted bentonite and concluded that hydraulic conductivity increases with an increase in temperature assuming that only the fluid properties are changed with the temperature change.

Studies on the effects of desiccation and high temperature on microbial survival and activity corresponded with a significant drop in viable bacteria counts. However, this decrease in viability was associated with water content of the bentonite clays rather than temperature per se with no culturable viable counts when $a_{w}$ was decreased to approximately $15 \%$ and below (Stroes-Gascoyne \& West, 1997). Therefore, with the MX-80 bentonite barrier, the water content is considered as the main variable that limits bacterial survival and activity. The pore water's composition of MX-80 bentonite changes from $\mathrm{Na}_{2}(\mathrm{SO} 4)^{-}$dominated at dry density of $1200 \mathrm{~kg} \cdot \mathrm{m}^{-3}$ to $\mathrm{NaCl} / \mathrm{Na}_{2} \mathrm{SO}_{4}$ type water when the dry density is $1600 \mathrm{~kg} \cdot \mathrm{m}^{-3}$. The porewater of dry density MX-80 bentonite powder between $1200-1600 \mathrm{kgm}^{-3}$ has a relative ionic strength (I) of approximately 3 and $\mathrm{pH}$ of 8.0. Since the volume of pore water is considerably smaller than the quantity of highly compacted bentonites with high exchange capacity of this material, the composition of the pore water is expected to remain stable (Bradbury and Baeyens, 2003). The $\mathrm{pH}$ level is considered as a major key contributor among physical and chemical parameters for defining biological systems (Horikoshi and Grant, 1998). The availability of $\mathrm{Ca}^{2+}$ and $\mathrm{Mg}^{2+}$ in the surrounding topography affects biological systems since the transportation of ions and substances through the cell membrane is influenced by the 
difference between the internal $\mathrm{pH}$ level and that of the environment. Bacterial primary transport systems allow for proton extrusion, which leads to generation of a proton motive force for ATP synthesis. Proton motive force is a narrow range during bacterial growth phase and consists of the sum of electrical membrane potential and $\mathrm{pH}$ gradient. During the growth phase, the internal $\mathrm{pH}$ is maintained slightly higher to allow for physiological adaption that is required for cell growth (Horikoshi and Grant, 1998).

Bacterial growth is limited when external $\mathrm{pH}$ of the cell's immediate environment is high in the absence of appropriate physiological response (e.g. active proton transport activity) depending on the optimum $\mathrm{pH}$ range of a particular microbial species. For example, halophiles reverse their $\mathrm{pH}$ gradient when the environmental $\mathrm{pH}$ levels are high by lowering their internal $\mathrm{pH}$ levels relative to the external $\mathrm{pH}$ (Horikoshi and Grant, 1998). The presence of major ions in bentonite such as $\mathrm{Na}^{+}$and $\mathrm{Cl}^{-}$leads to a decrease in the extracellular water activity of bacteria and inhibits enzymatic activity when they enter the cell in excess quantity. Bacterial acclimation to high salinity depends on their ability to decrease cytosolic water activity to equilibrate with their environment by maintaining the $\mathrm{Na}^{+}$levels low or by accumulation of compatible solutes (Horikoshi and Grant, 1998). Microorganisms that are in a saline environment prevent water loss by osmosis and related mechanisms. Osmotic acclimation allows for the osmotic potential of the cytoplasm to be similar to the surrounding environment. The osmotic acclimation of Halobacteria transpires when bacterial cells regulate their osmotic potential by a) excluding $\mathrm{Na}^{+}$from the cell and accumulating up to $5 \mathrm{M} \mathrm{KCl}$, or by b) producing or accumulating low-molecular weight compounds that have osmotic potential (Horikoshi and Grant, 1998). 
Microorganisms that are in a saline environment prevent water loss by osmosis and related mechanisms. Osmotic acclimation allows for the osmotic potential of the cytoplasm to be similar to the surrounding environment. The osmotic acclimation of Halobacteria transpires when bacterial cells regulate their osmotic potential by a) excluding $\mathrm{Na}^{+}$from the cell and accumulating up to $5 \mathrm{M} \mathrm{KCl}$, or by b) producing or accumulating low-molecular weight compounds that have osmotic potential (Horikoshi and Grant, 1998). 


\subsection{Microbial existence and diversity}

The Earth's lithosphere is comprised of rocks that contain intergrown minerals and is igneous, metamorphic, or sedimentary. Microorganisms have been detected at lithosphere depth in excess of $3500 \mathrm{~m}$. The subsurface ecosystems host a complex microbial community that depends on the availability of organic matter, which is often deposited during sediment formation or has migrated by ground water from the surface. The metabolic rates in deep subsurface environments are very low due to lack of essential major or minor nutrients (Ehrlich and Newman, 2008). The lack of photosynthesis in deep subsurface environments only allows for the presence of a photosynthesis-independent microbial community that use in situ geochemical energy sources for primary production due to the limited availability of primary production from the Earth's surface (Stevens, 1997).

Microbial abundance along with the metabolic activity potential within the zones that are saturated and hydrologically transmissive is higher as compared to non-transmissive zones due to lack of water and nutrient availability (Madsen, 1995). Within the non-transmissive zones, physical limitations are imposed by subsurface structures that are comprised of restricted pore size. Hence, despite significant reduction in microbial activities within the non-transmissive zones, both organic material and fermentation products could potentially diffuse within different subsurface zones (Krumholz, 1989). For example, excreted organic materials may diffuse from zones with more permeable porous rocks to zones that host fewer microorganisms. Since the available energy for cellular activity is at low levels, survival is the primary source for energy expenditure and not enough metabolites are available for cell growth (Wolfaardt and Korber, 2012). 
In order to survive in hostile environmental conditions such as osmotic stress and starvation, microorganisms adapt through flexible physiology and some bacteria can further resist by differentiation into other form such as endosphores and myxospores. Crossprotector stress responses commonly can be activated when one condition is present, based on the induction of stress regulons, and could lead to further resistance to secondary stress conditions by production of additional de novo protein synthesis during long-term exposure (Jouper-Jaan et al., 1992).

There is limited knowledge available about the mechanisms that allow long-term cell survival, as well as repair mechanisms that are involved in the recovery of the cell function. Further, there is a lack of knowledge about the persistence of bacteria in a dormant state and the modes of action for prevention of spontaneous genomic decay. Johnson et al. (2007) described that low-level cellular metabolism with DNA repair over time is considered more advantageous compared to dormancy for long-term survival and viability. Their study detected vegetative bacterial viability recovered from samples that were frozen for up to half a million years.

Within compacted bentonite, desiccation of cells occurs based on bentonite's strong water affinity and leads to absorbance of extracellular available water, leaving the desiccated cell in a dormant or an inactive state (Masurat et al., 2008). If the dormant cell survives, presence of water leads to restoration of viability and essentially active metabolism (Potts, 1994). It is essential that we fully understand bacterial survival and behavior in inhibitory environments after prolonged desiccation periods relevant to the DGR concept to accurately assess the potential risks to humans and the environment. Since the geosphere's conditions are oligotrophic, there are limitations associated with the results obtained from laboratory experiments (Stroes-Gascoyne and West, 1997). A summary of findings by microbial studies 
on the effects of desiccation on bacteria at low water activity environments relevant to the Canadian vault design is listed on Table 2. 
Table 2. Comparison of relevant findings on the effects of desiccation on bacterial survival at solid-air interfaces involving Wyoming MX-80 bentonite in conditions relevant to the Canadian vault design

\begin{tabular}{|c|c|c|c|c|c|}
\hline Author & Year & Bacteria Species & Source & Methods Used & Summary/Concluding Remarks \\
\hline Aoki et al. & 2010 & $\begin{array}{l}\text { Heterotrophs } \\
\text { Denitrifying bacteria } \\
\text { Nitrate-reducing bacteria } \\
\text { SRB }\end{array}$ & $\begin{array}{l}\text { Indigenous bacteria in Wyoming MX-80 } \\
\text { bentonite }\end{array}$ & $\begin{array}{l}\text {-Acridine orange direct counting technique for total } \\
\text { bacterial counts } \\
\text {-Heterotrophic aerobic culturable bacteria counts using } \\
\text { pour plate method and R2A media } \\
\text {-Set-up at Kamaishi mine, Japan }\end{array}$ & $\begin{array}{l}\text {-Microbial activity is severely limited near waste containers in } \\
\text { the vault for some time after disposal, due to desiccation as } \\
\text { result of heat output of the waste canister } \\
\text {-No viable heterotrophic bacteria as implied by bacteria } \\
\text { counts when water content was less than } 12 \% \\
\text {-Assessing the potential impacts of thermo-hydro- } \\
\text { mechanical effects on microbial activity requires } \\
\text { consideration of desiccation effects relevant to DGR context }\end{array}$ \\
\hline Fru and Athar & 2008 & $\mathrm{~N} / \mathrm{A}$ & $\begin{array}{l}\text { Indigenous bacteria in Wyoming MX-80 } \\
\text { bentonite }\end{array}$ & $\begin{array}{l}\text {-Analysis of } 16 \mathrm{~S} \text { rRNA and } D s r A B \text { gene distribution in } \\
\text { unenriched and enriched samples } \\
\text {-Geological location of approximately } 450 \mathrm{~m} \\
\text { underground, } 30 \mathrm{~cm} \text { wide bentonite blocks compacted to } \\
2.0 \mathrm{tm}^{3} \\
\text {-Placement of a central electric copper heater that could } \\
\text { provide temperature up to } \\
150^{\circ} \mathrm{C}\end{array}$ & 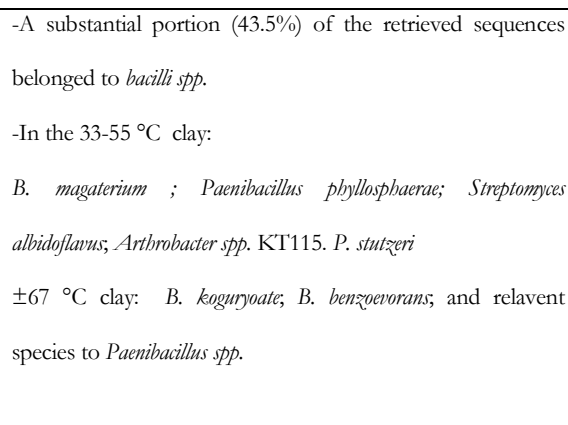 \\
\hline
\end{tabular}




\begin{tabular}{|c|c|c|c|c|c|}
\hline Author & Year & Bacteria Species & Source & Methods Used & Summary/Concluding Remarks \\
\hline Masurat et al. & 2010 & Desulfovibrio africanus & $\begin{array}{l}\text { Indiginous SRB in Wyoming MX-80 } \\
\text { bentonite }\end{array}$ & $\begin{array}{l}\text {-Treated dry bentonite for } 20 \mathrm{~h} \text { in } 100{ }^{\circ} \mathrm{C} \\
\text {-Dry heat before incubation in the growth medium } \\
\text {-Salt concentrations experiments: } 0.7 \% \text { to } 4.0 \%\end{array}$ & $\begin{array}{l}\text {-SRB are present in commercial bentonite } \\
\text {-SRB survive in a state of desiccation at high temperature } \\
\text { and salinity }\end{array}$ \\
\hline Masurat et al. & 2007 & SRB & Indigenous groundwater SRB & $\begin{array}{l}\text {-Exposure to } 120^{\circ} \mathrm{C} \\
\text { Lactate was added as a source of energy for SRB }\end{array}$ & $\begin{array}{l}\text { - Bacterial survival and sulfide production were correlated } \\
\text {-Cell desiccation in bentonite was described as a slow } \\
\text { process that yield higher viability compared to fast } \\
\text { desiccation }\end{array}$ \\
\hline Motamedi et al. & 1996 & $\begin{array}{l}\text { Desulfomicrobium baculatum } \\
\text { Desuffovibrio spp. }\end{array}$ & $\begin{array}{l}\text {-SRB isolated from deep crystalline } \\
\text { bedrock ground water in South-eastern } \\
\text { Sweden at the Äspö hard rock laboratory }\end{array}$ & $\begin{array}{l}\text {-Used swelling pressure odometer } \\
\text {-Varying densities } 1.5-2.0 \mathrm{gcm}^{-3} \\
\text {-Hydrostatic pressure constant at } 2.0 \mathrm{MPa} \text {, incubation at } \\
30^{\circ} \mathrm{C} \\
\text {-Bacteria counts by } \mathrm{AODC} \text { for first time point, MPN } \\
\text { after the first time point }(\mathrm{SD}=0.26)\end{array}$ & $\begin{array}{l}\text {-Survival of SRB in bentonite depend on the availability of } \\
\text { water } \\
\text {-No viable counts for both species at sample density of } 2.0 \\
\mathrm{gcm}^{-3} \text {, aw of } 0.96 \text { with hydrostatic pressure of } 2.0 \mathrm{MPa}\end{array}$ \\
\hline Pedersen et al. & 2000 & $\begin{array}{l}\text { Same as above with addition of } \\
\text { Desuffovibrio aespoeensis }\end{array}$ & $\begin{array}{lccccc}\text { *SRB from } & 600 & \mathrm{~m} & \text { deep } & \text { Äspö } \\
\text { groundwater } & & & & \\
\text { gron }\end{array}$ & $\begin{array}{l}\text {-Culture suspensions were mixed with bentonite clay: } 10^{8} \\
\text { bacteria } / \mathrm{g} \text { dry weight } \\
\text {-Temperature: High } 50-70{ }^{\circ} \mathrm{C} \text {; Low } 20-30^{\circ} \mathrm{C} \\
\text {-Clay blocks surrounded by heated copper tubes inside } \\
\text { vertical boreholes } \\
\text {-Block density of } 2 \mathrm{~kg} \cdot \mathrm{m}^{-3} \\
\text {-Acridine orange direct counts; Plate counts } / \mathrm{MPN} \\
\text { unspecified for which samples } \\
\text {-desiccating environment with aw }=0.76 \\
\text {-none sterile environment }\end{array}$ & $\begin{array}{l}\text {-Spore formation requires energy that takes up to } 4 \mathrm{~h}: \text { may } \\
\text { not be sufficient to form spores due to desiccation effects } \\
\text {-Low numbers of vegetative cells of D.radiophilus were } \\
\text { observed with exception of Psendomonas stutzerr, all other } \\
\text { cultivable bacteria spore forming bacteria } \\
\text {-P. stutzeri was directly isolated before and after heat } \\
\text { treatment: a focused investigation of this particular species } \\
\text { may reveal new information survival strategies of non-spore } \\
\text { forming bacteria }\end{array}$ \\
\hline
\end{tabular}




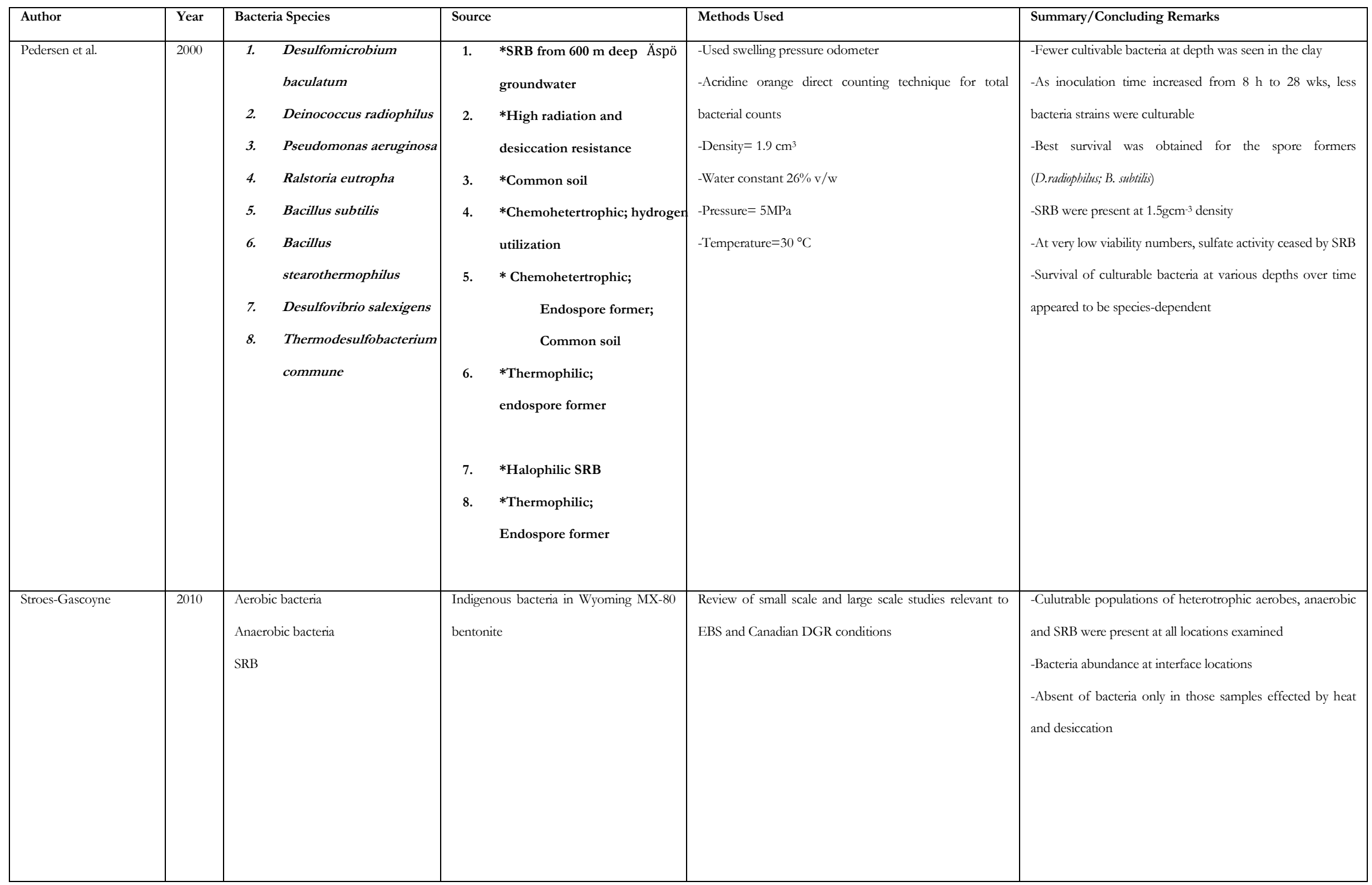




\begin{tabular}{|c|c|c|c|c|c|}
\hline Author & Year & Bacteria Species & Source & Methods Used & Summary/Concluding Remarks \\
\hline Stroes-Gascoyne et al. & 2011 & $\begin{array}{lll}\text { Heterotrophic aerobic } & \text { and } \\
\text { anaerobic bacteria } & & \\
\text { SRB } & & \end{array}$ & $\begin{array}{l}\text { Indigenous bacteria in Wyoming MX-80 } \\
\text { bentonite }\end{array}$ & $\begin{array}{l}\text {-PLFA-based cell counts, MPN } \\
\text {-Reduction in dry density (from } 1600 \mathrm{kgcm}^{-3} \text { to } 1000 \\
\mathrm{kgcm}^{-3} \text { ) } \\
\text {-Used swelling pressure odometer for duration of } 226 \\
\text { days }\end{array}$ & $\begin{array}{l}\text {-High dry density induces/maintains non-culturability (i.e. } \\
\text { VBNC state) in the bacterial population of compacted plugs } \\
\text {-More than } 10^{6} \text { viable cells/g } \\
\text {-The state of VBNC appears not to be progressed to death } \\
\text { phase } \\
\text {-Reduction in dry density in swelling pressure and aw } \\
\text { increased culturability: Reversal of VBNC state or actual cell } \\
\text { division was not distinguished by presented data }\end{array}$ \\
\hline Stroes-Gascoyne et al. & 2010 & $\begin{array}{l}\text { Aerobic heterotrophic } \\
\text { Anaerobic heterotrophic }\end{array}$ & $\begin{array}{l}\text { Indigenous bacteria in Wyoming MX-80 } \\
\text { bentonite }\end{array}$ & $\begin{array}{l}\text { Culture dependent enamuration using R2A medium } \\
\text { Temperature was controlled: } 30{ }^{\circ} \mathrm{C} \\
\text { SRB counts using MPN } \\
\text { Compacted bentonite with dry density of } 8 \mathrm{gcm}^{-3} \\
\text { Porewater salinity of } 0,50 \text {, or } 100 \mathrm{~g} / \mathrm{L} \\
\text { Used swelling pressure odometer for duration of } \\
\text { experiments } \\
\text {-Phospholipid fatty acid analysis }\end{array}$ & $\begin{array}{l}\text {-At high porewater salinity: aw }<0.96 \text { keeps aerobic } \\
\text { culturability below background levels. Under such } \\
\text { conditions, cells likely survive as dormant cells or inactive } \\
\text { spores (as suggested by phospholipid fatty acid analysis) } \\
\text {-Interfacial locations in a DGR could form environments } \\
\text { where (temperature at least) the physical conditions that is } \\
\text { required for inhibition of microbial activity would not always } \\
\text { be met }\end{array}$ \\
\hline
\end{tabular}

* Culture collection with relevance 


\subsection{Planktonic, C1uster and Biofilm}

Long-term survival of vegetative bacteria has been associated with surface attachment and biofilm formation. A bacterial biofilm consists of a bacterial community attached to a substrate capable of producing EPS and exhibiting an altered phenotype compared to the planktonic cells of sample species (i.e. growth pattern, gene transcription, protein production, and intercellular interactions) (Otter et al., 2014). Biofilms are traditionally associated with aqueous environments including damp/wet surfaces. More recently biofilms have been discovered on dry surfaces in desiccated states (Morris and Monier, 2003; Otter et al., 2014). Bacterial biofilms allow for multicellular cooperation by utilizing cellular division of labour, availability of resources that are not achievable by single cells, collective defense against antagonists, and optimized population survival by differentiating into distinct cell types (Shapiro, 1998; Lindsay and von Holy, 2006).

Under most unsaturated conditions survival of free-swimming planktonic microbes is not realistic. In nature, surface attachment is considered as a prevailing life style enhanced by presence of EPS, an effective strategy for adaptation to the variable hydration conditions (Or et al., 2007). Excretion of EPS facilitates bacterial adhesion to surfaces and this process at the mineral interface has been associated with increased mineral alteration (Marshall et al., 1971; Maurice and Warren, 2006). Adhesion is indirect by production of extracellular polymerase substances (EPS) or macromolecule structures. Contradictory results have been obtained from the effects of EPS production on microbial interactions with clays. A detailed review by Or et al. (2007) indicates that while addition of EPS to Ca-montmorillonite induces a secondary mechanism for water retention by formation of inter-particle space, EPS production may lead 
to pore clogging, referred to as bioclogging, depending on the properties of the mineral surface causing reduction in porosity.

Bacterial cells are capable of producing surface layers including capsules, fibrils, and polymers that are mainly composed of polysaccharides providing them with glue like properties for attachment and extension from their surface to the surface of the clay (Theng and Orchard, 1995; Potts, 1994). Strong interactions among cells with solid surfaces through fibrils and polymer structures supports water film development. Water films around a clay envelope, especially montmorillonite clays, can provide the largest surface area for rewetting and protects bacteria from excessive desiccation (Pott, 1994). Retained water on solid surfaces could potentially aid bacteria attachment during the initial colonization stages as well as nutrient diffusion fluxes. However, wet conditions are required for significant contribution to bacteria survival. A study by Or et al. (2007) and colleagues determines the effective film thickness that relies on the relationship between ambient matric potential and average liquid cross sectional area that is available for nutrient diffusion (roughness scaled by its length) of soil particles using Equation 2 presented below.

$$
H(\mu)=\frac{l(\mu)\left(\beta L+2\left[\frac{L}{\cos \left({ }^{\gamma} / 2\right)}-\frac{r(\mu)}{\tan (\gamma / 2)}\right]\right)}{L[\beta+\tan (\gamma / 2)]}
$$

Where $H(\mu)=$ effective film thickness [m]

$\mathrm{L}=$ depth of a roughness element $[\mathrm{m}]$

$\gamma=$ pit or groove angle $\left[^{\circ}\right]$

$\beta=$ dimensionless scaling factor for film covered spacing between groove elements $(\beta \mathrm{L})[\mathrm{m}]$ $\mathrm{r}(\mu)=$ radius of liquid-vapour interfacial curvature $[\mathrm{m}]$ 
Therefore, to determine the one-dimensional diffusion of diffusion flux of substrate $\mathrm{J}$ Equation 3 can be considered:

$J=-D H(\mu) \frac{d c}{d x}(3)$

Where $H=H(\mu)=$ effective film thickness [m]

$D=$ the substrate diffusion coefficient in the bulk liquid phase $\left[\mathrm{m}^{2} / \mathrm{s}\right]$

$C=$ substrate concentration $\left[\mathrm{kg} / \mathrm{m}^{3}\right]$

$x=$ spatial coordinate

The obtained results for soil particles indicated that rough surfaces support a thicker water film when the conditions are wet (matric potential $>-2 \mathrm{~J} / \mathrm{Kg}$ ) and changes in unsaturated conditions changes the effective water film thickness in relation to rough and smooth surfaces when expressed as a function of matric potential $(\mathrm{J} / \mathrm{kg}$ ) (Or et al., 2007; Or et al., 2000). The theoretical values for MX-80 bentonite clay particles are currently unavailable for L, $\beta$, and $\gamma$ values.

Development of large biofilms is inhibited within the bentonite barrier due to significant space limitations (Stroes-Gascoyne and West, 1997). Existence of 'hot spots' or regions with elevated bacterial survival and abundance may harbor larger bacterial densities in inhibitory environments (Or et al., 2007). Particulate organic carbon (the debris of microorganisms) can benefit bacteria populations by providing nutrients, essential elements, and water as they become available based on the portion of population that goes through plasmolysis over time. The presence of small quantities of nutrients does not imply the presence of competent bacteria and in the bentonite matrix mobility of bacteria is significantly restricted, reducing access to nutrients that are not within the immediate range of a bacterial cell. For example, in soil the percentage of available clay surfaces effectively colonized by bacteria is approximately 
$0.02 \%$ (Or et al., 2007). The presence of a low-salinity environment, a high bentonite dry density of $1.6 \mathrm{~g} / \mathrm{cm}^{3}$, and associated high swelling pressure are key components for designing a vault to further control microbial population size growth and suppress microbial activity (Birch et al., 2008). 


\section{7 Survival of vegetative bacterial cells under desiccation}

A study conducted by Johnson et al. (2008) on ancient bacteria within sealed environments indicates that we have limited understanding about the mechanisms that are involved in longterm bacteria survival. It was concluded that strong evidence supports a correlation between long-term survival and cellular metabolic activity and DNA repair, which is superior to dormancy for sustaining viability in surviving cells based on isolated vegetative bacteria in a frozen sealed sample one million years in age (Johnson et al., 2007). Gonzales-Pastor et al. (2014) reported that B. subtilis cells that have entered the pathways involved for sporulation produce and export a killing factor and a signaling protein that blocks sister cells from sporulation by causing them to lyse and allowing them to feed on nutrients thereby released to maintain growth instead of complete morphogenesis. Cannibalism is beneficial for bacterial populations during nutrient deprivation by saving the time and energy required for sporulation, while minimizing viability risks caused by inability of the bacterial cell to return to active growth phase (Allocati et al., 2015). Matin et al. (1989) suggested that the "nondifferentiating" bacteria undergo molecular realignment that allows them to respond to nutrient starvation by synthesizing functional proteins in early phases of starvation for longterm survival. Postgate and Hunter (1962) reported that bacterial death was not immediately accompanied with breakdown of the osmotic barrier and the presence of $\mathrm{Mg}^{2+}, \mathrm{Ca}^{2+}$, or $\mathrm{Fe}^{3+}$ ions delayed death. Despite the wealth of knowledge that was gained by recent studies directed at investigating survival of spore forming bacteria and theories associated with dormancy, spontaneous genomic decay over geological timescales remains unexplained. 
Further studies are required to gain insights about survival of vegetative bacteria at solid-air interfaces within the deep geological repositories and potential implications of dead, inactive, and live intact vegetative bacterial cells on long-term survival of bacteria. 


\subsection{Matric Stress}

Desiccation occurs as a result of reduction in extracellular water potential and can be defined as a loss of a substantial amount of bulk water from bacterial cells by matric stress (Potts, 1994). Under matric stress, the immediate environment that the cell wall is exposed to is atmosphere (a gas phase), in contrast, under osmotic stress cells are immersed in aqueous solutions of greater osmolarity than the cell, and the $\mathrm{a}_{\mathrm{w}}$ of the cell is significantly decreased (Potts, 1994). At the cellular level, some adverse implications of prolonged desiccation include oxidation of DNA, proteins, and membrane components such as fluidity loss of membrane phospholipids (Potts, 1999; Halverson et al., 2000). Many macromolecules lose their threedimensional conformation that is required for biological activity (Halverson et al., 2000).

If cells do not acclimate during desiccation stress, the intracellular turgor pressure of the cell will decrease and can lead to plasmolysis and water will flow out of the cells (Potts, 1994). The internal water content of an average cell is approximately $0.7 \mathrm{~g}$ water $/ \mathrm{g}$ dry weight. Desiccation-sensitive species can only survive with cellular water content higher than $0.3 \mathrm{~g}$ water/g dry weight; while desiccation-tolerant species can survive with internal water content of less than $0.1 \mathrm{~g}$ water/g dry weight (Billi et al., 2000). Desiccation-tolerant species are able to survive and proliferate in dry environments. Thus, the mechanisms involved are poorly understood and are suggested to be associated with both cellular protection and damage repair systems (Potts, 1999).

The rate and duration of desiccation also plays a significant role in long-term survival of bacteria. As the period of desiccation increase, it adversely impacts a bacterial community by selecting for those individuals that are able to survive. Consequently, an increase in the 
desiccation period leads to a decrease in species richness and diversity (Mckew et al., 2011). Bacterial response to dehydration can be specific or global and water stress is mostly accompanied with other stress causing conditions such as nutrient starvation, extreme changes in temperature, and osmolality (Or et al., 2007; Lauten et al., 2010). Thus, overlap in regulatory networks may be present under water stress (Or et al., 2007). To investigate survival under desiccation, it is difficult to identify all of the stress conditions that are involved while mimicking the natural habitat of the microorganism under investigation in laboratory settings. A multi-response model can provide direct insights into acclimation factor associated with desiccation based on collective physiological responses exhibited by a particular bacteria species. For example, increased levels of heat tolerance of desiccated bacteria cells have been reported by a number of studies (Fine and Gervaise, 2005; Laroche and Gervais, 2003; Masurat et al., 2008). In this case survival can be expressed as acclimation factor of the species under investigation during a given desiccation period based on impact of a particular radiation level on the survival of a population expressed as viability by employing basic microbiological techniques. 


\subsection{Osmotic Response}

Osmotic stress is defined as a change in the osmotic strength of the microorganism's environment. Under osmotic stress cells are in contact with an aqueous solution with restricted and high $\mathrm{a}_{\mathrm{w}}$ (Potts, 1994). The active processes that are carried out by microorganisms to regulate cellular osmotic changes are referred to as osmoregulation (Csonka, 1989). The ability of microbes to effectively perform osmoregulation determines their growth, existence, and survival in their particular niche. Regulation of the osmatic balance plays an essential role during the cell growth phase and is considered vital for survival by keeping the cell intact (Csonka, 1989). Osmotic tolerance is considered as an evolutionary advantage that is species-specific and allows a small percentage of microorganisms to remain viable in extremely dry conditions (Schimel et al., 2007; Potts, 1999). Osmotic potential develops within the bentonite clay matrix due to presence of soluble mineral impurities in the saline pore fluids and can increase with a decrease in moisture content (Stroes-Gascoyne and West, 1997). The implications of bentonite clay's osmotic potential on microbial ability for osmoregulation are currently not well studied.

In response to osmotic stress, osmoregulation can occur by a change in the concentrations of a limited number of solutes. Compatible solutes are accumulated during osmotic stress by microorganisms and do not impose a great inhibitory effect on cellular processes for improving survival. The most common compatible solutes in bacteria are $\mathrm{K}^{+}$ions, amino acids (glutamate, glutamine, proline, $\gamma$-aminobutyrate, alanine, the quaternary amines glycinebetaine, and various derivatives of amino acids that are fully $\mathrm{N}$-methylated), and sugars (sucrose, trehalose, $\alpha$-D-glucopyranosyl- $\alpha$-D-glucopyranoside, and glucosylglyceral) (Csonka, 1989). 
Other than osmoprotection, the role of compatible solutes for protection of cells and components of cells from freezing, desiccation, high temperature, and oxygen radicals has been established (Reina-Bueno et al., 2012). In nature, maintaining control over distribution of compatible solutes is species dependent. While ectoine synthesis is specific to halophilic/halotolerant Proteobacteria, Actinobacteridae, and Firmicutes; synthesis of trehalose and glutamate or accumulation of glycine betaine are widespread among microorganisms (Arguelles, 2000).

To further elaborate on the role of osmoregulation by controlling the concentration of compatible solutes, commonly distributed trehalose is extensively studied. The disaccharide trehalose $(O$-alpha,-D-glucosyl-[1 $\Rightarrow 1]$-alpha- $D$-glucoside $)$ has been associated with archaea, bacteria, yeasts, fungi, plants and invertebrates as a universal stress molecule that protects cells from high osmolarity, desiccation, freezing, and heat (Jorge et al., 2008; Reina-Bueno et al., 2012). During desiccation de novo biosynthesis of trehalose that leads to accumulation in bacteria cytosol has been reported as a common response, including in Rhizobium Ieguminosarum bv. trifoliii (McIntyer et al., 2007), Rhizobium etli (Reina-Bueno et al., 2012), Bradyrbizobium japonicum (Streeter, 2003). Biosynthesis of trehalose by preconditioning R. etli cells to osmotic stress was beneficial for tolerance to desiccation (Reina-Bueno et al., 2012). In contrast, for some species of bacteria including Chromohalobacter salexigens and Pseudomonas putida desiccation tolerance was not established in the presence of high trehalose concentrations. MiyamotoShinohara et al. (2008) reported that smooth cell surfaces (such as lack of flagella and pili) and absence of polysaccharides including trehalose and eichoic acid outside the cytoplasm improved long-term survival of freeze-dried cultures of a variety of species analyzed for up to 20 years. 
The impact of matric stress (desiccation) is greater on the survival of microorganisms, since the preferential exclusion mechanisms for cell protection are diminished in absence of an aqueous interface in contact with cells (Potts, 1994). The acclimation factor associated with the survival of a population could potentially depend on the stress conditions that are imposed on that population from their immediate biotic and abiotic environment prior to desiccation. Considering that a desiccation event can occur immediately or over time, the impact of desiccation rate on acclimation factor of a given population is not well known. 


\subsection{Methodology: surface associated microbial survival}

The available literature on the effects of desiccation on the survival of bacteria at solid-air interfaces is limited and most studies are based on pure cultures at interfaces that involve an aqueous phase. Bacteria predominantly exist in a community and the members are able to allocate and distribute their metabolic products and molecular signals (Lynd et al., 2002). Utilization of a wider range of metabolic activities and an ability to share metabolites allows a mixed community of microorganisms to attain higher overall survival success when exposed to various environmental stressors (Brenner et al., 2008). Hence, the members of a mixed community may have a higher survival rate when introduced to desiccation as compared to pure cultures. Biofilm forming bacteria enhance their survival during dehydration by production of extracellular polymeric substances (EPS) and by accumulation of various compatible solutes. As described in Section 2.6, presence of extensive biofilms is not expected within the inhibitory matrix of compacted bentonite. There is need for further investigation of bacteria survival at solid-air interfaces that are considered as potential 'hot spots' within EBS or regions with elevated bacteria survival in the form of clusters under prolonged periods of desiccation.

Considering the complexity of microbial ecosystems especially in subsurface environments, predictions about possible microbial processes based on diversity and distribution are difficult. Diverse bacteria populations thrive and survive as a community in most sedimentary rocks because of a rich supply of organic compounds. In the earth's deep realms, existence of microbial species is dependent on their local subsurface environmental 
conditions and nutrients (Fredrickson and Onstott, 1996). For sustaining metabolic activity, subsurface bacteria require interconnected pore throat size of $>0.2 \mu \mathrm{m}$, which is smaller than most known bacteria. In core bentonite samples with pore throats $<0.2 \mu \mathrm{m}$ in diameter, no metabolic activities including anaerobic mineralization of acetate, glucose, and $\mathrm{SO}_{4}^{2-}$ reduction were detected (Fredickson et al., 1997). In the compacted bentonite with small pore size and high dry density, microbial viability is significantly reduced and at dry density of $0.8 \mathrm{~g} / \mathrm{cm}^{3}$ reduction of approximately $90 \%$ of culturable viable bacteria was observed (Stroes-Gasconyne et al., 2010). Bacterial movements are restricted in deep clay with bacteria trapped in a lattice of small porosity. As a result, surviving bacteria are adapted to a reduced cell division rate over time due to a lack of nutrient availability restricting their essential activities (Boivin-Jahns et al., 1996). Regions of low dry density within highly compacted bentonite possibly at a number of interface locations (placement gaps, contact regions with materials of different densities and contact points with water-carrying fractures in the rock) need to be assessed for the potential of formation of "hot spots" with elevated microbial population density.

There is need for quantitative research on bacterial tolerance of heat and desiccation, in order to determine the acclimation factor for a given bacterial population and survival of bacteria at solid-air interfaces for predictive models and safety assessment purposes. Testing for survival of bacteria under environmental stress conditions in particular has been challenging both practically and theoretically. A main limitation for experimental set-up for survival analysis is controlling all of the physical, chemical, biological factors that contribute to the underlying physiological responses and mechanisms that are involved during exposure, in order to isolate the parameter(s) under investigation. Many statistical assumptions are used for theoretical analysis in particular for distribution normality and using statistical models to monitor bacteria survival. Bacteria survival are commonly expressed as $\mathrm{CFU} / \mathrm{mL}, \log$ 
$\mathrm{CFU} / \mathrm{mL}$, percent $\mathrm{CFU} / \mathrm{mL}$, or percent $\log \mathrm{CFU} / \mathrm{mL}$ over time based on methods employed for population growth pattern analysis. The following alternative approach for conducting experiments that involve survival analysis can be used to determine the rate coefficient (Equation 5):

$$
\mathrm{C}_{\mathrm{t}}=\mathrm{C}_{0} \mathrm{e}^{-\mathrm{kt}}
$$

Where $C_{t}$ is the number of cells at a given time $t$, and $C_{0}$ is the initial number of cells. Taking the natural $\log$ of each side, $\operatorname{Ln}\left(C_{t}\right)-\operatorname{Ln}\left(C_{0}\right)=-k t$, or $\operatorname{Ln}\left(C_{t}\right)=\operatorname{Ln}\left(C_{0}\right)-k t$. Natural logtransformed cell counts can be plotted against time and a linear regression (least-squares) is fitted to the data. The slope of the regression line represents $\mathrm{k}$, the first-order rate coefficient, expressed in units of $\mathrm{d}^{-1}$.

It is now clear that microorganisms are ubiquitous on earth including various hostile habitats and in deep underground environments. Inhibition of microbial activities is vital in various settings to prevent their negative consequences on humans and the environment. Therefore, it is necessary to better understand the intrinsic and extrinsic factors that allow bacteria to withstand stress conditions including prolonged periods of desiccation in dry inhibitory environments.

Further, development of methods for quantification and detection of bacterial cells that survived after exposure to prolonged desiccation periods is vital for better assessment of a target environment. Isolation of environmental bacteria for studying distribution and diversity of a community selects for culturable bacteria only. Approximately $99 \%$ or more of environmental bacteria are not culturable with the current culturing methods employed (Amann et al., 1995). Non-culturability has been observed frequently in subsurface samples (Onstott et al., 1998; Fredrickson et al., 1997) and the PLFA-based results obtained from studies at AECL indicated presence of a large number of viable-but-not-culturable (VBNC) 
cells that were at inactive stage based on in situ studies (Stroes-Gasconyne et al., 2010). Investigations involving microbial survival in nature are complex and loss of culturability for environmental samples has been demonstrated when microbial conditions differ from that of their natural habitat (McDougald et al., 1998). Response of vegetative bacteria as VBNC to various adverse environmental conditions can be analogous to formation of endospores by some bacteria (Stroes-Gascoyne et al., 2011). Physiological changes such as thickening of cell wall and cytoplasmic membrane and condensation of the genetic materials in the cell have been associated with non-culturability of vegetative bacteria (McDougald et al., 1998). Thus, the physiological bases for initiation and termination of vegetative cells for the VBNC stage remains unknown. Also, unclear is whether the state of bacteria under investigation is VBNC, inactive, or dead when the cell membrane is still intact and viable counts diminish. 
3 HUDDLING TOGETHER TO SURVIVE: CELL DENSITY AND PROXIMITY AS A SURVIVAL STRATEGY OF NON-SPORE FORMING BACTERIA IN CONDITIONS OF EXTREME NUTRIENT STARVATION AND DESICCATION 


\subsection{Introduction}

Prokaryotic populations in nature are in a dynamic state and some species have complex developmental processes in their life cycle to enhance their long-term survival and persistence during adverse abiotic conditions (Angert, 2005; Johnson et al., 2007). For example during growth phase at solid-aqueous interfaces, the vegetative cells of some bacterial species differentiate into various resistant forms that results in thickened extracellular cell wall with distinct physiological and structural characteristics including endospores (Terracciano et al., 1988; Veening et al., 2008), polyendospores (Angert, 2005), exospores (Whittenbury and Dow, 1977; Bowman et al., 1993), myxospores (Hanson and Dworkin, 1974; Tzeng et al., 2006), cysts (Gagle and Vela, 1971; Maldonado et al., 1994), and akinetes (Argueta et al., 2006). Taking on a resistance form involves a complex, energy-intensive mechanism that poses high risk for loss of viability before or during resuscitation for a microbial cell and remains a last resort for many species of bacteria (Gonzeles-Pastor et al., 2003). During nutrient deprivation, the spore forming bacterium Bacillus subtilis releases extracellular killing factors to induce programmed cell death in siblings, releasing nutrients and allowing B. subtilis to grow instead of undergoing morphogenesis (Gonzalez-Pastor et al., 2012; Aocati et al., 2015). Maintaining a vegetative state allows for low-level cellular metabolic activity and DNA repair for prevention of spontaneous genomic decay for long-term survival (Johnson et al., 2007), which enhances and alleviates microbial transition into full metabolic activity during the resuscitation stage.

Hence cellular stress response pathways and additional population-regulated mechanisms that allow long-term survival of bacteria in their vegetative state are crucial, considering that abiotic stress conditions such as desiccation are not cues for synthesis of resistance forms such as spores (Potts, 1994). The extent to which survival of vegetative prokaryotes is possible at 
solid-air interfaces during prolonged periods of desiccation plays a significant role in both the natural environment and the pathogenesis of various disease causing microorganisms in clinical settings. Found at solid-air interfaces in indoor clinical environments such as operating rooms and outdoor environments such as soil, Gram-positive Arthrobacter spp. and the Gramnegative opportunistic pathogen Pseudomonas stutzeri are among relevant vegetative bacteria known for their desiccation tolerance and persistence (Lalucat et al., 2006).

Survival of bacteria is influenced by the supply of macro nutrients (Geets et al., 2006; Ferenci, 2007; Foladori et al., 2015), essential elements, and water (Potts, 1994; Reina-Bueno et al., 2012; Chodak et al., 2015); however, under stress conditions when the supply is scarce or diminished at solid-air interfaces, long-term and short-term management of these lifesupporting resources are governed by preservation and recycling for minimizing depletion and maintaining a larger carrying capacity for a microbial population. While there is a wealth of scientific research about microbial existence, persistence, and ecology at solid-aqueous environments, it is unclear whether cellular responses and population dynamics of vegetative bacteria at solid-air interfaces are similar with respect to their long-term survival. It has been reported by Johnson et al. (2007) that strong evidence suggests viable vegetative bacteria cells have survived up to half a million years in frozen samples showing evidence of a metabolically active state that allowed a degree of DNA maintenance.

This study investigated vegetative bacteria at solid-air interfaces to elucidate whether larger populations support higher carrying capacity for survivor cells that are in close proximity with their siblings, extending survival during prolonged periods of desiccation and nutrient starvation. Since the cell membrane serves as a barrier that separates the content of the cell from its surrounding environment, we expected that the intact inactive cells serve as potential long-term reservoirs of nutrients that can be accessed by the survivor cells when the 
population is faced with influx obstruction from the surrounding environment. Vegetative cells of Arthrobacter spp. and P. stutzeri were isolated from desiccated environments and selected to conduct survival experiments involving exposure of the cells to desiccation in absence of nutrients at glass-air interfaces. Direct microscopic observations of dried cells on the surface of glass indicate that the breakdown of the cell membrane did not occur immediately after death and desiccated cells remained intact in large clumps for months. We tested the hypothesis that different initial population densities would affect the survival rate (measured as viable and total cell counts). This hypothesis would support the idea that larger population sizes would support larger number of siblings in close proximity that might serve as reservoirs of nutrients, water, and essential elements to survivor cells. We then selected a population size that supports the survival of survivor cells to test the extent of survival in the presence of heatkilled, intact cells and homogenized cells at solid-air interfaces under desiccation with absence of nutrients. 


\subsection{Materials and Methods}

\subsubsection{Isolation and cultivation of bacteria from dry environments}

A Gram-negative bacterial strain was isolated from commercial Wyoming MX-80 bentonite (American Colloid Co). A Gram-positive bacterial strain was isolated from indoor air (Ronan et al., 2013).

\subsubsection{DNA extraction, PCR amplification, and DNA sequencing}

DNA was extracted using the MoBio UltraClean Soil DNA Extraction Kit (MoBio Laboratories INC., Carlsbad, CA, USA) as instructed by manufacturer protocols and the purified DNA was stored at $-20{ }^{\circ} \mathrm{C}$ until needed for PCR amplification. The bacteria-specific forward primers used for the $16 \mathrm{~S}$ rRNA PCR reaction were U341 F (5'CCTACGGGAGGCAGCAG-3') (Muyzer et al., 1993) and U758 R (5'CTACCAGGGTATCTAATCC-3’) (Baker et al., 2003) with target region V3-V4 (annealing conditions of $65-66^{\circ} \mathrm{C}$ per cycle and amplicon length of $435 \mathrm{bp}$ ). This primer pair amplifies a 418 base pair fragment (position 341 to 758 in the Escherichia coli 16S rDNA) (Muyzer et al., 1993). The protocol outlined by Yeung et al. (2011) was used for the PCR product quantification. DNA sequencing of the PCR products were performed at the Centre for Applied Genomics at SickKids in Toronto with an Applied Biosystems SOLiD 3.0 system. A single consensus sequence was generated from the forward and the reverse nucleotide sequences using BioEdit Sequence Alignment Editor (Version 7.0.9.0; Hall, 1999). NCBI database of $16 \mathrm{~S}$ rRNA sequences (http://blast.ncbi.nlm.nih.gov/Blast.cgi) was used to BLAST 
search the resulting consensus sequence followed by sequence alignment using Clustal W (http://www.ebi.ac.uk/clustalw/).

\subsubsection{Microbial population density and close proximity mediated survival analysis at solid air interfaces}

I) Surfaces and pure culture conditions. The Arthrobacter spp. and P. stutzeri were grown for 16-18 $\mathrm{h}$ in TSB (Tripticase soy broth $3 \mathrm{~g} / \mathrm{L}$ ) at room temperature with agitation. Supernatant from the bacterial suspension was removed after centrifugation at 8,000 RCF for five minutes and the remaining cell pellet was washed three times with sterile distilled water. The washed cell pellets were then resuspended to prepare three inocula corresponding to $1.4 \mathrm{x} 10^{7}, 3.8 \mathrm{x}$ $10^{6}$, and $2.6 \times 10^{5} \mathrm{CFU} / \mathrm{mL}$ for Arthrobacter spp. and $7.5 \times 10^{5}, 1.7 \times 10^{5}$ and $4.5 \times 10^{4} \mathrm{CFU} / \mathrm{mL}$ for P. stutzeri as determined by heterotrophic plate counts. Sterile microscope coverslips $(0.16$ $\mathrm{mm} \times 18 \mathrm{~mm} \times 18 \mathrm{~mm}$ (VWR International, USA)), serving as the inert non-porous surface for drying the bacterial cultures, were aseptically inoculated with $0.05 \mathrm{~mL}$ of the corresponding washed culture using the large drop inoculation method (Makison \& Swan, 2006; Ronan et al., 2013) and were allowed to dry for 6 hours. The coverslips were stored inside an adapted GasPak $^{\mathrm{TM}}$ chamber (Becton Dickson, Franklin Lakes, NJ) with controlled relative humidity $(\mathrm{RH})$ of $42 \pm 3 \%$ using a saturated magnesium chloride solution prepared as described by Greenspan (1977).

II) Enumeration of viable cells and total cell counts. At defined time points between 0 to 31 days, coverslips were transferred to sterile $50 \mathrm{~mL}$ conical centrifuge tubes (Sarstedt, Germany) containing $5 \mathrm{~mL}$ sterile $0.9 \%$ (w/v) $\mathrm{NaCl}$ and vortexed for one minute to remove the cells from the coverslip (Ronan et al., 2013). For viable counts, a serial dilution using sterile 
$0.9 \% \mathrm{NaCl}$ was prepared followed by spot plating onto TSA plates $(3 \mathrm{~g} / \mathrm{L})$ for each replicate and incubated at room temperature for $2-5$ days. The remaining volume was preserved at $4{ }^{\circ} \mathrm{C}$ after addition of formaldehyde $\left(C_{f}=2.0 \% \mathrm{v} / \mathrm{v}\right)$ and vortexing.

Total cell counts were performed using the preserved volume. In order to disperse the cells for direct enumeration, methanol $\left(C_{f}=1 \% \mathrm{v} / \mathrm{v}\right)$ was added to the suspension (Lunau et al., 2005) and the suspension was vortexed for 10 minutes. Contents were transferred to sterile 15 $\mathrm{mL}$ conical centrifuge tubes (Sarstedt, Germany), $0.5 \mu \mathrm{L}$ fluorescent nucleic acid gel stain SYBR $^{\circledR}$ gold $(10,000$ X Concentrate in DMSO; Thermo Fisher Scientific Inc., USA) was added to each tube, followed by vortexing and incubation in the dark for 20 minutes. A defined volume $(0.02 \mathrm{~mL}$ to $4.9 \mathrm{~mL})$ of the stained solution for each sample was vacuum filtered onto a black polycarbonate filter (pore size $=0.2 \mu \mathrm{m}, 25 \mathrm{~mm}$ diameter; Nuclepore, Whatman, VWR, Canada). A Nikon Eclipse 80i-C1 microscope (Nikon Instruments Inc., Canada) with Zeiss Axiovert 200M inverted epifluorescent and 60X oil immersion Plan Apochromat objective lens $(60 \mathrm{X} / 1.4 \mathrm{NA})$ was used for imaging 40 microscope fields per sample. CellC software $\left(\right.$ MATLAB $^{\circledR}$ source code, https://sites.google.com/site/cellcsoftware/) developed by Selinummi et al., (2005) was used for automated analysis of microscopy images for cell enumeration and measurement of cell morphological characteristics (volume, length, width).

III) Imaging. At each time point, duplicate coverslips were overlaid with approximately 20 $\mu \mathrm{L}$ of the fluorescent membrane stain $\mathrm{FM}^{\circledR} 1-43$ (Thermo Fisher Scientific Inc.,USA) at a working concentration of $5 \mu \mathrm{g} / \mathrm{mL}$ and incubated in dark for 20 minutes. A Nikon Eclipse 80i-C1 microscope (Nikon Instruments Inc., Canada) was used for acquiring epifluorescence images with mercury short arc $\mathrm{HBO}^{\mathrm{R}}$ (OSRAM GmbH, Germany) of the glass coverslips using the 60X/1.4 NA oil immersion Plan Apo objective. Image acquisition software TSView 
(7.1.1.2, Tucsen Imaging Technology Co. Ltd) was used to process the images at $0.62 \mu \mathrm{m} / \mathrm{px}$ and $1.1 \mathrm{z}$-step size.

\subsubsection{Evaluating the survival of a microbial population based on recycling of nutrients, water, and essential elements at solid air interfaces}

\section{I) Exposure of the live culture to dried intact heat-killed bacterial cells of the same species.}

\section{Live and heat-killed bacteria culture conditions:}

Arthrobacter spp. and P. stutzeri were grown for 16-18 h in TSB (3g/L) at room temperature with agitation. The bacterial suspension was washed three times with sterile distilled water with centrifugation at 8,000 RCF for five minutes between washing steps. The washed culture corresponded to $2.0 \times 10^{7} \mathrm{CFU} / \mathrm{mL}$ for Arthrobacter spp. and $2.1 \times 10^{4}$ for P. stutzeri. The total cell counts for the inoculum was done as described above. A portion of the washed culture was used for preparation of the heat-killed bacteria cultures. The Arthrobacter spp. cells were heat-killed at $75^{\circ} \mathrm{C}$ for 60 minutes and the P. stutzeri cells were heat-killed at $70^{\circ} \mathrm{C}$ for 60 minutes after which they were stored at $-80^{\circ} \mathrm{C}$.

The heat-killed culture was thawed and washed twice by centrifugation at 5,000 RCF for two minutes using sterile distilled water before co-inoculation with live cells. Microscopic confirmation was done to ensure that the cells remained intact after the heat-killing process. Five replicate samples confirmed that cells were indeed killed by the heating procedure mentioned above. Two treatments were prepared for each strain using a series of sterile cover glasses and large drop inoculation method. The first treatment served as the reference and involved addition of $0.1 \mathrm{~mL}$ sterile distilled water in a sterile environment and was allowed to dry for 6 hours. The second treatment was carried out by addition of $0.1 \mathrm{~mL}$ of the heat-killed 
suspension and was dried for 6 hours. Each cover glass for both treatments was then inoculated with $0.05 \mathrm{~mL}$ of the same washed live cell suspension and was allowed to dry for another 6 hours.

\section{II) Exposure of the live culture to dried homogenized cells of the same species.}

\section{Live and homogenized bacteria culture conditions:}

The Arthrobacter spp. was grown for 16-18 h in TSB (3g/L) at room temperature with agitation and the suspension was washed three times with sterile distilled water by centrifugation at 8,000 RCF for five minutes. The washed culture corresponded to $2.1 \times 10^{7} \mathrm{CFU} / \mathrm{mL}$. For the homogenized culture, Arthrobacter spp. was grown overnight and $500 \mathrm{~mL}$ of the cell suspension was concentrated to $26 \mathrm{ml}$ after 3 washing steps with sterile $0.9 \% \mathrm{NaCl}$ by centrifugation at 10,000 RCF for 20 minutes. The washed concentrated culture $(25 \mathrm{~mL})$ was homogenized with an Emulsiflex-05 homogenizer (Avestin, Canada) for three times at 2100-2500 psi. The homogenizer was washed with $0.9 \%(\mathrm{w} / \mathrm{v})$ saline bringing the final volume of the homogenized culture to $41 \mathrm{~mL}$. The homogenized culture was filtered twice through a GN-6 Metricel $^{\circledR}$ filter $(0.2 \mu \mathrm{m}$ pore size, Pall Corporation, Ann Arbor, MI) to sterilize the homogenate and remove larger particulates. To screen for the presence of viable cells in the filtered homogenate, five replicate samples of heterotrophic plate counts were done with incubation at room temperature for 3-5 days. Absence of intact cells was confirmed through microscopy for the post-filtered homogenized culture.

The experiment involved two treatments using a series of sterile coverslips for each treatment and large drop inoculation method in a sterile environment. The first treatment was carried out by inoculation of $0.1 \mathrm{~mL}$ of sterile distilled water, while $0.1 \mathrm{~mL}$ of the filtered homogenate was added for the second treatment group and all coverslips were allowed to dry for 6 hours. 
After the drying time, $0.05 \mathrm{~mL}$ of the washed live Arthrobacter spp. was inoculated on top of the dried drops of each coverslip and was allowed to dry for 6 hours.

III) Enumeration of viable cells and total cell counts. Both viable counts and total cell counts were carried out as described in the previous section for triplicate coverslips of each treatment at various time points.

\subsubsection{Statistical analysis}

Viable and total cell counts were transformed (natural log), resulting in linear relationships with time, in accord with the assumption that viable and total cell counts would decline with time following the model:

$\mathrm{C}_{\mathrm{t}}=\mathrm{C}_{0} \mathrm{e}^{-\mathrm{kt}}$

Where $C_{t}$ is the number of cells at a given time $(t)$, and $C_{0}$ is the initial number of cells. The slope of time versus natural logarithm-transformed cell counts describes $\mathrm{k}$, the first-order rate of decrease in viable (or total) cells in units of $\mathrm{d}^{-1}$. Differences among treatments (e.g. control versus heat-killed cells, different cell densities) were assessed using Analysis of Covariance (ANCOVA), with ln-transformed cell densities as the dependent variable, treatment as the independent variable, and time as a covariate. In this model, significant differences in the treatment $\mathrm{x}$ time interaction term indicate differences in decay rate $(\mathrm{k})$ between treatments, and therefore differences in survival of microbial populations. One-way Analysis of Variance (ANOVA) was used to assess the effects of treatment on morphology of cells (cell volume and length/width) at Day 31, expressed as percentages of morphological characteristics on Day 0. 
Statistical analyses were performed using SAS Enterprise (9.4). The obtained raw data can be found in Appendix C. 


\section{3 Results}

\subsubsection{Desiccated cells remain intact long after no viable counts are detected.}

Seeking evidence for existence of intact desiccated cells of P. stutzeri and Arthrobacter spp., we monitored three distinct starting population densities residing on the surface of glass coverslips (Figure 4). An increase in population density minimized the unoccupied space gaps for each bacteria population residing on the surface of the coverslip. The acquired images for all experimental time points are presented in Appendix B. 


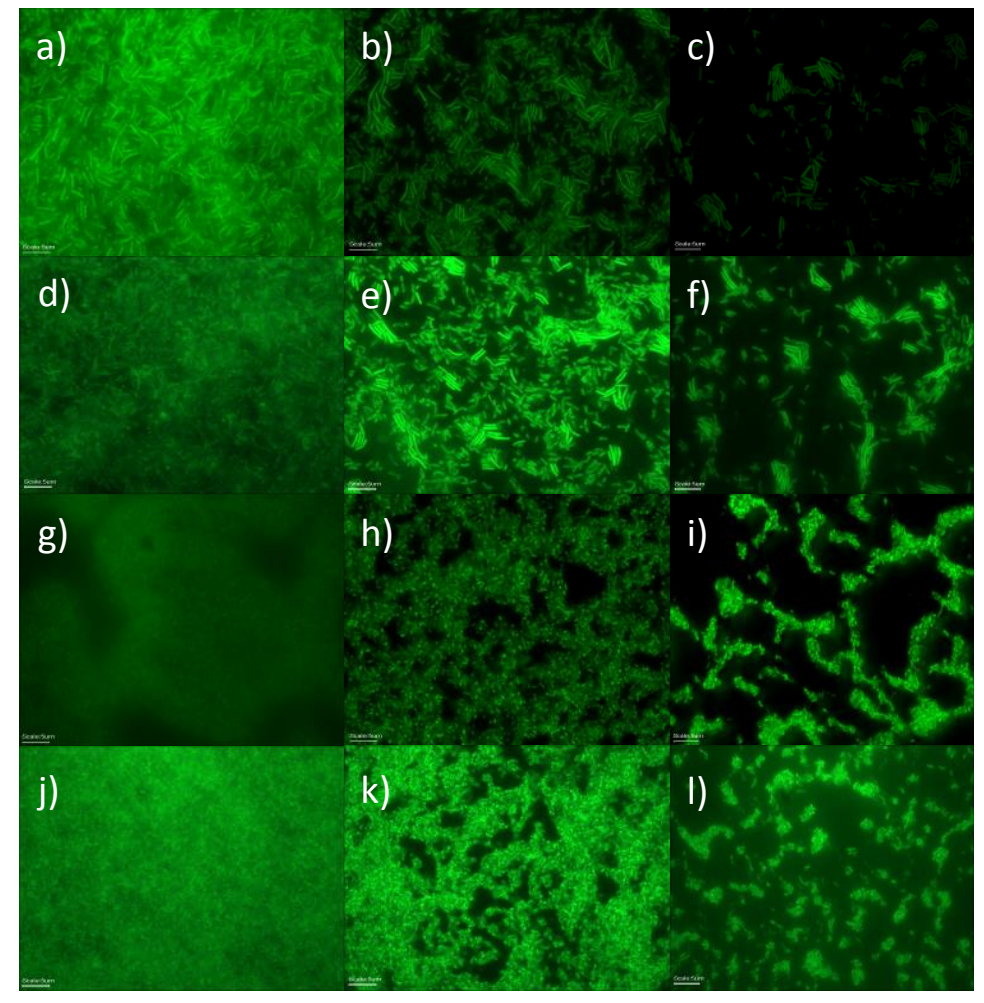

Figure 4. Monitoring existence of intact dried cells on the surface of glass coverslips by comparing three population densities of Gram-positive and Gram-negative bacteria populations.

a) P. stutzeri $7.5 \times 10^{5}$ (P. stutzeri Population 1) T0.25; b) P. stutzeri $1.7 \times 10^{5}$ (P. stutzeri Population 2) T0.25; c) P. stutzeri $4.5 \times 10^{4}$ (P. stutzeri Population 3) T0.25; d) P. stutzeri $7.5 \mathrm{X}$ $10^{5}$ (P. stutzeri Population 1) T28; e) P. stutzeri 1.7 X $10^{5}$ (P. stutzeri Population 2) T28; f) $P$. stutzeri $4.5 \times 10^{4}$ (P. stutzeri Population 3) T28; g) Artbrobacter spp. 1.4 X $10^{7}$ (Arthrobacter spp. Population 1) T0.25; h) Arthrobacter spp. $3.85 \times 10^{6}$ (Arthrobacter spp. Population 2) T0.25; i) Arthrobacter spp. 2.6 X $10^{5}$ (Arthrobacter spp. Population 3) T0.25; j) Arthrobacter spp. $1.4 \mathrm{X} 10^{7}$ (Arthrobacter spp. Population 1) T28; k) Arthrobacter spp. 3.85 X $10^{6}$ (Arthrobacter spp. Population 2) T28; 1) Arthrobacter spp. $2.6 \times 10^{5}$ (Arthrobacter spp. Population 3) T28. The RH was maintained at $42 \pm 3 \%$ for duration of the experiment, with exception of drying period (initial 3 hours at RH $60 \pm 5 \%$ ). Values at time 0 represent the initial viable cells in each population and $\mathrm{T}$ is measured in days. 
Direct microscopic observations of dried cells on the surface of glass indicate that the breakdown of the cell membrane did not occur immediately after loss of viability and desiccated cells remained intact in large connected clumps. The total cell counts of all three populations over time for both Gram-positive and Gram-negative bacteria of the same populations presented here confirmed that a large portion of their respective inoculums remained intact.

\subsubsection{Population density plays a role in survival of Gram-positive Arthrobacter spp. at glass-air interfaces.}

In all survival experiments, the viable counts of Artbrobacter spp. declined after drying over time on the surface of coverslips (Figure 5a). Highest survivorship was achieved by the largest inoculum density (Population 1), with loss of a member from this population taking longer than two days. This decay rate is significantly lower than the other two Arthrobacter spp. populations presented here indicating that differences in population densities influenced survivorship $\left(F_{2,26}=15.23, P=0.00004\right)$. The highest inoculum density population also remained viable for all experimental time points in absence of water and nutrients on the surface of glass coverslips at RH of $42 \pm 3 \%$.

Similarly, total cell counts declined over time for all population densities (Figure 5b). The decline in total cell numbers did not differ significantly among inoculation densities (Figure 5b; $\left.F_{2,32}=0.508, P=0.607\right)$. The cell density of the initial inoculum did affect the cell morphology of Arthrobacter spp. over time. Cell volumes on Day 31 were expressed as a change (in percentage) relative to initial cell volumes in the inoculum. Changes in cell volume varied as a

function of inoculum density, with low density (Population 3) demonstrating a 2-3 times increase in mean cell volume, while high density inoculum (Population 1) resulted in a decrease 
in mean cell volume (Figure $\left.5 \mathrm{c} ; F_{2,3}=14.49, P=0.029\right)$. Cells inoculated at lower density also tended to be more rounded than cells inoculated at higher density. Over 31 days, the length/width of cells inoculated at $1.40 \times 10^{7}$ cells / $\mathrm{mL}$ increased by approximately $12 \%$ relative to cells in the inoculum (Figure $5 \mathrm{~d} ; F_{2,3}=132.2, P=0.001$ ). 

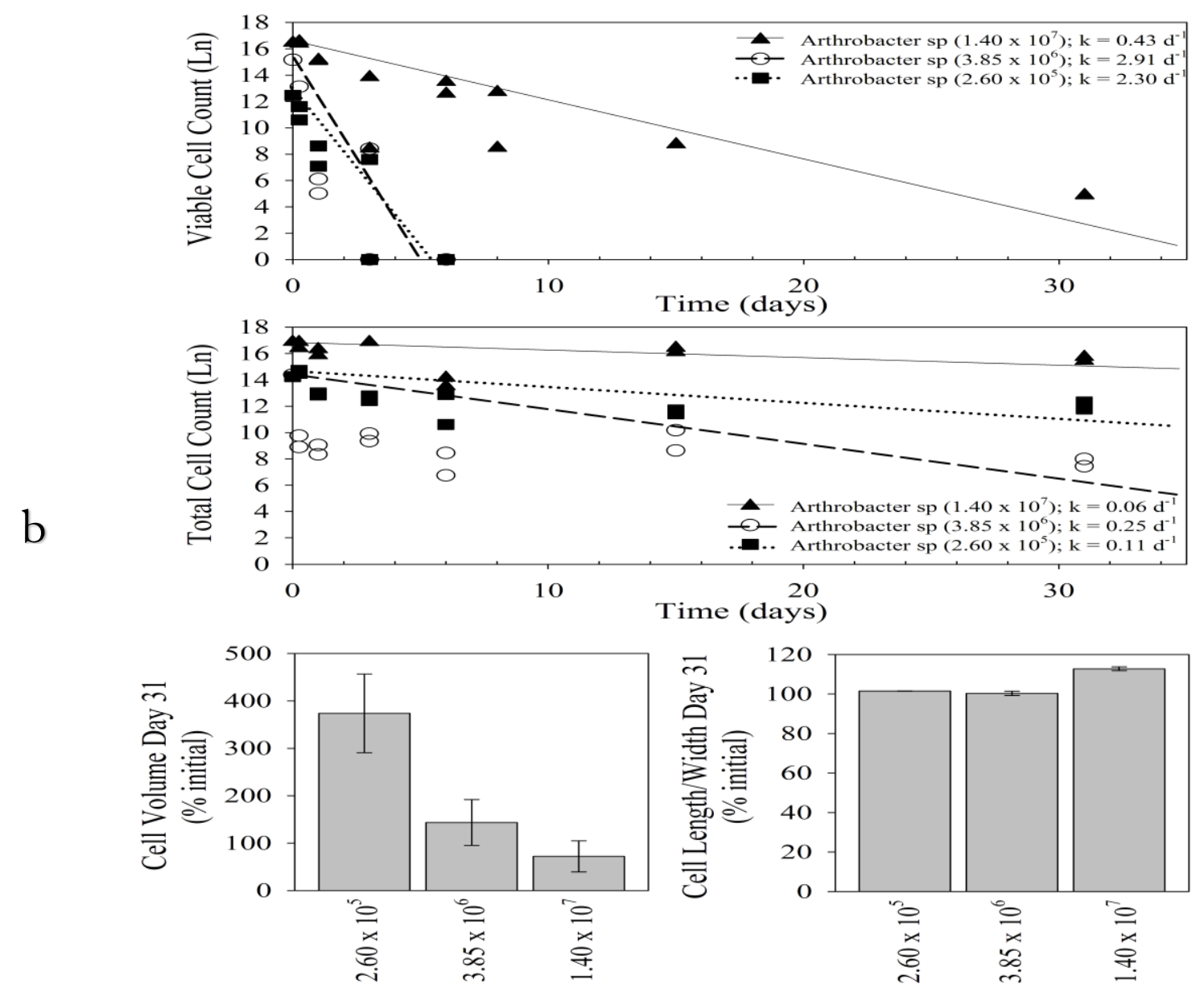

C

Figure 5. Higher population densities lead to better survival at solid-air interfaces. Arthrobacter spp. population density and close proximity mediated survival analysis at solid air interfaces.

a) Natural logarithm survival of viable Arthrobacter spp. bacteria at various initial population densities during desiccation on a glass substratum.: Population 1: $1.4 \times 10^{7}$ viable cells $/ \mathrm{mL}$; Population 2: 3.85 X $10^{6}$ cells $/ \mathrm{mL}$; Population 3: $2.60 \times 10^{5}$ cells $/ \mathrm{mL}$. b) Natural logarithm average total cell counts of dried Arthrobacter spp. bacteria (Population 1, Population 2, and Population3). The average volume of dried Arthrobacter spp. bacteria (Population 1, Population 2, and Population 3). The RH was maintained at $42 \pm 3 \%$ for duration of the experiment, with exception of drying period (initial 3 hours at $\mathrm{RH} 60 \pm 5 \%$. Values at time 0 represent the initial viable cells in each population and $\mathrm{T}$ is measured in hours. 


\subsubsection{Population density facilitated maintenance of intact Gram-negative $\boldsymbol{P}$. Stutzeri bacteria at glass-air interfaces without influencing viability.}

To determine whether population density facilitates maintenance of intact Gram-negative P. stutzeri bacteria at glass-air interfaces, viable and total cells were enumerated for 31 days. The population density of $P$. stutzeri cells did not effect their survivorship, as indicated by the change in viable cell counts over time across different inoculation densities with $F_{21,22}=1.670, P=0.31$ as illustrated in Figure 6a. Viable cell counts declined rapidly for all initial cell densities, and no viable cells remained after Day 1, regardless of inoculum density. Total cell numbers also declined over time (the calculated decay rate for the lowest density inoculum was slightly positive, but not statistically different from zero) (Figure 6b). The decline in total cell numbers did not differ significantly among inoculation densities (Figure $6 \mathrm{~b}, F_{2,31}=1.310, P=0.289$ ). Patterns observed for cell morphology as a function of inoculum density were similar to those observed with Artbrobacter spp. populations. At low inoculum density, average cell volume increased from Day 0 to Day 31, whereas average cell volume decreased over this time for the high inoculum density (Figure 6c). The change in cell length/width suggests that the cells at low inoculum density also became more rounded over time, while cells at high inoculum density became more elongated (Figure 6d). 

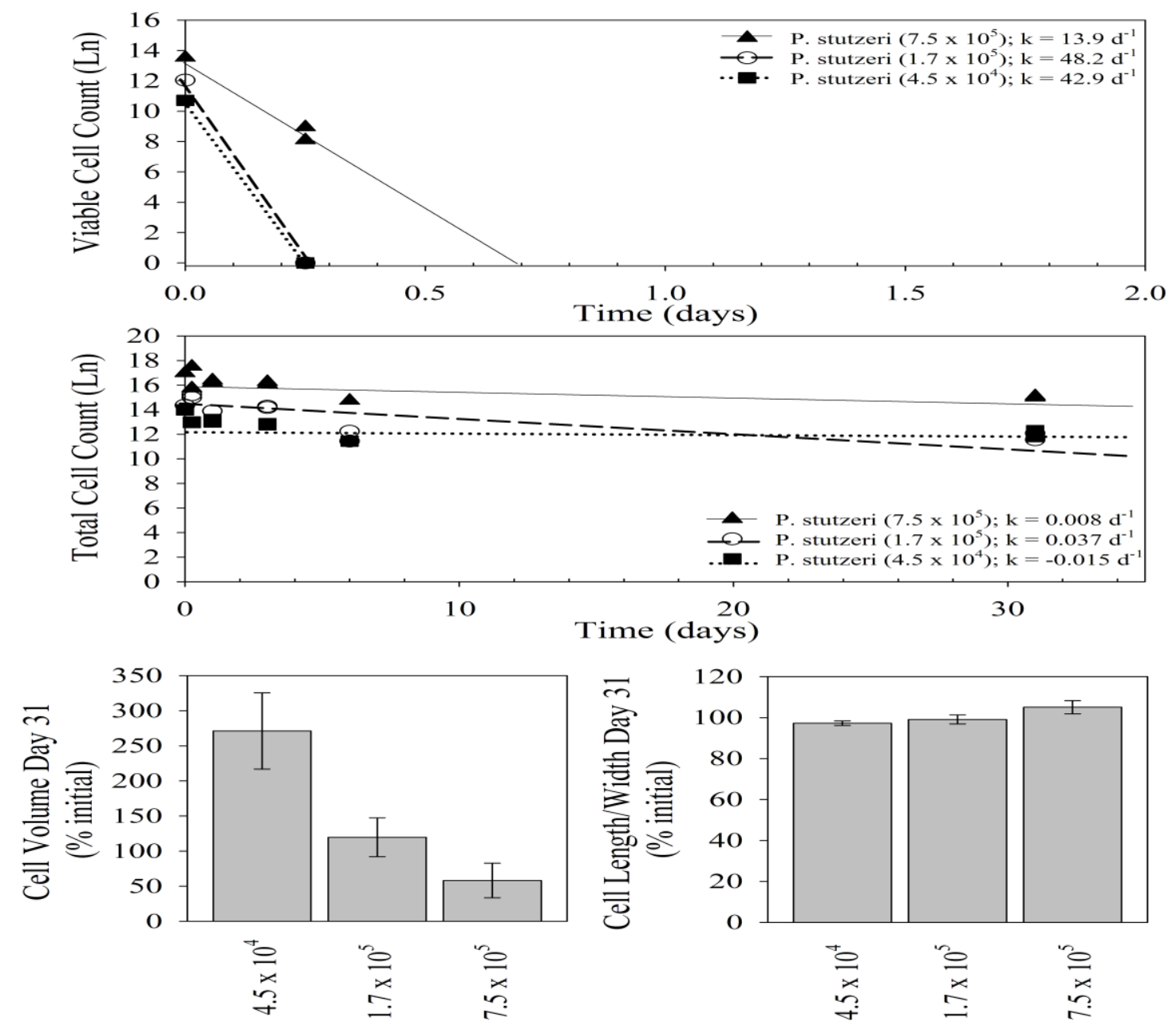

C

Figure 6. Higher population densities lead to increase in the number of intact cells at solidair interfaces. $P$. stutzeri population density and close proximity mediated survival analysis at solid air interfaces.

a) Natural logarithm survival of viable $P$. stutzeri bacteria at various initial population densities during desiccation on a glass substratum: Population 1: $7.5 \times 10^{5}$ viable cells $/ \mathrm{mL}$; Population 2: $1.7 \mathrm{X} 10^{5}$ cells/mL; Population 3: $4.5 \times 10^{4}$ cells/mL. b) Natural logarithm average total cell counts of dried $P$. stutzeri bacteria (Population 1, Population 2, and Population3). The average volume of dried P. stutzeri bacteria (Population 1, Population 2, and Population 3). The RH was maintained at $42 \pm 3 \%$ for duration of the experiment, with exception of drying period (initial 3 hours at RH $60 \pm 5 \%$. Values at time 0 represent the initial viable cells in each population and $\mathrm{T}$ is measured in days. 


\subsubsection{Presence of intact heat-killed cells of Arthrobacter spp. contributes to survival of desiccated Arthrobacter spp. cells during desiccation at glass-air interfaces over time.}

To determine whether the role of intact heat-killed cells of Arthrobacter spp. on survival of desiccated Arthrobacter spp. cells during desiccation, viable and total cells were enumerated for 31 days. Presence of intact heat-killed cells of Arthrobacter spp. enhanced survivorship, as indicated by the change in viable cell counts over time compared to the control group with $F_{1,40}=47.7, P<0.001$ as shown in Figure 7a. Viable cell counts declined rapidly after drying for both groups but the group exposed to heat killed cells retained viable cells for the duration of the experiment. A decline in total cell numbers over time was observed for both treatments as illustrated in Figure 7b. However, the decline in total cell numbers did not differ significantly among the treatments (Figure $7 \mathrm{~b}, F_{1,34}=0.58, P=0.45$ ). Patterns observed for cell morphology indicate that the average cell volume of the Arthrobacter spp. population exposed to heat-killed cells increased more significantly with $F_{1,34}=23.63, P=0.0083$ from Day 0 to Day 31 compared to the control treatment population (Figure 7c). The change in cell length/width suggests that there is no significant difference among the cells exposed to heat-killed cells and the control group (Figure 7d). 

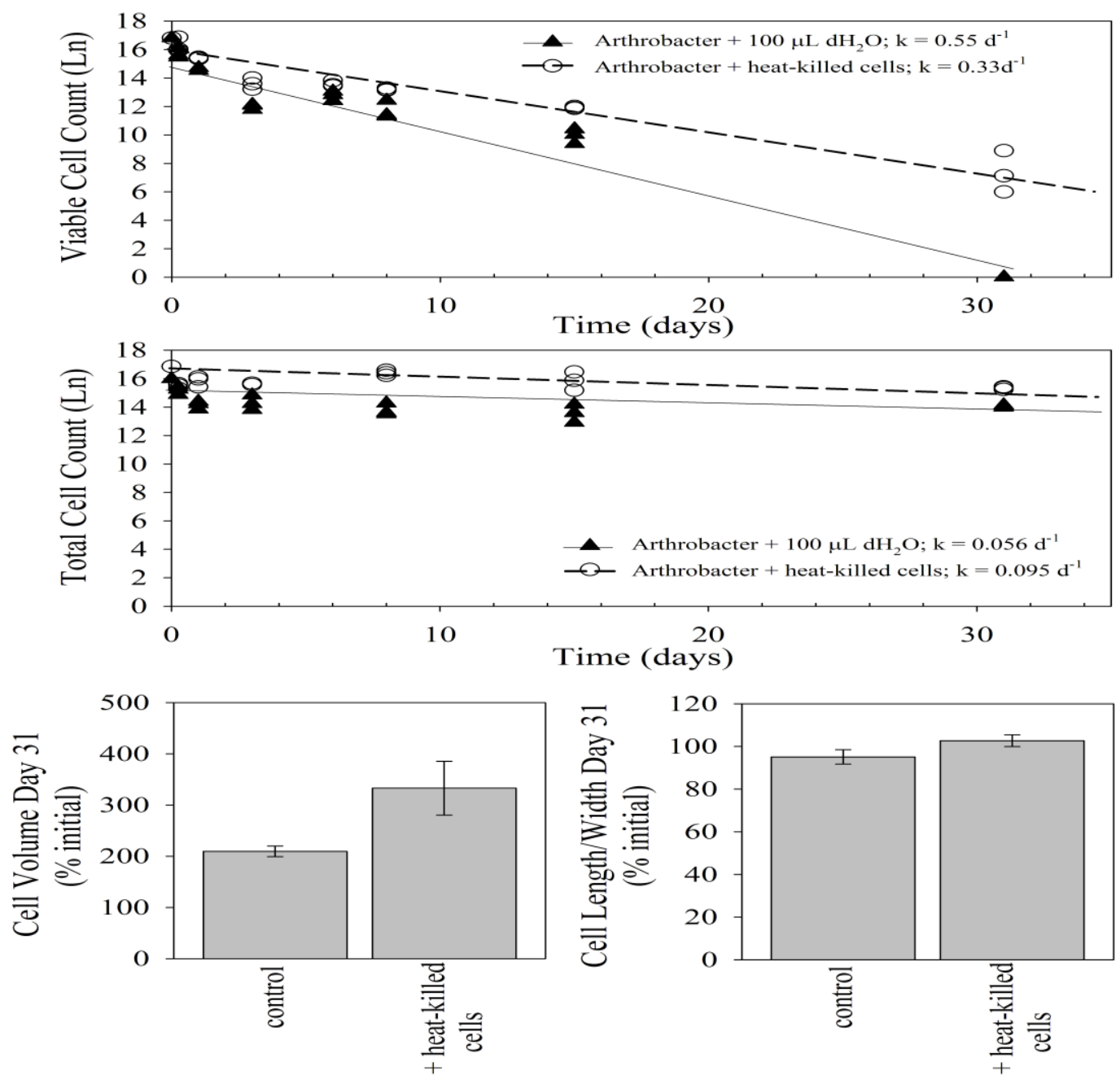

C

Figure 7. Presence of heat-killed cells enhances survivorship of Arthrobacter spp. cells under desiccation on a glass substratum over time.

A) Natural logarithm survival of dried Arthrobacter spp. survivor cells after treatment with distilled water and treatment with heat-killed Arthrobacter spp. cells. b) Natural logarithm average cell counts of dried Arthrobacter spp. after treatment with distilled water and with heat-killed Arthrobacter spp. cells. c) The average volume of dried Arthrobacter spp. cells after treatment with distilled water and treatment with heat-killed Arthrobacter spp. cells. d) Representative measurement of cell shapes by average cell length over average cell width values after treatment of Arthrobacter spp. cells with distilled water and treatment with heat-killed cells. The RH was maintained at $42 \pm 3 \%$ for duration of the experiment, with exception of drying period (initial 3 hours at RH $60 \pm 5 \%$. Values at time 0 represent the initial viable cells in each population and time is measured in days. 
Survivorship of P. stutzeri cells was enhanced by the presence of heat-killed cells, as indicated by the change in viable cell counts over time compared to the control group $\left(F_{1,23}=6.05, P=0.02\right)$, as shown in Figure 8a. Viable cell counts declined after drying for both groups, but a more rapid decline in viable counts was observed for the control group. Decline in total cell numbers over time was observed for both treatments as illustrated in Figure 8b. However, the decline in total cell numbers did not differ among the treatments (Figure 8b, $F_{1,31}=0.136, P=0.71$ ). Patterns observed for cell morphology indicate that the average cell volume from Day 0 to Day 31 and cell length/width did not vary for both populations of P. stutzeri. 

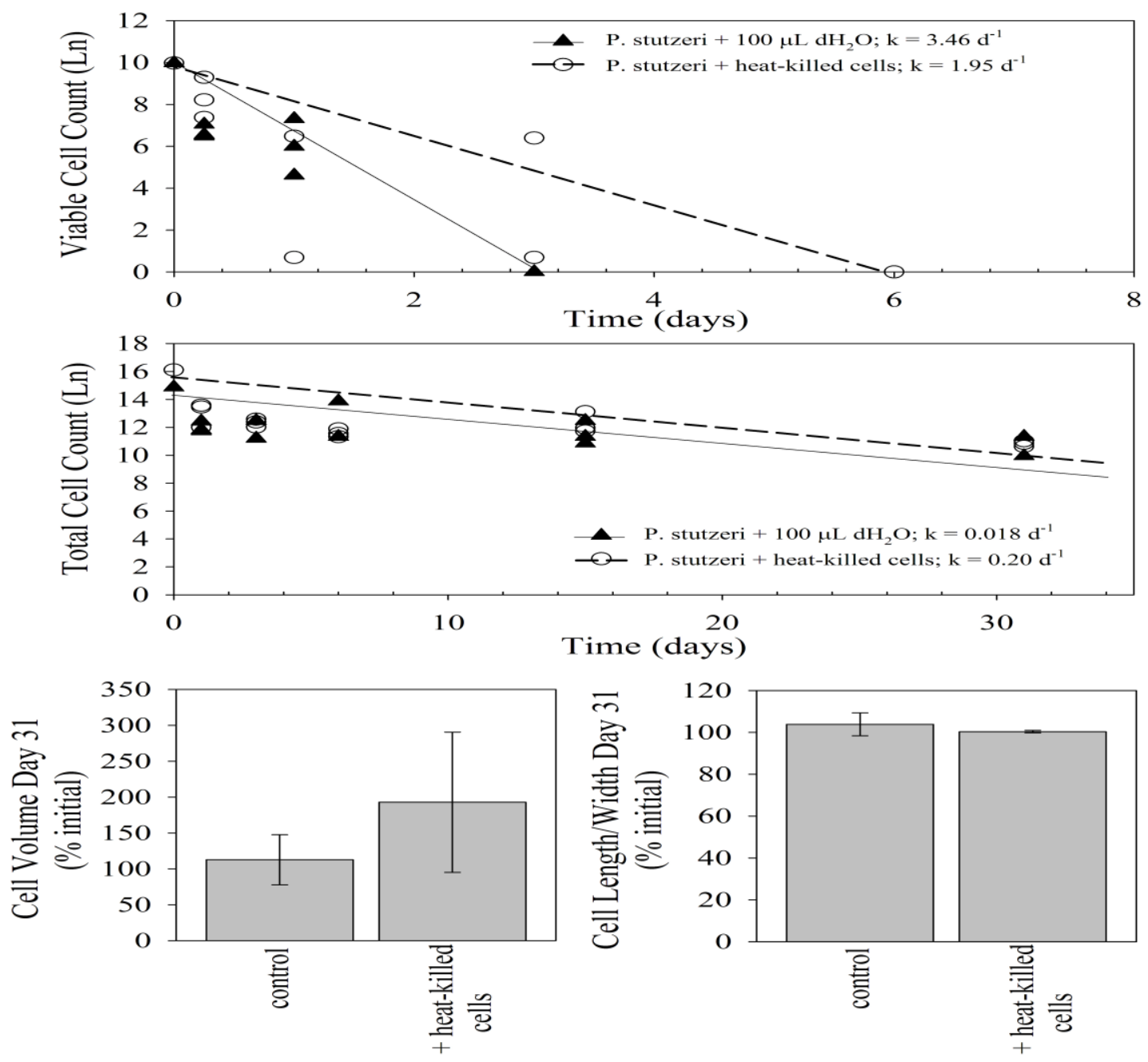

C

Figure 8. Presence of heat-killed cells enhances survivorship of $P$. stutzeri cells under desiccation on a glass substratum over time.

A) Natural logarithm survival of dried P. stutzeri survivor cells after treatment with distilled water and treatment with heat-killed $P$. stutzeri cells. b) Natural logarithm average cell counts of dried P. stutzeri after treatment with distilled water and with heat-killed $P$. stutzeri cells. c) The average volume of dried $P$. stutzeri cells after treatment with distilled water and treatment with heat-killed P. stutzeri cells. d) Representative measurement of cell shapes by average cell length over average cell width values after treatment of $P$. stutzeri cells with distilled water and treatment with heat-killed cells. The RH was maintained at $42 \pm 3 \%$ for duration of the experiment, with exception of drying period (initial 3 hours at RH $60 \pm 5 \%$. Values at time 0 represent the initial viable cells in each population and $\mathrm{T}$ is measured in days. 


\subsubsection{Presence of homogenized cells of Arthrobacter spp. enhances viability of desiccated Arthrobacter spp. cells during desiccation at glass-air interfaces over time.}

Presence of homogenized cells of Arthrobacter spp. enhanced survivorship, as indicated by the change in viable cell counts over time compared to the control group $\left(F_{1,38}=17.14, P=0.0002\right)$ as shown in Figure 9a. Viable cell counts declined rapidly after drying for both groups, although less rapidly for the population that was exposed to homogenized cells. Viable cells of Arthrobacter spp. exposed to homogenized counts were present for less than 20 days. A decline in total cell numbers over time was observed for both treatments as illustrated in Figure 9b. However, the decline in total cell numbers did not differ significantly among the treatments (Figure 9b, $F_{1,34}=1.76, P=0.19$ ). Patterns observed for cell morphology indicate that the average cell volume of the Arthrobacter spp. population exposed to homogenized cells increased by a greater amount than the control treatment population from Day 0 to Day $31\left(F_{1,4}=22.19, P=0.009\right.$; Figure $\left.9 c\right)$. The change in cell length/width suggests that there is no significant difference among the cells exposed to heat-killed cells and the control group (Figure 9d) with $F_{1,4}=12.59$ and $P=0.05$. 

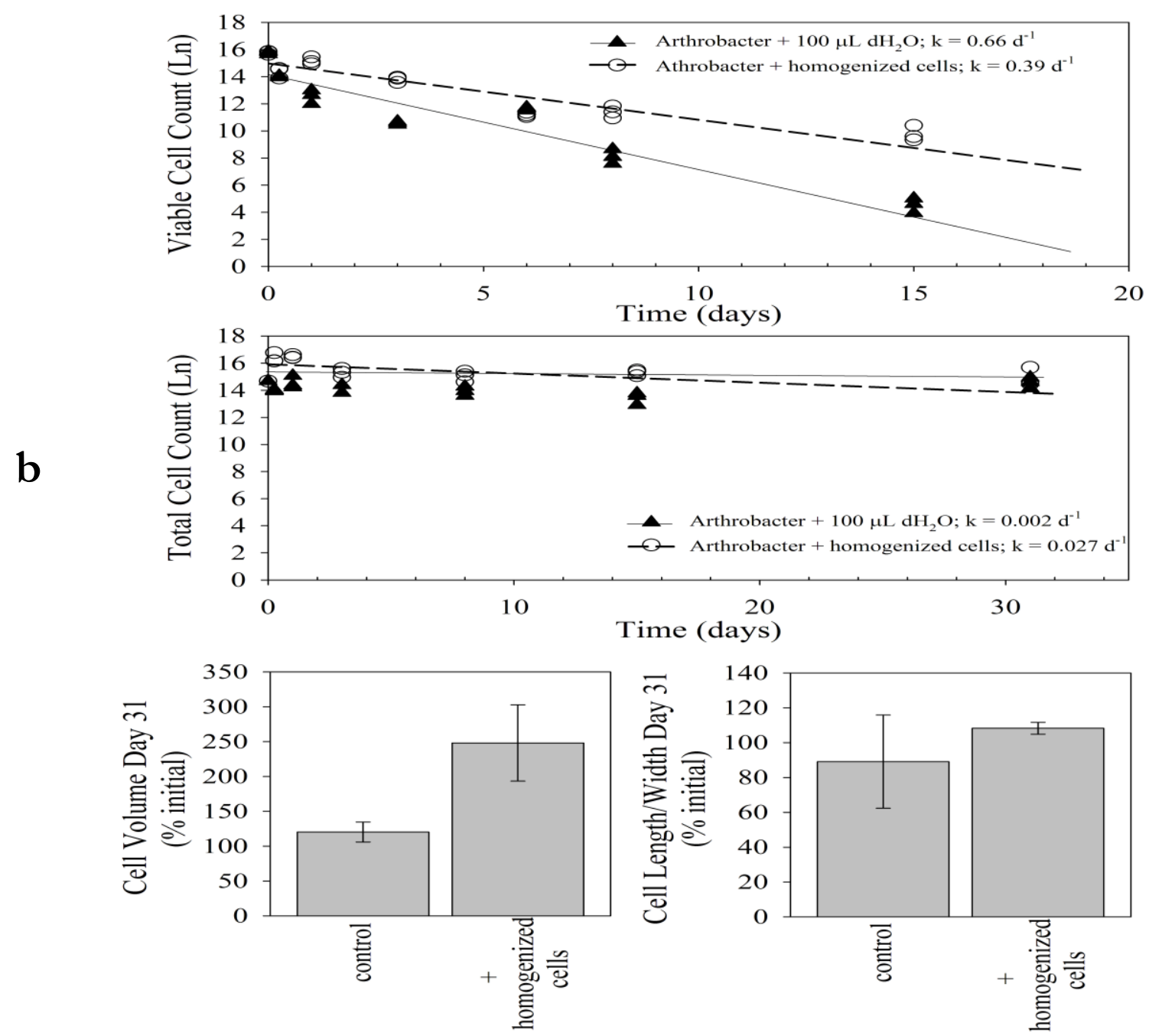

C

Figure 9. Presence of homogenized cells enhances the survival of Arthrobacter spp. cells under desiccation on a glass substratum over time.

I) Natural logarithm survival of dried Arthrobacter spp. survivor cells after treatment with distilled water and treatment with deposition of homogenized Arthrobacter spp. cell contents. II) Natural logarithm average total cell counts of dried Arthrobacter spp. after treatment with distilled water and treatment with deposition of homogenized Arthrobacter spp. cell contents. III) The average volume of dried Arthrobacter spp. cells after treatment with distilled water and treatment with deposition of homogenized Arthrobacter spp. cell contents. IV) Representative measurement of cell shapes by average cell length over average cell width values after treatment of Arthrobacter spp. cells with distilled water and treatment with deposition of homogenized Arthrobacter spp. cell contents. The RH was maintained at $42 \pm 4 \%$ after drying and the values at $\mathrm{T} 0$ represent the inoculum before drying and $\mathrm{T}$ is measured in days. 


\section{4 Discussion}

\subsubsection{Closeness of cells by bioflocculation enhances survival of prokaryotes under desiccation at solid-air interfaces by localizing the cells in close proximity to their siblings.}

At interfaces, bacteria have a propensity for adhering to solid surfaces (Teschler et al., 2015; Li et al., 2012; Logan and Hunt, 1988; Busch and Stumm, 1968) and to each other by self-association to form aggregates referred to as bioflocculation (Teschler et al., 2015; Logan and Hunt, 1988; Busch and Stumm, 1968). Bioflocculation results from bridges between adjacent cells by polymeric extracellular or cell-surface materials such as polymeric carbohydrates containing anionic and non-ionic functional groups (i.e. -COO- and -OH groups) (Busch and Stumm, 1968; Harris and Mitchell, 1973; Tenny and Verhoff, 1973; Dierdonck et al., 2013), extracellular polymeric substances (EPS) (Xie et al., 2010; Tsuneda et al., 2003; Pavoni et al., 1972), cations (Sobeck and Higgins, 2002; Treweek et al., 1979, Tenny and Verhoff, 1973), hydrophobic interactions (Urbain et al., 1993; Van Loosdrecht et al., 1987; Dahlback et al, 1981), and charged neutralized by Dejaguin-Landau-Verweg-Overbeek (DLVO-) interactions (Ndikubwimana et al., 2015; Liu et al., 2007; Wilen et al., 2003; Azeredo et al., 1999). At solid-air interfaces, bioflocculation most likely takes place prior to desiccation due to considerable limitations with mobility of bacteria in absence of aqueous media at low $\mathrm{RH}$ environments. The main advantage for bacteria populations offered by bioflocculation prior to drying is then the spatial arrangement of cells on surfaces when they dry on the surface relative to each other, since cells are localized in close proximity to one another. The present study suggests that larger population densities support formation of more extensive connected clumps that remain intact and connected at solid-air interfaces after drying (Figure 4), regardless of the viability status of the siblings, providing the members with a unique advantage for survivorship. This hypothesis was further supported by the 
significant differences among the viability of three population sizes of Arthrobacter spp. (Figure 5) and $P$. stutzeri bacteria (Figure 6) over time.

When cells were in close proximity to one another, the population dynamic governed the individual cellular response of the members to desiccation in absence of nutrients. As indicated by viability counts, a portion of the larger population for both Arthrobacter spp. (Figure 5) and P. stutzeri (Figure 6) bacteria resumed to metabolic active state when plated, whereas smaller populations of either species lost viability. The high population density (Population 1) of both Gram-positive Arthrobacter spp. and Gram-negative P. stutzeri resulted in lower cell volumes and rod-shaped cells, whereas low population densities had cells with greater average cell volume and rounded cells, decreasing surface area relative to volume. Hence, survival of vegetative bacteria at solid-air interfaces seems to be extended beyond the cellular response mechanism of an individual bacterium and might be dependent on population density.

Indirect responses to complex population based interactions among a mixed bacterial community such as predation and competition due to environmental stresses have been reported and can make this process selective toward survival of survivor cells at the expense of other members. For example, diverse groups of epiphytic bacteria inhabit and grow on the dry surface of leaves that are identified to inhabit surfaces in aggregates (Morris et al., 1998; Monier and Lindow, 2003; Monier and Lindow, 2004; Jacques et al., 2005). Biological disadvantages of bioflocculation were reported by Monier and Lindow (2005) when they observed significantly higher proportions of dead cells $(13.2 \pm 8.2 \%$ compared to monospecific $1.6 \pm 0.7 \%$ ) in mixed aggregates of Pseudomonas syringae and Pantoea agglomerans at leaf surfaces suggesting complicated biological interactions among a mixed bacterial community. Nevertheless, the benefits of bioflocculation at solid-air interfaces were reported for aggregated P. syringae (B728 strain with GFP marker) on the surface of bean leaf periodically exposed 
to desiccation stress compared to solitary cells by higher viability rates (Monier, 2002; Monier and Lindow 2003).

\subsubsection{Survivors need saviours: vegetative bacteria survive as a community rather than individuals.}

In nature population heterogeneity is dominant (Hoffmann et al., 1999; Dabnau and Losick, 2006), ultimately allowing surviving cells to shape the dominant morphology of a new population when environmental stresses arise. Reliable viability measures that were taken on air-dried bacteria on the surface of glass after drying suggest that our data supports population heterogeneity and not all cells in a population respond in a similar manner to water deficit in the absence of nutrients at solid-air interfaces. Maintaining a persistent state is an ancient adaptation of prokaryotes for conquering diverse habitats and surviving alterations that occur in nature. At solid-air interfaces lack of water imposes significant challenges at the cellular level including but not limited to disturbing the progression of reaction mechanisms by enzymes (Potts, 1994; Potts, 1999), structural order of cells (Potts, 1994; Potts, 2005), stability of proteins (Fredrickson et al., 2008; Potts, 1994), DNA (Mattimore and Battista, 1996; Potts, 1994), and lipids (Singh et al., 2002; Potts, 1994); thus survival entails considerable selective pressure toward the fitness of individuals that survive and requires additional support from the community to extend and benefit from shared survival means beyond the boundaries of a cell. There are many forms of selective community dependent survivorship that benefits a bacterial population such as biofilm formation for collective defense (Hall-Stoodley et al., 2004; Donlan and Costerton, 2002; Costerton et al., 1978), selfish and altuistics populations (Carmona-Fontaine and Xavier, 2012; Keymer et al., 2008), bacterial persisters (Dawson, 2011; Lewis, 2005; Bigger, 1944), bacterial cheaters (Yurtsev et al., 2013; Hibbing et al., 2010; Valicer, 2003), cannibalism (Rozen et al, 2009; Calverys and Havarstein, 2007), and programmed cell death (Allocati et al., 2015; Nystrom, 
2003; Chaloupka and Vinter, 1996). In all instances survival cannot be extended to all members of the population and the portion of the population that dies contributes to both survival and characteristics defining the surviving portion of the population. The extent and duration of desiccation and absence of nutrients determines the carrying capacity for the number of individuals that can be supported within a population. Larger proportion of survived cells within the population were enumerated in the highest inoculum populations of Arthrobacter spp. and P. stutzeri, where bacterial cells were in close proximity with each other based on direct microscopic observation of the cells on the surface of glass (Figure 4), and relative viable to total counts (Figure 5 and Figure 6). Interestingly, the same inoculum culture was used to achieve 3 different population sizes and yet the viability of the members was greatly influenced based on population size. The carrying capacity for each population was influenced by population size for both Gram-positive Arthrobacter spp. and Gram-negative P. stutzeri. A bacterial cell from Population 1 (highest population density) is likely to be surrounded by a larger number of siblings compared to a bacterial cell from Population 3 (lowest population density). We found that population size plays a significant role by localizing cells in close proximity to their siblings. We were unable to get viable counts for population sizes smaller than $10^{2} \mathrm{CFU} / \mathrm{mL}$ immediately after drying and the data was excluded. It was not known if lack of viable counts was associated with laboratory conditions, limitations with physical and chemical components that were utilized for homogenization of cells, or biological cues released by dead lysed cells. In addition to the physical and chemical properties of the environment that surrounds bacteria populations at solid-air interfaces, the population dynamic is also subject to intraspecific interactions among the members of the same species (among siblings in this study) or perhaps more complicated interspecific interactions with another microbial community in natural environments. 
A study by Mendelson et al. (2004) provided evidence that self-assembly and joining fibers allowed $B$. subtilis cells to form multiclonal aggregates that moved over solid surfaces and dragged other structures referred to as "cargo" over solid surfaces. A combination of heterogeneity and the immediate environment of the bacteria can offer an additional benefit to a bacterial community and that is not all cells within a population will die and degrade at the same time. This study shows that the total cell counts of intact bacteria are more stable than viable counts and there was no significant difference among total number of cells that were lost per day for the three different population sizes of Arthrobacter spp. and P. stutzeri. The slow decay rate for total bacteria at solid-air interfaces seems to be independent from population size indicating that slow loss of intact cells can be an ancient mode of survival for prokaryotes based on the composition of their cell membrane. Our data suggests that survival of intact cells was extended to a large portion of the population and was maintained long after viable counts diminished. The intact 'zombielike' cells were not responsive to culture base techniques for determination of viability and would have remained undetected and lifeless if not investigated.

\subsubsection{A bacterial community relies on huddled zombielike cells that recycle and preserve nutrients, water, and essential elements at solid-air interfaces to survive.}

The survival mode seems to place bacteria in a borderline state between living and dead with longevity relying on complex interactions of cell with its biotic (intra- and potentially inter-specific) and abiotic (cells' immediate surrounding) environment. The zombielike intact cells demonstrate low rate of cell loss over time and slower decrease in viability measures for higher population density (Population 1, Figure 5 and Figure 6) might be associated with larger number of zombielike intact cells in close proximity of viable survivor cells. Survival might then be associated with preservation of nutrients, essential elements, and water necessary for low metabolic activities of the cells. For example, investigating population size of Pseudomonas fluorescens A506 during and after colonization on the solid 
surface of the snap bean plants, Marcier and Lindow (2000) suggested that availability of carbohydrates did not limit bacterial growth when they entered death phase. They noted that carbohydrates were not exhausted but decreased to reach a steady state at about $25-40 \%$ of initial amounts (Mercier and Lindow, 2000). The zombielike intact cells either serve as long term reservoirs that supply survivor cells overtime or revive to higher metabolic states.

Data collected from survival of extremophiles in the McMurdo Dry Valleys of Antarctica suggested that bacteria formed high-density aggregates in all of the lakes screened. Additionally, aggregates were comprised of active, dead, and lysed microbes allowing cycling of nutrients by creating microenvironments with increased concentrations of complex nutrients slowly released and extracted from the matrix, supporting survival during winter months in the absence of primary activity in the lake (Lisle and Priscu, 2002). At aqueous environments, a condition referred to as "cryptic growth" has been described for starved microbial populations in death (or decline) phase, where the portion of dead bacteria support viability of $2-4 \%$ of the population (Roszak, 1987). In agreement with cryptic growth observations, our data suggests that presence of dead cells (heat-killed Figure 7 and Figure 8 or homogenized Figure 9) enhances viability of bacteria at solid-air interfaces under desiccation and nutrient starvation. No data was reported for P. stutzeri cells that were exposed to homogenized cells because we were unable to obtained any viable counts for all time points starting with immediate counts after drying. It is not known if the cells were viable but non-culturable (VBNC) at this stage or if they were responding to potential chemical cues released by lysed P. stutzeri cells. Presence of homogenized cells extended relative viability of Arthrobacter spp. cells for up to 20 days; while exposure to heat-killed cells allowed Arthrobacter spp. cells to remain viable throughout the duration of the experiment (more than 31 days) under low RH (42 $\pm 4 \%)$. It seems that presence of heat-killed cells (Figure 7 and Figure 8) enhances long term survival of survivor cells, as the nutrients and water 
content of the cells will be preserved inside the intact inactive cells until the cell membrane is lysed over time. Thus, the Artbrobacter spp. cells that are exposed to lysed homogenized cells (Figure 9) benefit from additional nutrients during drying. However, the viable cells have no access to the limited water content of the cells over time, since the content of homogenized cells shortly before drying of the cells took place.

It was previously reported that starving bacteria in aqueous environments adjust their morphology to survive by appropriate physiological response. One of the major observations is decrease in cell volume referred to as "round body" phenomenon (Roszak and Colwell, 1987). Carlucci (1974) suggested that small rounded cells are considered as "normal" morphological and physiological state in the nutrient limited environments such as the open ocean, where concentrations of organic carbon per liter are in the microgram per litre scale. We monitored the morphological responses of bacterial cells to desiccation in each population. Our results suggest that cells in lower population density (Population 3) for Arthrobacter spp. and P. stutzeri formed round bodies with higher mean cell volumes (Figure 5 and Figure 6). The cells in our higher population density (Population 1) were more elongated and had lower mean cell volume possibly because the cells in Population 1 with their siblings in close proximity did not face the same extent of nutrient deprivation as Population 3. No significant changes in total cell numbers were reported among the groups that were exposed to dead cells compared to the control groups. The Arthrobacter spp. cells that were exposed to heat-killed cells (Figure 7) and homogenized cells (Figure 9) significantly increased in mean cell volume but no rounded bodies were formed. Considering selection of small population size was avoided prior to conducting the experiments, it is possible that the rounded body phenomenon is a selective cellular response that is affected by population dynamics. No changes in morphology for P. stutzeri cells were observed based on our data comparing the control group with P. stutzeri cells exposed to heat-killed cells (Figure 8) 
suggesting that the extent of morphological adjustments can additionally be specific to a particular species in accordance with the isolation condition that defines the immediate environment of the cell. 


\subsection{Conclusions}

Gaining insights about how cells access resources to maintain their low-level cellular activities at solid air interfaces in the absence of nutrients provides valuable information for devising control measures for bacteria populations for bio-containment and bio-control purposes in natural environments, for minimizing the role of inanimate surfaces in transmission of nosocomial infections in clinical settings, and for manipulating the shelf life of target bacteria at solid-air interfaces.

It appears that long-term survival of bacteria under desiccation with absence of nutrients depends on the carrying capacity for the microbial population, which is the maximum bacteria population size that is sustained and supported at solid-air interfaces based on the sum of the amount of nutrients, essential elements, and water that is preserved and available to a microbial community. Other than cellular response mechanisms that a species is equipped with, population dynamics also influence this carrying capacity. Population size and localization of cells at solid-air interfaces in close proximity to their siblings might influence population dynamics for survival under desiccation by allowing access for collective survivorship. We envision that more accurate measures for targeting intact cells rather than reliance on culturable viable counts along with gaining knowledge about the target microbial population instead of restricting the analysis on isolated individual cells will reduce errors in microbial survival analysis and especially for detection of vegetative bacteria. 
4 SEARCHING FOR BACTERIA IN STICKY SITUATIONS:

METHODS FOR INVESTIGATING BACTERIAL SURVIVAL AT SOLID-AIR INTERFACES INVOLVING WYOMING MX-80

BENTONITE 


\section{1 Introduction}

A major concern for the future of nuclear power generation is permanent disposal, as well as longterm management of highly radioactive waste generated by the power plants (Kremer et al., 2009). Compacted Wyoming MX-80 bentonite (bentonite) blocks are considered to create low permeable zones, with high sorption capacity for water and low hydraulic conductivity to isolate and seal used nuclear fuel for the Canadian vault design (Johnson et al., 1994; Karnland et al., 2006; NWMO, 2011). An inherent challenge is to evaluate the potential influence of microbial survival and activity on the overall performance and integrity of a vault, the near field engineered excavation (consisting of backfill materials, bentonite buffer, used fuel containers) as part of safety assessment and for designing prediction models (Wolfaardt and Kober, 2012).

Bentonites have been commonly used in civil and hydraulic engineering for containment of waste deposits, for sealing purposes including landfill and foundation dike construction and by other industries as clarifying and adsorbing agents (Koch, 2002; Montes-H and Gerard, 2004; Montes-H et al., 2005). The Wyoming montmorillonite-based clays occur as layers in marine shales and MX-80 material is a blend of various sodium dominated bentonite horizons (Karnland et al., 2006). Studies suggest that pure bentonite offers sufficient prokaryotic population density reduction when compacted to $2 \mathrm{Mg} / \mathrm{m}^{-3}$ that is water saturated to $26 \% \mathrm{v} / \mathrm{w}\left(\mathrm{a}_{\mathrm{w}}\right.$ of 0.96 ) by significantly lowering water availability for prokaryotic activities (Stroes-Gascoyne and Hamon, 2007). The prevailing conditions in vaults using bentonite barriers would be expected to limit prokaryotic population density and activity due to low water activity $\left(\mathrm{a}_{\mathrm{w}}\right)$, high initial temperature, radioactive decay, and constrained spaces due to the small pore size. Considering the hostile conditions, the prime concern for a microbial community is survival and persistence in the bentonite clay's distinct macro- and microenvironment. Thus, 
compaction of bentonite clay materials impairs microbial mobility and limits diffusional patterns for external water and nutrients, making the interfaces involving bentonite potentially preferential for microbial survival including interfaces formed as result of crack formation due to desiccation of the clay barrier (Stroes-Gascoyne \& West, 1997). Interfaces formed by cracking as the clay barrier becomes desiccated may provide refuge where bacteria may survive. If the conditions change over time in the future (e.g. delivery of water), these are potential hotspot sites for enhanced microbial activity and sites of vulnerability due to production of metabolic byproducts. Despite a wealth of information on bacterial survival in aqueous-solid interfaces, very little is known about survival of bacteria under unsaturated solid-air interfaces.

Significant advances in prediction modeling of chemical, thermo-hydrological and physical processes that are involved for long-term containment of a vault have been made. In contrast the role of microbial survival and activity and its potential impact requires further assessment considering the complexity of the in situ environment and biological processes involved. In order to assess microbial survival at bentonite-air interfaces, effective measures are required to establish a coherent conceptual framework that is suitable for the complexity of microbial interactions with their physical environment. The main purpose of this study is therefore to present a suitable method for evaluating microbial survival during desiccation at bentonite-air interfaces using bacteria species that are relevant to an indigenous bentonite community. Here we define desiccation as removal of substantial amount of water from bacterial cells by matric stress where the cell membrane is exposed to the atmosphere (gas phase). This is in contrast to osmotic stress where the $\mathrm{a}_{\mathrm{w}}$ of the cell bathed in an aqueous solution is diminished (Potts, 1994). We begin by characterizing ten isolated bacterial strains from the bentonite and examining their survival on inert glass substrata during desiccation with lack of nutrient availability. Effective bacterial cell removal steps from complex porous solid surfaces are required, in order to transfer and remove bacterial cells effectively for enumeration purposes and survival analysis. 
Clay minerals montmorillonite bentonite materials have high capacity for binding to biopolymers such as proteins and nucleic acids DNA and RNA, with the strength of this binding dependent on the cation concentration $\left(\mathrm{Na}^{+}\right.$and $\left.\mathrm{MG}^{2+}\right), \mathrm{pH}$, and the absolute temperature of their medium (Beall et al., 2009; Lorenz and Wackernagel, 1992; Lavie and Stotzky, 1986; Fraenkel-Conrat et al., 1969; Blanton and Barnett, 1969). Mutual sorption between various clays and bacterial cells increases respectively according to: montmorillonite < vermiculite (illite) < kaolinite (in order of decreasing negative charge), while DNA adsorption follows in order of montmorillonite $>$ fine inorganic clay $>$ fine organic clay $>$ kaolinite (Theng et al., 1995; Cai et al., 2006). There is greater emphasis on the use of culture dependent methods for microbial studies involving bentonite clays stemming from the challenges that are present for molecular based techniques due to formation of strongly bound bentonite clay-DNA complexes. The focus of our paper is primarily on examining bacteria survival under desiccation and effective removal of bacteria cells from bentonite material for assessment of survival using culture dependent techniques but some concepts can be applicable to other microbial survival assessments at solid-air interfaces. 


\subsection{Materials and methods}

\subsubsection{Isolation of cultivable aerobic bacteria from Wyoming MX-80 bentonite}

Aerobic indigenous bentonite bacteria were isolated from commercially purchased Wyoming MX-80 bentonite clays (bentonite) (American Colloid Co). A total of 10 isolates were selected based on their morphotypes. From the 10 selected isolates, eight unique colonies were picked from tryptic soy agar (TSA) plates $\left(3 \mathrm{gL}^{-1}\right)$ (EMD Chemicals Inc., Mississauga, ON, Canada) and two isolates were picked from Reasoner's 2A agar (R2A) (Sigma-Aldrich Canada Co, Oakville, Canada) that had been prepared by vortexing $1 \mathrm{~g}$ of bentonite in $10 \mathrm{~mL}$ of sterile distilled water using the spread plate technique and incubation at room temperature for 3 days. The selected colonies were transferred to TSA $\left(3 \mathrm{gL}^{-1}\right)$ plates by streaking. The pure culture of each isolated strain was used after 3 days for cryopreservation, extraction of genomic DNA, PCR amplification of $16 \mathrm{~S}$ rRNA followed by sequencing and phylogenetic analysis.

\subsubsection{Characterization of cultivable aerobic bacteria from bentonite}

\section{I) Extraction and amplification.}

Colonies isolated from bentonite were grown overnight in TSB $\left(3 \mathrm{~g} \mathrm{~L}^{-1}\right)$ followed by genomic DNA extraction using the MoBio UltraClean Soil DNA Extraction Kit (MoBio Laboratories Inc., Carlsbad, CA, USA) as instructed by manufacturer's protocols. Extracted DNA was stored at $-20^{\circ} \mathrm{C}$ until needed. The 16S rRNA gene of each isolate was amplified for sequencing. Bacteria-specific primers used for the 16S rRNA PCR reaction were forward primer U341 F (5'-CCTACGGGAGGCAGCAG3’) (Muyzer et al., 1993) and reverse primer U803 R (5'-CTACCAGGGTATCTAATCC-3') (Baker et 
al., 2003) (Centre for Applied Genomics at SickKids, Toronto). Each PCR reaction totaled $50 \mu \mathrm{L}$ containing $1 \mu \mathrm{L}$ of genomic DNA ( $50 \mathrm{ng}$ ), $25 \mathrm{pmol}$ of each primer, $6.875 \mu \mathrm{g}$ BSA, $800 \mu \mathrm{M}$ dNTPs (200 $\mu \mathrm{M}$ from each), Taq buffer (10 mM Tris- $\mathrm{HCl} \mathrm{pH} 9.0,50 \mathrm{mM} \mathrm{KCl,} 1.5 \mathrm{mM} \mathrm{MgCl}$ ) with 2.5 units Taq (New England BioLabs, Pickering, ON, Canada) (Yeung et al., 2011). Reaction tubes were kept on ice during the procedure (New England BioLabs, Pickering, ON, Canada). The polymerase chain reaction (PCR) for amplification of DNA was performed $\left(\mathrm{S} 1000^{\mathrm{TM}}\right.$ Thermal Cycler, Bio-Rad Life Science Group, Canada) with the blocks preheated to the denaturation temperature of $96^{\circ} \mathrm{C}$. The thermocycling conditions included the following steps: 1) initial denaturation at $96^{\circ} \mathrm{C}$ for 1 minute; 2) primer annealing, beginning at $65^{\circ} \mathrm{C}$ in the first cycle and decreasing by $1^{\circ} \mathrm{C}$ in each of 10 subsequent cycles, with annealing at $55^{\circ} \mathrm{C}$ in final 30 cycles; 3) elongation step at $72^{\circ} \mathrm{C}$ for 3 minutes. The size of the PCR product for each sample was determined by gel electrophoresis (1\% agarose gel with $1.2 \mu \mathrm{L}$ SYBR ${ }^{\circledR}$ safe DNA stain (Invitrogen, Burlington, ON, Canada)). A standard curve was plotted based on three dilutions of a 100-bp molecular weight ladder (MBI Fermentas, Amherst, NY, USA).

\section{II) DNA Sequencing and Phylogenetic Analysis.}

DNA sequencing of the PCR products was performed at the Centre for Applied Genomics at SickKids in Toronto with an Applied Biosystems SOLiD 3.0 system. A single consensus sequence was generated from the forward and the reverse nucleotide sequences using BioEdit Sequence Alignment Editor (Version 7.0.9.0; Hall, 1999). NCBI database of 16S rRNA sequences (http://blast.ncbi.nlm.nih.gov/Blast.cgi) was used to BLAST search the resulting consensus sequence followed by sequence alignment using Clustal W (http://www.ebi.ac.uk/clustalw/). Construction of the phylogenetic tree was done by a neighbor-joining algorithm with MEGA v5.05. 


\subsubsection{Removal of bacterial cells from bentonite}

Various chemical and physical techniques are used for removal of bacteria from sediments. MermillodBlondin et al. (2001) suggested that ultrasonic baths are commonly used for removal of bacteria from sediments before subsequent direct enumeration, and are considered to be one of the most efficient methods used. In order to physically remove the cells without introducing chemical components, two methods were employed, namely exposure of the bacteria cells to ultrasound and vortexing, to determine the most effective method for removal and separation of bacterial cells from solid clay particles. The optimal method was determined using various ultrasound exposure times at $40 \mathrm{kHz}$, vortexing at $3000 \mathrm{RPM} / \mathrm{min}$ for various exposure times, and a sequential combination of both (vortexing first followed by sonication, and sonication as first step followed by vortexing) at various time intervals for removal of Arthrobacter spp. cells (a Gram-positive bacterial strain, isolated from indoor air by Ronan et al., (2013)). Furthermore, the effectiveness of cell removal was examined at various $\mathrm{pH}$ levels and temperatures, using $\mathrm{HCl}(1 \mathrm{~N})$ and $\mathrm{NaOH}(2 \mathrm{~N})$ solutions to adjust the $5 \mathrm{~mL}$ saline solution to either $\mathrm{pH} 7$ or 9 before the cell removal step, and incubation at 15,25 , and $37^{\circ} \mathrm{C}$ of the bentonite-buffer mixtures. The mixtures were incubated in a water bath for 2 hours and the temperature of the solution was measured after the incubation period. Cell removal for this $\mathrm{pH} /$ temperature experiment involved a sonication period of 20 minutes and/or vortexing for 5 minutes as described above.

\subsubsection{Investigating the survival of bentonite isolates after desiccation at glass-air interfaces}

For experiments involving bacteria survival at glass-air interfaces each bentonite isolate and the bacteria strain Arthrobacter spp. were grown in TSB $\left(3 \mathrm{~g} \mathrm{~L}^{-1}\right)$ for 16-20 hours at room temperature with 
agitation. The cultures were then washed three times by centrifugation at 8,000 RCF followed by removal of the supernatant and suspension of the pellet in sterile distilled water. Survival of the selected strains was based on utilization of a culture dependent method for viability determination after prolonged periods of desiccation. The first step involved inoculation of $0.1 \mathrm{~mL}$ of the washed culture on the surface of sterile microscope coverslips $(0.16 \mathrm{~mm} \times 18 \mathrm{~mm} \times 18 \mathrm{~mm}$ (VWR International, USA)) using the large droplet inoculation method. The large droplet method involves inoculation of $0.05-0.1 \mathrm{~mL}$ of washed culture on the surface that is under investigation (Robine et al., 1998). This method has been previously used for testing long-term survival of bacteria and allows rapid and replicable inoculation from a specific volume of the culture onto various substrates (Makison and Swan, 2006; Yazgi et al., 2009; Ronan, 2012;). After inoculation, the coverslips were allowed to dry by a laminar flow ventilation hood (ambient relative humidity $(\mathrm{RH})$ of $60 \pm 5 \%$ ) for 6 hours. Sacrificed duplicate coverslips were used immediately after drying and at each time point $(1,3,5,6,8$, 14, 30 days after drying) for enumeration of viable bacteria. The coverslips were kept in sterile Petri dishes inside a humidity chamber (GasPak Chamber, Becton Dickson, Franklin Lakes, NJ, USA) and monitored by an Indoor/Outdoor Hygro-Thermometer (Extech Instruments, Waltham, MA, USA). Throughout the experiment, the relative humidity (42 $\pm 3 \%$ ) was kept constant using a saturated salt solution (magnesium chloride) prepared as described by Greenspan (1977). Sampling was done by using duplicate coverslips at each given time point and placing each coverslip in a $50 \mathrm{~mL}$ sterile polyethylene tube with $5 \mathrm{~mL}$ of sterile $0.9 \% \mathrm{NaCl}$ and vortexing for one minute at high speed (3000 $\mathrm{RPM} / \mathrm{min}$ ). The solution was used for preparation of a serial dilution and plating of duplicate samples onto $3 \mathrm{~g} \mathrm{~L}^{-1}$ TSA plates followed by incubation at room temperature for 2-5 days. Viable cells were expected to decrease exponentially over time, and loss of viable cells was modeled according to: $C_{\mathrm{t}}=\mathrm{C}_{0} \mathrm{e}^{-\mathrm{kt}}$ 
Where $C_{t}$ is cell density at time $(t)$ [days], $C_{o}$ is initial cell density, and $k$ is a first-order loss rate [day ${ }^{-1}$ ]. Viable cell counts (ln transformed) were plotted against time and fit to a linear regression, the slope of which represents $\mathrm{k}$.

\subsubsection{Investigating the survival of Arthrobacter spp. after desiccation at bentonite-air interfaces}

The bacteria strain Arthrobacter spp. was grown for 16-18 hours in TSB (3 $\left.\mathrm{g} \mathrm{L}^{-1}\right)$ at room temperature with agitation. Cultures were centrifuged at 8,000 RCF for five minutes and the pellet was resuspended in sterile distilled water. This washing step was repeated three times to ensure that the nutrients from the enrichment media were removed. Survival of Arthrobacter spp. cells were assessed based on bacterial viability after prolonged periods of desiccation using a large droplet inoculation method. Two experimental methods were developed for investigating the survival of bentonite isolates after desiccation: I) Preparation of a bentonite sheet covering glass coverslips, using bentonite slurry followed by large inoculation method; II) Inoculation of dry bentonite (image can be found in Appendix A) by mixing.

The bentonite slurry $(0.2 \mathrm{~g} / \mathrm{mL})$ was prepared by saturation of sterile bentonite clays (2.5 MRad irradiation dosage, Department of Chemical Engineering, University of Toronto) with autoclaved saline $(0.9 \% \mathrm{NaCl})$ followed by vortexing for 30 minutes. Then $0.5 \mathrm{~mL}$ of the slurry was spread out on to the surface of a glass coverslip. All coverslips were placed in a laminar flow ventilation hood to allow complete drying and coverslips with cracked bentonite sheet sections were discarded. A large droplet containing $0.1 \mathrm{~mL}$ of the washed bacteria suspensions was inoculated onto each coverslip. The coverslips were allowed to dry under a laminar flow ventilation hood and during this time the ambient humidity was not regulated $(60 \pm 5 \%)$ for 4 hours. The survival investigation started 24 hours after drying, with incubation at room temperature. The proportion of cells lost was determined for triplicate 
coverslips by placing each coverslip in a $50 \mathrm{~mL}$ sterile polyethylene tube with $5 \mathrm{~mL}$ of sterile $0.9 \%$ $\mathrm{NaCl}$, followed by removal of the cells from the coverslip using the conditions summarized in Table 3 involving sonication and/or vortexing at various time intervals or addition of $\mathrm{pH}$ and temperature adjustment and spot plating from a serial dilution onto $3 \mathrm{~g} \mathrm{~L}^{-1} \mathrm{TSA}$ plates.

The dry bentonite investigation was performed by mixing of $1 \mathrm{~g}$ of dried sterile bentonite clays (2.5 MRad irradiation dosage, Department of Chemical Engineering, University of Toronto) with 0.1 $\mathrm{mL}$ of the washed bacteria suspension to prevent aggregate formation by using a sterile rod with the clays inside a falcon tube followed by incubation at room temperature for 24 hours. The clays were then saturated with $5 \mathrm{~mL}$ of autoclaved $0.9 \%$ saline and the cell removal steps are outlined in Table 3, followed by enumeration (as above).

Table 3. Treatment conditions for validation of cell removal from unsaturated bentonite clays

\begin{tabular}{|l|l|l|}
\hline Bentonite form & Separation method & Duration (min) \\
\hline Dry film from slurry (on & 1)Vortex & $0,1,5,10$ \\
2)Sonication & $0,1,5,10,20,40,60$ \\
& 3) Vortex -sonication & 5,20 \\
& 4)Sonication-vortex & 20,5 \\
\hline Dry bentonite (1 g) & 1) Vortex & $0,5,10,20$ \\
& 2) Sonication & 40,10 \\
& 3) Vortex-sonication & 10,40 \\
\hline
\end{tabular}




\section{$4.3 R$ es u 1 t s}

\subsubsection{Isolation and characterization of cultivable aerobic bacteria isolated from bentonite}

A total of 10 aerobic bacteria were isolated from commercially purchased MX-80 bentonite clays. The phylogenetic analysis based on 16S rRNA gene sequences indicates that all bentonite isolates were closely related to species isolated from similar environments (Figure 10). A number of identified isolated bacteria in this study were previously isolated in other studies involving bentonite barriers for containment of highly radioactive waste. Table 4 provides a brief description of the physiological characteristics of each bacteria isolated.

\subsubsection{Removal of bacterial cells from bentonite}

Vortexing and sonication of samples appeared to be successful strategies for removal of desiccated Arthrobacter spp. cells from bentonite sheets on glass slides (Figure $11 \mathrm{a}, \mathrm{b}$ ) or from dry bentonite particles (Figure $11 \mathrm{c}, \mathrm{d}$ ). Vortexing for 5 minutes appeared to be sufficient for removal of cells from bentonite sheets, while 10 minutes was sufficient for removal from particulate bentonite. Sonication of 5 minutes appeared sufficient for removal of cells, and longer periods did not yield significantly more cells from either bentonite sheets or particles.

A follow-up experiment explicitly compared vortexing, sonication, vortexing followed by sonication, and sonication followed by vortexing to determine which strategy would be most successful for removing viable cells from bentonite. There was no statistical difference between vortexing for 5 min, sonicating for $20 \mathrm{~min}$, or sonicating for $20 \mathrm{~min}$ followed by vortexing for $5 \mathrm{~min}$ (Figure 12 a). Unexpectedly, there was a slight decrease in viable cell recovery when bentonite sheets were first 
vortexed for $5 \mathrm{~min}$ followed by sonication for $20 \mathrm{~min}$ (ANOVA, removal strategy effect $F_{3,12}=9.136$, $P=0.002)$. This may be a spurious result, as there was no statistical difference among these same strategies for removal of viable cells from dry, particulate bentonite $\left(F_{3,12}=1.686, P=0.223\right)$.

Different combinations of $\mathrm{pH}(7$ and 9$)$ and temperature $\left(15,25\right.$, and $\left.37^{\circ} \mathrm{C}\right)$ were tested to determine their impact on removal of viable cells from bentonite. Temperature did affect removal of cells from bentonite sheets (on glass coverslips), with recovery of viable cells increasing with temperature (Figure 12b; temperature effect $\left.F_{2,12}=20.036, P=<0.001\right)$. There was not, however, a similar temperature effect in dry, particulate bentonite $\left(F_{2,12}=0.492, P=0.623\right)$. There was no effect of $\mathrm{pH}$ on recovery of viable cells from either bentonite sheets $\left(F_{1,12}=3.069, P=0.105\right)$ or dry, particulate bentonite $\left(F_{1,12}=\right.$ 0.758, $P=0.401)$. 


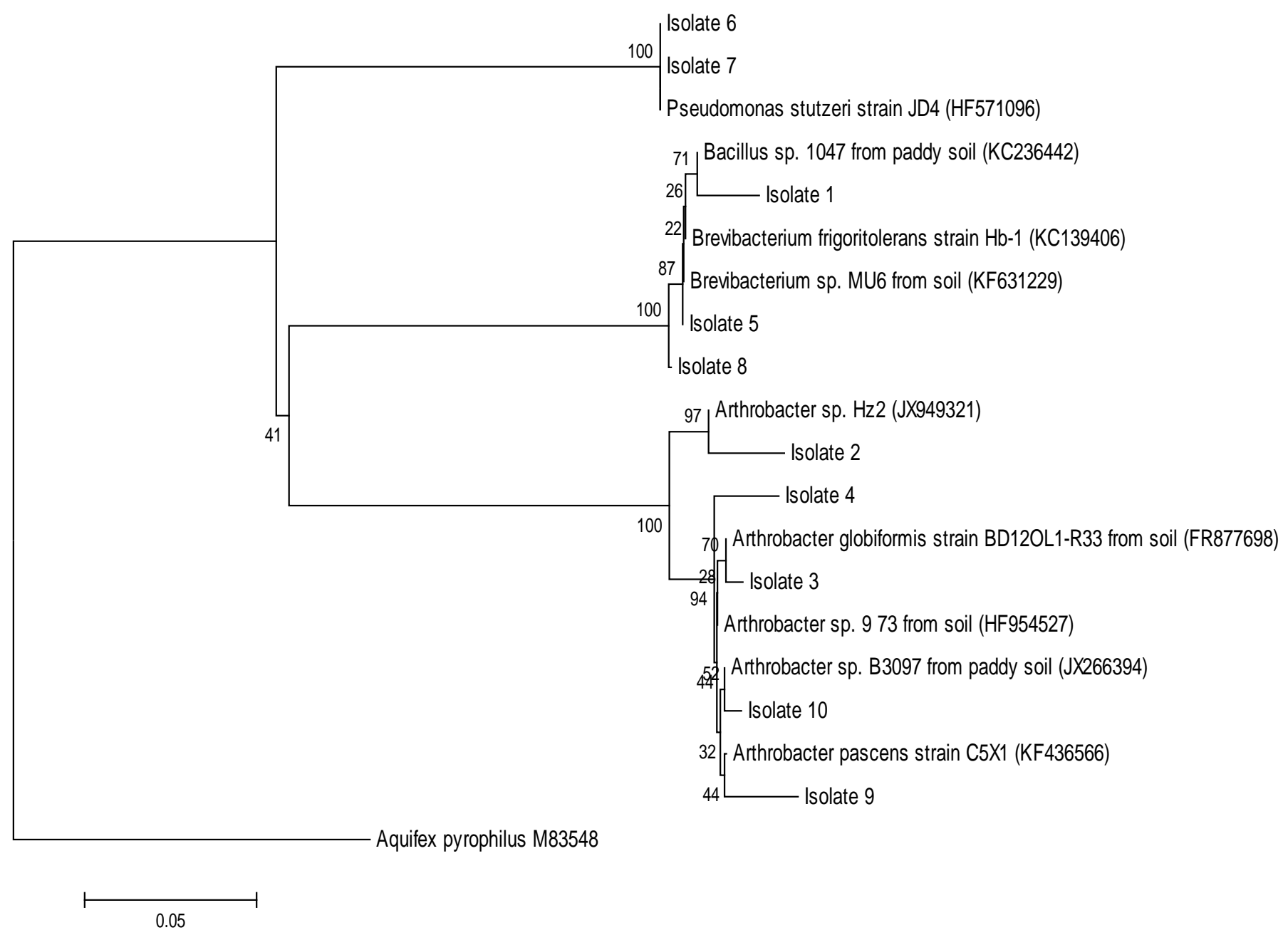

Figure 10.The phylogenetic position of the 10 aerobic bentonite isolates along with the most closely related identified species.

The similarity of bentonite isolates is based on the V3-V4 regions as described in the variability map of Van de Peer et al., 1996) of the16S rRNA. The construction of the tree was done by neighbourjoining algorithm with the numbers on the nodes corresponding to the values obtained from bootstrap on 1000 replicates. The out-group was done using Aquifex pyrophilus with scale bar indicating the approximate number of base changes per position of nucleotide sequence. 
Table 4. Summary of relevant findings on the effect of desiccation on the identified isolated indigenous bacteria from bentonite clays

\begin{tabular}{|c|c|c|c|}
\hline $\begin{array}{l}\text { Isolate } \\
\text { Number }\end{array}$ & Identification & Physiological Characteristics for Stress Tolerance & $\begin{array}{l}\text { Previously described from } \\
\text { bentonite }\end{array}$ \\
\hline Isolate 1 & Bacillus sp. 1047 & $\begin{array}{l}\text {-Endospore formation } \\
\text {-Spores resistant to radiation, heat, desiccation and } \\
\text { toxic chemicals (de Benito Armas et al., 2008) }\end{array}$ & $\begin{array}{l}\text { Pedersen et al., } 2000 \\
\text { Chi et al., } 2008\end{array}$ \\
\hline $\begin{array}{l}\text { Isolate } \\
2,3,4,9 \\
10\end{array}$ & Arthrobacter spp. & $\begin{array}{l}\text {-Non-spore-forming bacteria } \\
\text {-Desiccation tolerance } \\
\text {-Production of compatible solutes } \\
\text {-Lower zone community of rocks in Dry Valley of the Ross Desert, } \\
\text { Antarctica with prolonged periods of evaporation and extreme } \\
\text { environment (Kappen and Friedmann, 1983) }\end{array}$ & Chi et al., 2008 \\
\hline Isolate 5,8 & $\begin{array}{l}\text { Brevibacterium } \\
\text { spp. }\end{array}$ & $\begin{array}{l}\text { - Non-spore-forming bacteria } \\
\text {-Chemoorganotrophic } \\
\text {-Cold resistance } \\
\text {-Growth in } 2 \% \text { or } 5 \% \mathrm{NaCl} \text { medium } \\
\text {-Selenium tolerance (some strains up to } 15.9 \mathrm{mg} \mathrm{SeL}^{-1} \text { ) } \\
\text { (Tong et al., 2014) } \\
\text {-Lower zone community of rocks in Dry Valley of the Ross Desert, } \\
\text { Antarctica with prolonged periods of evaporation and extreme } \\
\text { environment (Kappen and Friedmann, 1983) }\end{array}$ & $\mathrm{N} / \mathrm{Ap}$ \\
\hline Isolate 6,7 & $\begin{array}{l}\text { Pseudomonas } \\
\text { stutzeri }\end{array}$ & $\begin{array}{l}\text { - Non-spore-forming bacteria } \\
\text {-Facultative anaerobe } \\
\text { - Remarkable physiological and biochemical diversity and flexibility, } \\
\text { organotrophy with wide range of organic substances, oxidation of } \\
\text { inorganic substrates by chemolithotrophy, resistance to heavy metals, } \\
\text { recycling of C,N,S, and P, wide range temperature support (Lalucat et } \\
\text { al., 2006) } \\
\text {-Some members of barotolerant (Kaneko et al., 2000) } \\
\text {-Wide range of temperature support (Kaneko et al., 2000) }\end{array}$ & $\begin{array}{l}\text { Stroes-Gascoyne \& West, } \\
1997 \\
\text { Stroes Gascoyne et al., } 1997 \\
\text { Pedersen et al., } 2000 \\
\text { Chi et al., } 2008\end{array}$ \\
\hline
\end{tabular}



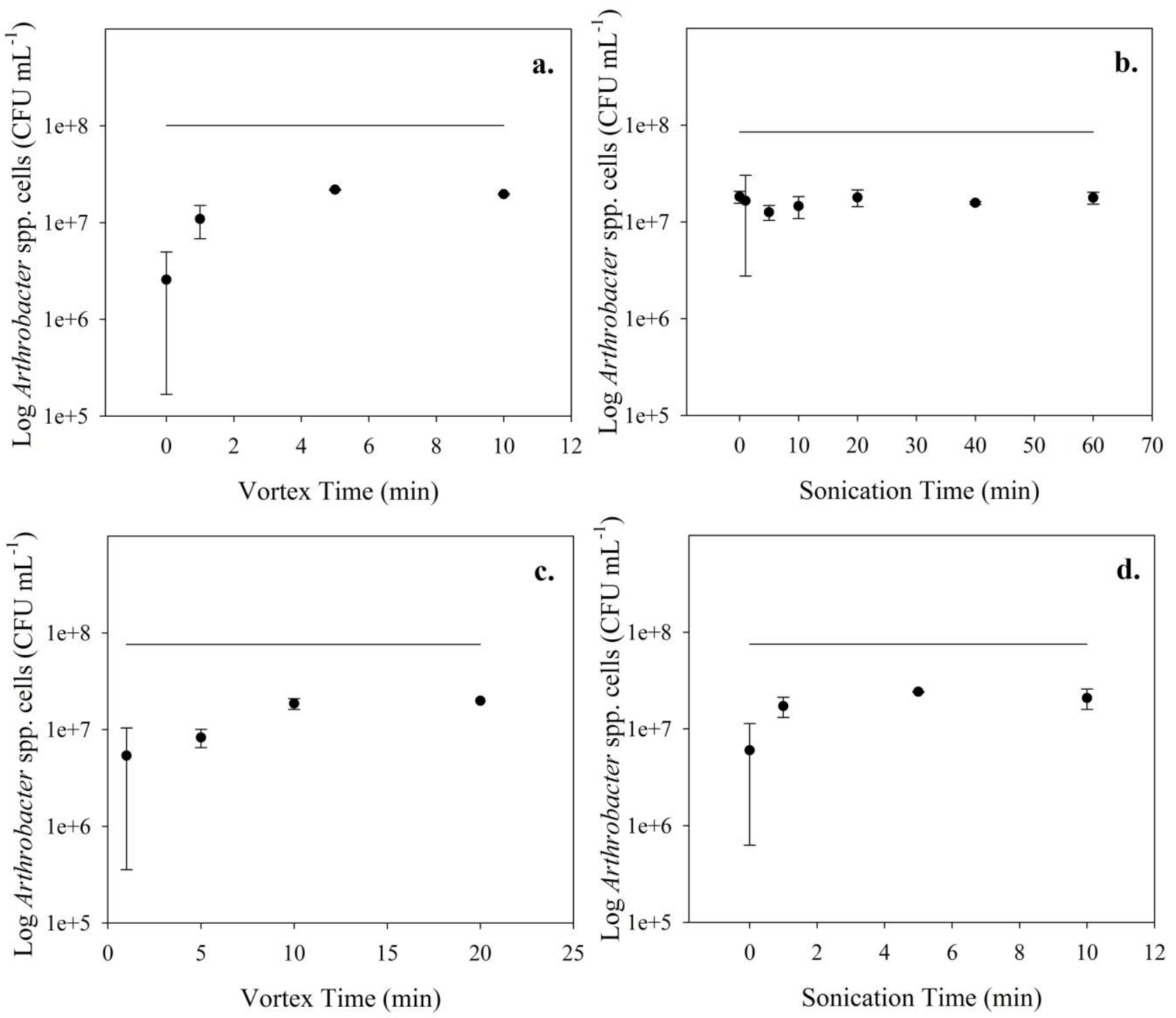

Figure 11. Removal of viable (culturable) Arthrobacter spp. cells from the dried bentonite sheet (on glass coverslips) by (a) vortex or (b) sonication for various time intervals, 24 hours after inoculating coverslips under conditions of desiccation and nutrient starvation and incubation at room temperature.

Removal of viable culturable Arthrobacter spp. cells from $1 \mathrm{~g}$ of dry bentonite by (c) vortex or (d) sonication for various time intervals, 24 hours after inoculation under conditions of desiccation and nutrient starvation, incubation at room temperature. Line represents the viable (culturable) cell counts in inoculum at time zero. Symbols represent mean viable cell counts in media following removal by sonication or vortex. Error bars represent standard deviation. The line represents the Log Arthrobacter spp. cells (CFU $\mathrm{mL}^{-1}$ ) in the inoculum prior to inoculation followed by desiccation. 

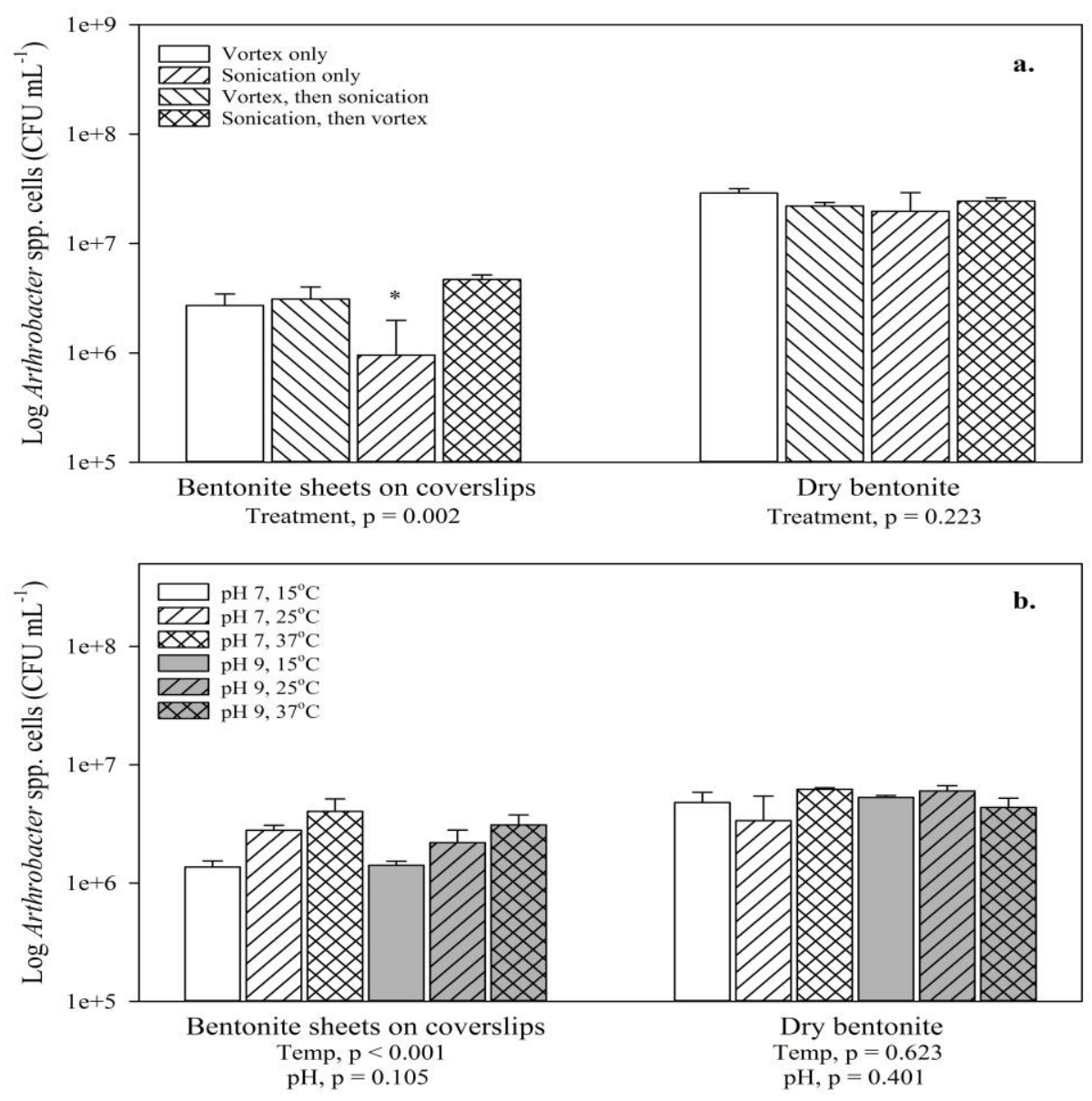

Figure 12. a) Removal of viable (culturable) Arthrobacter spp. cells from dried bentonite sheets on glass coverslips, and on solid, dry bentonite.

Cells were removed by the individual and combinational treatments. For bentonite sheets, treatments included: 1) vortexing for $5 \mathrm{~min}, 2$ ) sonication for $20 \mathrm{~min}$, 3) vortexing for $5 \mathrm{~min}$, followed by sonication for $20 \mathrm{~min}$, 4) sonication for $20 \mathrm{~min}$, followed by vortexing for $5 \mathrm{~min}$. For solid, dry bentonite, cell removal treatments included: 1) vortexing for $10 \mathrm{~min}, 2$ ) sonication for $40 \mathrm{~min}, 3$ ) vortexing for $10 \mathrm{~min}$, followed by sonication for $40 \mathrm{~min}$, 4) sonication for $40 \mathrm{~min}$, followed by vortexing for $10 \mathrm{~min}$. Statistically-significant differences (relative to other treatments) indicated by *. b) Removal of viable Arthrobacter spp. cells from dried bentonite sheets on glass coverslips, and on solid dry bentonite under different $\mathrm{pH}$ and temperature conditions. Cells were removed from bentonite by sonication for $20 \mathrm{~min}$. 


\subsubsection{Survival of bentonite isolates after desiccation at solid-air interfaces}

Six of the bacterial strains isolated from bentonite, and an additional Arthrobacter spp. previously isolated in the laboratory, were inoculated onto bentonite sheets (on glass coverslips) and dried. The Bacillus spp. and Psendomonas stutzeri isolates had poor survival of viable (culturable) cells, with loss rates of $>1 \mathrm{~d}^{-1}$ (or 100\% loss within $1 \mathrm{~d}$ of desiccation) (Table 5). In contrast Arthrobacter spp. isolates had much greater survival, with cell loss rates of 0.05 to $0.15 \mathrm{~d}^{-1}$. Generally, culturable Arthrobacter spp. could be separated from bentonite sheets 28 days after desiccation and nutrient starvation.

Table 5.Loss of viable cells (culturable) for bacterial strains isolated from bentonite (isolates 1, 2, 3, 4, 6, 9) or indoor air (Ronan et al., 2013). Cells inoculated to glass coverslips, and maintained under conditions of desiccation and nutrient starvation. Loss represented as first-order rate of decrease. The relative humidity was maintained at $42 \pm 3 \%$ throughout the experiment with exception of the first 4 hours (at ambient RH $(60 \pm 5 \%)$ ).

\begin{tabular}{|l|l|}
\hline Isolate & Rate of viable cell loss $\left.\mathbf{~} \mathbf{d}^{-1}\right)$ \\
\hline Bacillus sp. (isolate 1) & 2.29 \\
Arthrobacter spp. (isolate 2) & 0.11 \\
Arthrobacter spp. (isolate 3) & 0.07 \\
Arthrobacter spp. (isolate 4) & 0.14 \\
Arthrobacter spp. (isolate 9) & 0.15 \\
Arthrobacter spp. (Ronan et al., 2013) & 0.05 \\
Pseudomonas stutzeri (isolate 6) & 1.88 \\
\hline
\end{tabular}




\section{4 Discussion}

The bacteria isolated in this study were similar to several previously reported isolates from bentonite clays (Table 4) under the conditions relevant to the Canadian vault design. Additional information about the isolated bacteria in this study can be found in Appendix D. Previous in situ experiments on the performance of compacted bentonite relevant to Canadian vault design have demonstrated a significantly low number of viable microbes (including heterotrophic and specialized bacteria) (StroesGascoyne et al., 1997). Despite numerous investigations, the prime concern of most studies in the context of a vault is directed at survival of spore-forming bacteria, especially sulfur reducing bacteria (SRB) due to prime concerns regarding microbially-influenced corrosion (MIC) activities. Currently, dormancy is considered as the most common strategy for microbial long-term, high stress tolerance and resistance during adverse environmental conditions during which bacterial cells remain inactive (Johnson et al., 2007). Numerous investigations demonstrated that some bacterial spores have shown resistance to heat (Gomez-Jodar et al., 2015; Marshall et al., 2015; Setlow, 2006; Murrell and Scott, 1965), adverse physical conditions (Pedersen et al., 2000), desiccation (Tirumalai and Fox, 2013; De benito Armas et al., 2008; Setlow, 2006;), radiation (Friedline et al., 2015; Tirumalai and Fox, 2013), and chemical agents (Friedline et al., 2015; Leggett et al., 2012; Pedersen et al., 2000). Johnson et al., (2007) reported that maintenance of low-level cellular metabolic activities and DNA repair is essential for sustaining viability overtime, making the survival of vegetative cells superior to dormancy. The physiological distinct forms of the vegetative cells of many species of bacteria that differentiate can be classified as endospores, exospores, myxospores, cysts, akinetes, and resting stages (Potts, 1994). Considering that bacteria indigenous to bentonite clays and strains that are introduced during the 
bentonite block preparation will be present in the vicinity of used spent fuel canisters, detailed investigations on survival of non-spore forming bacteria at bentonite-air interfaces are required.

While endospore formation is a major advantage that allows for survival of bacteria species under a large range of hostile environmental conditions, vegetative bacteria cells can survive in a desiccated state at solid-air interfaces. Vegetative anhydrobiotic bacterial cells can be defined by their singular deficiency in water, which is far greater than a cell under osmotic stress or freeze tolerance cells covered in extracellular ice, where their major constituents lack a monolayer of water (Potts, 1994). Drying of bacteria cells at relative humidity (RH) of $40 \%$ and $30 \%$ leads to cell water content of $0.1 \mathrm{~g}$ $\mathrm{H}_{2} \mathrm{O}$ per g dry weight and $0.03 \mathrm{~g}$ of $\mathrm{H}_{2} \mathrm{O}$ per g dry weight, respectively, and this lower limit represents the value measured in anhydrobiotic cell types. The water content of bacterial spores is lower than their parent vegetative cells, ranging from $0.21-0.58 \mathrm{~g}$ of $\mathrm{H}_{2} \mathrm{O}$ per $\mathrm{g}$ dry weight, and this value is indeed higher than anhydrobiotic cells (Potts, 1994). Eight out of ten isolated indigenous bacteria were nonspore-forming bacteria and the Arthrobacter spp. species displayed tolerance to various environmental stress conditions including nutrient starvation and desiccation (Table 5). During rehydration, the rate of reactions that leads to changes in the physiological state of bacteria cells seems to be species dependent. Potts (1994) reported that instantaneous appearance of moisture gradient, rapid dilution of reactants and activation of enzymes are among reactions that occur during rehydration of the cell at rates that vary among species. Our results show that the viable cell loss $\left[\mathrm{d}^{-1}\right]$ rate of Arthrobacter spp. (Table 5) varied for different strains of the same genus and species (not shown as no culturable viable counts were detected immediately after desiccation). Bacteria strains of Arthrobacter spp. demonstrated variation in their ability to survive during prolonged periods of desiccation with lack of nutrient availability at hydrophobic glass-air interfaces used for immobilization and drying of the isolated 
indigenous bentonite bacteria. Additional means for better visualization of dried cells using similar method outlined here at inanimate solid-air interfaces were explored and outlined in Appendix E.

The use of saturated salt solutions for investigating survival of microorganisms under desiccation is common for the vapour equilibrium technique and was used for conducting the cell removal experiments in this study (Delage et al., 1998; Saiyouriet et al., 2001; Loiseau, 2001; Montes-H et al., 2003; Tang and Cui, 2007). This technique involves suction ranging from $3 \mathrm{MPa}$ to $1000 \mathrm{MPa}$ depending on the salt solution and has been recommended for bentonite because of high activity of swelling clays (Tang and Cui, 2007; Tessier, 1984, Romero, 1999, Villar, 2000). This method is advantageous for maintaining a constant value for molar fraction of water in a solution with RH changes between the liquid and gas phase (Tang and Cui, 2007). A disadvantage of employing this method for a porous medium is that the use of salt solutions in a closed chamber for decreasing water vapor in equilibrium with desiccated microbial cells may not mimic natural environments, where cells are hydraulically disconnected and mass exchange is prevented. Matric potential changes the properties of water organization and associated diffusional patterns and therefore it is essential to ensure homogeneity of the porous medium to expose cells to matric potential (Or et al., 2007). Immobilization of bacteria cells in the form of slurry on various inert supports including sterile sand was recommended by Potts (1994), which provides rapid drying of microorganisms. In our study, Arthrobacter spp. cells were immobilized in the form of slurry on inert glass surface. Although cells can be successfully removed from bentonite using both methods, higher numbers of viable Arthrobacter spp. cells were removed from the dry bentonite tubes compared to the bentonite sheets on coverslips 24 hours after drying. 
The present study shows that physical cell removal methods can be used to remove desiccated, but viable, cells from bentonite-air interfaces for examination of bacteria survival. Numerous studies reported clay mineral montmorillonite materials interaction with bacteria cells by binding to biopolymers such as proteins and nucleic acid (Lorenz and Wackernagel, 1992; Lavie and Stotzky, 1986; Khanna and Stotzky, 1992; Theng and Orchard, 1995; Cui et al., 2006). Bacteria-clay interactions are complex as both the surface of bacterial cells and the surface of crystalline clays are negatively charge and can be defined by adhesion and sorption of bacteria to the surface of the clays.

Adhesion is indirect by production of extracellular polymerase substances (EPS) or macromolecule structures. Bacterial cells are capable of producing surface layers including capsules, fibrils, and polymers that are mainly composed of polysaccharides providing them with glue like properties for attachment and distanced extension from their surface to the surface of the clay (Theng and Orchard, 1995; Potts, 1994). Additionally, Gram-negative bacteria with positively charged pili are capable of attaching to negatively charged surfaces under neutral $\mathrm{pH}$ (Theng and Orchard, 1995). In contrast to adhesion, sorption involves accumulation of bacteria at the bentonite clay surface and is mainly dependent on the electrolyte concentration, or the $\mathrm{pH}$ of the clay matrix. This process occurs by formation of polycationic bridges between the mineral surface and cell promoted by increase in the valence of the $\mathrm{Al}^{3+}$ and $\mathrm{Fe}^{3+}$ elements by formation of polyhydroxy species $\left[(\mathrm{Al}, \mathrm{Fe})_{\mathrm{x}}\left(\mathrm{OH}_{\mathrm{y}}\right)\right]^{(3 \mathrm{x}-\mathrm{y})}$. $\mathrm{nH}_{2} \mathrm{O}$. Thus positive charge is added to the surface of the cell and if accumulated by the cell, formation of clay-enveloped cells by smaller clay particles can possibly occur. Contrary to some previous literature, $\mathrm{pH}$ had no effect on efficiency of cell removal from bentonite. Exposure of cells to desiccation under matric stress and nutrient starvation plays an active role in altering bacterial interactions with their immediate environment (with clay particles at bentonite-air interfaces). During 
the cell removal stage, removal of cells was not affected by changes in the $\mathrm{pH}$ of the medium for both the dry bentonite and bentonite sheet methods as illustrated in Figure 12b. Considering that sorption is affected by the $\mathrm{pH}$ of the clay matrix, desorption of the desiccated cells was not enhanced based on data obtained from this study for both methods outlined in this study.

A study conducted by Fletcher (1976) suggested that attachment of a marine pseudomonad to surfaces was influenced by temperature with noticeable decrease at lower temperature $\left(3^{\circ} \mathrm{C} \pm 1\right)$ compared to higher temperature of $20^{\circ} \mathrm{C}$. He concluded that changes in temperature can lead to changes in the viscosity of polymers associated with the surface of bacteria and the viscosity of the medium. Higher temperature, depending on the specific limits of the solution under investigation, can favour chemisorption and physical adsorption of solutes in a solution. Further, temperature could influence adhesion based on the physiological response (on the bacterium part that initially comes in contact with the surface) of organisms (Fletcher, 1976). McCaulou et al. (1995) observed that bacteria motility through sediments was affected due to changes in attachment-detachment kinetics. Decrease in temperature $\left(4^{\circ} \mathrm{C}\right)$ led to absence of flagella metabolism and higher attachment of bacteria to the sediment grains for longer periods (9-17 days before detachment), whereas at higher temperature detachment period was 4-5 days (McCaulou et al., 1995). Our results show that removal of cells from dry bentonite was not influenced by changes in temperature ranging from $15-37^{\circ} \mathrm{C}$ indicating weak reversible interaction between the cell and surface. However, our data supported that temperature influenced the removal of cells from a bentonite sheet on a glass substrate. It is possible that changing the temperature of the medium affected the removal of the bentonite sheet from the glass surface, allowing for more effective cell removal by subsequent physical cell removal steps of sonication and vortexing. 


\subsection{Conclusion}

Overall, MX-80 bentonite clays serve as a unique model to study desiccation tolerance of bacteria at solid-air interfaces. The rate of viable cell loss for desiccation tolerant Arthrobacter spp. species was lower than other isolated species from bentonite. Both methods presented here demonstrated successful removal of cells from bentonite either by sonication for more than 10 minutes or by vortexing for more than 5 minutes. During cell removal, efficiency of cells removal does not change when comparing the samples of $\mathrm{pH} 7$ with $\mathrm{pH} 9$ for the methods outlined in our study. The influence of temperature within limits $\left(15-37^{\circ} \mathrm{C}\right)$ for removing desiccated cells from bentonite can vary and needs to be verified for the method employed. Verification steps are recommended based on physiological characteristics of the bacteria under investigation. 


\section{SIGNIFICANCE, CONCLUDING REMARKS, AND FUTURE RESEARCH RECOMMENDATIONS}

Here we have established approaches to investigate bacterial survival at solid-air interfaces under desiccation with absence of nutrients for gaining insights to devise control measures such as inhibition or preservation of bacteria populations. The following final conclusions were drawn from this study:

1. Review of collective studies that assess microbiology of DGR concepts confirm that MX-80 bentonite compacted to $2 \mathrm{Mg} / \mathrm{m}^{-3}$ that is water saturated to $26 \% \mathrm{v} / \mathrm{w}$ ( $\mathrm{a}_{\mathrm{w}}$ of 0.96 ) offers sufficient inhibition of microbial activity. The in situ experiments with a DGR's relevant conditions on the performance of compacted bentonite suggested that low viability of bacteria (the approximate background culturable bacteria cell numbers is $200 \mathrm{CFU} / \mathrm{g}$ of dry bentonite) is linked to bentonite's low water content (less than 15\%). Therefore, desiccation plays a key role for inhibiting proliferation, activity, and persistence of bacteria in the bentonite clay's distinct macro-and micro-environment.

2. Microorganisms in highly compacted bentonite surrounding used fuel containers will be exposed to high pressure, temperature and radiation, as well as limited water and nutrients. Microbiological survival and activity close to the emplaced canisters is limited and influenced by combined effects of high temperature, high levels of radiation, absence of water, and lack of available nutrients. Thus it is difficult to estimate microbial activities, given that the prime concern for a microbial community is survival and energy expenditure is regulated.

3. Interfaces formed by cracking as the clay barrier becomes desiccated may provide refuge where bacteria may survive. If the conditions change over time in the future (e.g. delivery of 
water), these are potential hotspot sites for enhanced microbial activity and sites of vulnerability due to production of metabolic byproducts. Despite a wealth of information on bacterial survival in aqueous-solid interfaces, very little is known about survival of bacteria under unsaturated solid-air interfaces.

4. Regions of low dry density within highly compacted bentonite possibly at interfaces (placement gaps, contact regions with materials of different densities) need to be assessed for potential formation of "hot spots" with elevated bacteria population density.

5. Long-term survival of bacteria cells at solid-air interfaces of DGR involving bentonite is greatly influenced by the degree and duration of water deficit in their environment, physical and geochemical conditions that are present within bentonite and at interfaces involving bentonite.

6. The relationship between the elemental composition of MX-80 bentonite clays and microbial food webs is indirect. While in survival mode, the bioavailability of the substrates limits utilization of elements by bacteria. Consideration of total nutrient availability based on bentonite's composition provides an estimate of worst-case available nutrients for bacterial survival and may not necessary reflect possible outcomes.

7. Further investigation into water film formation around the MX-80 clay envelope based on target saturation level of bentonite provides valuable information for gaining additional knowledge about bacterial survival.

8. There is limited knowledge available about the mechanisms that allow long-term survival of bacterial cells and mode of action for prevention of spontaneous genomic decay. Since prevention of spontaneous genomic decay is maintained by vegetative bacteria and is essential 
for long-term survival, further investigation into survival of vegetative bacteria during desiccation provides valuable insights for inhibiting bacteria populations.

9. Testing for survival of bacteria under environmental stress conditions in particular has been challenging both practically and theoretically. During survival depending on the extent of stress conditions and duration, the rate coefficient can be determined using $C_{t}=C_{0} e^{-k t}$.

10. Bentonite clays have been traditionally used as environmental isolation over the past two decades for physical isolation, as well as prevention of toxic and hazardous chemicals or biological processes. There is growing interest for the use of bentonite clays in the field of environmental technology as a physical, chemical, and biological barrier due to its low hydraulic conductivity and high specific adsorption. Method development for monitoring bacteria populations within bentonite saturated to varying degree is suitable as an environmental monitoring tool to assess microbial survival and activity under the target investigation conditions.

11. The comprehensive study presented in Chapter 3 assessed ecology and survival of bacteria at glass-air interfaces during desiccation with absence of nutrients.

- This study established that viable vegetative bacteria could survive at solid-air interfaces for extensive periods (more than 30 days) depending on speciesspecific mechanisms that the population is equipped with for the given stress condition. The decay rate of viable Arthrobacter spp. was lower than P. stutzeri cells under the same laboratory conditions. Furthermore, desiccated cells remain intact long after no viable counts are detected for both species.

- Closeness of cells by bioflocculation enhances survival of prokaryotes under desiccation at solid-air interfaces by localized the cells in close proximity to their 
siblings. Ultimately the survivor cells can shape the dominant morphology of a new heterogeneous population that can better manage the environmental condition that prevails. However, survival of survivor cells is conditional based on their immediate environment along with duration and extent of stress conditions to maintain prevention of genomic decay and low level cellular activities that are vital for cells.

- Alive status verification for bacteria is complicated. Consideration of viable counts as well as total bacteria counts allows for better detection for survival analysis, as survival places bacteria in a borderline state that is influenced by complex interaction of cells with their biotic and abiotic environment. This study shows that the total cell counts of intact bacteria are more stable than viable counts and survival of intact cells is independent from population density. Within compacted bentonite barrier, intact bacteria cells are physically burdened with combined effects of high pressure, high temperature, high radiation levels, mobility and space restrictions due to small pore size.

- Control and inhibition of microorganism at solid-air interfaces requires consideration of a microbial community rather than gathering observations from individual cellular response to target stress conditions under investigation. Close proximity of vegetative bacterial cells to their siblings during prolonged starvation and desiccation periods provides survival advantages to survivor cells. Bacterial community rely on intact cells to recycle and preserve nutrients, water, and essential elements at solid-air interfaces to survive during prolonged periods of desiccation with absence of nutrients. Presence of homogenized cells extends 
short-term survival of Artbrobacter spp. cells. Presence of heat-killed cells significantly extended viability of both Artbrobacter spp. and P. stutzeri cells longer.

- No viable counts were obtained for population sizes smaller than $10^{2} \mathrm{CFU} / \mathrm{mL}$ immediately after drying. Our data suggests that population size plays a significant role in survival of bacteria at solid-air interfaces. Considering that the background culturable viable heterotrophic counts from compacted bentonite are low, survival of bacteria at bentonite-air interfaces can be investigated for relevant population sizes.

12. Finding a suitable method for evaluating microbial survival during desiccation at bentoniteair interfaces using bacteria species that were relevant to an indigenous bentonite community was explored in Chapter 4.

- Previous studies reported that clay minerals including bentonite interact with bacteria cells by binding to biopolymers including proteins and nucleic acid. This study established that physical cell removal methods can be used to remove desiccated, but viable, cells from bentonite-air interfaces for examination of bacteria survival.

- Different bacteria species within the same genus that are closely related may demonstrate distinct characteristics. Thus, replication of the findings of this study using the methods developed can provide better insights about the relevance of this study to DGR's concept.

- Both methods presented here demonstrated successful removal of cells from bentonite either by sonication for more than 10 minutes or by vortexing for more than 5 minutes. 
- The efficiency of cell removal does not change when comparing the samples of pH 7 with $\mathrm{pH} 9$.

- The influence of temperature within limits $\left(15-37^{\circ} \mathrm{C}\right)$ for removing desiccated cells from bentonite can vary and needs to be verified for the method employed.

- Bentonite serves as a unique model to study desiccation tolerance of bacteria. There is greater emphasis on the use of culture dependent methods for microbial studies involving bentonite clays stemming from the challenges that are present for molecular based techniques due to formation of strongly bound bentonite clay-DNA complexes. The presented method allows for effective removal of bacteria cells from bentonite material for assessment of survival using culture dependent techniques and some concepts can be applicable to other microbial survival assessments at solid-air interfaces.

- Most studies that evaluate the effects of environmental stressors on bacterial ecology (both planktonic and biofilm forming cells) are directed at solid-aqueous interfaces and are based on pure culture studies. Since the guidelines provided by Canada's APM requires the environmental assessment to consider a period of a million years, assessment of mixed bacteria survival, ecology, and activities with long-term set up experiments is recommended.

Overall, our findings imply that gaining insights about bacterial survival at solid-air interfaces would be beneficial for better prediction and assessment of microbial populations that inhabit both the natural environment and diverse indoor environments. Survival of bacteria populations at solid-air interfaces is more complex when governed by intraspecific interactions among the members of the same species (among siblings as shown in this study) or further influenced by interspecific interactions with another 
microbial community in natural environments allowing for resiliency. Detecting vegetative bacteria populations that are not in their active mode of growth and proliferation presents a new challenge to traditional microbiology by changing our perception on viability and demands understanding this complexity for devising more relevant test methods to alleviate microbial dependent problems in industry, medicine, and natural environment. 


\section{APPENDIX A}

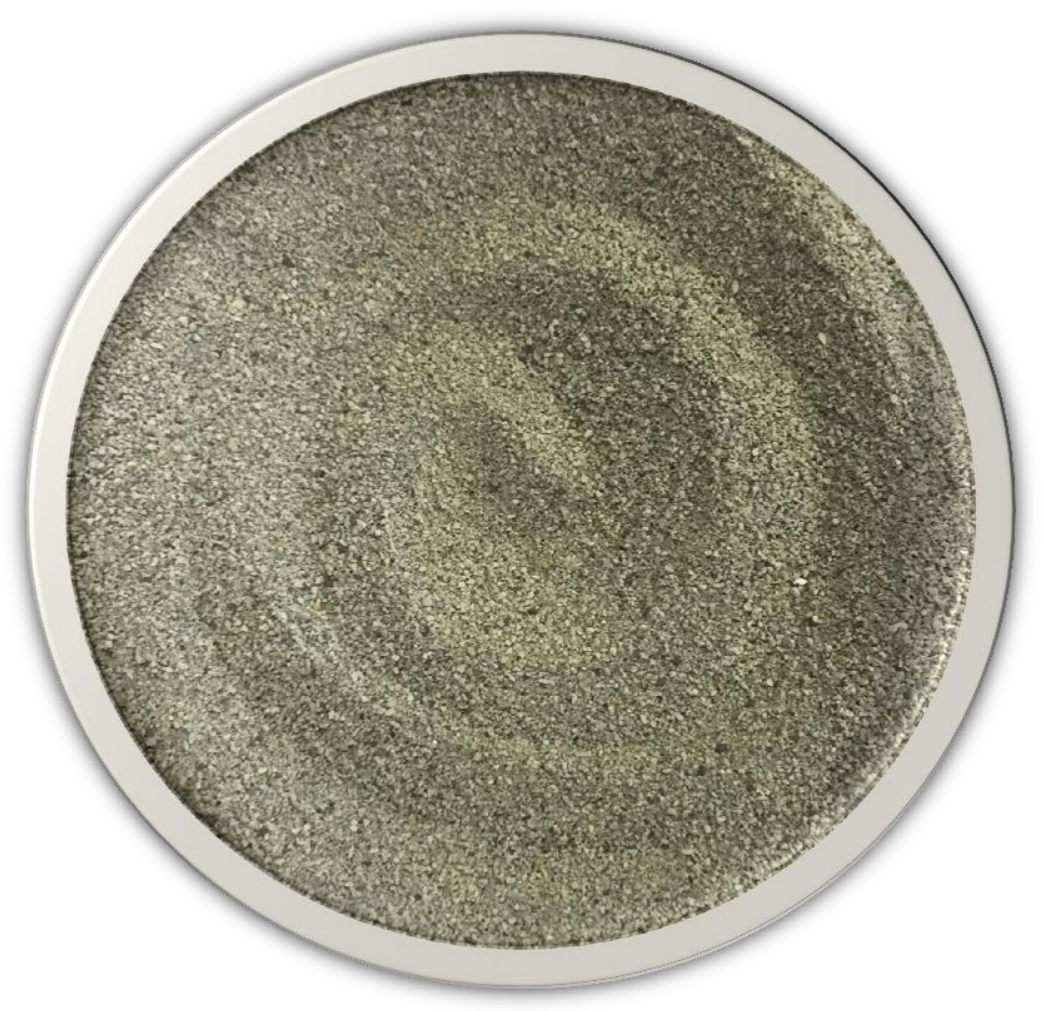

Figure 13. Dry Wyoming MX-80 Bentonite 


\section{APPENDIX B}

The acquired epifluorescence images presented in this section were obtained to monitoring existence of intact dried cells on the surface of glass coverslips by comparing three population densities of Gram-positive (Arthrobacter spp.) and Gram-negative (P. stutzeri) bacteria populations overtime throughout the duration of experiments. The associated population density of each monitored population is presented in Table 6 . The RH of all samples was maintained at $42 \pm 3 \%$ for duration of the experiment, with exception of drying period (initial 3 hours at $\mathrm{RH} 60 \pm 5 \%$ ). Values at time 0 represent the initial viable cells in each population and $\mathrm{T}$ is measured in days.

Table 6. Inoculated population density of monitored bacterial populations on the surface of

\begin{tabular}{|l|l|l|}
\hline Bacteria Name & $\begin{array}{l}\text { Population Density } \\
\text { (Viable Cells) }\end{array}$ & Population Name \\
\hline Arthrobacter spp. & $1.4 \times 10^{7}$ & Arthrobacter spp. Population 1 \\
\hline Arthrobacter spp. & $3.85 \times 10^{6}$ & Arthrobacter spp. Population 2 \\
\hline Arthrobacter spp. & $2.6 \times 10^{5}$ & Arthrobacter spp. Population 3 \\
\hline P. stutzeri & $7.5 \times 10^{5}$ & P. stutzeri Population 1 \\
\hline P. stutzeri & $1.7 \times 10^{5}$ & P. stutzeri Population 2 \\
\hline P. stutzeri & $4.5 \times 10^{4}$ & P. stutzeri Population 3 \\
\hline
\end{tabular}

coverslips 


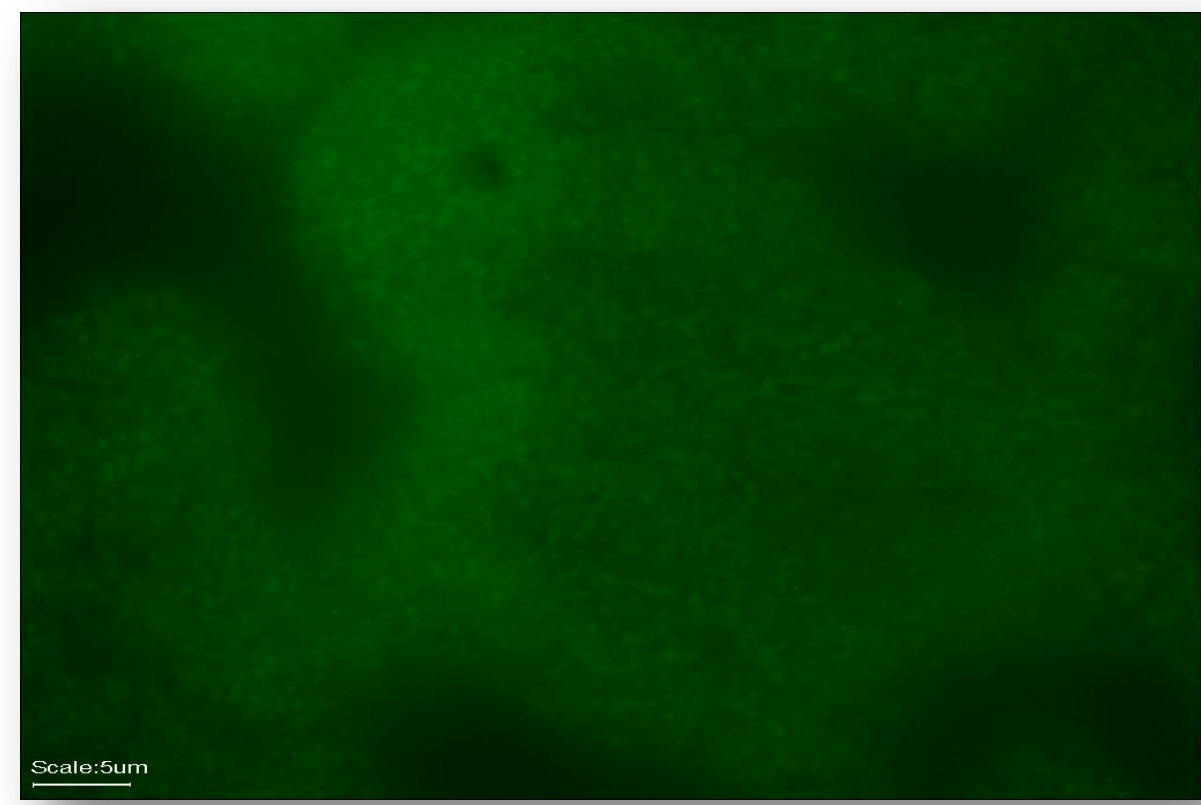

Figure 14. Visualization of Arthrobacter spp. Population 1 T0.25 on the surface of glass coverslips. 


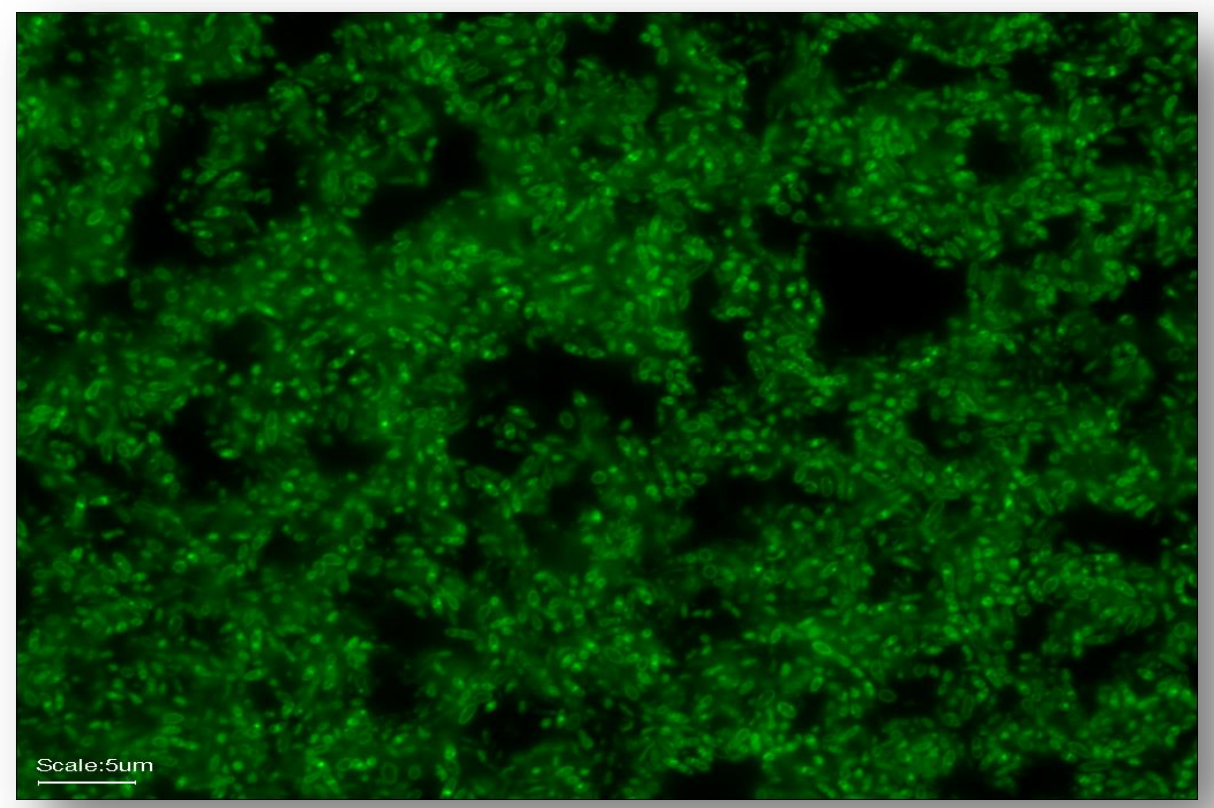

Figure 15. Visualization of Arthrobacter spp. Population 2 T0.25 on the surface of glass coverslips.

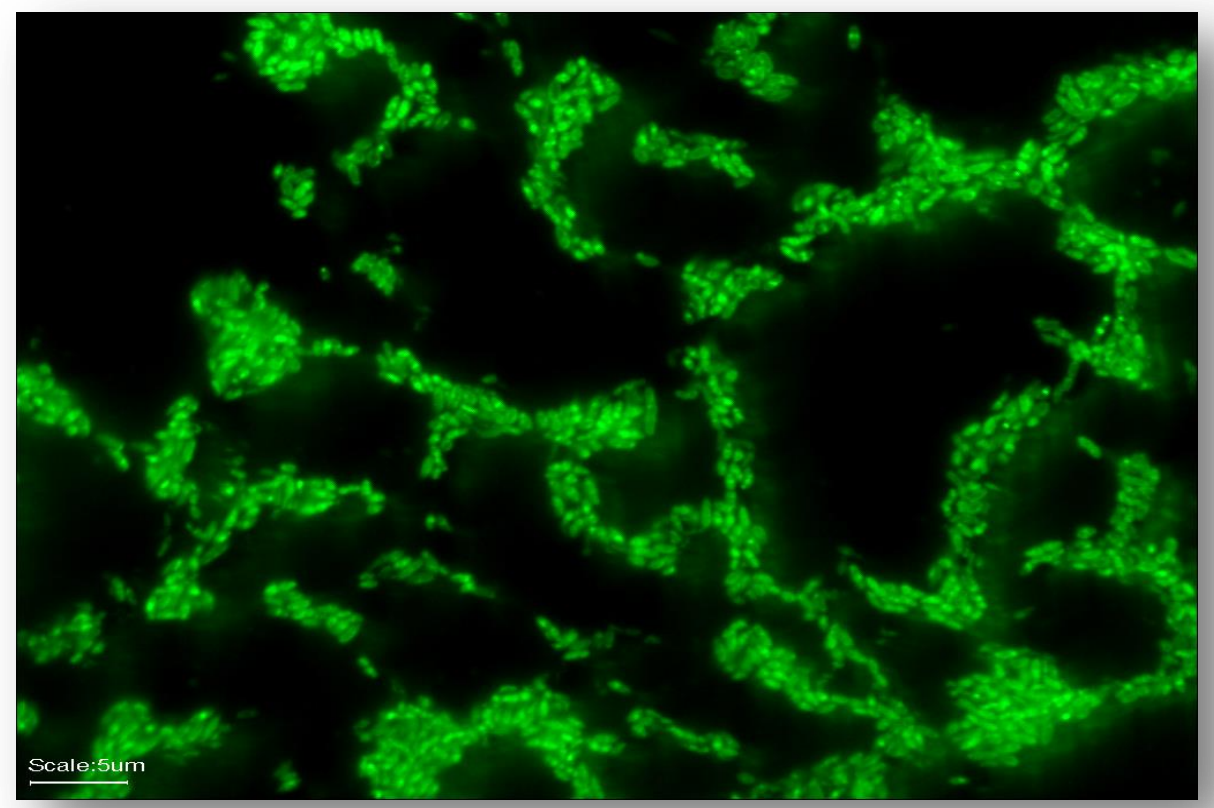

Figure 16. Visualization of Arthrobacter spp. Population 3 T0.25 on the surface of glass coverslips. 


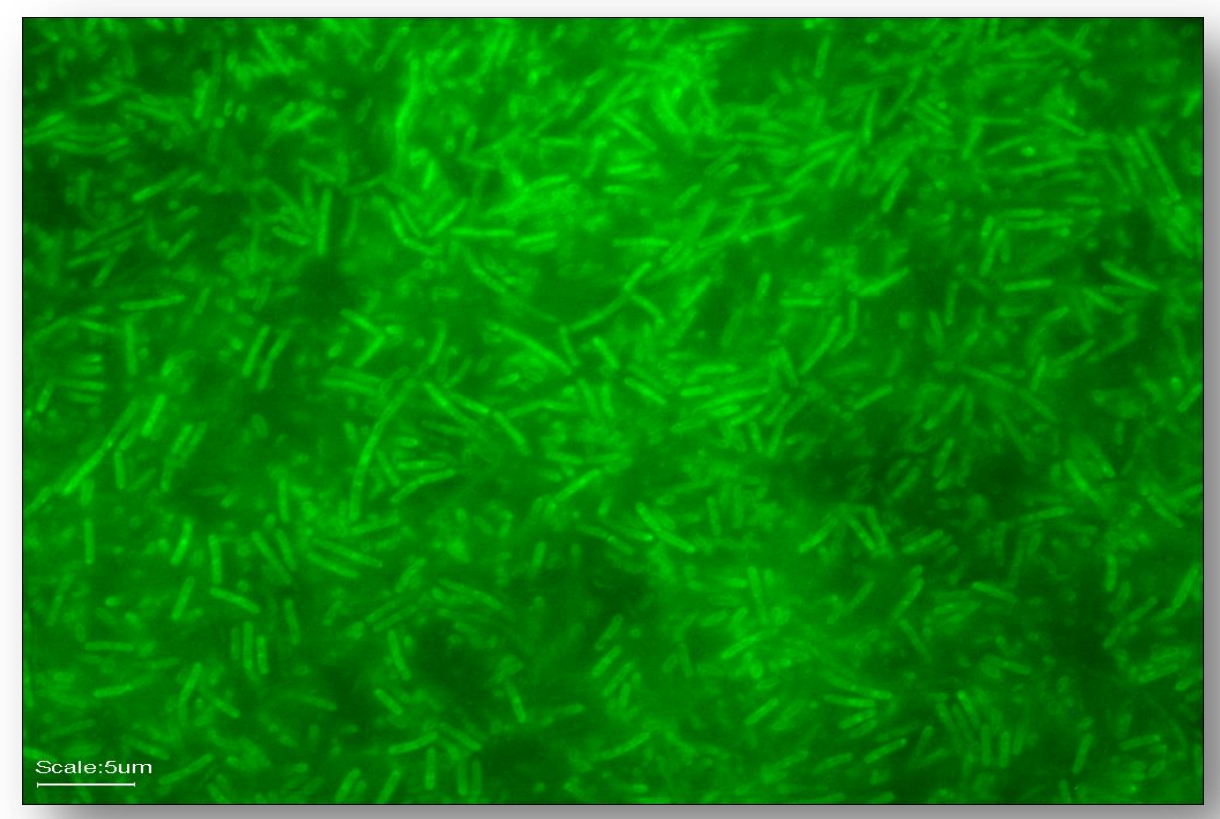

Figure 17. Visualization of $P$. stutzeri Population 1 T0.25 on the surface of glass coverslips.

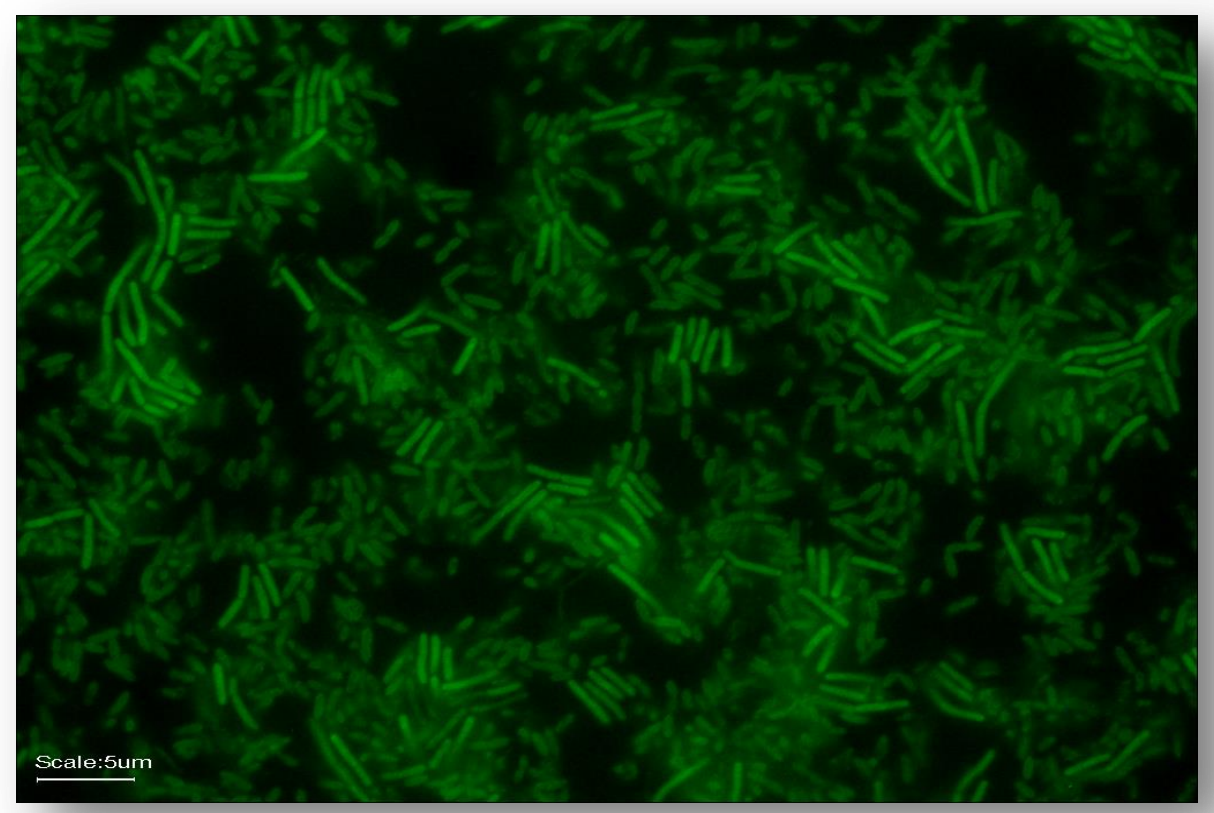

Figure 18. Visualization of $P$. stutzeri Population 2 T0.25 on the surface of glass coverslips. 


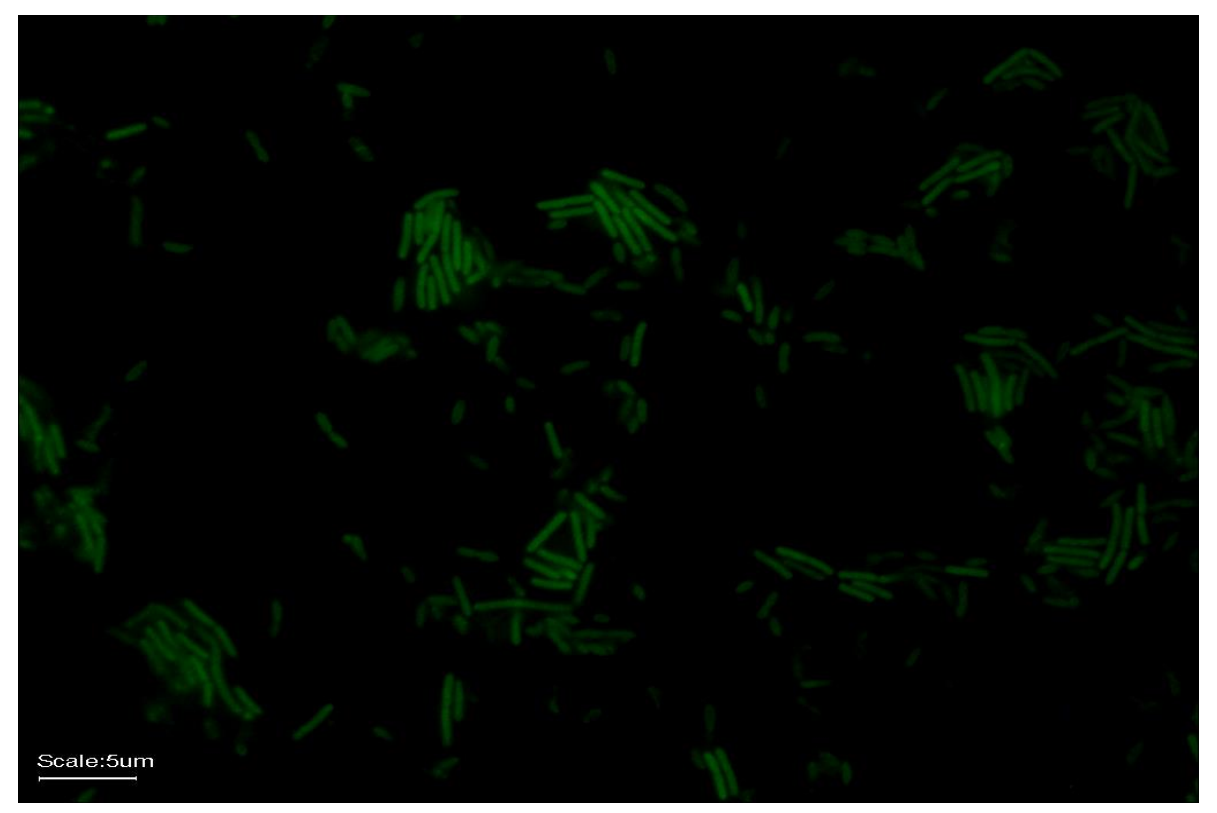

Figure 19. Visualization of $P$. stutzeri Population 3 T0.25 on the surface of glass coverslips. 


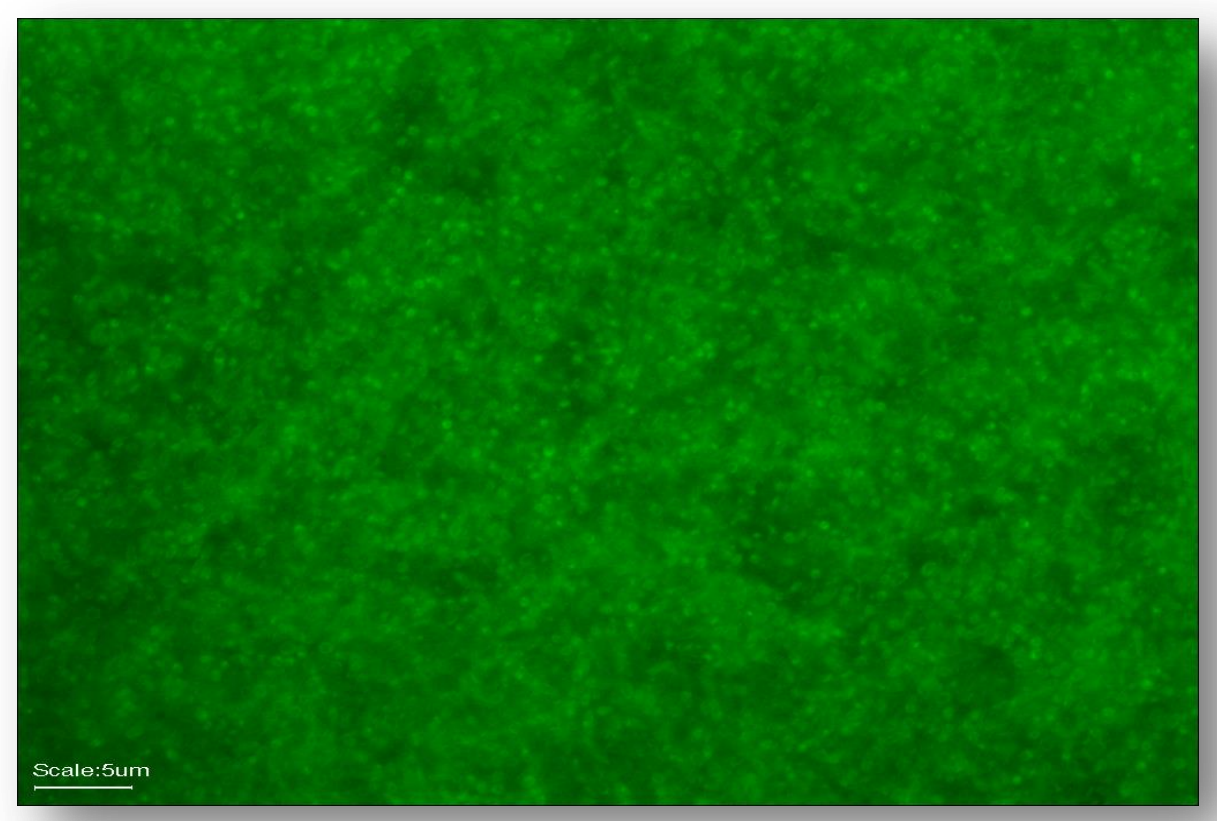

Figure 20. Visualization of Arthrobacter spp. Population 1 on the surface of glass coverslips.

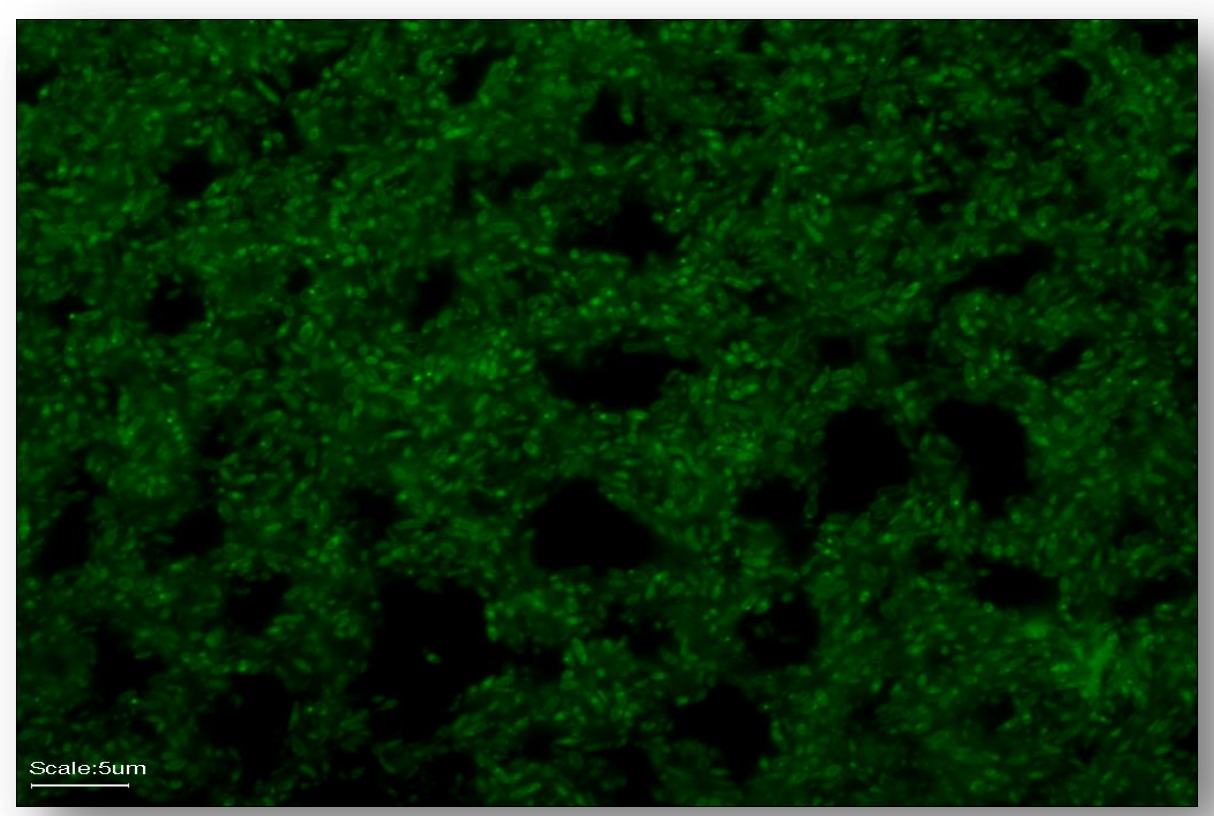

Figure 21. Visualization of Arthrobacter spp. Population 2 T1 on the surface of glass coverslips. 


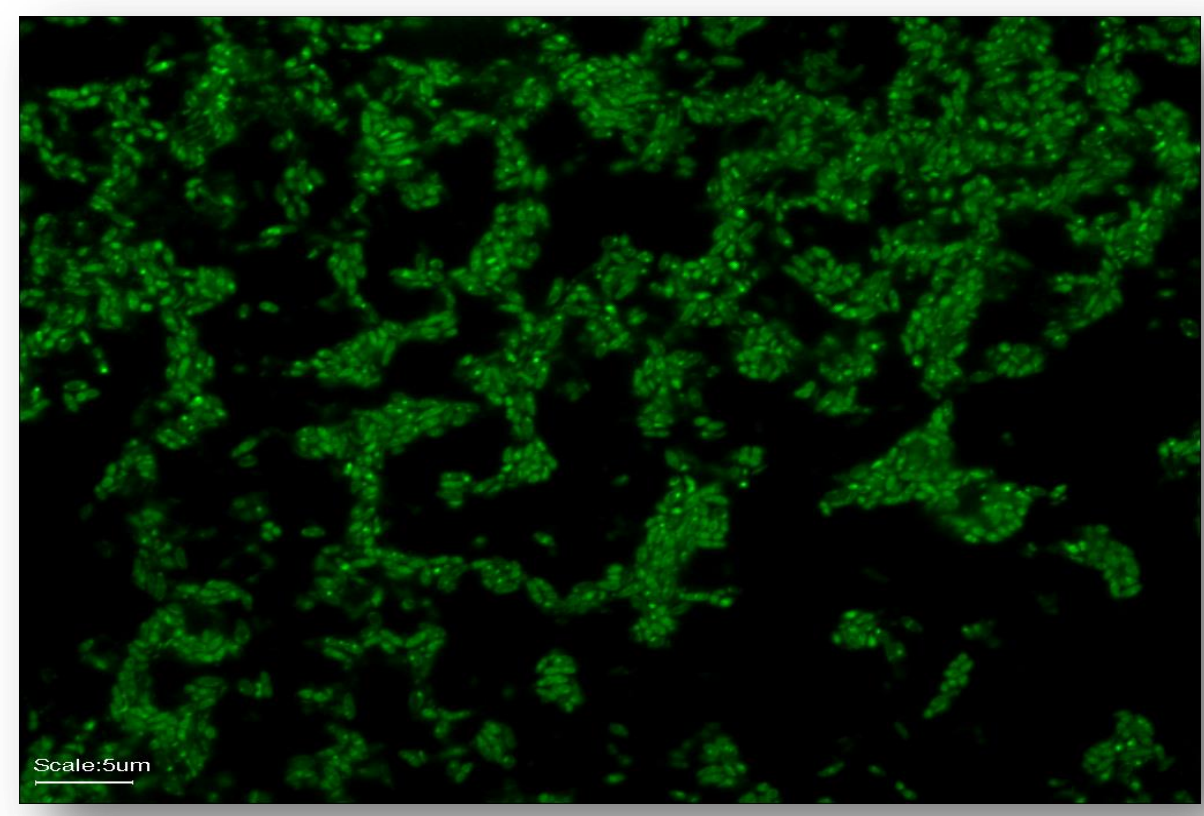

Figure 22. Visualization of Arthrobacter spp. Population 3 T1 on the surface of glass coverslips. 


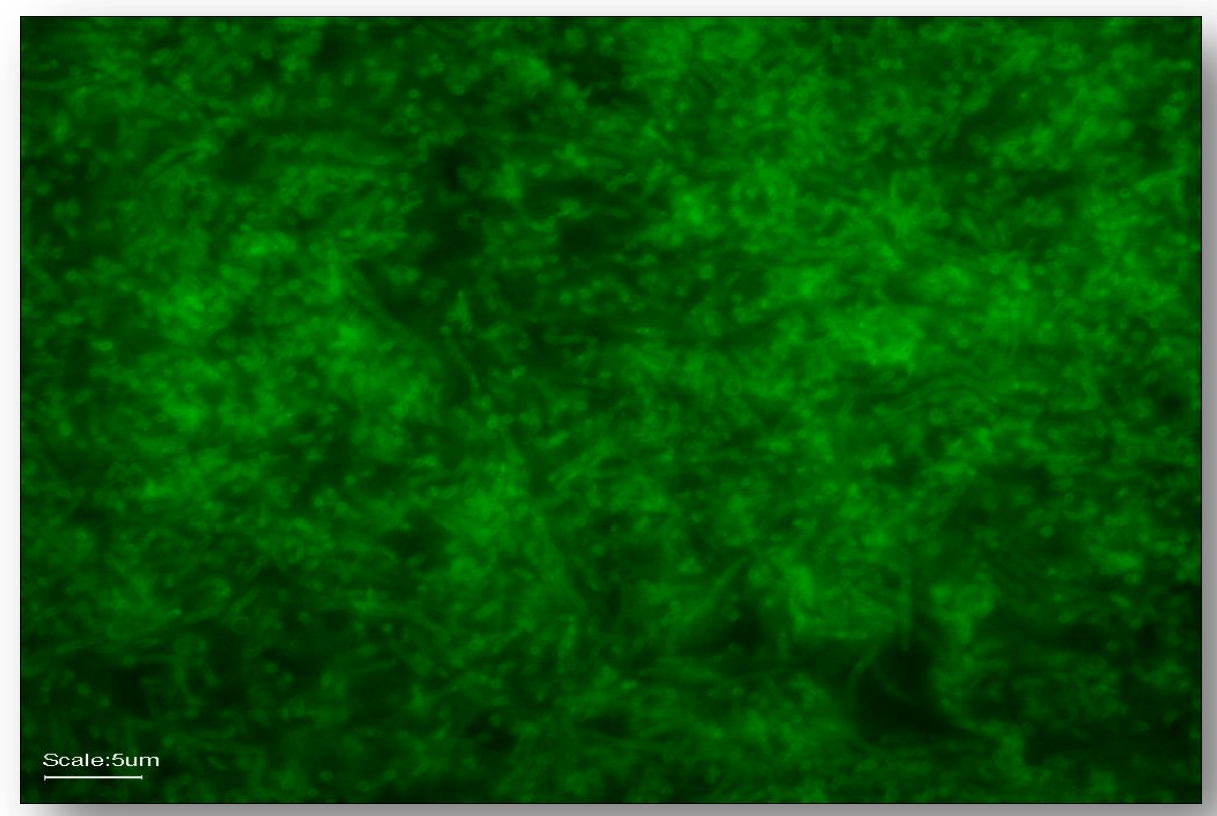

Figure 23. Visualization of $P$. stutzeri Population 1 T1 on the surface of glass coverslips.

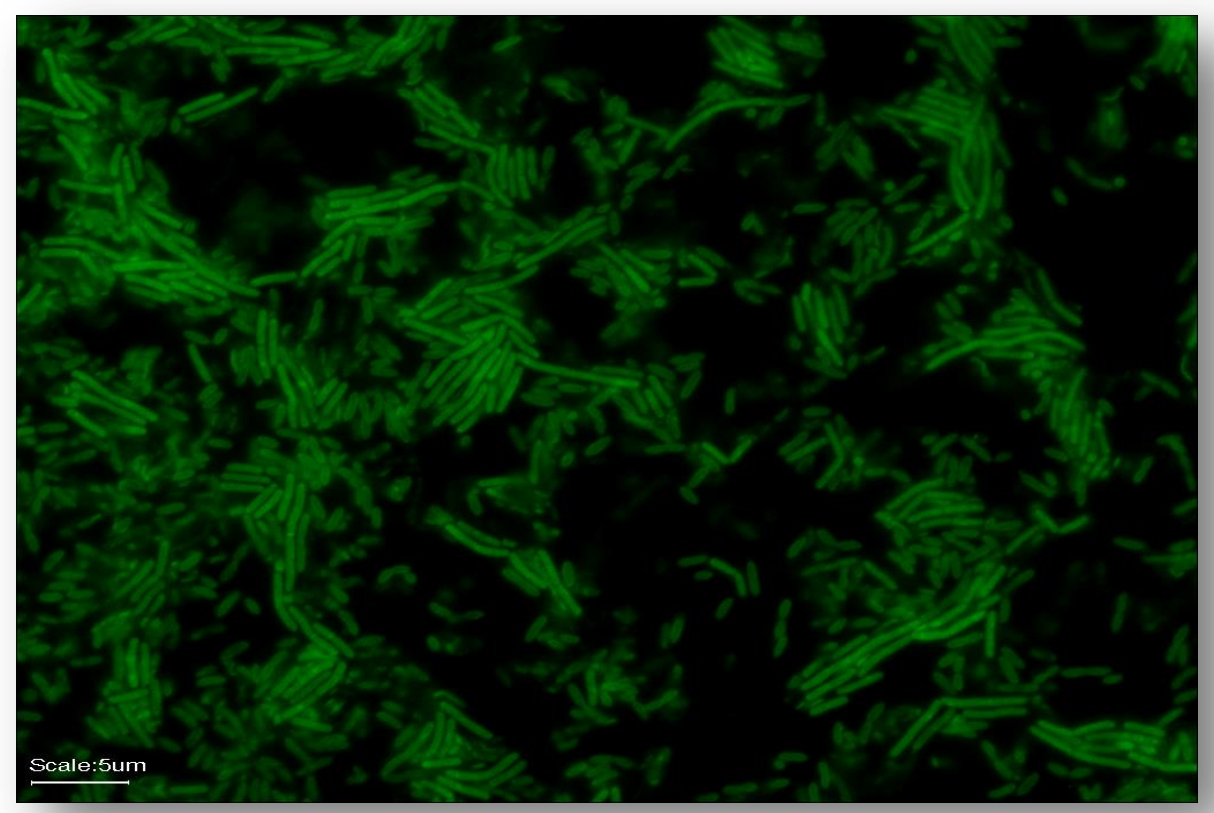

Figure 24. Visualization of $P$. stutzeri Population 2 T1 on the surface of glass coverslips. 


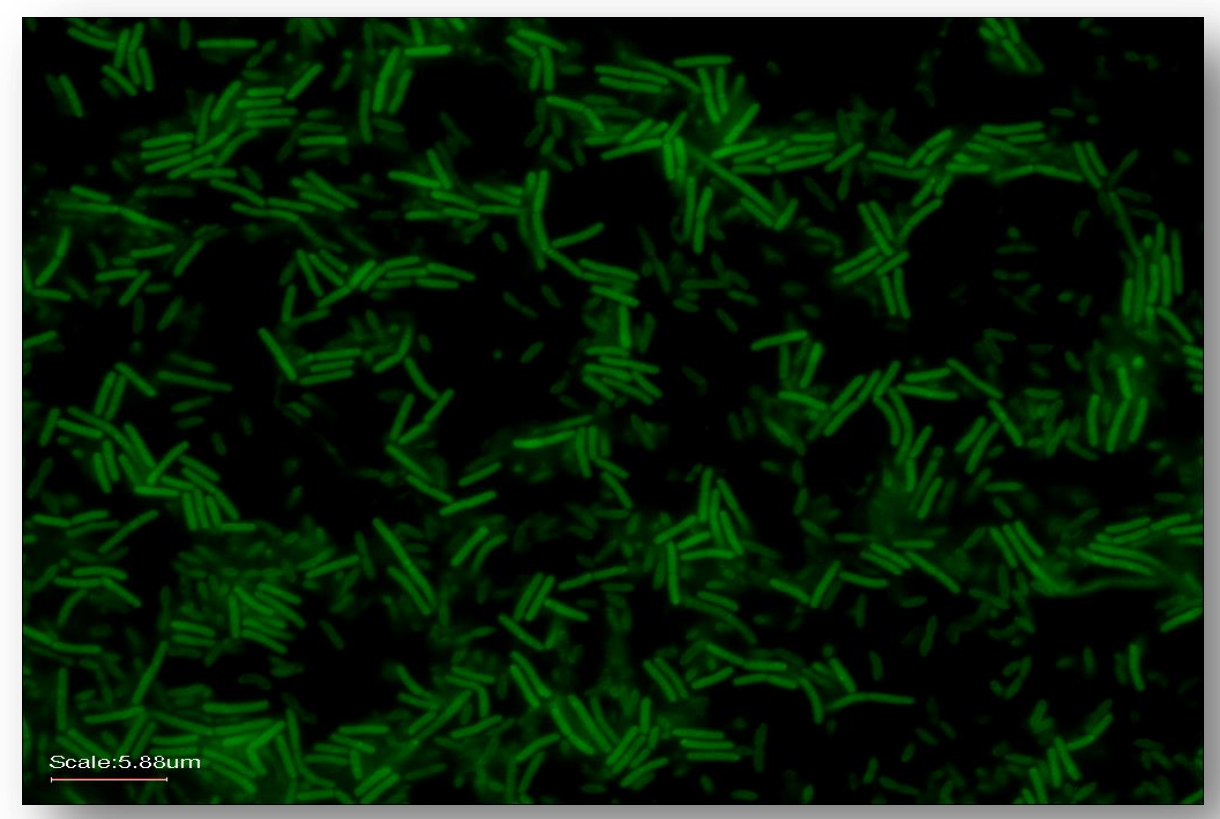

Figure 25. Visualization of $\boldsymbol{P}$. stutzeri Population 3 T1 on the surface of glass coverslips. 


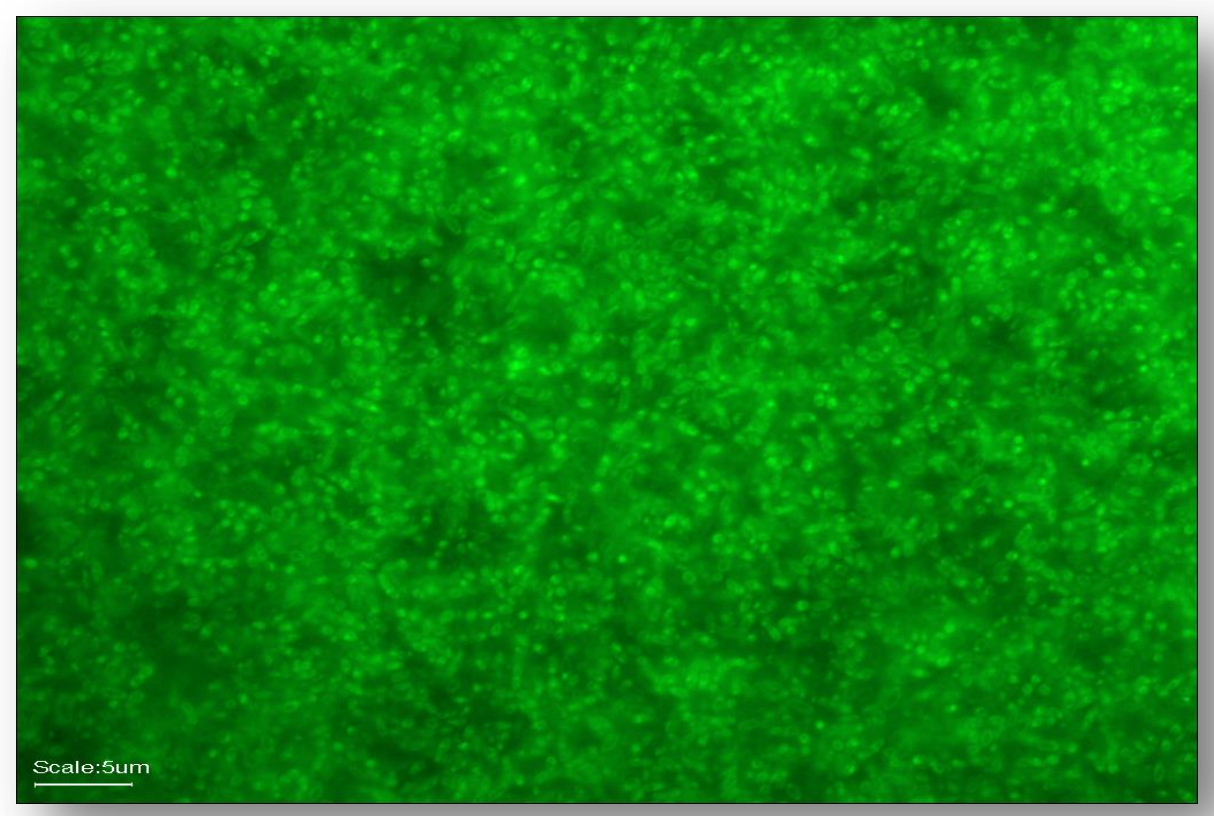

Figure 26. Visualization of Arthrobacter spp. Population 1 T3 on the surface of glass coverslips.

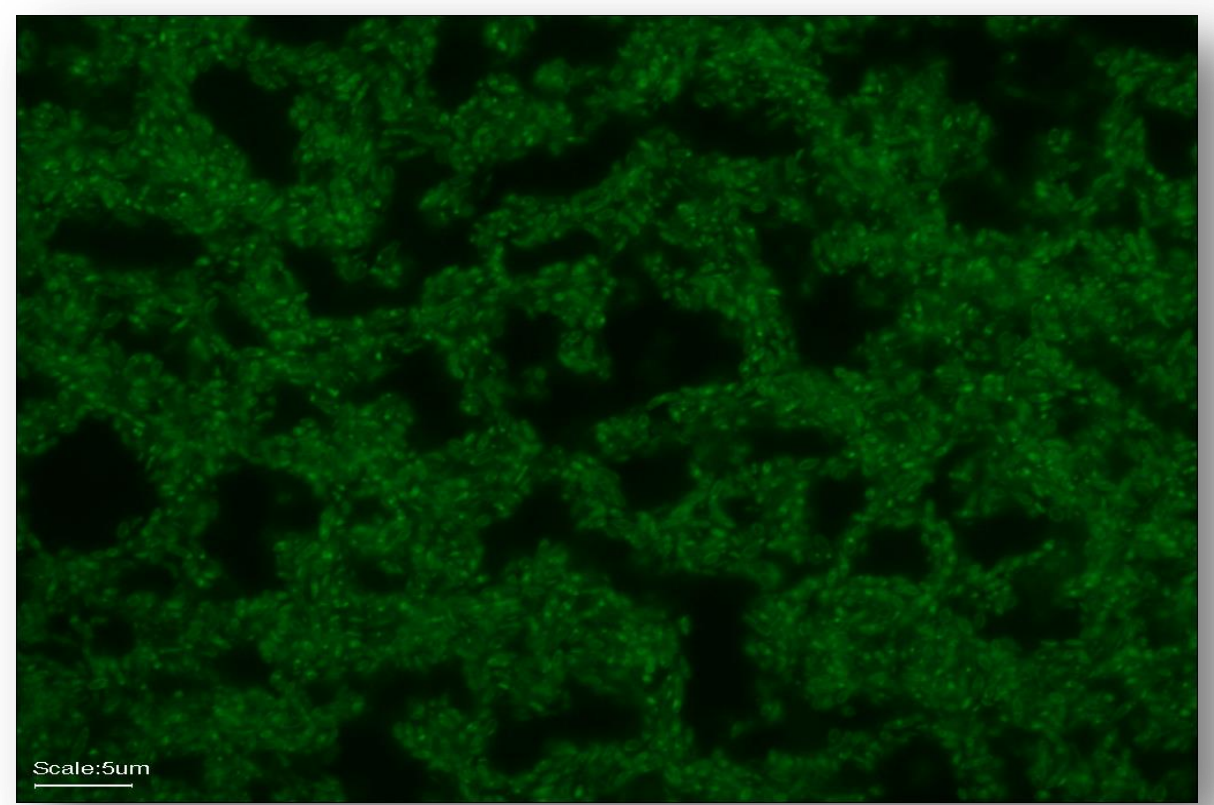

Figure 27. Visualization of Arthrobacter spp. Population 2 T3 on the surface of glass coverslips. 


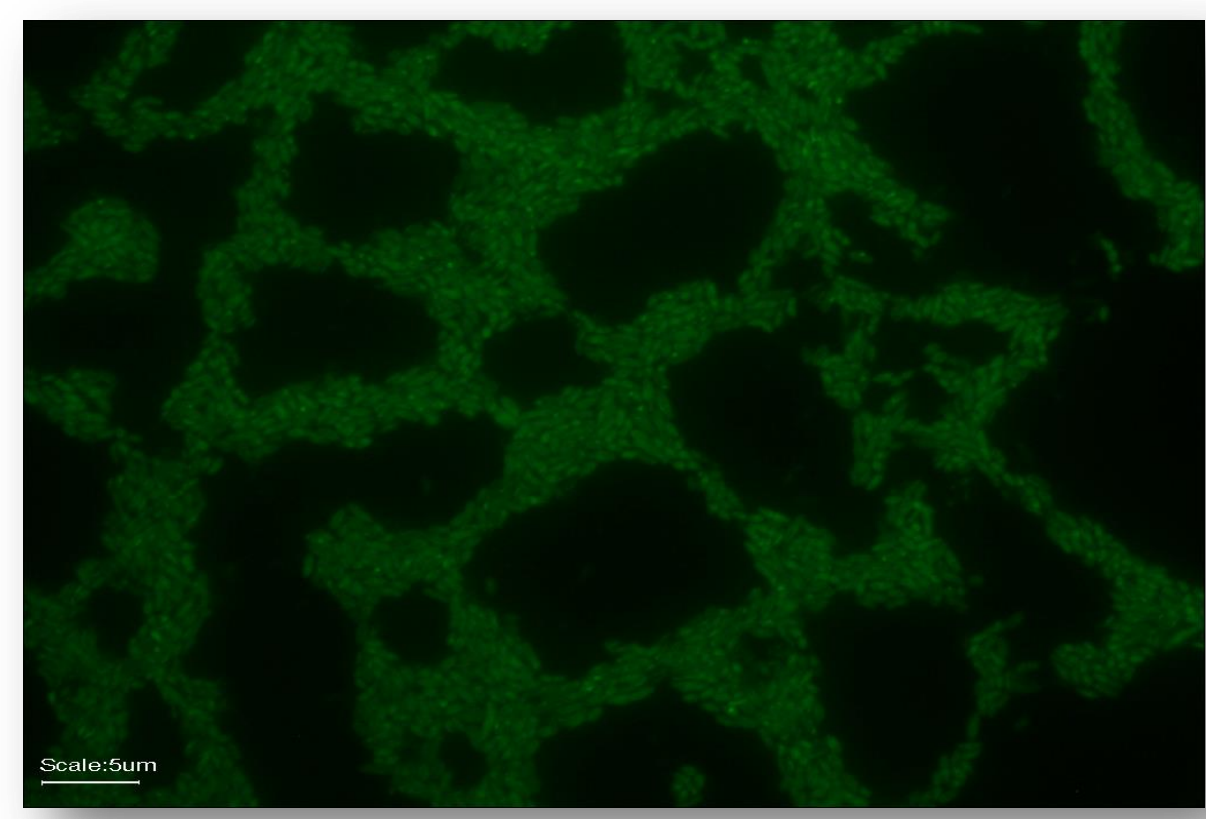

Figure 28. Visualization of Arthrobacter spp. Population 3 T3 on the surface of glass coverslips. 


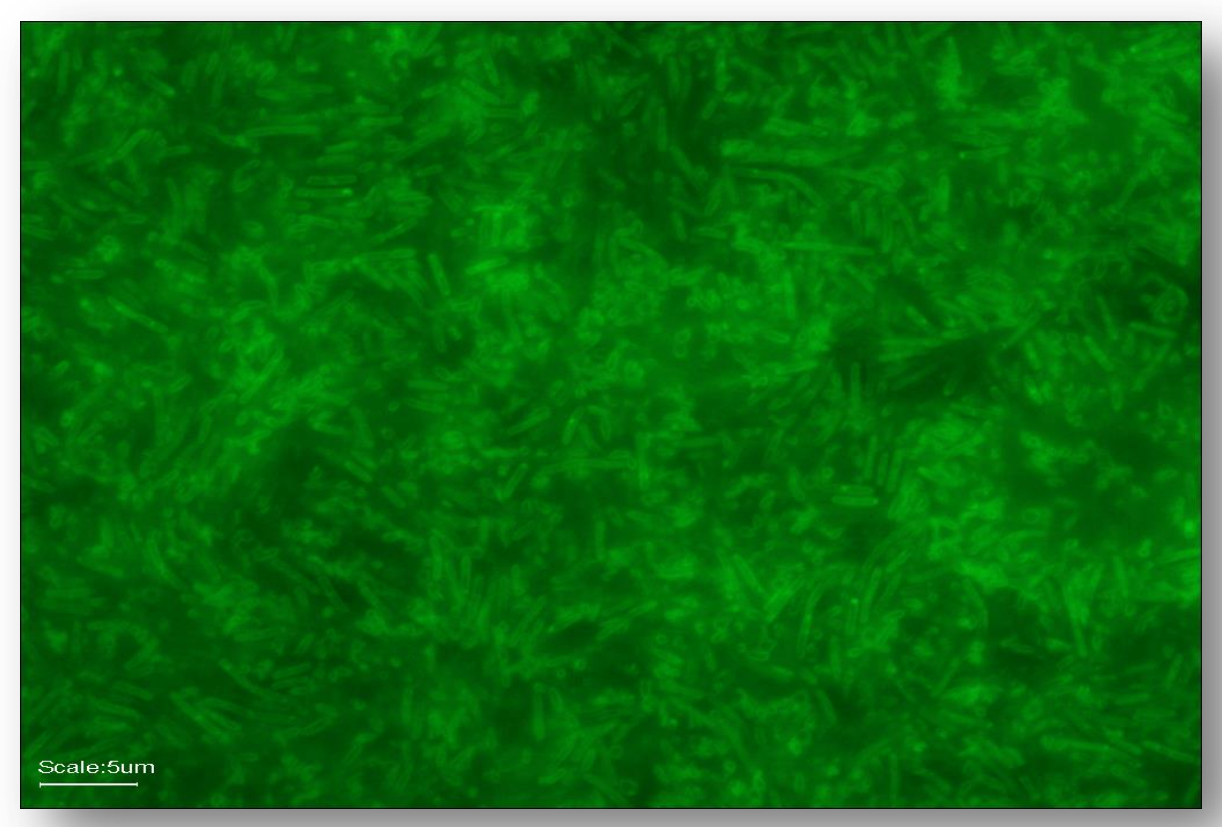

Figure 29. Visualization of $\boldsymbol{P}$. stutzeri Population 1 T3 on the surface of glass coverslips.

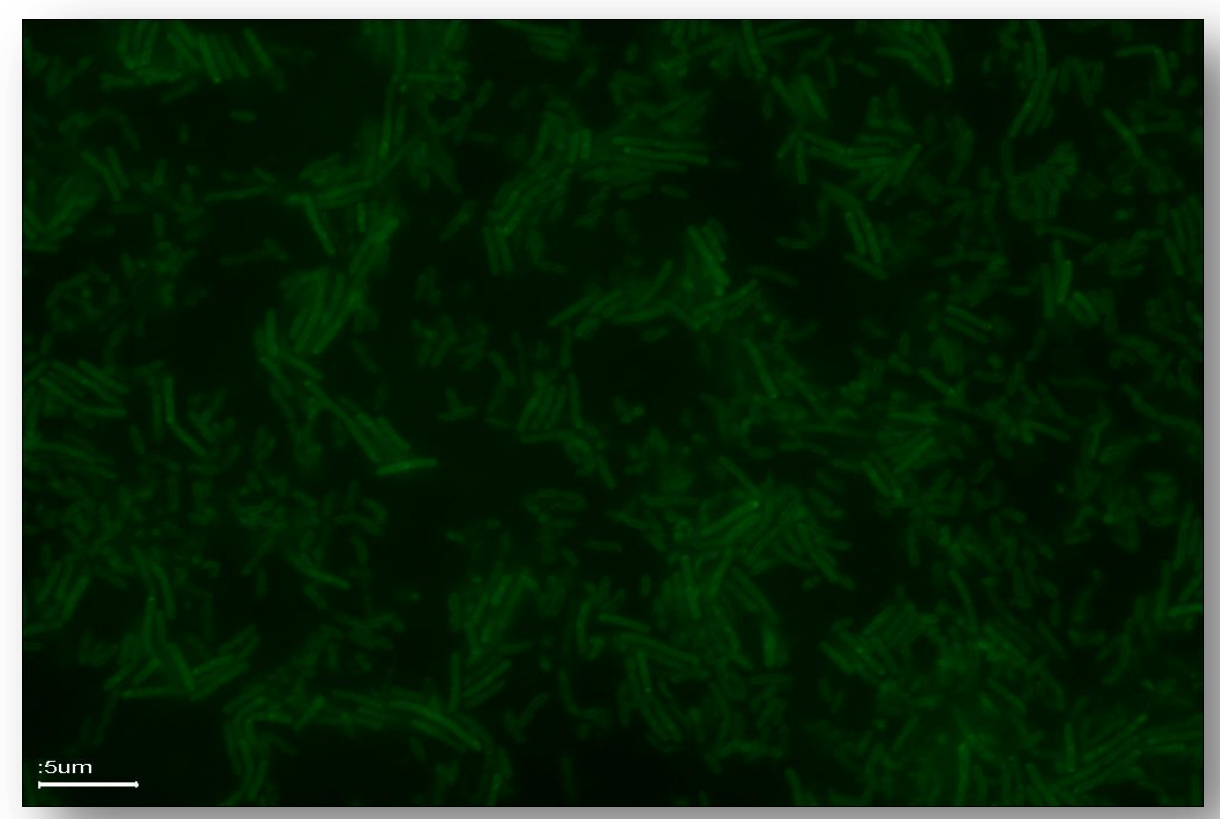

Figure 30. Visualization of $\boldsymbol{P}$. stutzeri Population 2 T3 on the surface of glass coverslips. 


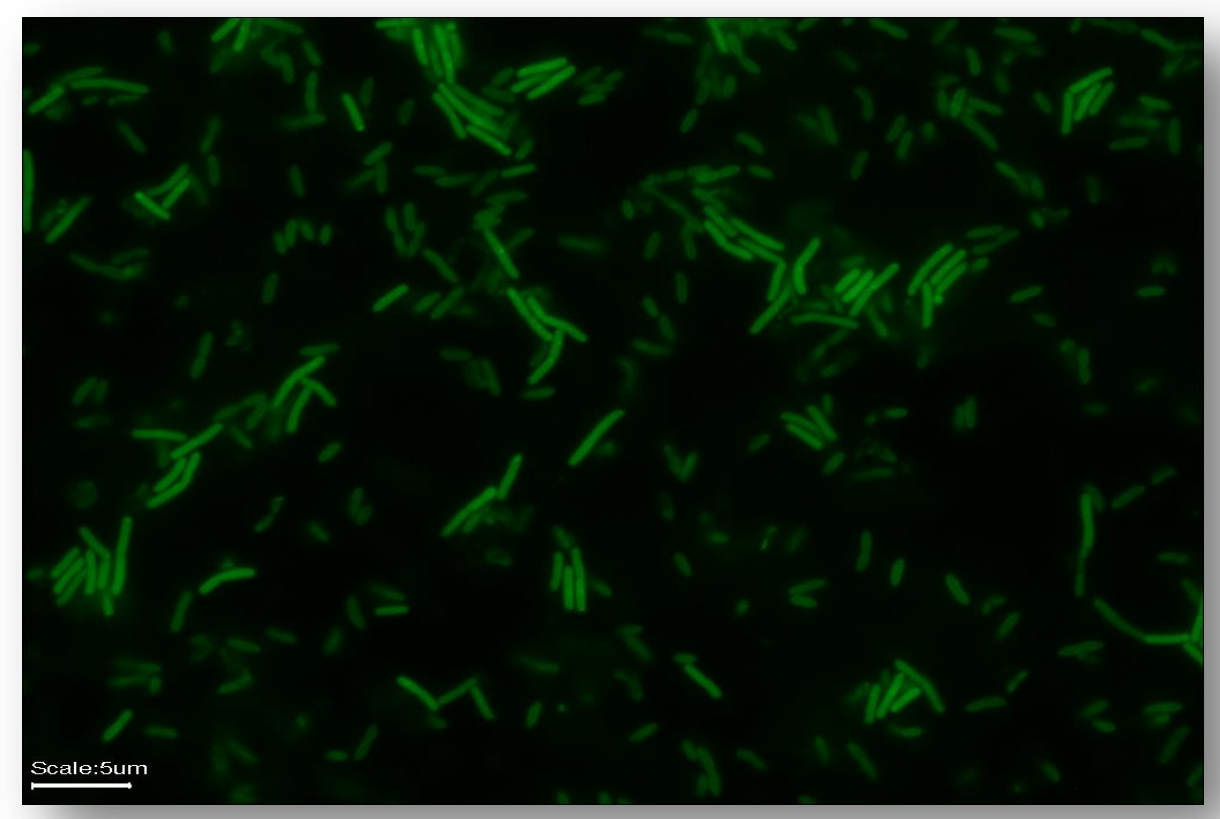

Figure 31. Visualization of $P$. stutzeri Population 3 T3 on the surface of glass coverslips. 


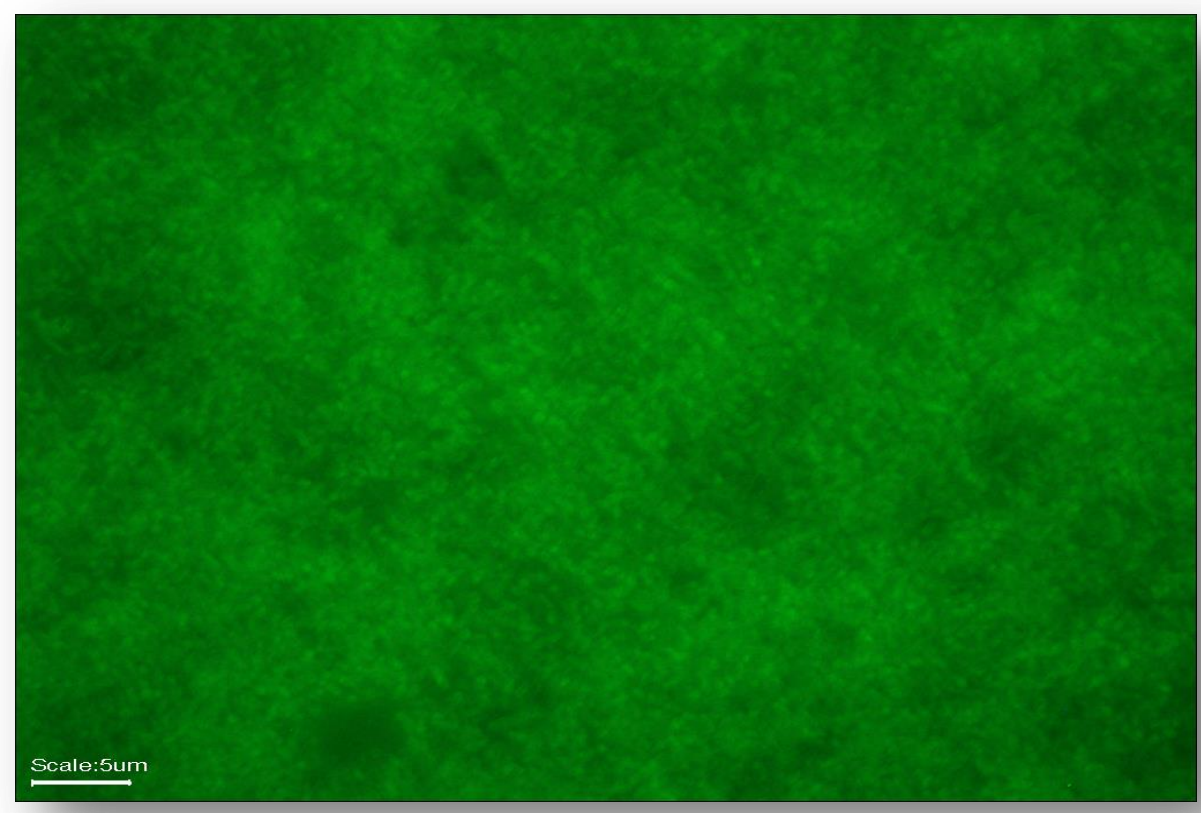

Figure 32. Visualization of Arthrobacter spp. Population 1 T6 on the surface of glass coverslips.

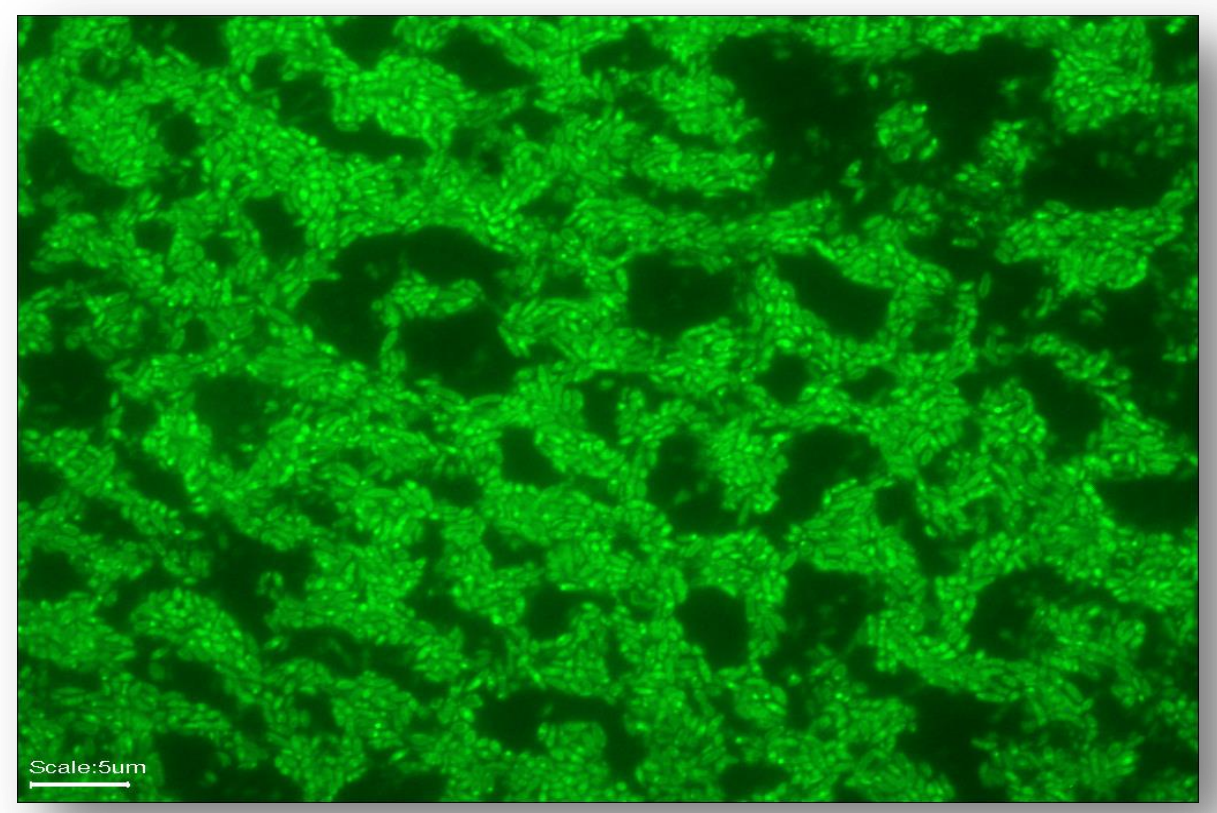

Figure 33. Visualization of Arthrobacter spp. Population 2 T6 on the surface of glass coverslips. 


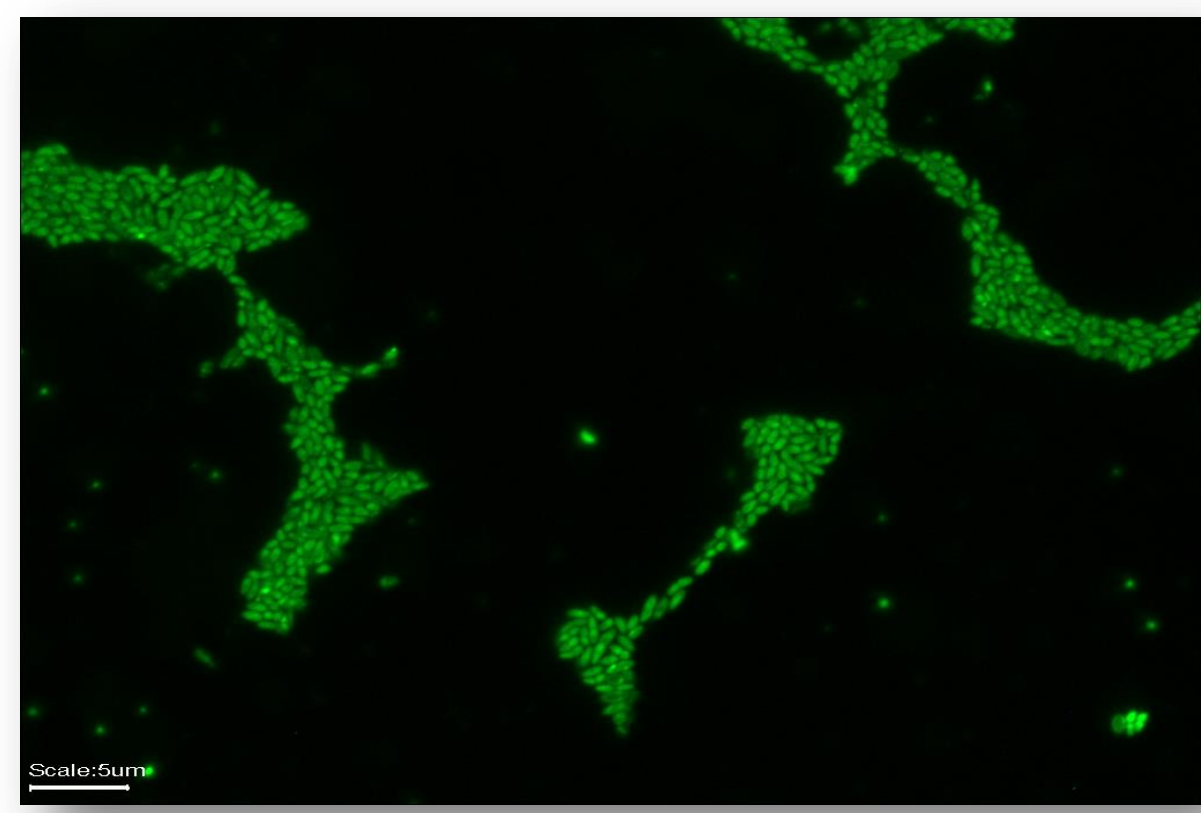

Figure 34. Visualization of Arthrobacter spp. Population 3 T6 on the surface of glass coverslips. 


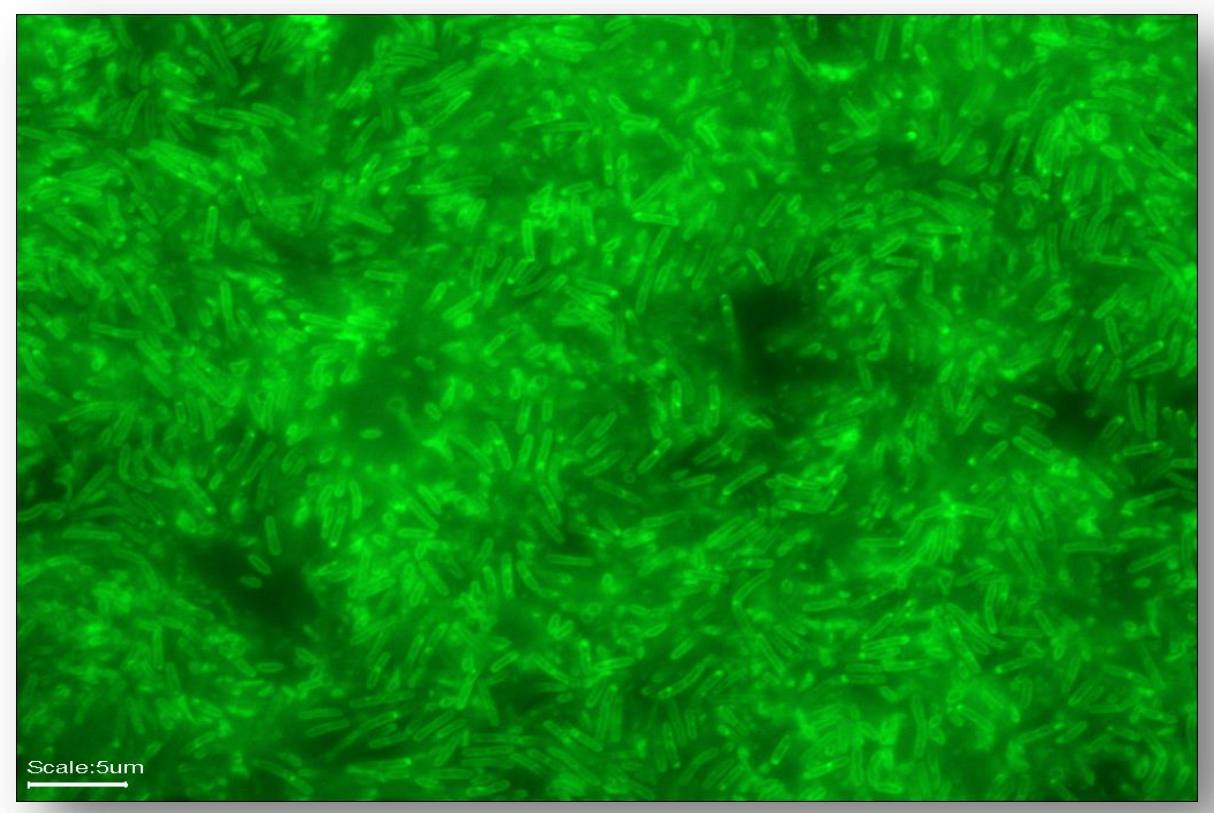

Figure 35. Visualization of $P$. stutzeri Population 1 T6 on the surface of glass coverslips.

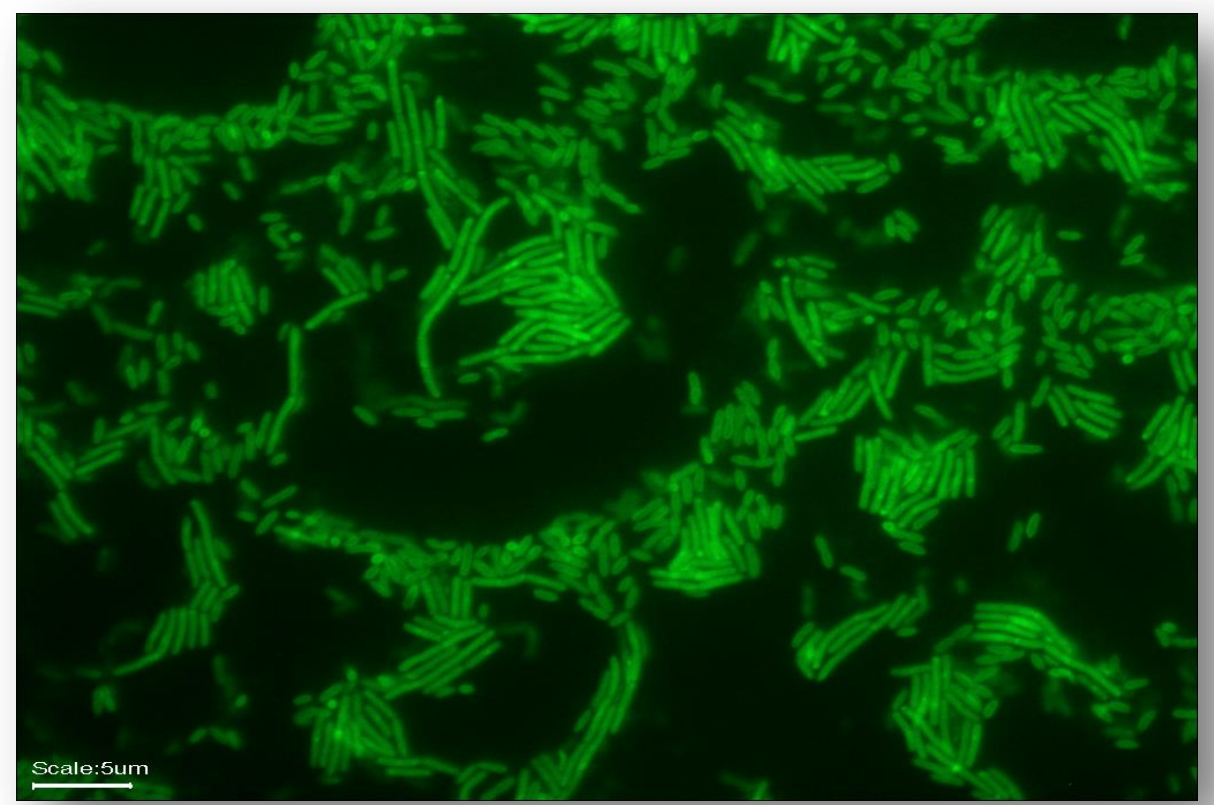

Figure 36. Visualization of $P$. stutzeri Population 2 T6 on the surface of glass coverslips. 


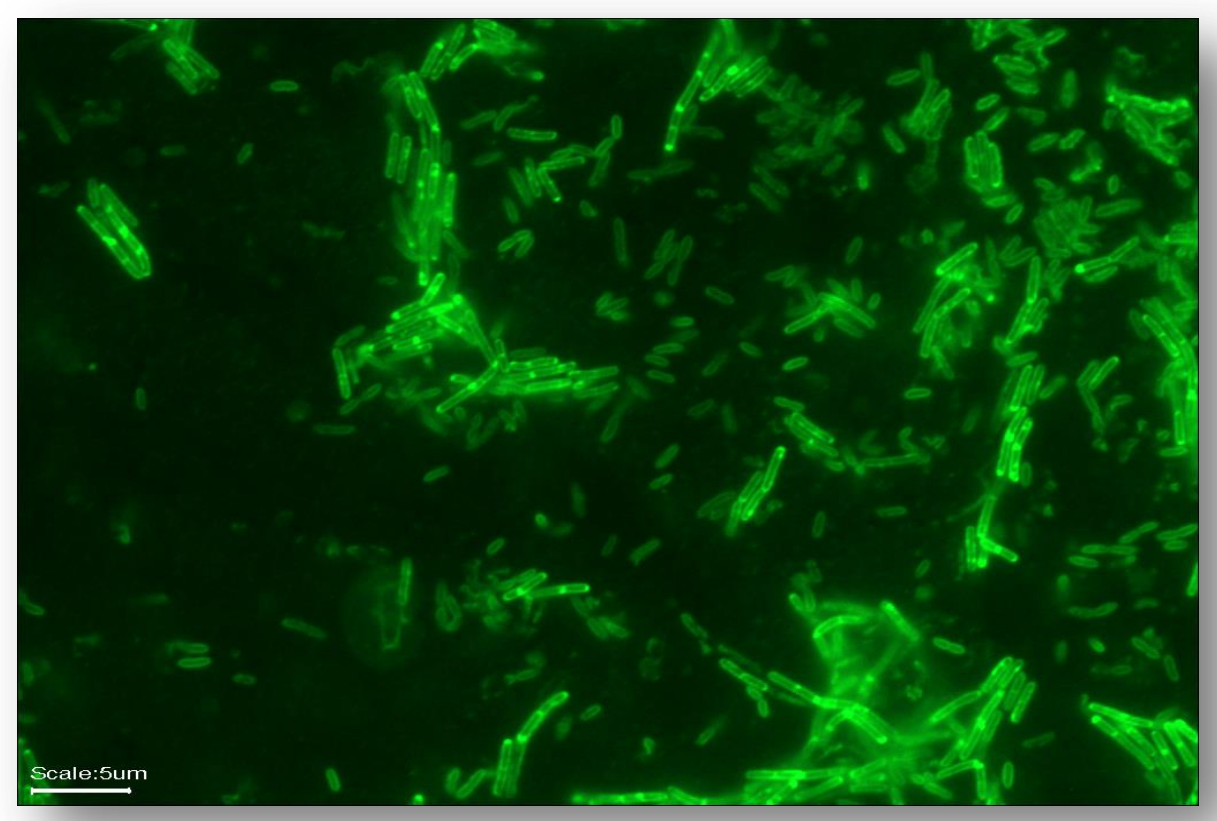

Figure 37. Visualization of $P$. stutzeri Population 3 T6 on the surface of glass coverslips. 


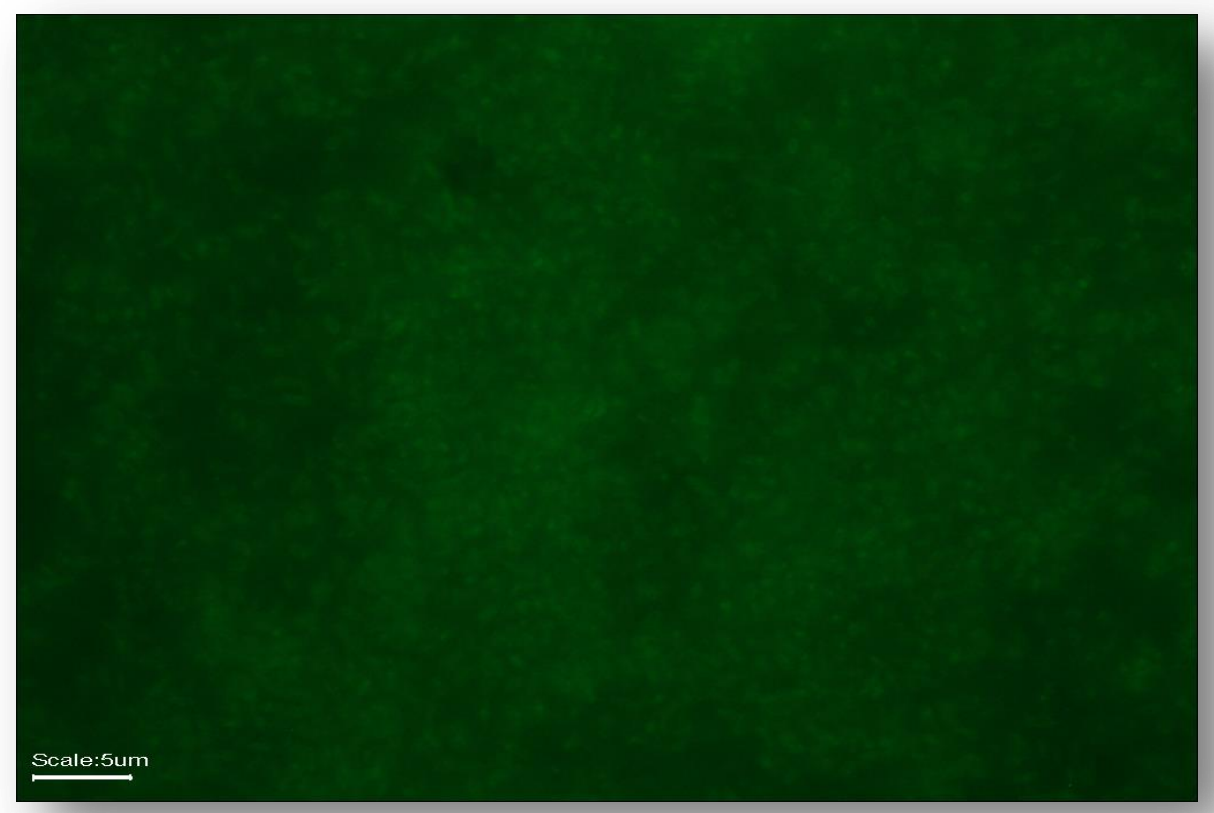

Figure 38. Visualization of Arthrobacter spp. Population 1 T8 on the surface of glass coverslips.

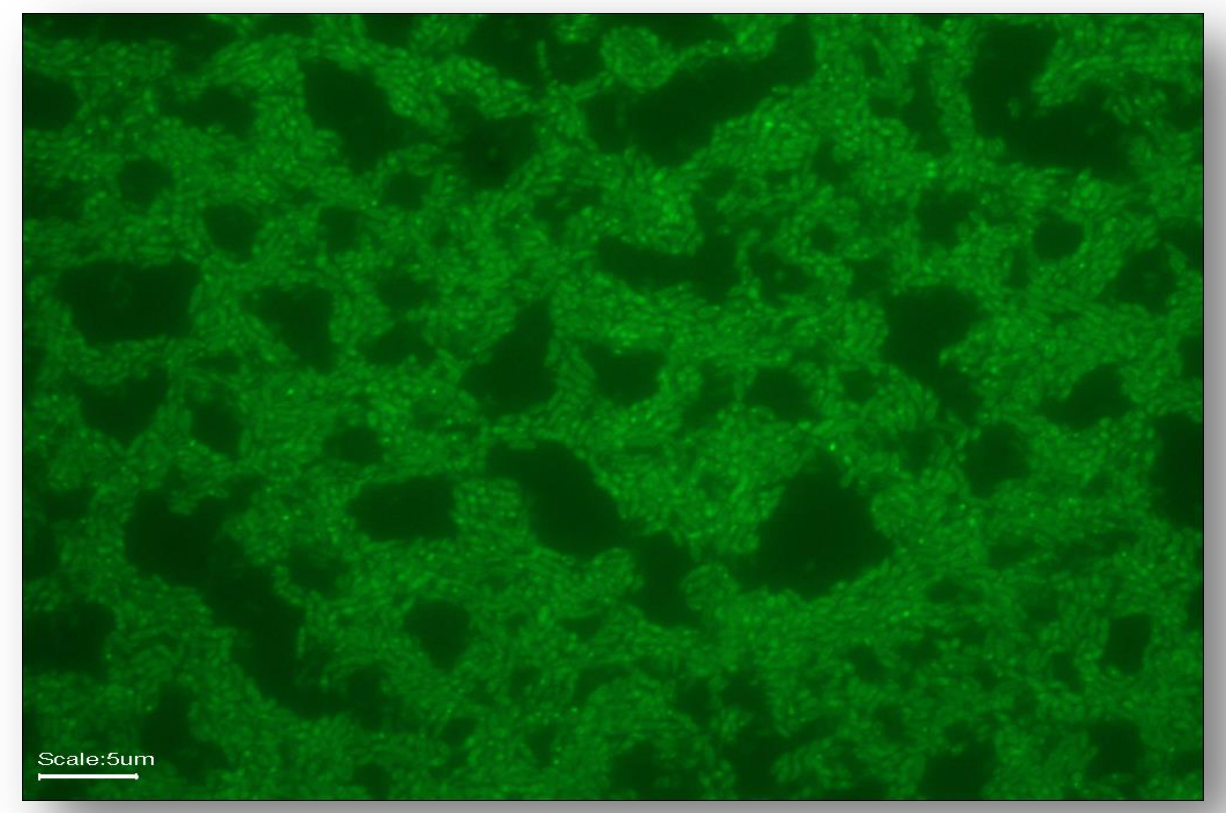

Figure 39. Visualization of Arthrobacter spp. Population 2 T8 on the surface of glass coverslips. 


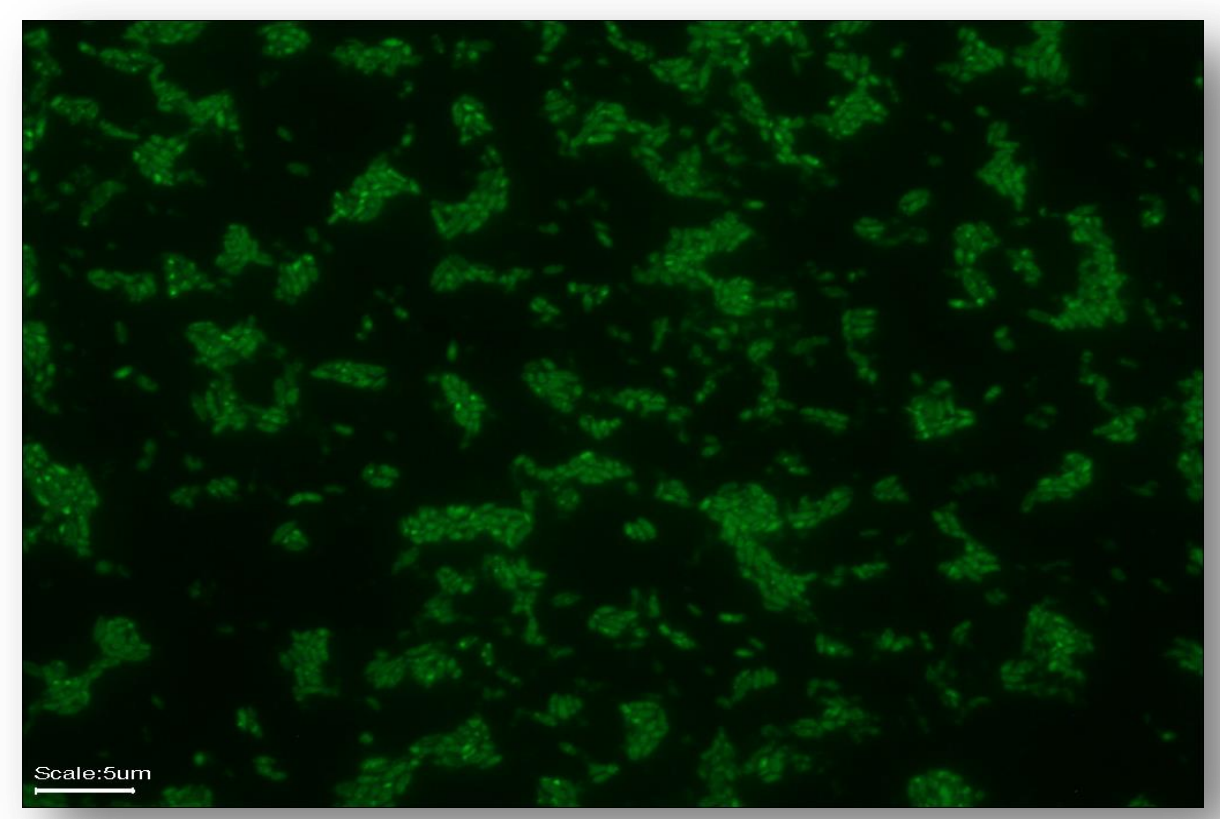

Figure 40. Visualization of Arthrobacter spp. Population 3 T8 on the surface of glass coverslips. 


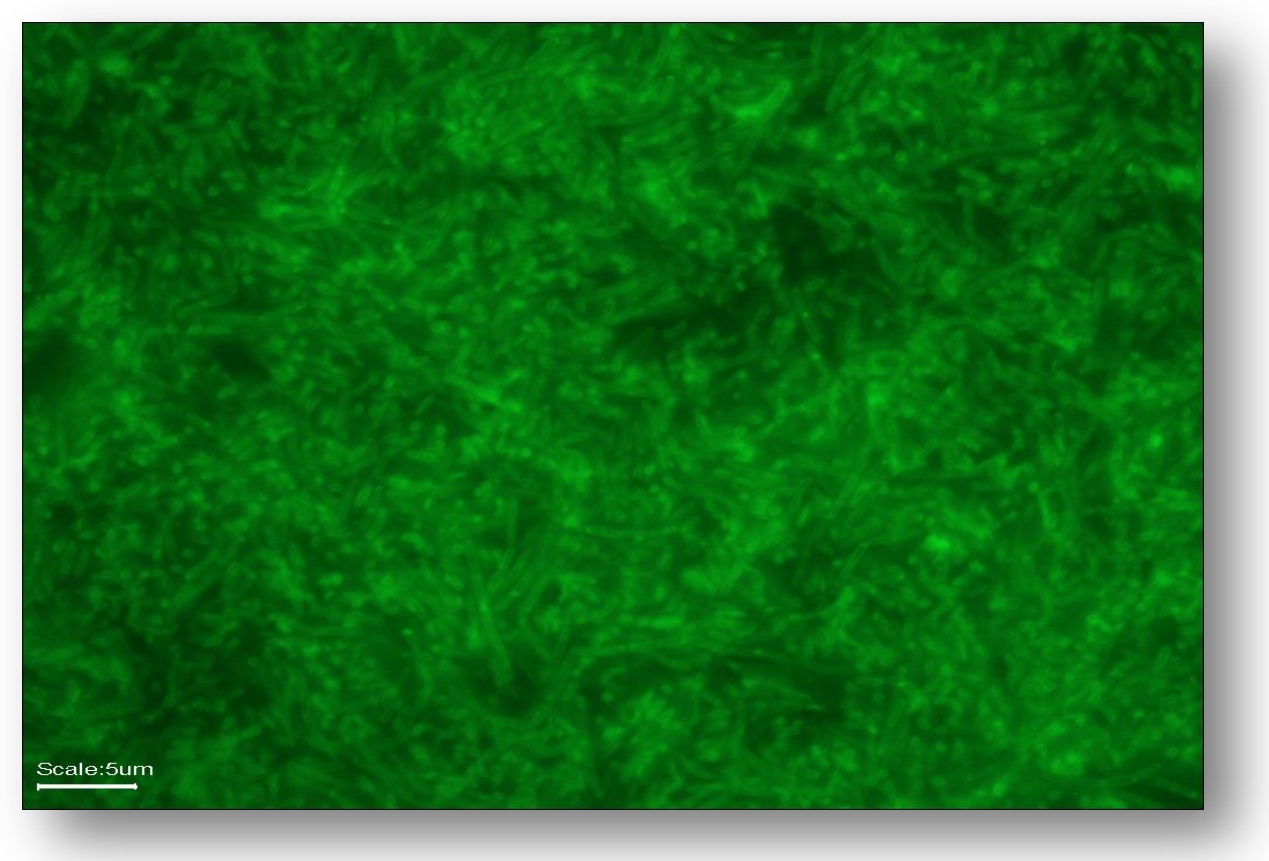

Figure 41. Visualization of $\boldsymbol{P}$. stutzeri Population 1 T8 on the surface of glass coverslips.

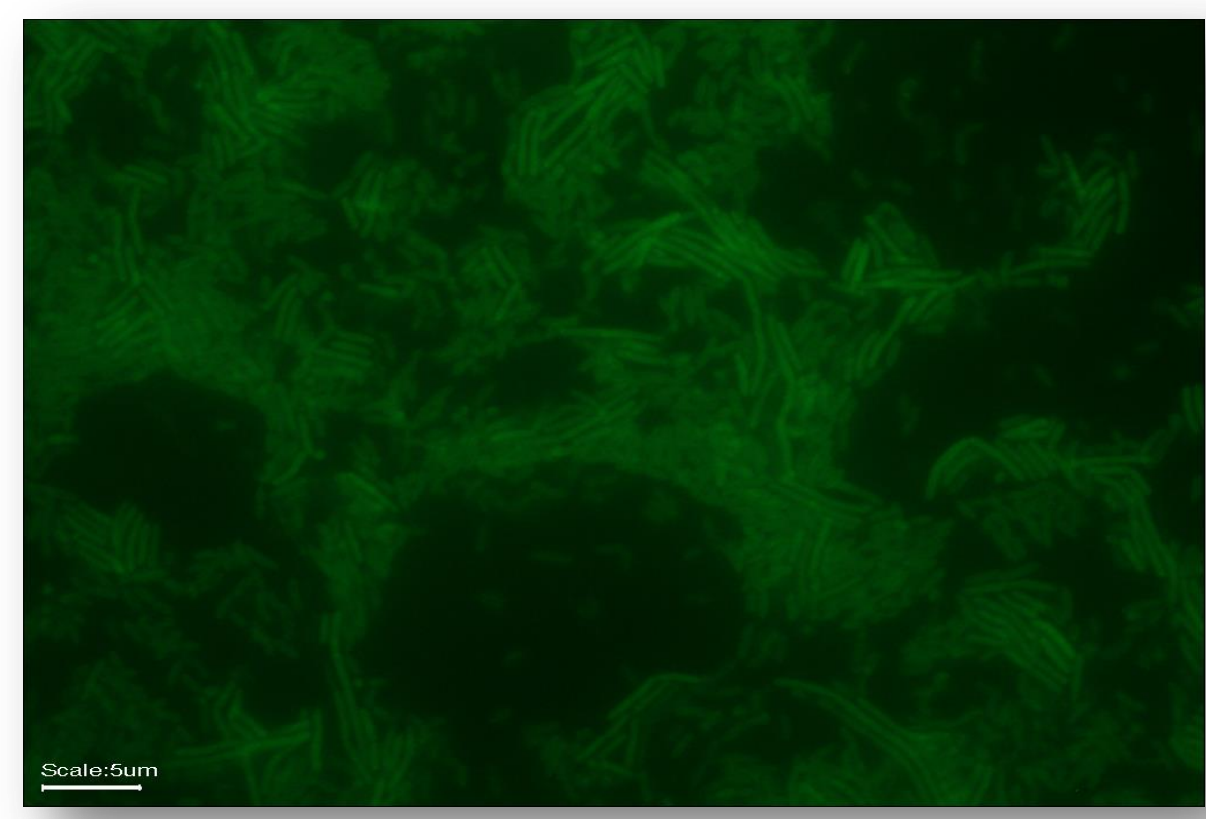

Figure 42. Visualization of $\boldsymbol{P}$. stutzeri Population 2 T8 on the surface of glass coverslips. 


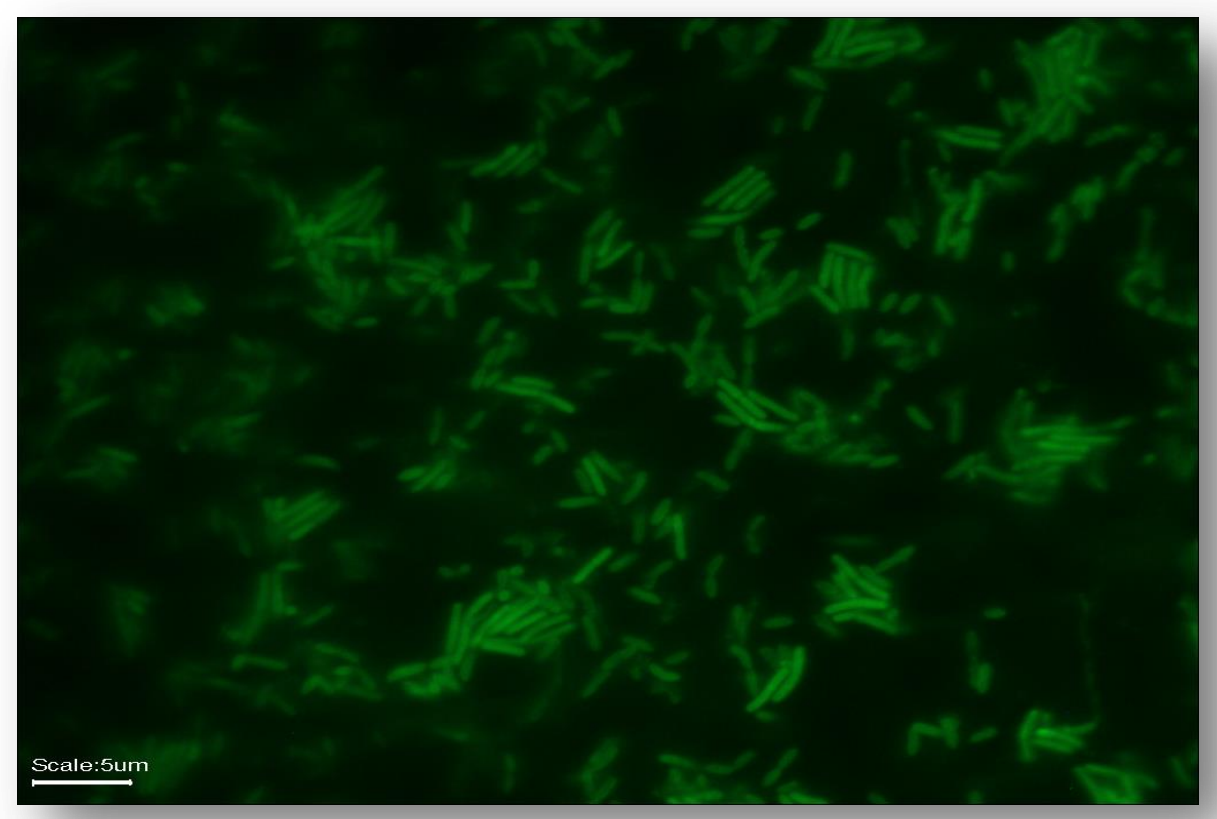

Figure 43. Visualization of $P$. stutzeri Population 3 T8 on the surface of glass coverslips. 


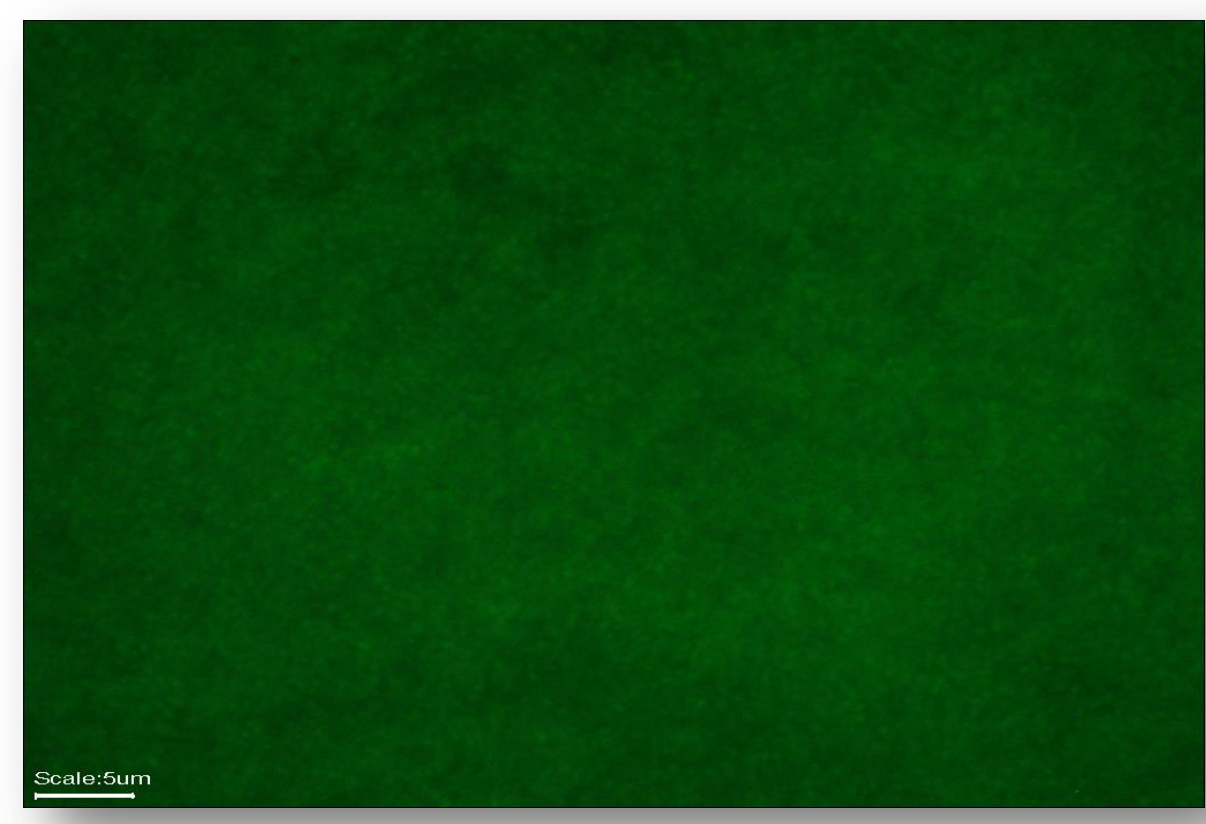

Figure 44. Visualization of Arthrobacter spp. Population 1 T15 on the surface of glass coverslips.

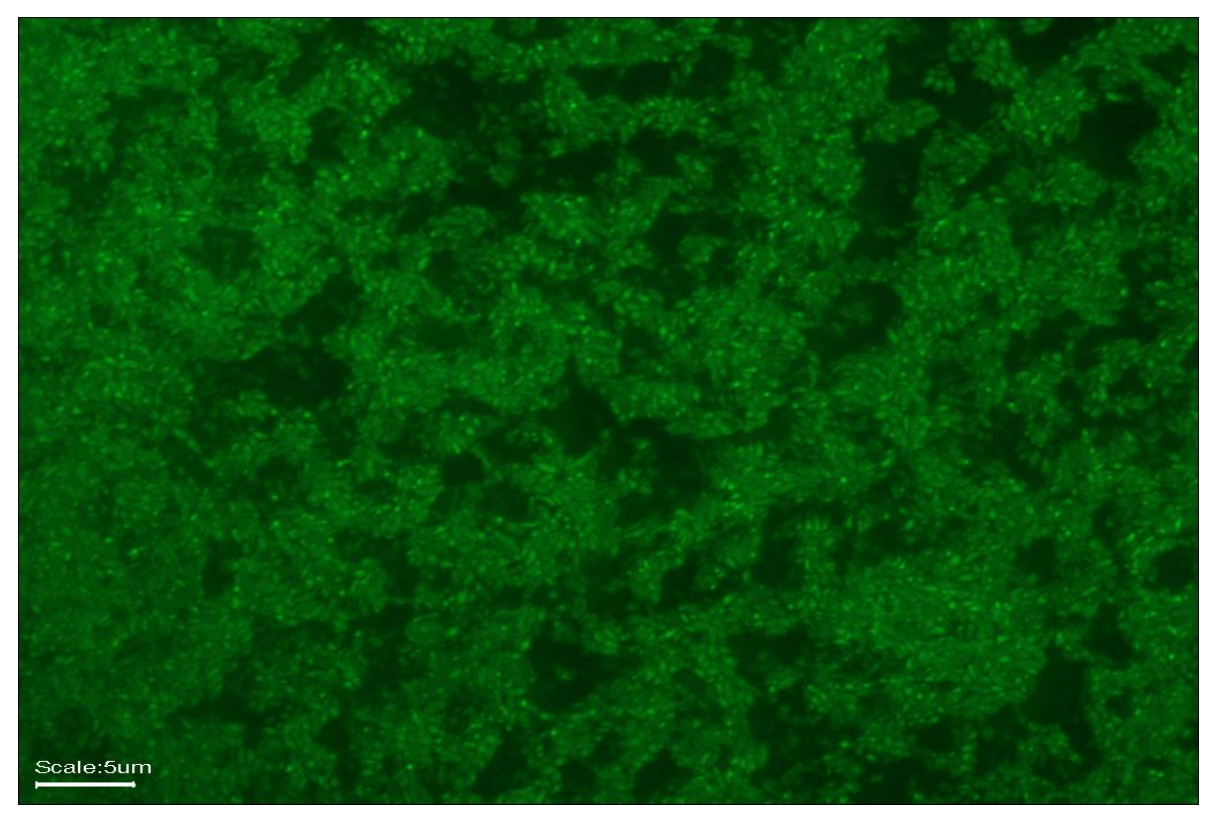

Figure 45. Visualization of Arthrobacter spp. Population 2 T15 on the surface of glass coverslips. 


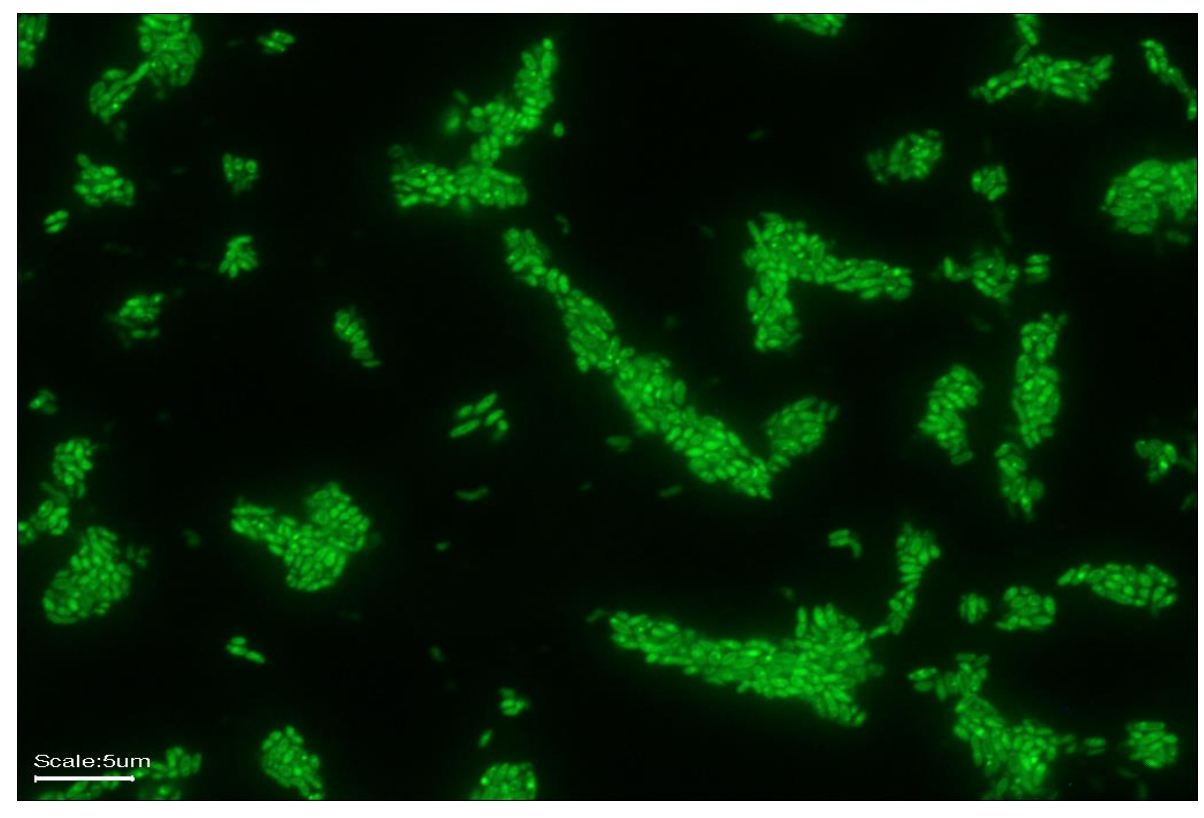

Figure 46. Visualization of Arthrobacter spp. Population 3 T15 on the surface of glass coverslips. 


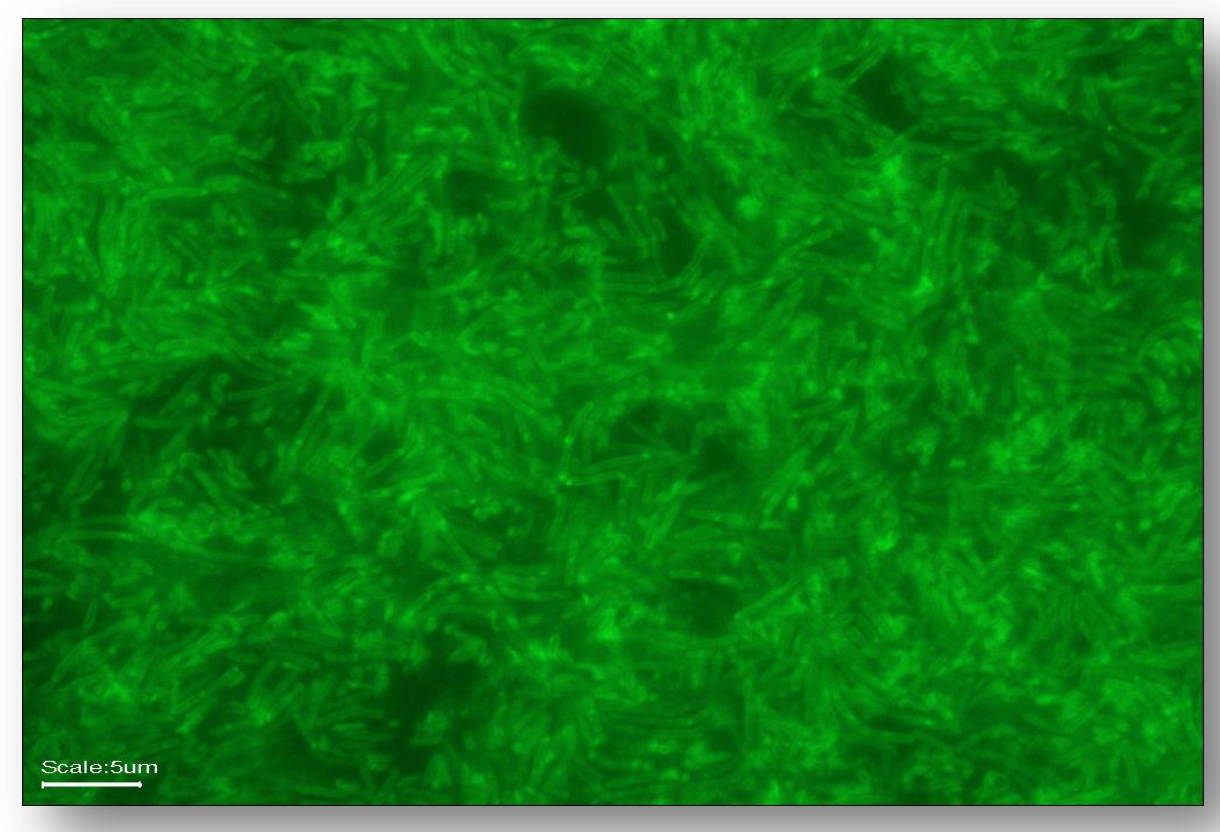

Figure 47. Visualization of $P$. stutzeri Population 1 T15 on the surface of glass coverslips.

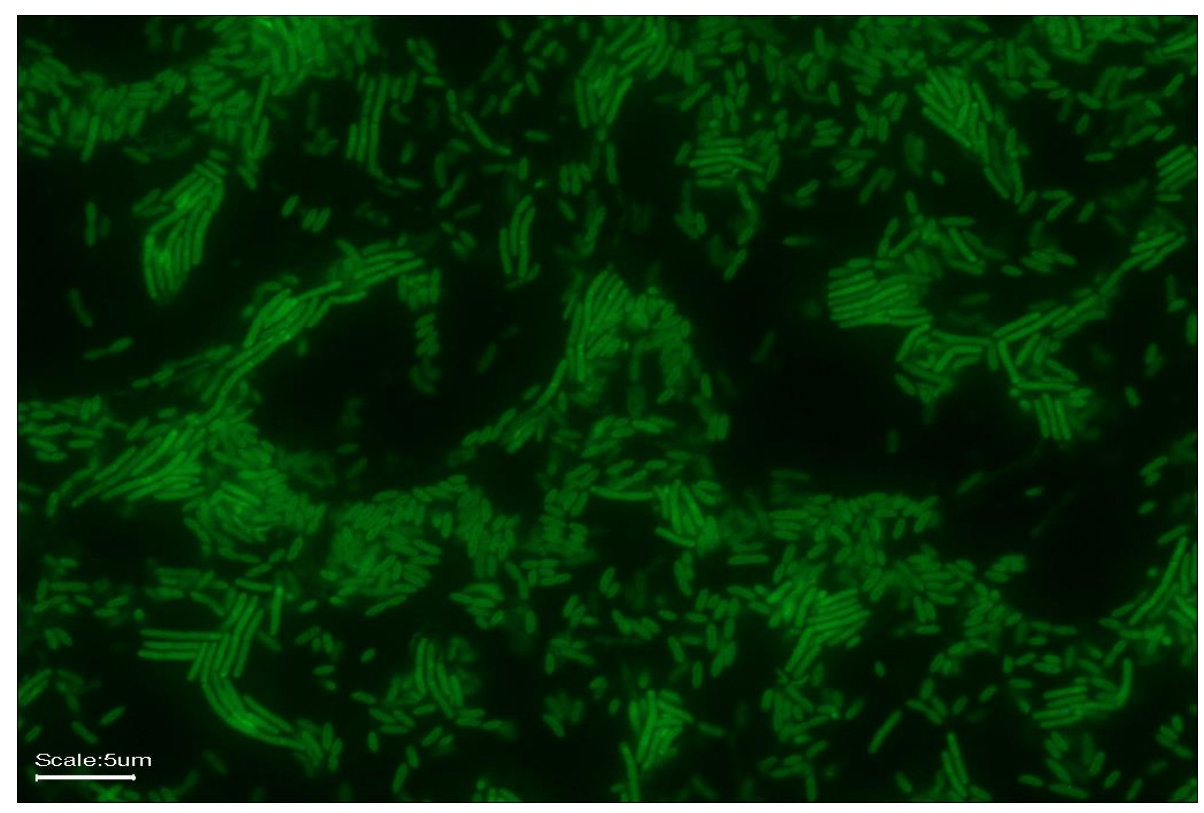

Figure 48. Visualization of $P$. stutzeri Population 2 T15 on the surface of glass coverslips. 


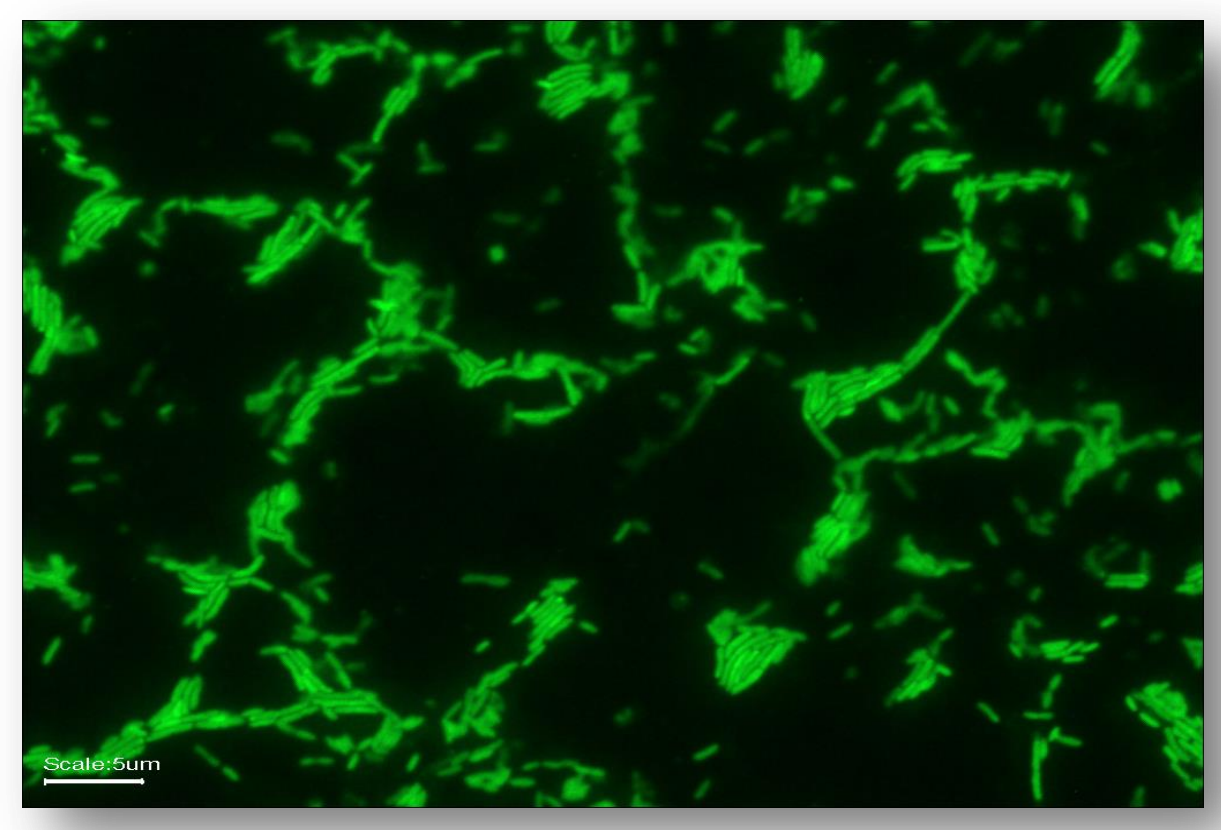

Figure 49. Visualization of $\boldsymbol{P}$. stutzeri Population 3 T15 on the surface of glass coverslips. 


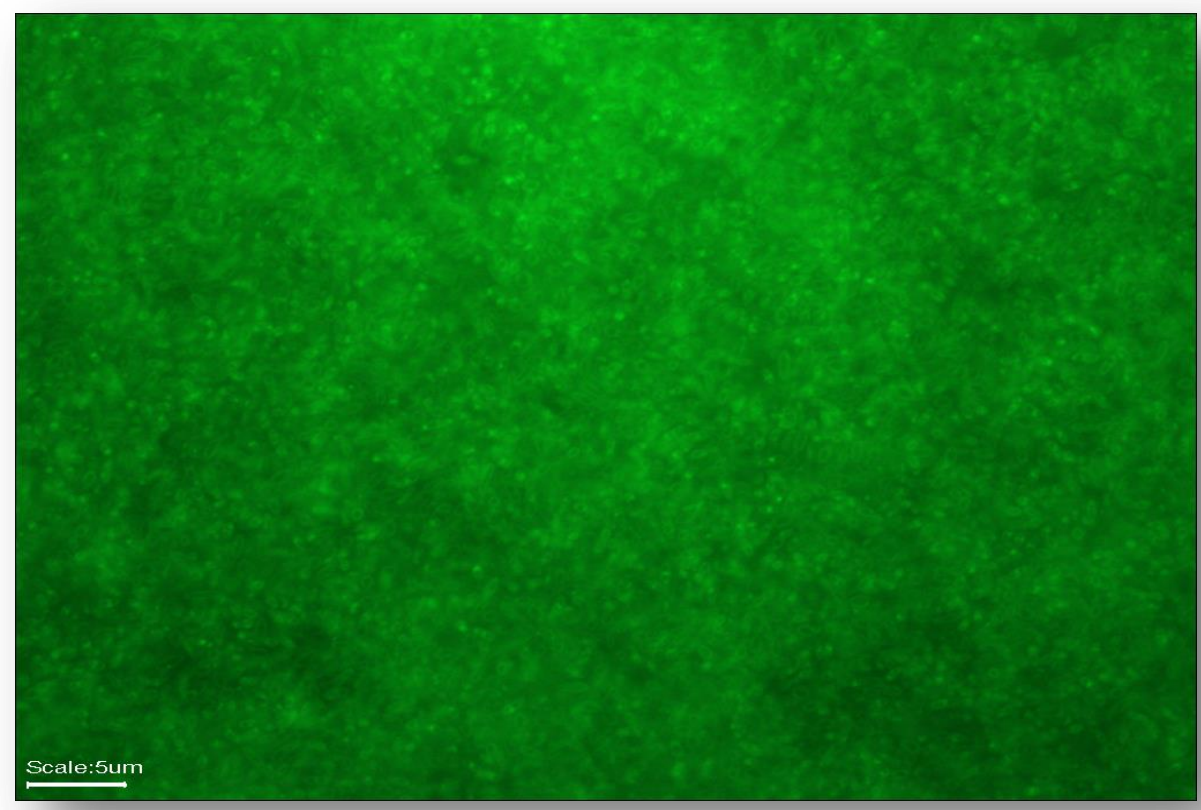

Figure 50. Visualization of Arthrobacter spp. Population 1 T28 on the surface of glass coverslips.

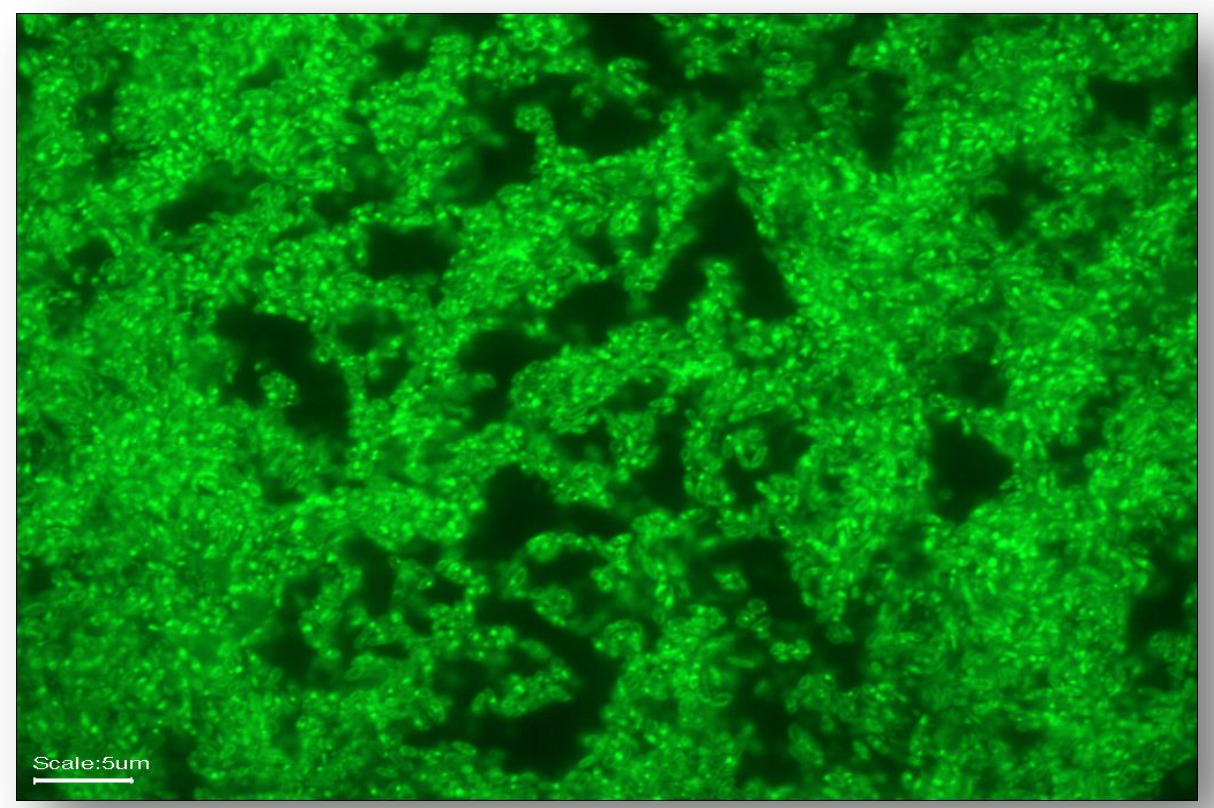

Figure 51. Visualization of Arthrobacter spp. Population 2 T28 on the surface of glass coverslips. 


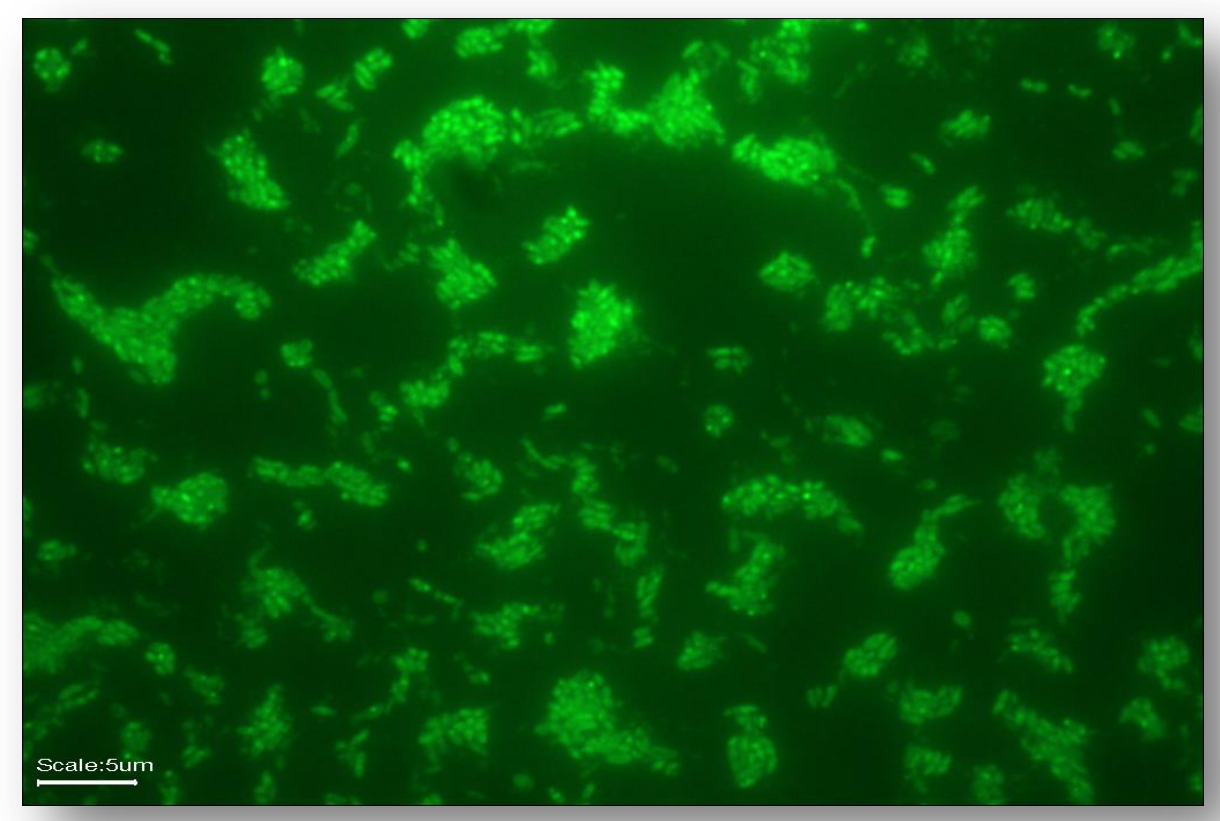

Figure 52. Visualization of Arthrobacter spp. Population 3 T28 on the surface of glass coverslips. 


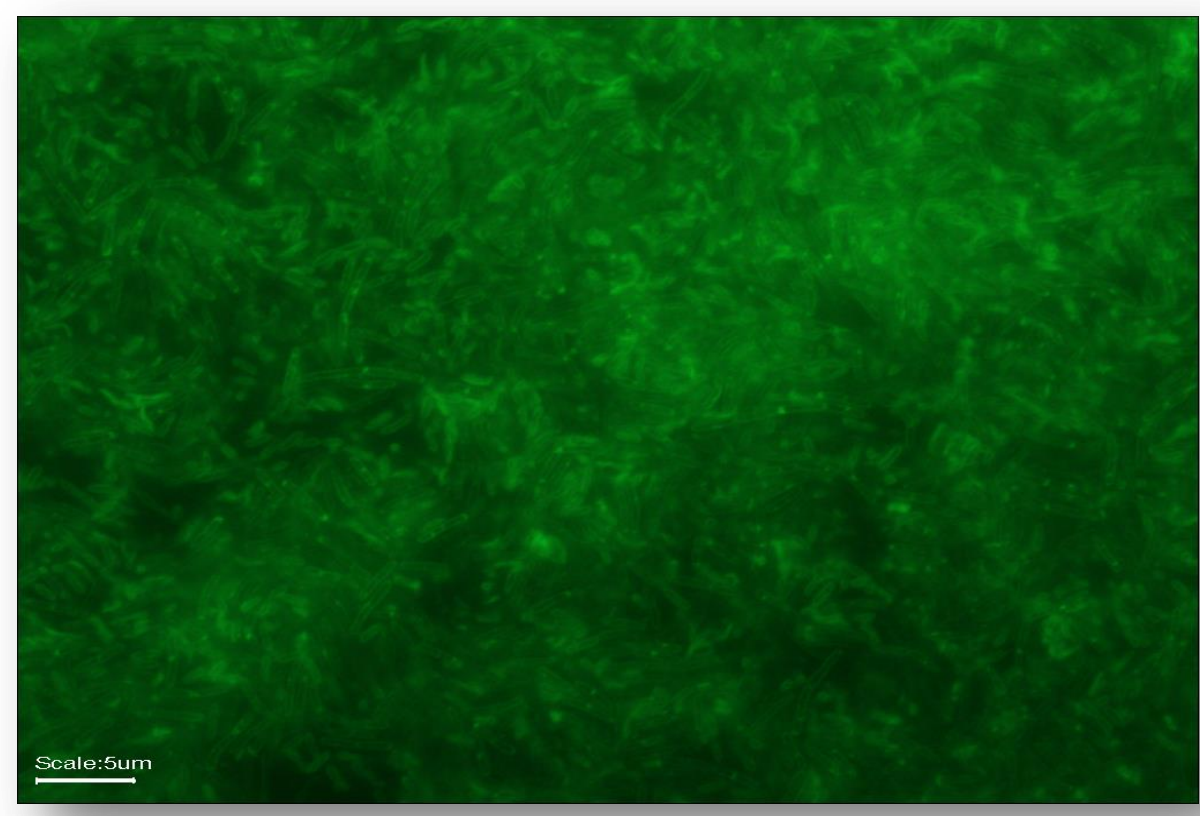

Figure 53. Visualization of $P$. stutzeri Population 1 T28 on the surface of glass coverslips.

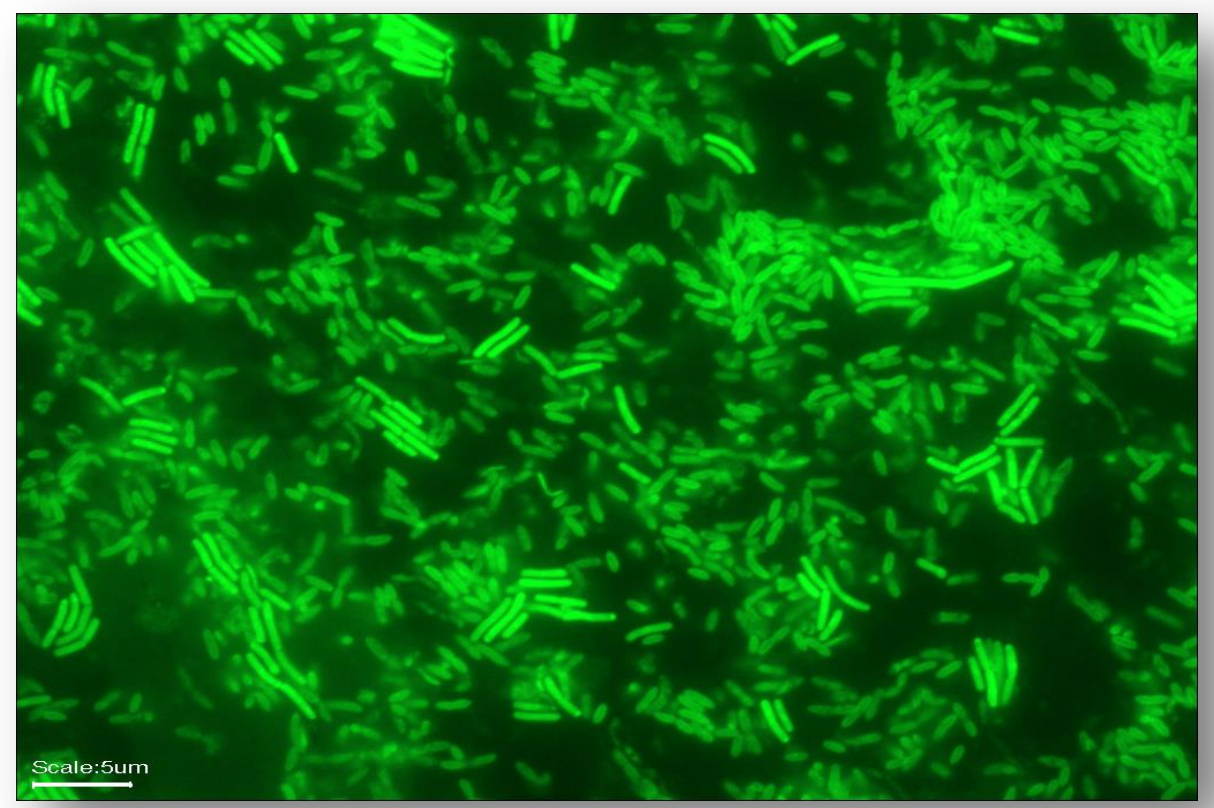

Figure 54. Visualization of $P$. stutzeri Population 2 T28 on the surface of glass coverslips. 


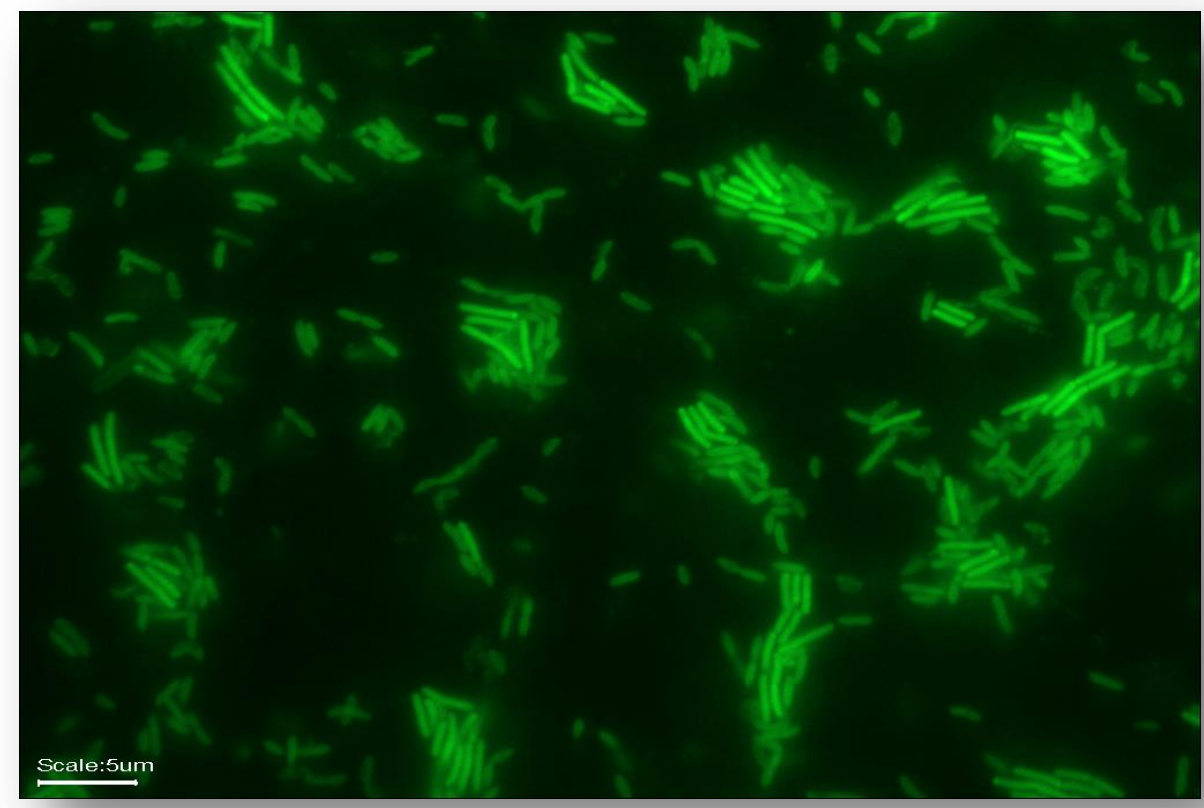

Figure 55. Visualization of $\boldsymbol{P}$. stutzeri Population 3 T28 on the surface of glass coverslips. 


\section{APPENDIX C}

This section presents the raw data obtained by using SAS Enterprise (9.4) for statistical analysis used to generate graphs shown in Figure 5,6,7,8, and 9.

The One-way Analysis of Variance (ANOVA) was used to assess the effects of treatment on morphology of cells (cell volume and length/width) at Day 31, expressed as percentages of morphological.

\section{Raw data for Figure 5:}

\section{Viable Cell Counts}

$\nabla$ General

Effects coding used for categorical variables in model.

The categorical values encountered during processing are

\begin{tabular}{|l|l|}
\hline Variables & \multicolumn{1}{|c|}{ Levels } \\
\hline TREATMENT\$ (3 levels) & $\begin{array}{l}\text { Arthrobacter } \\
\text { sprthrobacter } / \text { Arthrobacter }\end{array}$ \\
& sp. $1.40 \mathrm{E}+$ sp. $(2.60 \mathrm{E}+$ sp. $(3.85 \mathrm{E}+$ \\
\hline
\end{tabular}

Dependent VariableVIABLE_CELLS

\begin{tabular}{|l|l|}
\hline N & 32 \\
\hline Multiple R & 0.89739 \\
\hline Squared Multiple R & 0.80531 \\
\hline
\end{tabular}

\begin{tabular}{|c|c|c|}
\hline \\
\hline \multicolumn{3}{|c|}{\begin{tabular}{|l|l|l|} 
Factor & Level & VIABLE
\end{tabular}} \\
\hline CONSTANT & & 12.19934 \\
\hline TIME & & -1.42597 \\
\hline TREATMENT\$ & $\begin{array}{l}\text { Arthrobacter } \\
\text { sp. }(1.40 \mathrm{E}+\end{array}$ & 2.51241 \\
\hline TREATMENT\$ & $\begin{array}{l}\text { Arthrobacter } \\
\text { sp. }(2.60 \mathrm{E}+\end{array}$ & -1.34191 \\
\hline TREATMENT $\${ }^{*}$ & $\begin{array}{l}\text { Arthrobacter } \\
\text { sp. }(1.40 \mathrm{E}+\end{array}$ & 1.08091 \\
\hline TREATMENT $\${ }^{*}$ & $\begin{array}{l}\text { Arthrobacter } \\
\text { sp. }(2.60 \mathrm{E}+\end{array}$ & \\
\hline
\end{tabular}




\begin{tabular}{|l|l|l|l|l|l|}
\hline $\begin{array}{l}\text { Analysis of Variance } \\
\text { Source }\end{array}$ & Type III SS & df & Mean Squares & F-Ratio & p-Value \\
\hline TIME & 387.81094 & 1 & 387.81094 & 55.22428 & 0.00000 \\
\hline TREATMENT\$ & 59.25807 & 2 & 29.62904 & 4.21917 & 0.02589 \\
\hline TREATMENT\$*TIME & 213.96903 & 2 & 106.98451 & 15.23460 & 0.00004 \\
\hline Error & 182.58426 & 26 & 7.02247 & & \\
\hline
\end{tabular}

\section{Least Squares Means}

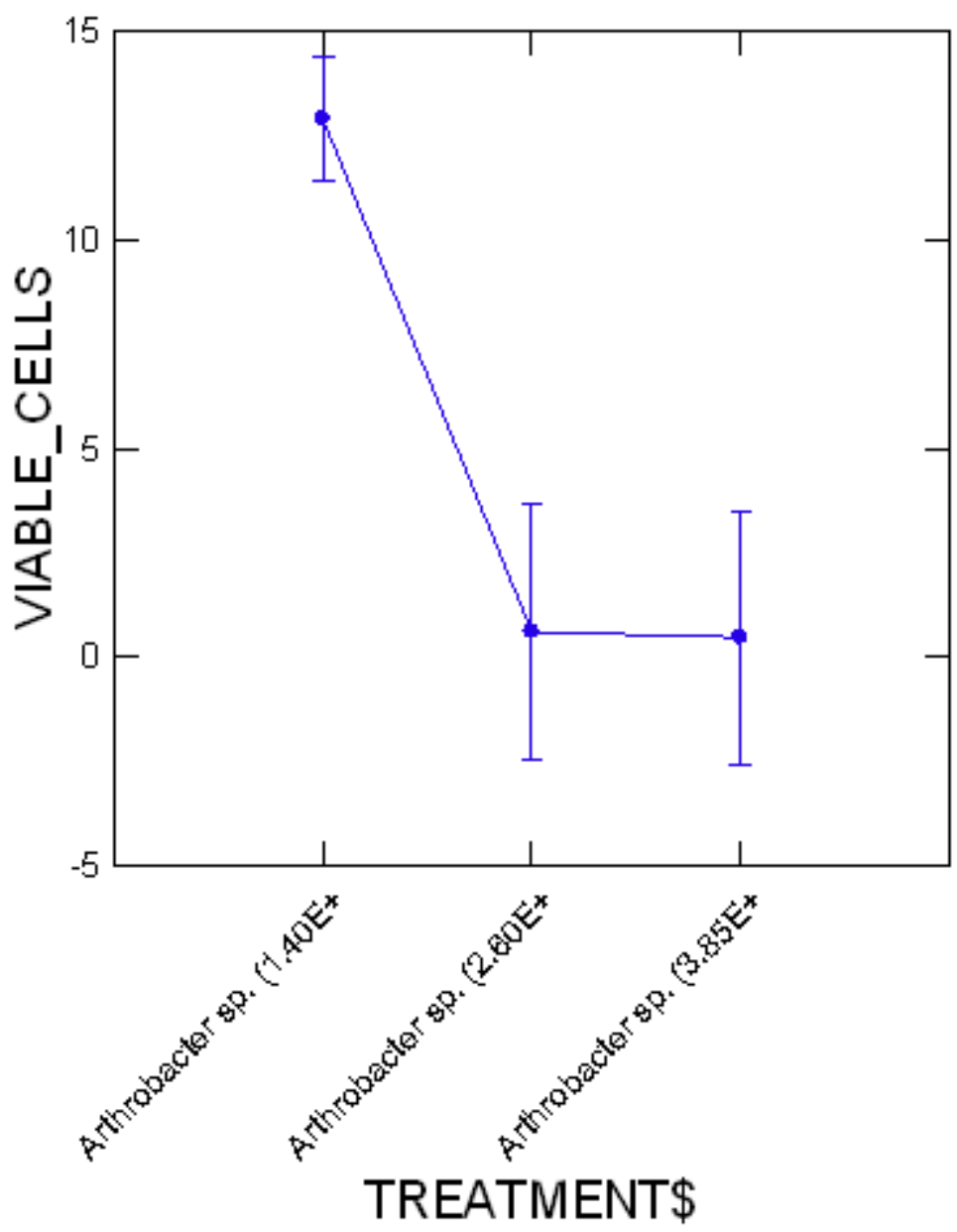

Durbin-Watson D-Statistic 1.67472

First Order Autocorrelation 0.15271

Information Criteria

\begin{tabular}{|l|l|}
\hline AIC & 160.53929 \\
\hline AIC (Corrected) & 165.20596 \\
\hline
\end{tabular} 


\begin{tabular}{|l|l|}
\hline \multicolumn{2}{|l|}{ Information Criteria } \\
AIC & 160.53929 \\
\hline Schwarz's BIC & 170.79944 \\
\hline
\end{tabular}

\section{Total Cell Counts}

$\nabla$ General

Effects coding used for categorical variables in model.

The categorical values encountered during processing are

\begin{tabular}{|c|c|}
\hline Variables & Levels \\
\hline TREATMENT\$ (3 levels) & $\begin{array}{l}\text { Arthrobacter|Arthrobacter Arthrobacter } \\
\text { sp. }(1.40 \mathrm{E}+\text { sp. }(2.60 \mathrm{E}+\text { sp. }(3.85 \mathrm{E}+\end{array}$ \\
\hline & $\begin{array}{l}\text { Arthrobacter Arthrobacter Arthrobacter } \\
\text { sp. (1.40E+ sp. }(2.60 \mathrm{E}+\text { sp. }(3.85 \mathrm{E}+\end{array}$ \\
\hline
\end{tabular}

1 case(s) are deleted due to missing data.

Dependent VariableTTOTAL_CELLS

\begin{tabular}{|l|l|}
\hline $\mathrm{N}$ & 38 \\
\hline Multiple R & 0.91223 \\
\hline Squared Multiple R & 0.83217 \\
\hline
\end{tabular}

\begin{tabular}{|c|c|c|}
\hline \multicolumn{3}{|c|}{ Estimates of Effects $B=\left(X^{\prime} X\right)^{-1} X^{\prime} Y$} \\
\hline Factor & Level & TOTAL_CELLS| \\
\hline CONSTANT & & 13.00006 \\
\hline TIME2 & & -0.04778 \\
\hline TREATMENT2\$ & $\begin{array}{l}\text { Arthrobacter } \\
\text { sp. }(1.40 \mathrm{E}+\end{array}$ & r3.04675 \\
\hline TREATMENT2\$ & $\begin{array}{l}\text { Arthrobacter } \\
\text { sp. }\left(2.60 \mathrm{E}_{+}\right.\end{array}$ & $r 0.21167$ \\
\hline TREATMENT2\$*TIME2 & $\begin{array}{l}\text { Arthrobacter } \\
\text { sp. }(1.40 \mathrm{E}+\end{array}$ & $r 0.02876$ \\
\hline TREATMENT2\$*TIME2 & $\begin{array}{l}\text { Arthrobacter } \\
\text { sp. }(2.60 \mathrm{E}+\end{array}$ & $r-0.00984$ \\
\hline
\end{tabular}

\begin{tabular}{|l|l|l|l|l|l|}
\hline $\begin{array}{l}\text { Analysis of Variance } \\
\text { Source }\end{array}$ & \multicolumn{1}{l}{ Type III SS } & df & Mean Squares & F-Ratio & p-Value \\
\hline TIME2 & 10.12658 & 1 & 10.12658 & 5.46743 & 0.02579 \\
\hline TREATMENT2\$ & 149.67535 & 2 & 74.83768 & 40.40553 & 0.00000 \\
\hline TREATMENT2\$ ${ }^{*}$ TIME2 & 1.88140 & 2 & 0.94070 & 0.50789 & 0.60653 \\
\hline Error & 59.26926 & 32 & 1.85216 & & \\
\hline
\end{tabular}




\section{Cell Volume}

\section{$\nabla$ Analysis}

Effects coding used for categorical variables in model.

The categorical values encountered during processing are

\begin{tabular}{|l|l|}
\hline Variables & \multicolumn{2}{|c|}{ Levels } \\
\hline TREAT (3 levels) & 5.000006 .000007 .00000 \\
\hline
\end{tabular}

\begin{tabular}{|l|l|}
\hline Dependent Variable & VOLUME \\
\hline $\mathrm{N}$ & 6 \\
\hline Multiple R & 0.95193 \\
\hline Squared Multiple R & 0.90617 \\
\hline
\end{tabular}

\begin{tabular}{|c|c|c|}
\hline \begin{tabular}{|l} 
Estimates 0 \\
${ }^{1} \mathrm{X}^{\prime} \mathrm{Y}$ \\
Factor
\end{tabular} & Effec & $S B=(X$ \\
\hline CONSTANT & & 96.50280 \\
\hline TREAT & 5 & 177.32875 \\
\hline TREAT & 6 & -52.99057 \\
\hline
\end{tabular}

Analysis of Variance

SourceType III SS df/Mean Squares|F-Ratio p-Value \begin{tabular}{|l|l|l|l|l|}
\hline TREAT $99,426.940072$ & $49,713.47003$ & 14.485730 .02874 \\
\hline
\end{tabular} \begin{tabular}{|l|l|l|l}
\hline Error & $10,295.680683$ & $3,431.89356$ \\
\hline
\end{tabular}

$\nabla$ Hypothesis

Post Hoc Test of VOLUME

Using least squares means.

Using model MSE of $3,431.89356$ with $3 \mathrm{df}$.

\begin{tabular}{|c|c|c|c|c|c|}
\hline \multicolumn{6}{|c|}{$\begin{array}{l}\text { Tukey's Honestly-Significant-Difference Test } \\
\text { TREAT(i)|TREAT(j)|Difference|p-Value } 95 \% \text { Confidence Interval }\end{array}$} \\
\hline & & & & Lower & Upper \\
\hline 5 & 6 & 230.31932 & 0.05849 & $9-14.49997$ & 475.13861 \\
\hline 5 & 7 & 301.66693 & 0.02871 & 56.84765 & 546.48622 \\
\hline 6 & 7 & 71.34761 & 0.52155 & -173.47167 & 316.16690 \\
\hline
\end{tabular}


Least Squares Means

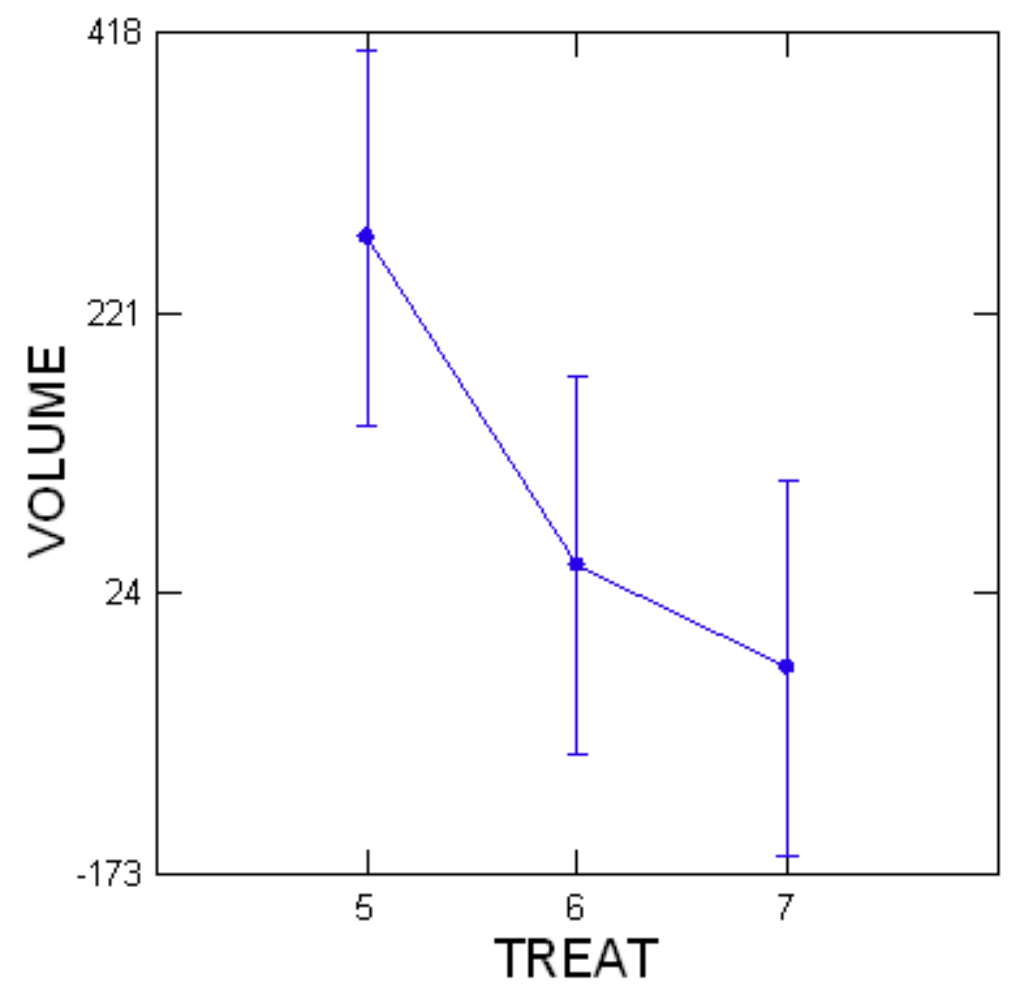




\section{Least Squares Means}

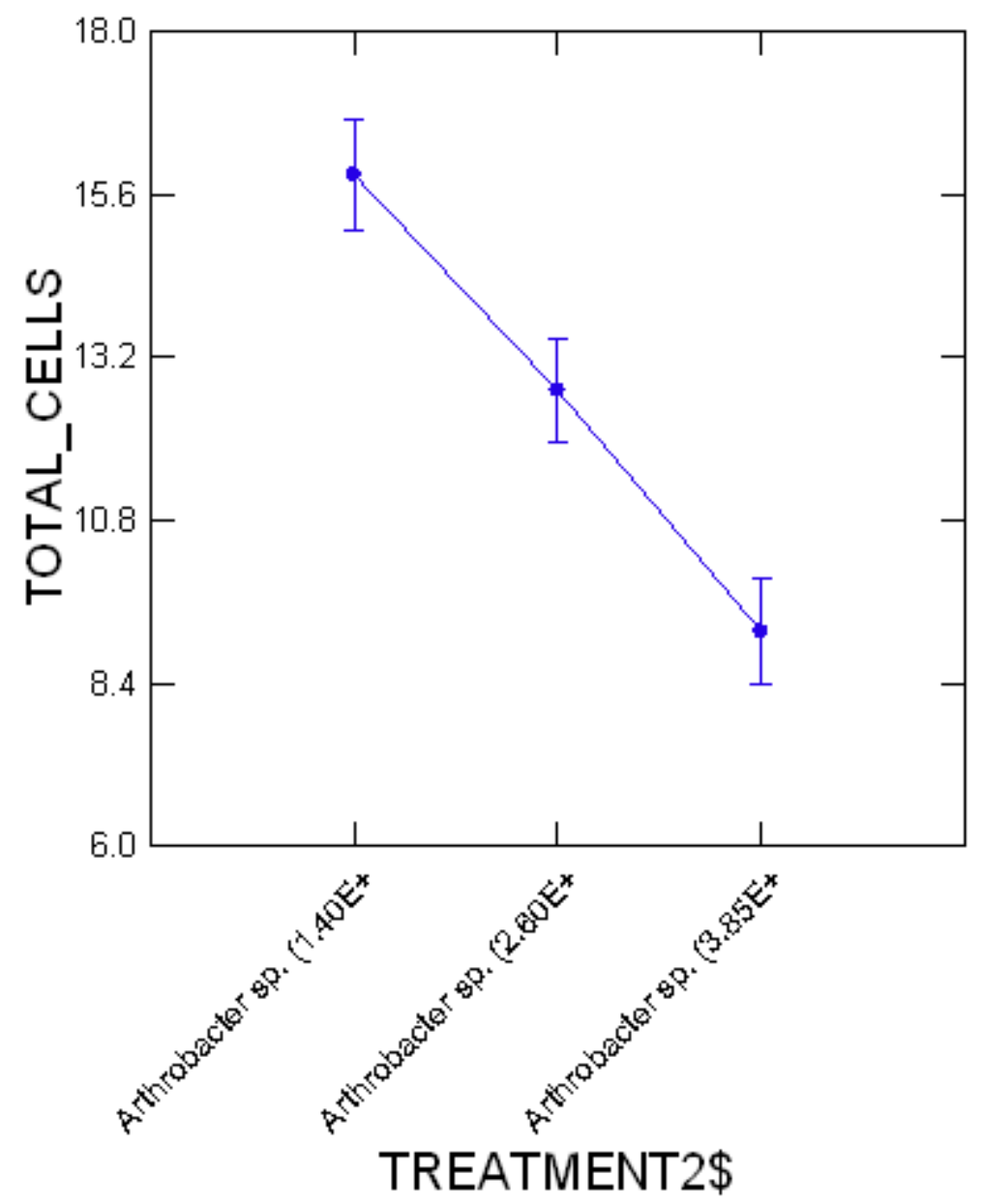

Durbin-Watson D-Statistic 1.55117

First Order Autocorrelation 0.21194

Information Criteria

AIC

138.73050

AIC (Corrected) 142.46384

\begin{tabular}{l|l|l|}
\hline Schwarz's BIC & 150.19361 \\
\hline
\end{tabular} 


\section{Cell Length/Cell Width}

$\boldsymbol{\nabla}$ Analysis

of

Variance

Effects coding used for categorical variables in model.

The categorical values encountered during processing are

\begin{tabular}{|c|c|}
\hline Variables & Levels \\
\hline TREAT (3 levels) & 5.000006 .000007 .00000 \\
\hline
\end{tabular}

\begin{tabular}{|l|l|}
\hline Dependent VariableLENGTH_WIDTH \\
\hline $\mathrm{N}$ & 6 \\
\hline Multiple R & 0.99438 \\
\hline Squared Multiple R & 0.98878 \\
\hline
\end{tabular}

\begin{tabular}{|c|c|}
\hline \multicolumn{2}{|c|}{ Estimates of Effects $B=\left(X^{\prime} X\right)^{-1} X^{\prime} Y$} \\
\hline Factor & |Level|LENGTH_WIDTH \\
\hline CONSTANT & 4.89082 \\
\hline TREAT & -3.36039 \\
\hline TREAT & -4.53931 \\
\hline
\end{tabular}

Analysis of Variance

Source/Type III SS df /Mean Squares/F-Ratio p-Value

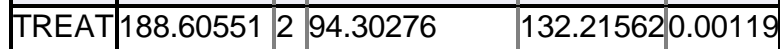

\begin{tabular}{|l|l|l|l|l|l|}
\hline Error & 2.13975 & 3 & 0.71325 & & \\
\hline
\end{tabular} 


\section{Least Squares Means}

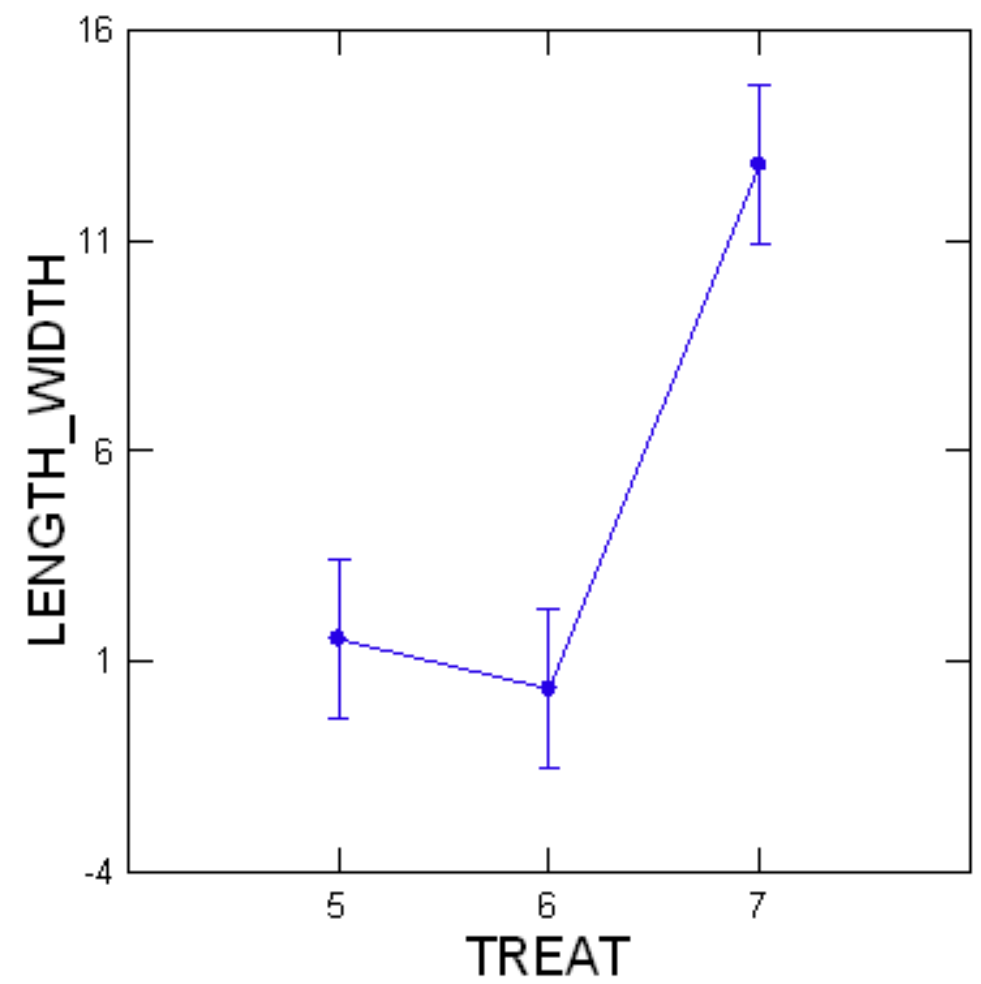

Durbin-Watson D-Statistic 2.33073

First Order Autocorrelation-0.27120

Information Criteria

\begin{tabular}{l|l|} 
AIC & 18.84084 \\
\hline AIC & (Corrected) $58.84084 \mid$
\end{tabular}

AIC (Corrected) 58.84084

\begin{tabular}{l|l|}
\hline Schwarz's BIC & 18.00788 \\
\hline
\end{tabular} 


\section{Confidence Interval and Prediction Interval}

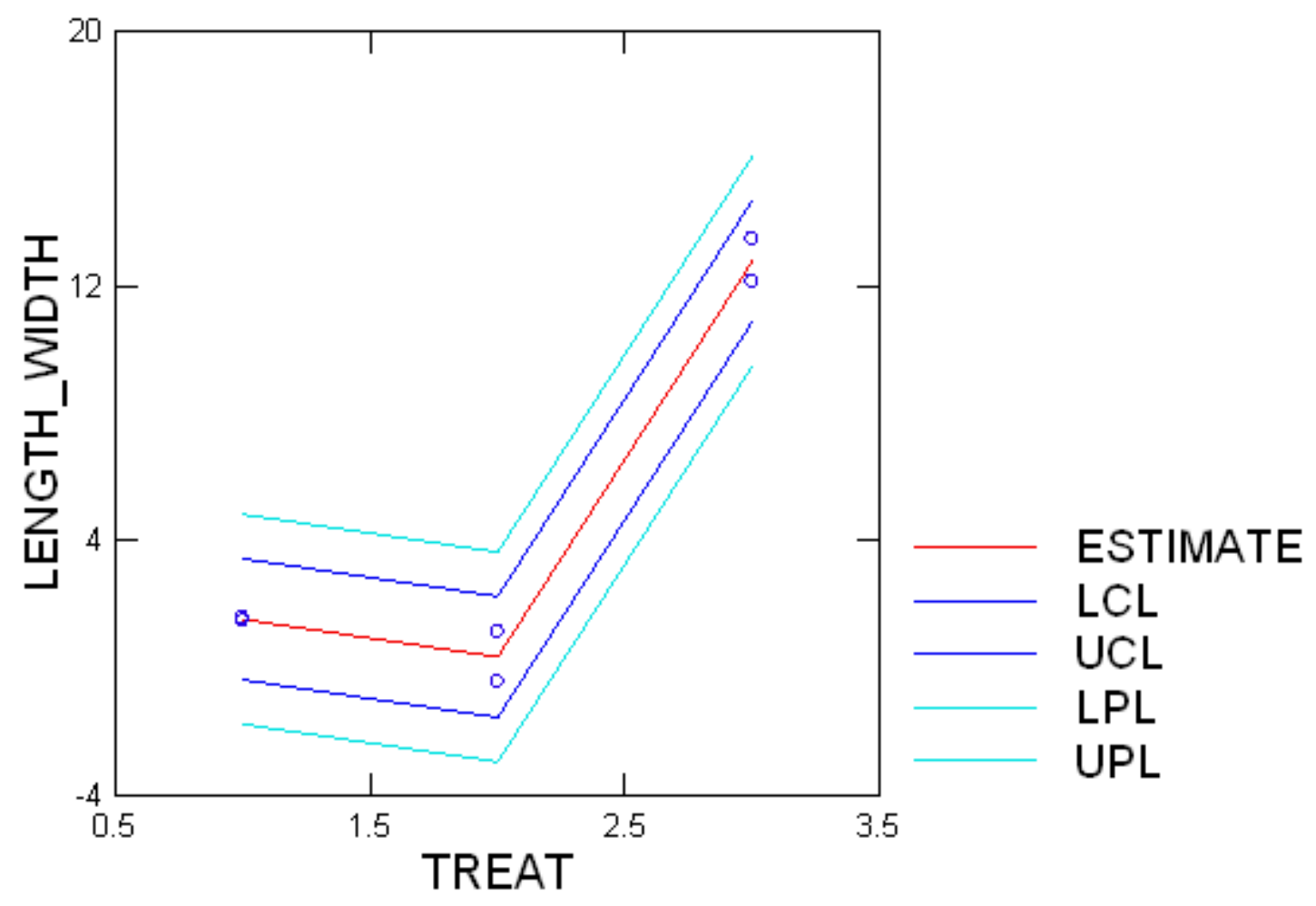




\section{Plot of Residuals vs. Predicted Values}

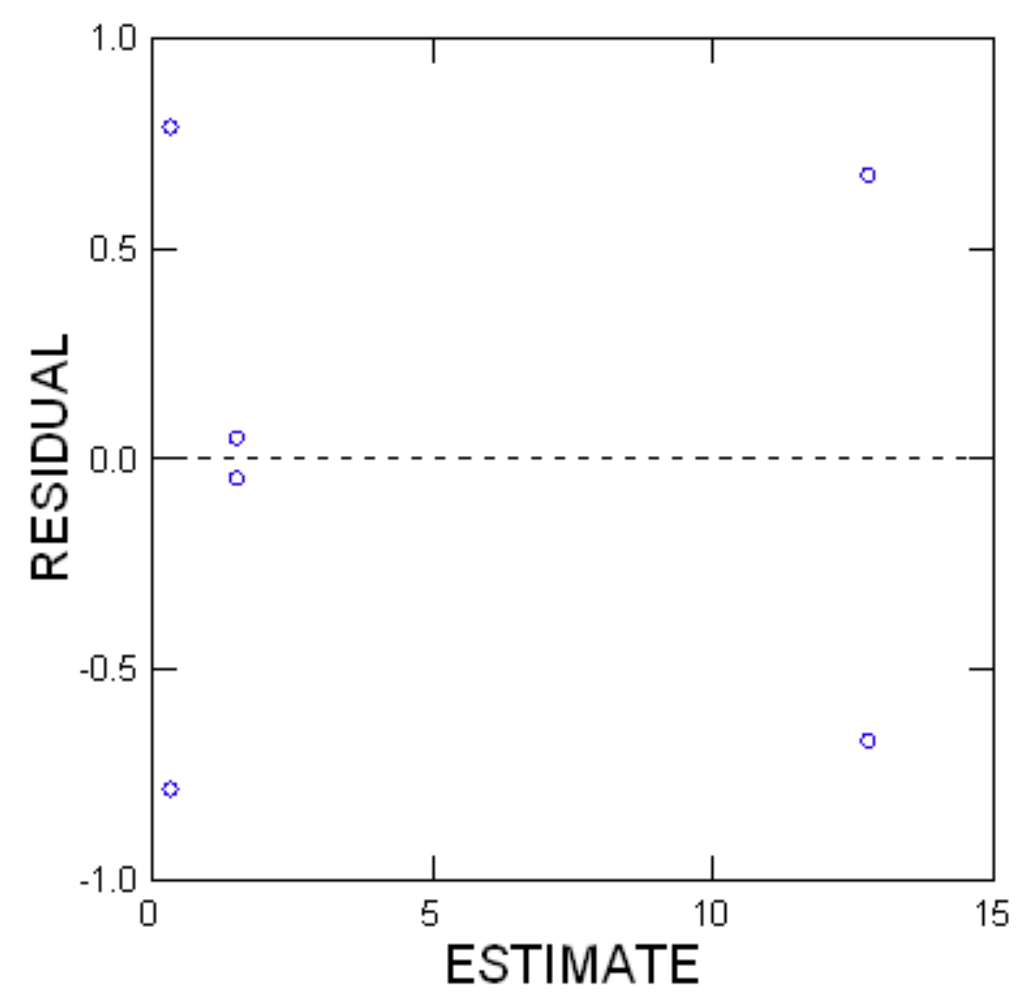

$\boldsymbol{\nabla}$ Hypothesis

Tests

Post Hoc Test of LENGTH_WIDTH

Using least squares means.

Using model MSE of 0.71325 with $3 \mathrm{df}$.

Tukey's Honestly-Significant-Difference Test

TREAT(i)|TREAT(j)|Difference|p-Value $95 \%$ Confidence Interval|

\begin{tabular}{|c|c|c|c|c|}
\hline & & & Lower & Upper \\
\hline 5 & 6 & 1.17892 & $0.44587-2.35047$ & 4.70831 \\
\hline 5 & 7 & -11.26008 & $0.00189-14.78947$ & -7.73070 \\
\hline 6 & 7 & -12.43901 & $0.00141-15.96840$ & -8.90962 \\
\hline
\end{tabular}




\section{Raw data for Figure 6:}

\section{Viable Cell Counts}

\begin{tabular}{|l|l|l|l|l|l|}
\hline $\begin{array}{l}\text { Analysis of Variance } \\
\text { Source }\end{array}$ & \multicolumn{1}{l}{ Type III SS } & df & Mean Squares F-Ratio & p-Value \\
\hline TIME_VIABLE & 218.52008 & 1 & 218.52008 & 390.34602 & 0.00001 \\
\hline DENSITY_VIABLE\$ & 1.96014 & 2 & 0.98007 & 1.75072 & 0.26527 \\
\hline DENSITY_VIABLE\$TIME_VIABLE & 83.04777 & 2 & 41.52388 & 74.17480 & 0.00019 \\
\hline Error & 2.79906 & 5 & 0.55981 & & \\
\hline
\end{tabular}

Least Squares Means

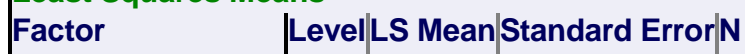

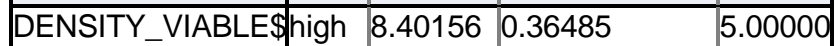

\begin{tabular}{|l|l|l|l|}
\hline DENSITY_VIABLE\$low & -2.92212 & 0.70359 & 3.00000 \\
\hline
\end{tabular}

\begin{tabular}{ll|l|l|l|}
\hline DENSITY_VIABLE\$ & mid & -3.28461 & 0.70359 & 3.00000 \\
\hline
\end{tabular}

* Means are computed after adjusting covariate effect.

\section{Least Squares Means}

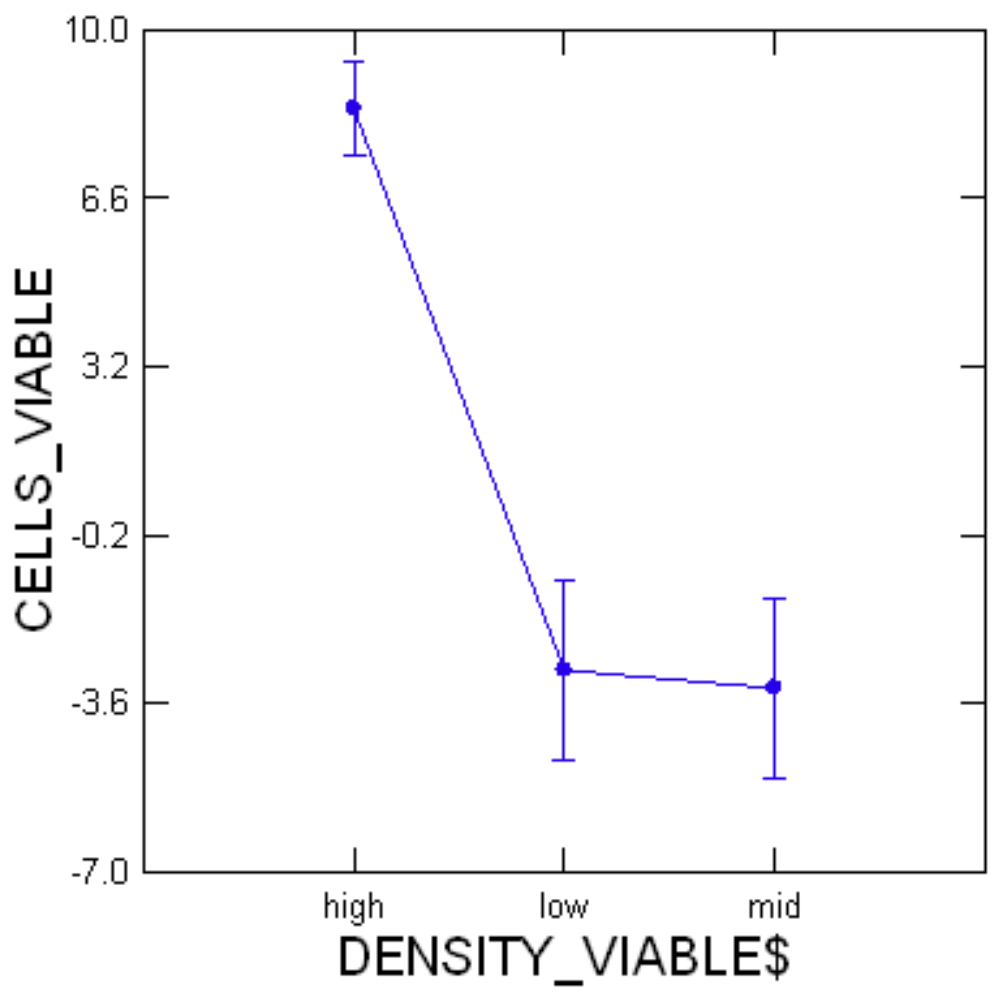




\section{Total Cells}

\begin{tabular}{|l|l|l|l|l|l|}
\hline $\begin{array}{l}\text { Analysis of Variance } \\
\text { Source }\end{array}$ & \multicolumn{1}{l}{ Type III SS } & df & Mean Squares & F-Ratio & p-Value \\
\hline TIME_WHOLE & 12.25999 & 1 & 12.25999 & 17.75521 & 0.00027 \\
\hline DENSITY_WHOLE\$ & 45.37685 & 2 & 22.68842 & 32.85791 & 0.00000 \\
\hline DENSITY_WHOLE\$*TIME_WHOLE & 1.80989 & 2 & 0.90494 & 1.31056 & 0.28690 \\
\hline Error & 17.95303 & 26 & 0.69050 & & \\
\hline
\end{tabular}

Least Squares Means

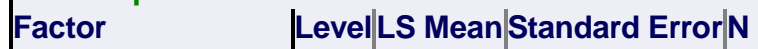

\begin{tabular}{|l|l|l|}
\hline DENSITY_WHOLE\$ & 10.00000 \\
\hline
\end{tabular}

\begin{tabular}{lll|}
\hline DENSITY_WHOLE\$low & 12.617370 .25055 & 11.00000 \\
\hline
\end{tabular}

\begin{tabular}{|c|c|}
\hline DENSITY_WHOLE\$mid & 13.459410 .25055 \\
\hline
\end{tabular}

* Means are computed after adjusting covariate effect.

\section{Least Squares Means}

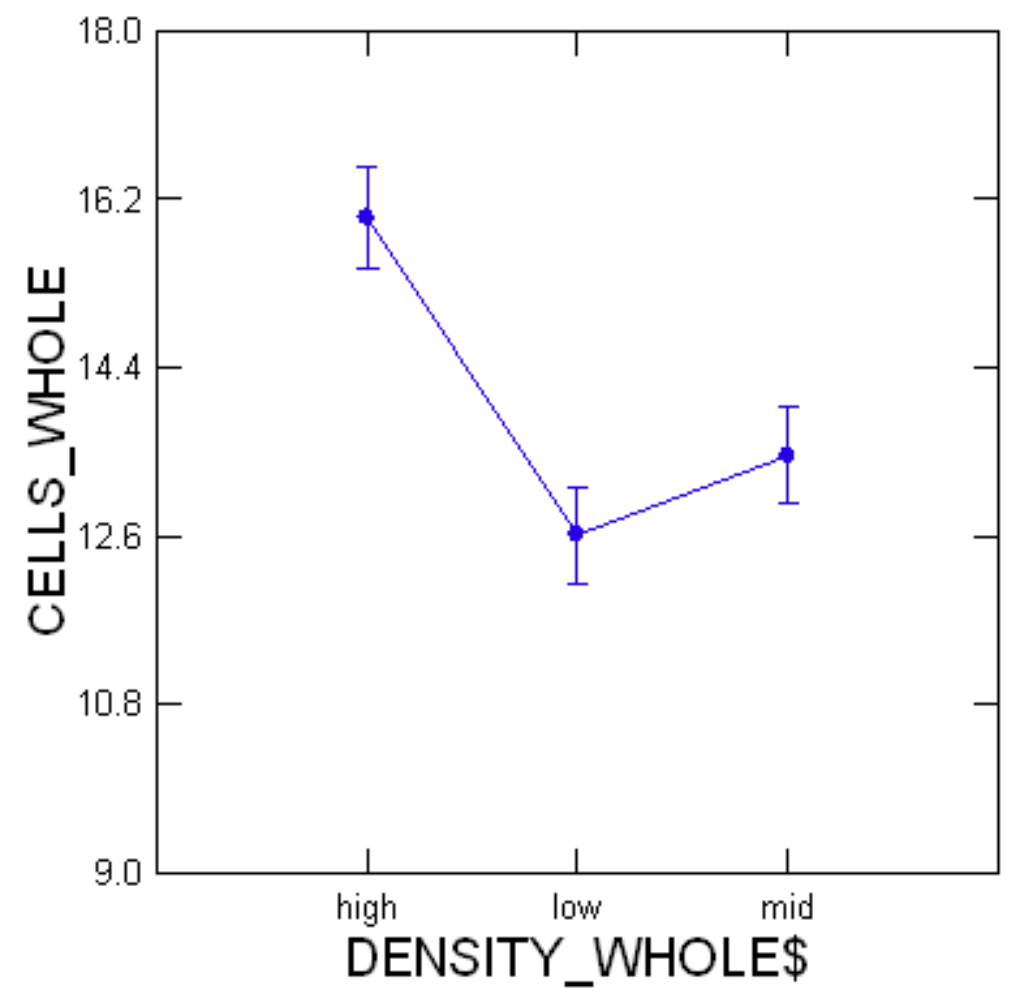




\section{Cell Volume}

\begin{tabular}{|c|c|c|c|}
\hline \multicolumn{4}{|c|}{ Analysis of Variance } \\
\hline Source & |Type III SS df|Mean Squares & F-Ratio & p-Value \\
\hline DENSITY $\$$ & \begin{tabular}{|l|l|}
$48,083.955672$ & $24,041.97783$ \\
\end{tabular} & 16.7027 & 10.02366 \\
\hline Error & \begin{tabular}{|l|l|l|}
$4,318.21636$ & 3 & $1,439.40545$ \\
\end{tabular} & & \\
\hline
\end{tabular}

\begin{tabular}{|c|c|c|c|c|}
\hline \multicolumn{5}{|c|}{$\begin{array}{l}\text { Tukey's Honestly-Significant-Difference Test } \\
\text { DENSITY\$(i)DENSITY\$(j)|Difference } p \text {-Value } 95 \% \text { Confidence Interval }\end{array}$} \\
\hline & & & Lower & Upper \\
\hline high & low & -213.04215 & $0.02266-371.59363$ & -54.49067 \\
\hline high & mid & -61.54611 & $0.36365-220.09759$ & 97.00537 \\
\hline low & mid & 151.49604 & $0.05621-7.05543$ & 310.04752 \\
\hline
\end{tabular}

\section{Cell Length/Volume}

\begin{tabular}{|c|c|c|}
\hline \multicolumn{3}{|c|}{ Analysis of Variance } \\
\hline & |Type III SS/df|Mean Squares & F-Ratio p-Value \\
\hline$\overline{\text { DENSITY }}$ & \begin{tabular}{|l|l|l|}
77.59780 & 2 & 38.79890 \\
\end{tabular} & 7.639950 .06648 \\
\hline Error & $15.23527 \quad 35.07842$ & \\
\hline
\end{tabular}

\section{Raw data for Figure 7:}

Viable cells: ANCOVA

\begin{tabular}{|c|c|c|c|c|}
\hline $\begin{array}{l}\text { Analysis of Variance } \\
\text { Source }\end{array}$ & |Type III SS o & df |Mean Squares & sF-Ratio & p-Value \\
\hline TREAT VAI\$ & 0.17886 & \begin{tabular}{l|l}
1 & 0.17886
\end{tabular} & 0.17960 & 0.67398 \\
\hline TIME_VIA & 603.820351 & 1603.82035 & 606.34226 & 60.00000 \\
\hline TREAT_VAI $\$$ *TIME_VI & A|47.44938 1 & 147.44938 & 47.64756 & 0.00000 \\
\hline Error & $39.83363 \quad 4$ & 400.99584 & & \\
\hline
\end{tabular}

\begin{tabular}{|c|c|c|c|}
\hline \multicolumn{4}{|c|}{ Least Squares Means } \\
\hline Factor & |Level & LS MeanStandar & $\mathbf{r} \mathbf{N}$ \\
\hline TREAT_VAI\$ & contro & 11.230430 .21276 & 22.00000 \\
\hline TREAT_VAI\$ & killed & 13.219870 .21276 & 22.00000 \\
\hline
\end{tabular}

\section{Total Cells}

\begin{tabular}{|l|l|l|l|l|l|}
\hline $\begin{array}{l}\text { Analysis of Variance } \\
\text { Source }\end{array}$ & Type III SS & df & Mean Squares & F-Ratio & p-Value \\
\hline TREAT_TOTAL\$ & 10.99209 & 1 & 10.99209 & 31.073180 .00000 \\
\hline TIME_TOTAL & 1.91661 & 1 & 1.91661 & 5.41800 & 0.02602 \\
\hline TREAT_TOTAL\$*TIME_TOTAL & 0.20588 & 1 & 0.20588 & 0.58200 & 0.45079 \\
\hline Error & 12.02744 & 34 & 0.35375 & & \\
\hline
\end{tabular}

\section{Cell Volume (Note: ANOVA run using log10 transformed cell volumes)}




\begin{tabular}{|l|l|l|l|l|l|}
\hline $\begin{array}{l}\text { Analysis of Variance } \\
\text { Source }\end{array}$ & Type III SS & df & Mean Squares & F-Ratio & p-Value \\
\hline TREAT_VOL_WL $\$ 0.05876$ & 1 & 0.05876 & 23.63715 & 0.00827 \\
\hline Error & 0.00994 & 4 & 0.00249 & & \\
\hline
\end{tabular}

Cell length: width

\begin{tabular}{|l|l|l|l|l|l|}
\hline $\begin{array}{l}\text { Analysis of Variance } \\
\text { Source }\end{array}$ & Type III SS & df & Mean Squares & F-Ratio & p-Value \\
\hline TREAT_VOL_WL $\$ 69.66875$ & 1 & 69.66875 & 6.84474 & 0.07926 \\
\hline Error & 30.53532 & 3 & 10.17844 & & \\
\hline
\end{tabular}

\section{Raw data for Figure 8:}

\section{Viable cells: ANCOVA}

\begin{tabular}{|l|l|l|l|l|l|}
\hline $\begin{array}{l}\text { Analysis of Variance } \\
\text { Source }\end{array}$ & \multicolumn{1}{l}{ Type III SS } & df & Mean SquaresF-Ratio & p-Value \\
\hline TREAT_VAI\$ & 5.14748 & 1 & 5.14748 & 0.97068 & 0.33476 \\
\hline TIME_VIA & 261.68203 & 1 & 261.68203 & 49.34637 & 0.00000 \\
\hline TREAT_VAI\$*TIME_VIA & 32.08098 & 1 & 32.08098 & 6.04963 & 0.02185 \\
\hline Error & 121.96818 & 23 & 5.30296 & & \\
\hline
\end{tabular}

\section{Total Cells}

\begin{tabular}{|c|c|c|c|c|}
\hline $\begin{array}{l}\text { Analysis of Variance } \\
\text { Source }\end{array}$ & Type III S & df /Mean Squ & sF-Ratio & p-Value \\
\hline TREAT_TOTAL\$ & 2.69531 & \begin{tabular}{l|l}
1 & 2.69531
\end{tabular} & 1.46394 & 0.23545 \\
\hline TIME_TOTAL & 31.16017 & 131.16017 & 16.92441 & 10.00027 \\
\hline TREAT_TOTAL $\$$ *TIME_TOTAL & 40.25136 & 10.25136 & 0.13653 & 0.71427 \\
\hline Error & 57.07526 & \begin{tabular}{l|l}
31 & 1.84114 \\
\end{tabular} & & \\
\hline
\end{tabular}

Cell Volume (note: ANOVA run using log10 transformed cell volumes) Analysis of Variance

\begin{tabular}{|l|l|l|l|l|l|}
\hline Source & Type III SS & df & Mean Squares & F-Ratio & p-Value \\
\hline TREAT_VOL_WL\$0.05099 & 1 & 0.05099 & 1.29812 & 0.33729 \\
\hline Error & 0.11784 & 3 & 0.03928 & & \\
\hline
\end{tabular}

Cell length: width

\begin{tabular}{|c|c|c|c|c|}
\hline \multicolumn{5}{|c|}{ Analysis of Variance } \\
\hline Source & Type III SSc & df|Mean Squares & F-Ratio & p-Value \\
\hline$\overline{\text { TREAT_VOL_WLS }}$ & $\$ 14.97726$ & $\begin{array}{ll}114.97726 \\
\end{array}$ & 1.47021 & 0.31209 \\
\hline Error & 30.56145 & 310.18715 & & \\
\hline
\end{tabular}


Raw data for Figure 9:

Viable cells: ANCOVA

\begin{tabular}{|l|l|l|l|l|l|}
\hline $\begin{array}{l}\text { Analysis of Variance } \\
\text { Source }\end{array}$ & \multicolumn{1}{l}{ Type III SS } & df & Mean Squares & F-Ratio & p-Value \\
\hline TREATMENT_VIABLE\$ & 3.39689 & 1 & 3.39689 & 3.10873 & 0.08591 \\
\hline TIME_VIABLE & 292.07932 & 1 & 292.07932 & 267.30188 & 0.00000 \\
\hline TREATMENT_VIABLE\$*TIME_VIABLE & 18.72857 & 1 & 18.72857 & 17.13981 & 0.00019 \\
\hline Error & 41.52239 & 38 & 1.09269 & & \\
\hline
\end{tabular}

Total Cells

\begin{tabular}{|l|l|l|l|l|l|}
\hline $\begin{array}{l}\text { Analysis of Variance } \\
\text { Source }\end{array}$ & \multicolumn{1}{l}{ Type III SS } & df & Mean Squares & F-Ratio & p-Value \\
\hline TREATMENT_TOTAL\$ & 12.19402 & 1 & 12.19402 & 32.16003 & 0.00000 \\
\hline TIME_TOTAL & 1.23707 & 1 & 1.23707 & 3.26260 & 0.07902 \\
\hline TREATMENT_TOTAL\$*TIME_TOTAL & 0.66608 & 1 & 0.66608 & 1.75669 & 0.19316 \\
\hline Error & 14.02918 & 37 & 0.37917 & & \\
\hline
\end{tabular}

Cell Volume (note: ANOVA run using log10 transformed cell volumes) Analysis of Variance Source $\quad$ Type III SS dff|Mean Squares|F-Ratio p-Value

\begin{tabular}{|l|l|l|l|}
\hline TREATMENT $\$ 0.14312$ & 1 & 0.14312 & 22.194900 .00923 \\
\hline
\end{tabular}

\begin{tabular}{|l|l|l|l|l|l|}
\hline Error & 0.02579 & 4 & 0.00645 & & \\
\hline
\end{tabular}

Cell length: width

Analysis of Variance

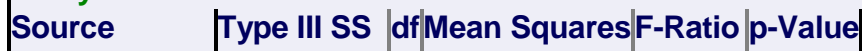

\begin{tabular}{|l|l|l|l|}
\hline TREATMENT $\$ 550.13519$ & 1 & 550.13519 & 1.514040 .28594 \\
\hline
\end{tabular}

\begin{tabular}{l|l}
\hline Error & $1,453.421434$ \\
\hline
\end{tabular} 


\section{APPENDIX D}

This section presents additional data for experiments involving isolated bacteria from Wyoming MX80 bentonite. Morphology descriptions are summarized in Table 7. The viability of isolated bentonite bacteria that did not survive throughout the experiment (period of 31 days) was further assess by using agar imprinting method to invert the coverslips on $3 \mathrm{~g} / \mathrm{L}$ TSA plates and counting the colonies 9 days after no viable counts were observed from the $10^{\circ}$ dilution. The $\mathrm{RH}$ of all samples was maintained at $42 \pm 3 \%$ for duration of the experiment, with exception of drying period (initial 3 hours at RH $60 \pm$ $5 \%$ ) prior to agar imprinting. Agar imprinting is utilized for qualitative assessment of survival and involves placing the coverslips face down (inoculated side was in contact with agar) on TSA plates $(3 \mathrm{~g} / \mathrm{L})$ to allow cells to transfer for 3 hours. Values at time 0 represent the initial viable cells in each population and $\mathrm{T}$ is measured in days. The coverslip is then removed and plates are incubated at room temperature for 3 days. In some instances, distinct colonies are formed that can be enumerated. Another coverslip was aseptically placed inside $5 \mathrm{~mL}$ of $3 \mathrm{~g} / \mathrm{L}$ TSB and incubated for 24 hours for further observation of growth. The results are summarized in Table 8. Three out of 6 isolates were spore-forming bacteria (Bacillus sp. 1047 and Brevibacterium spp.). Since the main focus of this study was

on survival of vegetative bacteria at solid-air interfaces, germination of named bacteria was not induced to further assess viability of the isolates under investigation. 
Table 7. Description of morpho-types and identity of isolated bacteria from MX-80 bentonite

\begin{tabular}{|l|l|l|l|l|l|}
\hline Identity & $\begin{array}{l}\text { Bentonite Isolate } \\
\text { Number }\end{array}$ & Colour of the Colonies & Form & Elevation & Margin \\
\hline Bacillus sp. $\mathbf{1 0 4 7}$ & 1 & Cream, large & Circular & Umbonate & Undolate \\
\hline Arthrobacter spp. & 2 & Redish pink, small & Circular & Convex & Entire \\
\hline Arthrobacter spp. & 3 & Yellowish cream, small & Circular & Convex & Entire \\
\hline Arthrobacter spp. & 4 & Cream & Circular & Convex & Entire \\
\hline Brevibacterium spp. & 5 & Pinkish cream & Circular & Umbonate & Undolate \\
\hline Pseudomonas stutzeri & 6 & Clear, cream center & Irregular & Umbonate & Curled \\
\hline Pseudomonas stutzeri & 7 & Cream & Punctiform & Convex & Enteric \\
\hline Brevibacterium spp. & 8 & Cream & Irregular & Umbonate & Lobate \\
\hline Arthrobacter spp. & 9 & Cream, medium & Circular & Convex & Entire \\
\hline Arthrobacter spp. & 10 & Cream, medium & Circular & Convex & Entire \\
\hline
\end{tabular}


Table 8. Assessing viability of isolated bacteria using agar imprinting

\begin{tabular}{|c|c|c|c|}
\hline Isolate Number & Bacteria Name & Qualitative Assessment in $\mathrm{mL}$ TSB $(3 \mathrm{~g} / \mathrm{L})$ & $\begin{array}{l}\text { Enumerated Bacteria Using } \\
\text { Agar Imprinting }(\mathrm{CFU} / \mathrm{mL})\end{array}$ \\
\hline BIS1 & Bacillus sp. 1047 & Growth & 6 \\
\hline BIS5 & Brevibacterium spp. & Growth & 0 \\
\hline BIS6 & Pseudomonas stutzeri & Growth & 0 \\
\hline BIS7 & Pseudomonas stutzeri & Growth & 0 \\
\hline BIS8 & Brevibacterium spp. & Growth & 13 \\
\hline BIS9 & Arthrobacter spp. & Growth & 0 \\
\hline
\end{tabular}

Agar imprinting was repeated for a follow up 170 days after inoculation. The RH of all samples was maintained at $42 \pm 3 \%$ for duration of the experiment, with exception of drying period (initial 3 hours at RH $60 \pm 5 \%$ ). Values at time 0 represent the initial viable cells in each population and $\mathrm{T}$ is measured in days. 
A $\quad$ B

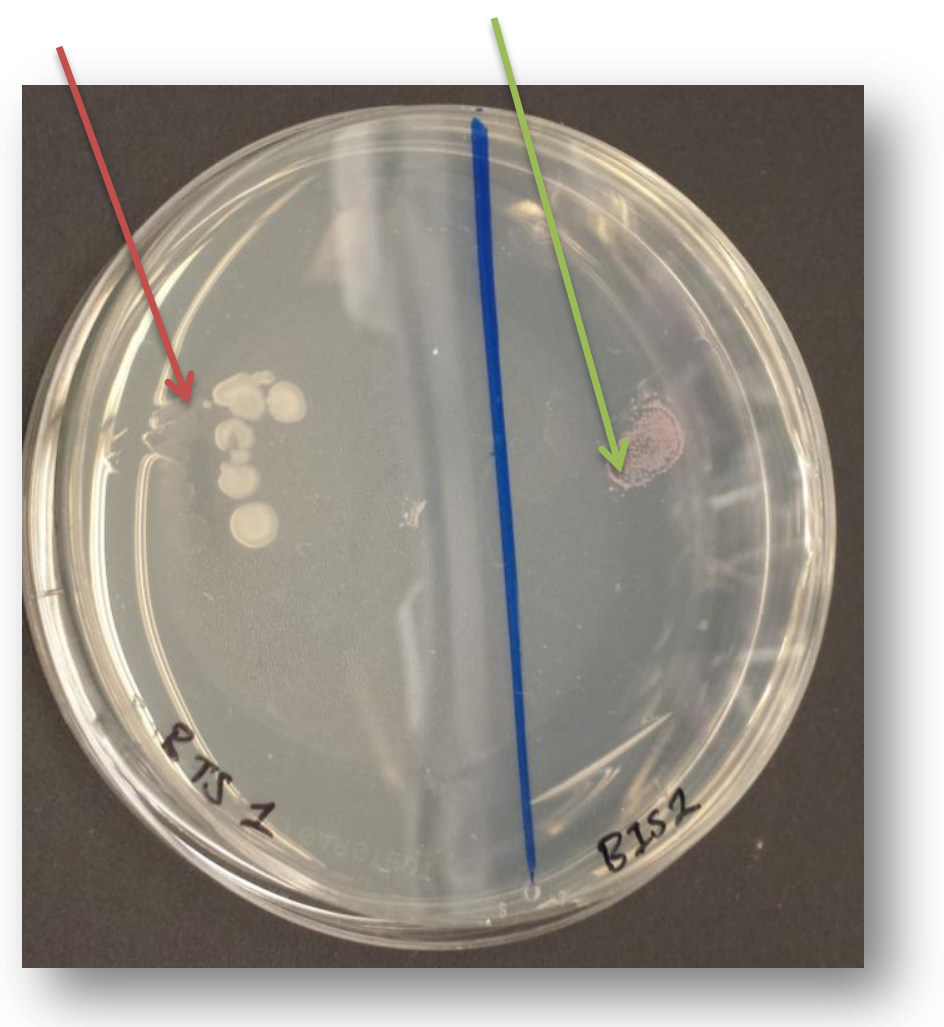

Figure 56. Qualitative results for agar imprinting. A) T170 inverted coverslip with dried Bacillus spp. 1047 cells (BIS 1).

No morphological changes were observed. B) T170 inverted coverslip with dried Arthrobacter spp. (BIS 2). No morphological changes were observed. Colony density was higher around the edges of the dried inoculum drop possibly because this region affects cell density and bioflocculation of bacteria cells prior to drying supported by surface tension in the outer region of the droplet. A net attraction toward the interior of liquid droplet causes this surface tension (there is no equal force exerted by adjacent liquid molecules to neutralize the force exerted by liquid molecules). 
C

$\mathrm{D}$

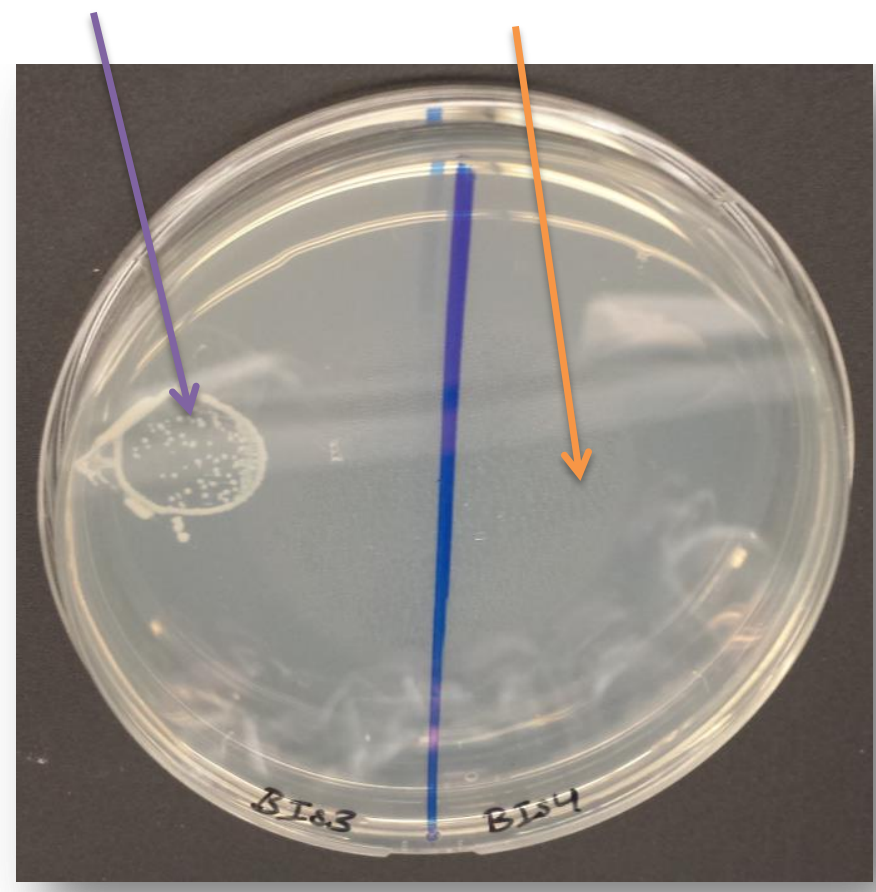

Figure 57. Qualitative results for agar imprinting. C) T170 inverted coverslip with dried Arthrobacter spp. cells (BIS 3).

Colony density was higher around the edges of the dried inoculum drop possibly because this region affects cell density and bioflocculation of bacteria cells prior to drying supported by surface tension in the outer region of the droplet. A net attraction toward the interior of liquid droplet causes this surface tension (there is no equal force exerted by adjacent liquid molecules to neutralize the force exerted by liquid molecules). D) T170 inverted coverslip with dried Arthrobacter spp. cells. (BIS 4). No colonies were observed. 


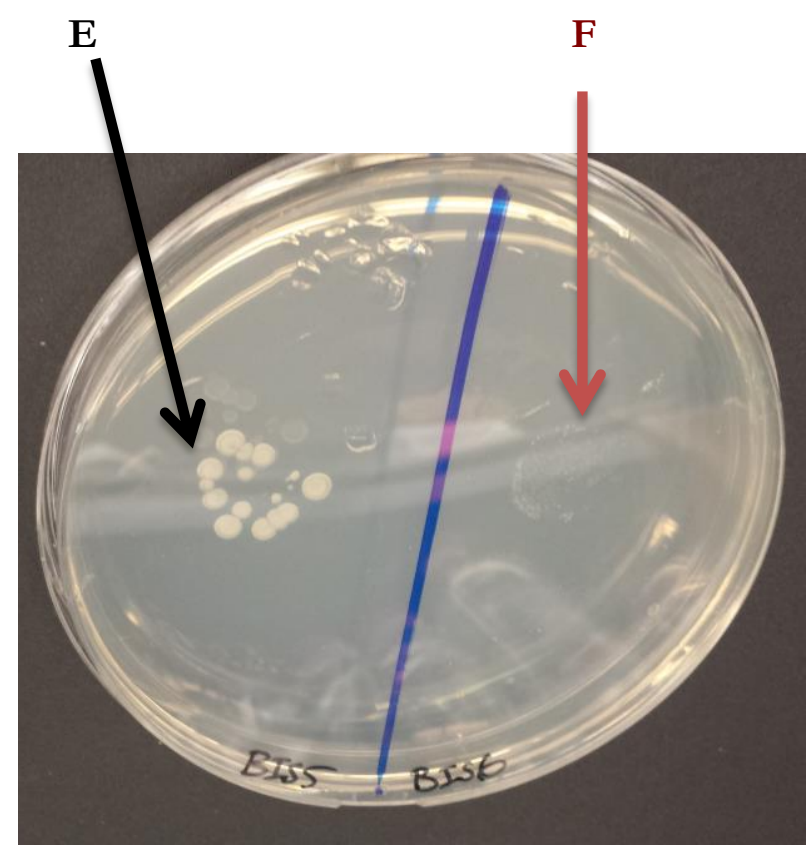

Figure 58. Qualitative results for agar imprinting. E) T170 inverted coverslip with dried Brevibacterium spp. (BIS 5).

F) T170 inverted coverslip with dried Pseudomonas stutzeri (BIS 6). For both populations colony density was higher around the edges of the dried inoculum drop possibly because this region affects cell density and bioflocculation of bacteria cells prior to drying supported by surface tension in the outer region of the droplet. A net attraction toward the interior of liquid droplet causes this surface tension (there is no equal force exerted by adjacent liquid molecules to neutralize the force exerted by liquid molecules). 


\section{APPENDIX E}

To explore methods for imaging dried cells at solid surfaces, $50 \mu \mathrm{L}$ of Arthrobacter spp. washed cultured with about $10^{1}$ to $10^{2}$ cells were stained prior to drying with $0.5 \mu \mathrm{L}$ fluorescent nucleic acid gel stain SYBR $^{\circledR}$ gold $(10,000 X$ Concentrate in DMSO; Thermo Fisher Scientific Inc., USA) followed by vortexing and incubation in the dark for 20 minutes. The cells were then dried using the method described in Section 4.2.5 either on a coverslip or onto a black polycarbonate filter (pore size $=0.2 \mu \mathrm{m}$, $25 \mathrm{~mm}$ diameter; Nuclepore, Whatman, VWR, Canada) placed on a microscope slide. The acquired epifluorescence images presented here demonstrated that this method allows for convenient visualization of dried cells overtime. 


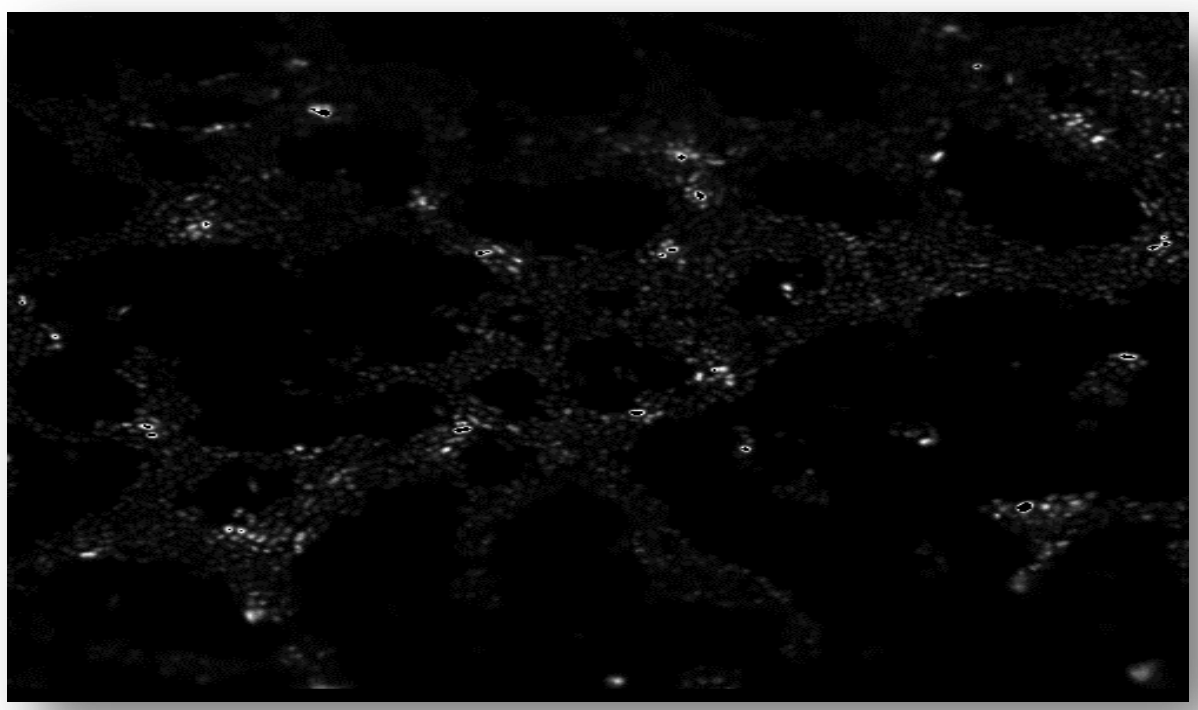

Figure 59. Replicate 1 for Arthrobacter spp. cells inoculated onto a black polycarbonate filter (viable culturable colonies were counted at about $10^{1} \mathrm{CFU} / \mathrm{mL}$ ).

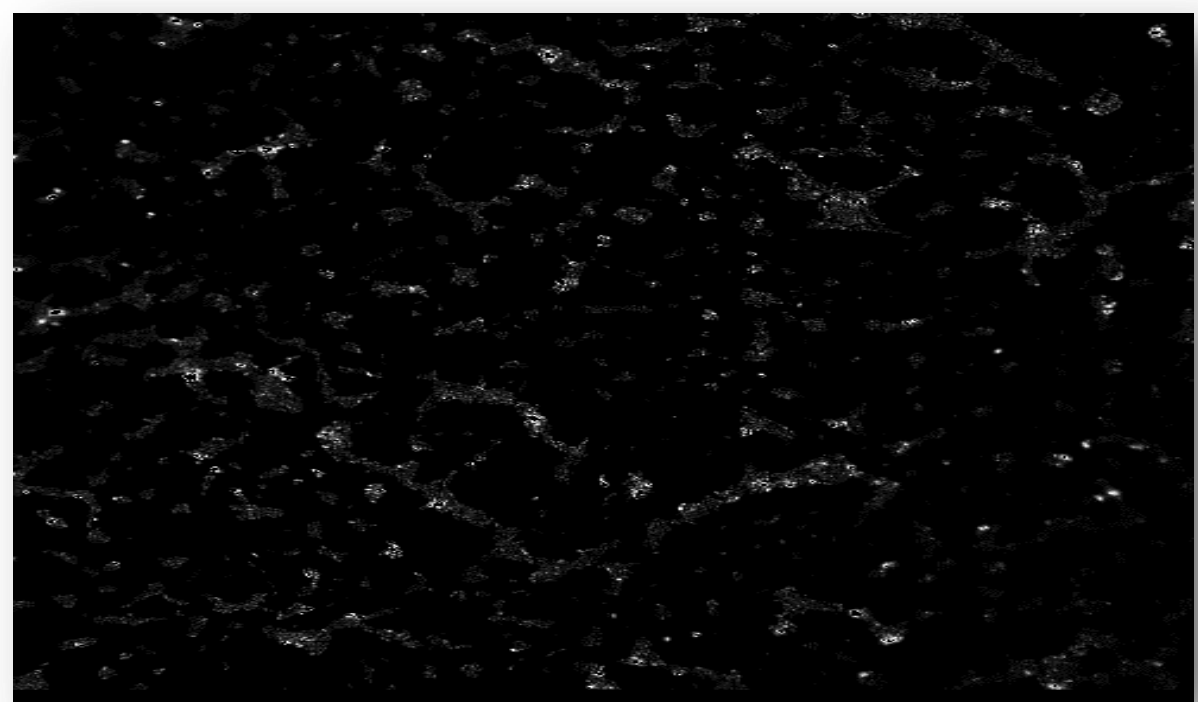

Figure 60. Replicate 2 for Arthrobacter spp. cells inoculated onto a black polycarbonate filter (viable culturable colonies were counted at about $10^{1} \mathrm{CFU} / \mathrm{mL}$ ). 


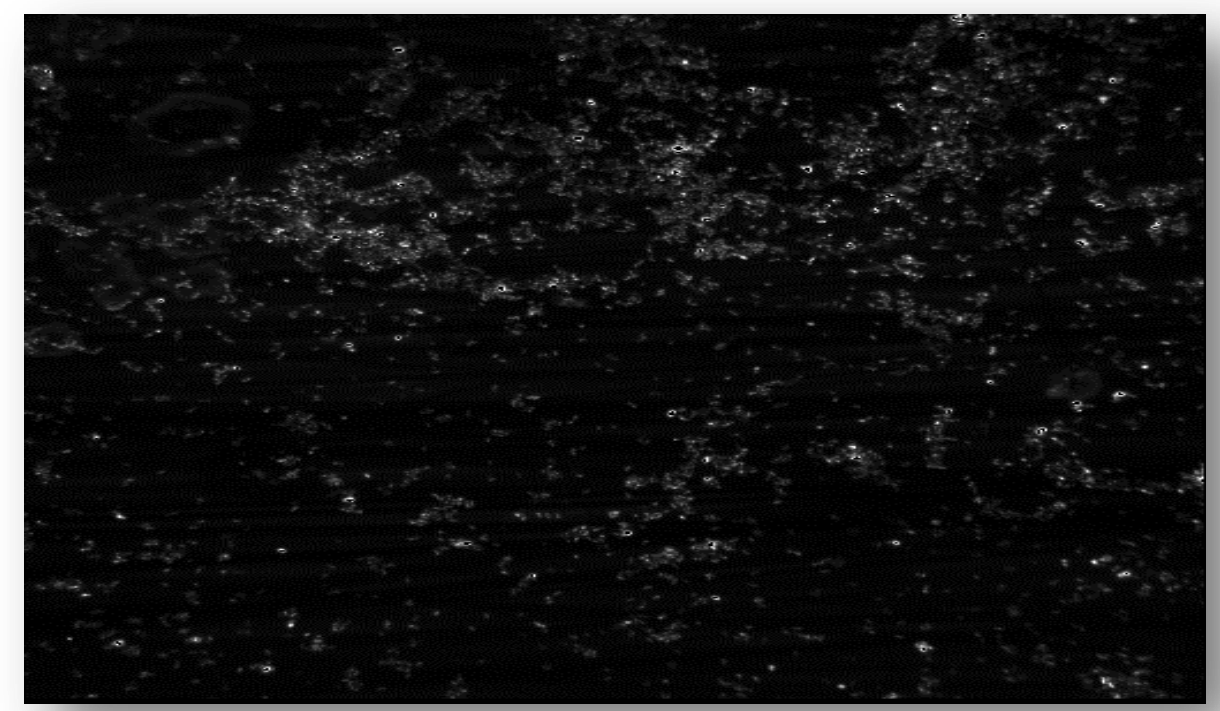

Figure 61. Replicate 1 for Arthrobacter spp. cells inoculated onto a microscope slide (viable culturable colonies were counted at about $10^{1} \mathrm{CFU} / \mathrm{mL}$ ).

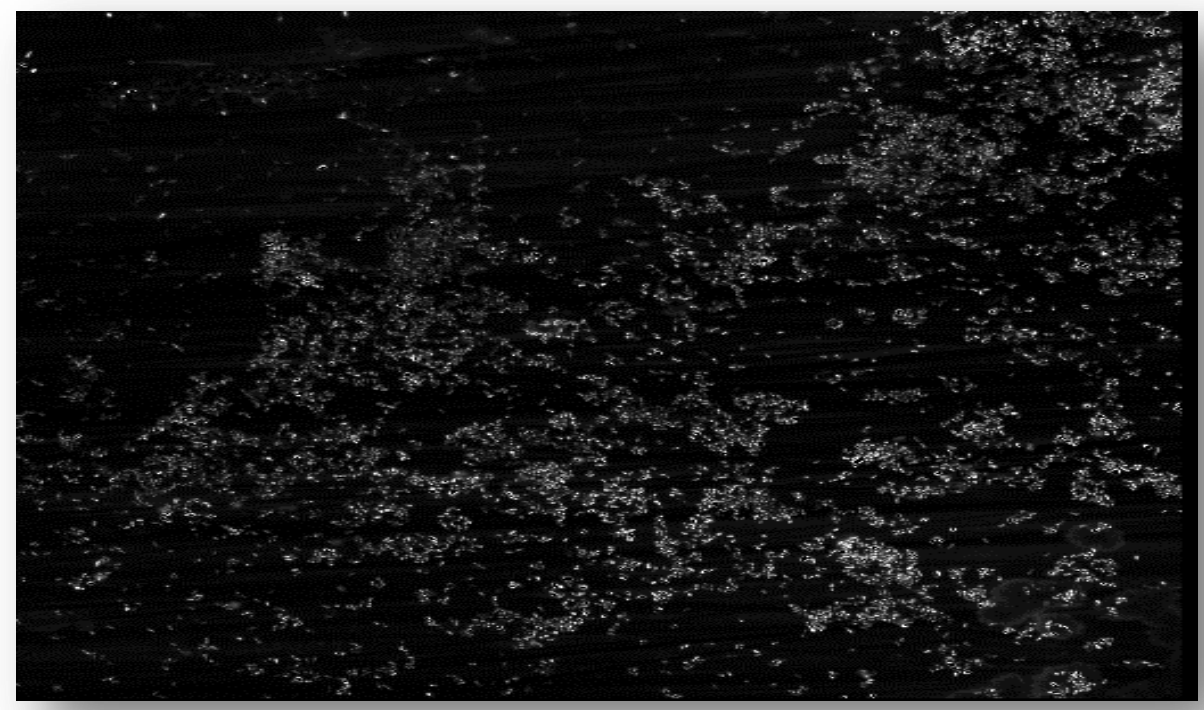

Figure 62. Replicate 2 for Arthrobacter spp. cells inoculated onto a microscope slide (viable culturable colonies were counted at about $\left.10^{1} \mathrm{CFU} / \mathrm{mL}\right)$. 


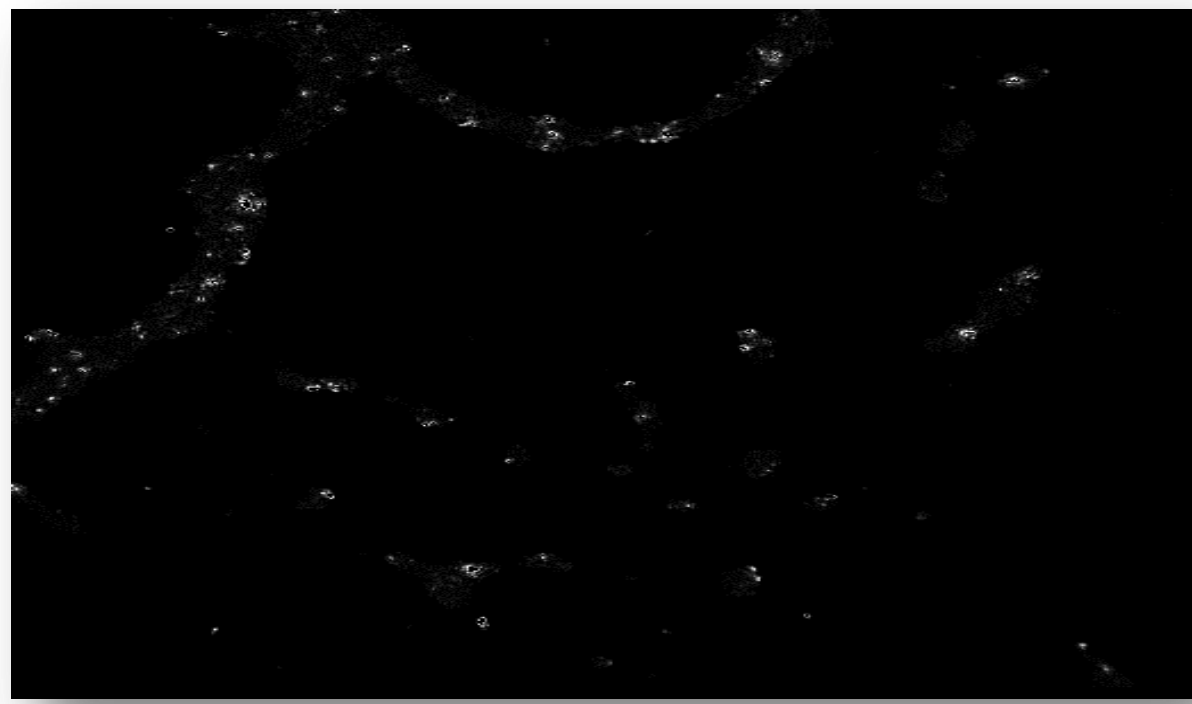

Figure 63. Replicate 1 for Arthrobacter spp. cells inoculated onto a black polycarbonate filter (viable culturable colonies were counted at about $10^{2} \mathrm{CFU} / \mathrm{mL}$ ).

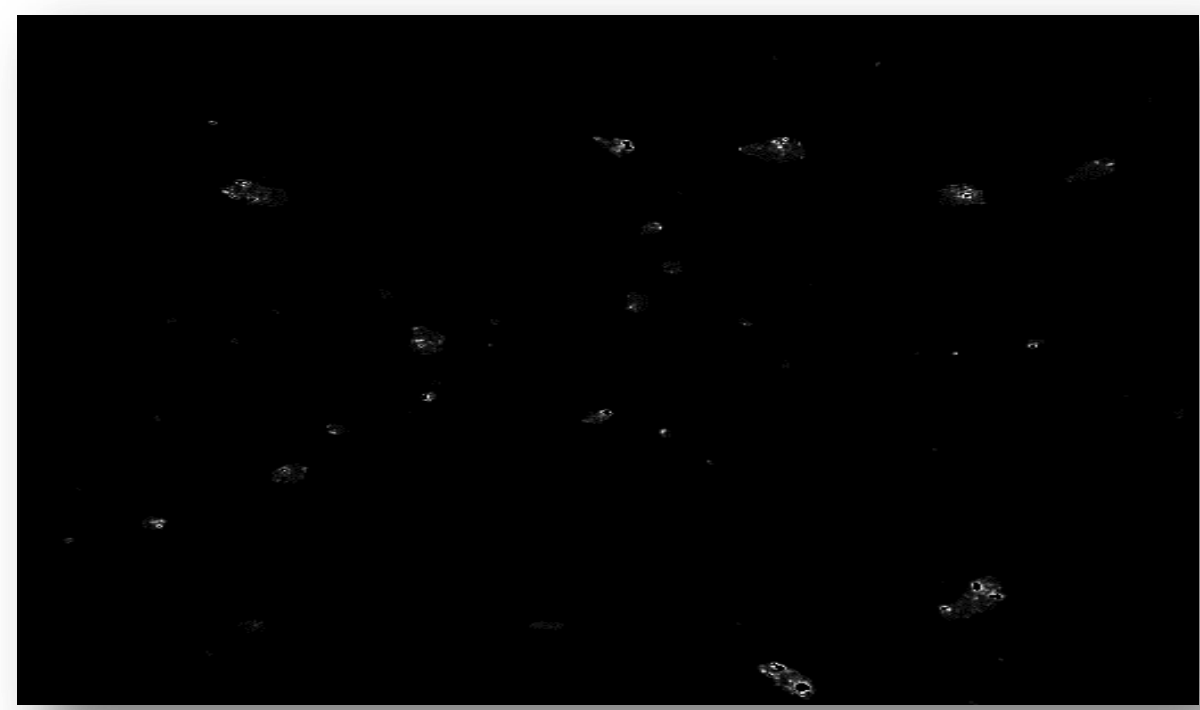

Figure 64. Replicate 2 for Arthrobacter spp. cells inoculated onto a black polycarbonate filter (viable culturable colonies were counted at about $10^{2} \mathrm{CFU} / \mathrm{mL}$ ). 


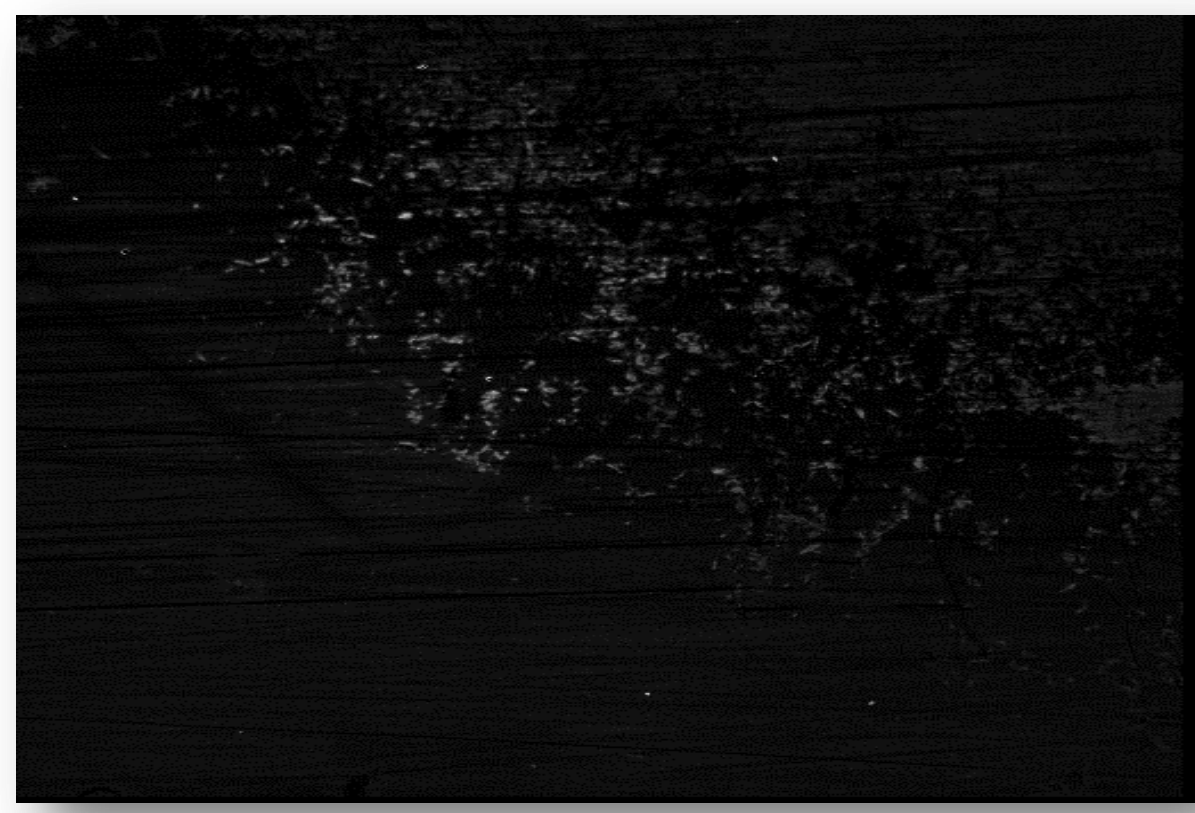

Figure 65. Replicate 1 for Arthrobacter spp. cells inoculated onto a microscope slide (viable culturable colonies were counted at about $10^{2} \mathrm{CFU} / \mathrm{mL}$ ). 


\section{BIBLIOGRAPHY}

1. Allocati, N., Masulli, M., Di Ilio, C. \& De Laurenzi, V. Die for the community: an overview of programmed cell death in bacteria. Cell Death Dis. 6, e1609 (2015).

2. Amann, R. I., Ludwig, W., Schleifer, K. H., Amann, R. I. \& Ludwig, W. Phylogenetic identification and in situ detection of individual microbial cells without cultivation . Phylogenetic Identification and In Situ Detection of Individual Microbial Cells without Cultivation. Microbiol. Rev. 59, 143-169 (1995).

3. Angert, E. R. Alternatives to binary fission in bacteria. Nat. Rev. Microbiol. 3, 214-224 (2005).

4. Aoki, K., Sugita, Y., Chijimatsu, M. \& Tazaki, K. Impacts of thermo-hydro-mechanical experiments on the microbial activity in compacted bentonite at the Kamaishi Mine, Northeast Japan. Appl. Clay Sci. 47, 147-154 (2010).

5. Argüelles, J. C. Physiological roles of trehalose in bacteria and yeasts: A comparative analysis. Arch. Microbiol. 174, 217-224 (2000).

6. Argueta, C., Yuksek, K., Patel, R. \& Summers, M. L. Identification of Nostoc punctiforme akinete-expressed genes using differential display. Mol. Microbiol. 61, 748-57 (2006).

7. Azeredo, J., Visser, J. \& Oliveira, R. Exopolymers in bacterial adhesion: Interpretation in terms of DLVO and XDLVO theories. Colloids Surfaces B Biointerfaces 14, 141-148 (1999).

8. Baker, G. C., Smith, J. J. \& Cowan, D. A. Review and re-analysis of domain-specific 16S primers. J. Microbiol. Methods 55, 541-555 (2003).

9. Beall, G. W., Sowersby, D. S., Roberts, R. D., Robson, M. H. \& Lewis, L. K. Analysis of Oligonucleotide DNA Binding and Sedimentation Properties of Montmorillonite Clay Using Ultraviolet Light Spectroscopy Analysis of Oligonucleotide DNA Binding and Sedimentation Properties of Montmorillonite Clay Using Ultraviolet Light Spectros. Biomacromolecules 10, 105-112 (2009).

10. Bigger, J. W. Treatment of Staphylococcal infections with penicillin by intermittent sterilisation. Lancet 2, 497-500 (1944).

11. Billi, D., D.J. Wright, R.F. Helm, T. Prickett, M. Potts, J. H. Engineering desiccation tolerance in Escherichia coli. Appl. Environ. Microbiol. 66, 1680-1684 (2000). 
12. Birch, K. et al. Technical Research and Development Program for Long-Term Management of Canada's Used Nuclear Fuel - Annual Report 2007. (NWMO TR-20081, 2008).

13. Blanton, M. V. \& Barnett, L. B. Adsorption of Ribonucleic Acid on Bentonite. Anal. Biochem. 32, 150-154 (1969).

14. Boivin-Jahns, V., Ruimy, R., Bianchi, a., Daumas, S. \& Christen, R. Bacterial diversity in a deep-subsurface clay environment. Appl. Environ. Microbiol. 62, 3405-3412 (1996).

15. Bowman, J. P., Jimenez, L., Rosario, I., Hazen, T. C. \& Sayler, G. S. Characterization of the methanotrophic bacterial community present in a trichloroethylene-contaminated subsurface groundwater site. Appl. Environ. Microbiol. 59, 2380-2387 (1993).

16. Bradbury, M. H. \& Baeyens, B. Porewater chemistry in compacted re-saturated MX-80 bentonite. J. Contam. Hydrol. 61, 329-338 (2003).

17. Brenner, K., You, L., Arnold, F. H. Engineering mircrobial consortia: A new frontier in synthetic biology. Trends Biotechnol. 26, 483-489 (2008).

18. Brown, A. D. Microbial water stress. Bacteriol. Rev. 40, 803-846 (1976).

19. Brown, M. J. \& Lester, J. N. Comparison of Bacterial Extracellular Polymer Extraction Methods Comparison of Bacterial Extracellular Polymer Extraction Methods. 40, 179-185 (1980).

20. Busch, P. L. \& Stumm, W. Chemical interactions in the aggregation of bacteria bioflocculation in waste treatment. Environ. Sci. Technol. 2, 49-53 (1968).

21. Cai, P., Huang, Q., Zhang, X. \& Chen, H. Adsorption of DNA on clay minerals and various colloidal particles from an Alfisol. Soil Biol. Biochem. 38, 471-476 (2006).

22. Calverys, J. P. \& Havarstein, L. S. Cannibalism and fratricide: mechanisms and raisons d'être. Nat Rev Micro 5, 219-229 (2007).

23. Carlucci, A. F. in Nutrients and microbial response to nutrients in seawater (eds. Colwell, R. R. \& Morita, R. Y.) 245-248 (University Park Press, 1974).

24. Carmona-Fontaine, C. \& Xavier, J. B. Altruistic cell death and collective drug resistance. Mol. Syst. Biol. 8, 627 (2012).

25. Chaloupka, J. \& Vinter, V. Programmed cell death in bacteria. Folia Microbiol. (Praha). 41, 451-464 (1996). 
26. Chi Fru, E. \& Athar, R. In situ bacterial colonization of compacted bentonite under deep geological high-level radioactive waste repository conditions. Appl. Microbiol.

Biotechnol. 79, 499-510 (2008).

27. Cho, W. J., Lee, J. O. \& Chun, K. S. The temperature effects on hydraulic conductivity of compacted bentonite. Appl. Clay Sci. 14, 47-58 (1999).

28. Cho, W. J., Lee, J. O. \& Kwon, S. An analysis of the factors affecting the hydraulic conductivity and swelling pressure of Kyungju Ca-bentonite for use as a clay-based sealing material for a high-level waste repository. Nucl. Eng. Technol. 44, 89-102 (2012).

29. Chodak, M., Gołębiewski, M., Morawska-Płoskonka, J., Kuduk, K. \& Niklińska, M. Soil chemical properties affect the reaction of forest soil bacteria to drought and rewetting stress. Ann. Microbiol. 65, 1627-1637 (2015).

30. Claverys, J.-P. \& Håvarstein, L. S. Cannibalism and fratricide: mechanisms and raisons d'être. Nat. Rev. Microbiol. 5, 219-229 (2007).

31. CNA. The canadian nuclear fact book. Canadian Nuclear Association (Canadian Nuclear Association, 2013). at <https://www.cna.ca/wp-content/uploads/2014/07/CNA-Factbook2013.pdf>

32. Colwell, R. R. Viable but nonculturable bacteria: a survival strategy. J. Infect. Chemother. 6, 121-125 (2000).

33. Comoli, L., Banfield, J. \& Barkeley, L. Ultra Small Bacteria Spotted. Nat. Commun. 6, 2015 (2015).

34. Costerton, J. W., Geesey, G. G. \& Cheng, K. J. How bacteria stick. Sci. Am. 238, 86-95 (1978).

35. Crowe, R.; Birch, K. ; Chen, J.; Doyle, D.; Garisto, F.; Gobien, M.; Hunt, N.; Hirschorn, S.; Hobbs, M.; Keech, P.; Kennell, L.;Kremer, E.; Maak, P.; McKelvie, J.; Medri, C.; Mielcarek, M.; Murchison, A.; Parmenter, A.;Ross, R.; Sykes, E.;Yang, T. Technical Program for Long-Term Management of Canada 's Used Nuclear Fuel-Annual Report 2009. (2010).

36. Csonka, L. N. Physiological and genetic responses of bacteria to osmotic stress. Microbiol. Rev. 53, 121-147 (1989).

37. Dahlback, B., Hermansson, M., Kjelleberg, S. \& Norkrans, B. The Hydrophobicity of Bacteria -- An Important Factor in Their Initial Adhesion at the Air-Water Interface. Arch Microbiol 128, 267-270 (1981). 
38. Davey, H. M. Life, death, and in-between: Meanings and methods in microbiology. Appl. Environ. Microbiol. 77, 5571-5576 (2011).

39. De Benito Armas, a., Padula, N. L., Setlow, B. \& Setlow, P. Sensitization of Bacillus subtilis spores to dry heat and desiccation by pretreatment with oxidizing agents. Lett. Appl. Microbiol. 46, 492-497 (2008).

40. de Goffau, M. C., van Dijl, J. M. \& Harmsen, H. J. M. Microbial growth on the edge of desiccation. Environ. Microbiol. 13, 2328-2335 (2011).

41. Delage, P., Howat, M. D. \& Cui, Y. J. The relationship between suction and swelling properties in a heavily compacted unsaturated clay. Eng. Geol. 50, 31-48 (1998).

42. Donlan, R. M., Costerton, J. W., Donlan, R. M. \& Costerton, J. W. Biofilms : Survival Mechanisms of Clinically Relevant Microorganisms. Clin. Microbiol. 15, 167-193 (2002).

43. Dubnau, D. \& Losick, R. Bistability in bacteria. Mol. Microbiol. 61, 564-572 (2006).

44. Ehrlich HL, N. D. K. in Geomicrobiology (CRC Press, 2008).

45. Euratom. Nuclear Science and Technology. European Commission Nuclear Science and Technology (2008).

46. Ferenci, T. Sensing nutrient levels in bacteria. Nat. Chem. Biol. 3, 607-8 (2007).

47. Fine, F. \& Gervais, P. Thermal destruction of dried vegetative yeast cells and dried bacterial spores in a convective hot air flow: strong influence of initial water activity. Environ. Microbiol. 7, 40-46 (2005).

48. Fletcher, M. in Bacterial Adhesion (eds. Savage, D. C. \& Fletcher, M.) 339-362 (Springer US, 1985). doi:10.1007/978-1-4615-6514-7_12

49. Fletcher, M. The effects of culture concentration and age, time, and temperature on bacterial attachment to polystyrene. Can. J. Microbiol. 23, 1-6 (1976).

50. Foladori, P., Bruni, L. \& Tamburini, S. Bacteria viability and decay in water and soil of vertical subsurface flow constructed wetlands. Ecol. Eng. 82, 49-56 (2015).

51. Fraenkel-Conrat, H., Singer, B. \& Tsugita, A. Purification of viral RNA by means of bentonite. Virology 14, 54-58 (1961).

52. Fredrickson, J. K. \& Onstott, T. C. Microbes deep inside the earth. Sci. Am. 275, 68-73 (1996). 
53. Fredrickson, J. K. et al. Pore-size constraints on the activity and survival of subsurface bacteria in a late cretaceous shale-sandstone sequence, northwestern New Mexico. Geomicrobiol. J. 14, 183-202 (1997).

54. Fredrickson, J. K. et al. Protein oxidation: key to bacterial desiccation resistance? ISME J. 2, 393-403 (2008).

55. Friedline, A. et al. Sterilization of hydrogen peroxide resistant bacterial spores with stabilized chlorine dioxide. AMB Express 5, 4-9 (2015).

56. Fru, E. C. \& Athar, R. In situ bacterial colonization of compacted bentonite under deep geological high-level radioactive waste repository conditions. Appl Microbiol Biotechnol 79, 499-510 (2008).

57. Fukunaga, S. et al. Investigation of Microorganisms in Bentonite Deposits. Geomicrobiol. J. 22, 361-370 (2005).

58. Geets, J., Boon, N. \& Verstraete, W. Strategies of aerobic ammonia-oxidizing bacteria for coping with nutrient and oxygen fluctuations. FEMS Microbiol. Ecol. 58, 1-13 (2006).

59. Gómez-Espina, R. \& Villar, M. V. Geochemical and mineralogical changes in compacted MX-80 bentonite submitted to heat and water gradients. Appl. Clay Sci. 47, 400-408 (2010).

60. Gomez-Jodar, I., Ros-Chumillas, M. \& Palop, A. Effect of heating rate on highly heatresistant spore-forming microorganisms. Food Sci. Technol. Int. 22, 164-172 (2016).

61. Gonzalez-Pastor, J. E., Hobbs, E. C. \& Losick, R. Cannibalism by Sporulating Bacteria. Science (80-. ). 301, 510-513 (2003).

62. Gottesman, S. Bacterial regulation: global regulatory networks. Annu. Rev. Microbiol. 18, 415-41 (1984).

63. Greenspan, L. Humidity Fixed Points of Binary Saturated Aqueous Solutions. J. Res. Natl. Bur. Stand. Chem. 81A, 89-96 (1977).

64. Hahn-Hagerdal, B. Water activity: a possible external regulator in biotechnical processes. Enzym. Microb Technol 8, 322-327 (1986).

65. Hall-Stoodley, L., Costerton, J. W. \& Stoodley, P. Bacterial biofilms: from the natural environment to infectious diseases. Nat. Rev. Microbiol. 2, 95-108 (2004).

66. Hall-Stoodley, L. \& Stoodley, P. Biofilm formation and dispersal and the transmission of human pathogens. Trends Microbiol. 13, 7-10 (2005). 
67. Hall, T. BioEdit: a user-friendly biological sequence alignment editor and analysis program for Windows 95/98/NT. Nucleic Acids Symposium Series 41, $95-98$ (1999).

68. Halverson, L. J. \& Firestone, M. K. Differential Effects of Permeating and Nonpermeating Solutes on the Fatty Acid Composition of Pseudomonas putida Differential Effects of Permeating and Nonpermeating Solutes on the Fatty Acid Composition of Pseudomonas putida $\uparrow$. 66, 2414-2421 (2000).

69. Hanson, C. W. \& Dworkin, M. Intracellular and extracellular nucleotides and related compounds during the development of Myxococcus xanthus. J Bacteriol 118, 486-496 (1974).

70. Harris, R. H. \& Mitchell, R. The role of polymers in microbial aggregation. Annu. Rev. Microbiol. 27, 27-50 (1973).

71. Hibbing, M. E., Fuqua, C., Parsek, M. R. \& Peterson, S. B. Bacterial competition: surviving and thriving in the microbial jungle. Nat. Rev. Microbiol. 8, 15-25 (2010).

72. Hoffmann, A. a. \& Harshman, L. G. Desiccation and starvation resistance in Drosophila: Patterns of variation at the species, population and intrapopulation levels. Heredity (Edinb). 83, 637-643 (1999).

73. Horikoshi, K. \& Grant, W. D. Extremophiles: Microbial Life in Extreme Environments. Wiley (Wiley-Liss INc., 1998).

74. International Energy Agengy. 2014 Key World Energy STATISTICS. International Energy Agency (2014). at <http://www.iea.org/publications/freepublications/publication/KeyWorld2014.pdf>

75. Jacques, M., Josi, K., Darrasse, a \& Samson, R. Xanthomonas axonopodis pv. phaseoli var. fuscans is aggregated in stable biofilm population sizes in the phyllosphere of fieldgrown beans. Appl. Environ. Microbiol. 71, 2008-15 (2005).

76. Johnson, L. H. et al. The disposal of Canada's nuclear fuel waste: the vault model for postclosure assessment. AECL (1994).

77. Johnson, L. H. Tait, J. C. Shoesmith, D. W. Shoesmith, J. L. Crosthwaite, Gray, M. N. The Disposal of Canada's Nuclear Fuel Waste: Engineering Barriers Alternatives. (1994).

78. Johnson, S. S., M.B. Hebsgaard, T.R.Christensen, M. Mastepanov, R. Nielsen, K. Munch., T. Brand, M.Thomas, P. Gilbert, M. T. Zuber, M. Bunce, R. Rønn, D. Gilichinsky, D. Froese, E. W. et al. Ancient bacteria show evidence of DNA repair. Proc Natl Acad Sci U $S$ A. 104, 14401-14405 (2007). 
79. Jordan, S., Hutchings, M. I. \& Mascher, T. Cell envelope stress response in Gram-positive bacteria. FEMS Microbiol. Rev. 32, 107-146 (2008).

80. Jorge, C. D., Fonseca, L. L., Boos, W. \& Santos, H. Role of periplasmic trehalase in uptake of trehalose by the thermophilic bacterium Rhodothermus marinus. J. Bacteriol. 190, 1871-1878 (2008).

81. Jouper-Jaan, A., A. E. Goodman, S. K. Bacteria starved for prolonged periods develop increased protection against lethal temperatures. FEMS Microbiol. Ecol. 101, 229-236 (1992).

82. Kaneko H, Takami H, Inoue A, H. K. Effects of hydrostatic pressure and temperature on growth and lipid composition of the inner membrane of barotolerant pseudomonas sp. BT1 isolated from the deep-sea. Biosci. Biotechnol. Biochem. 64, 72-79 (2000).

83. Kappen, L. \& Friedmann, E. I. Ecophysiology of lichens in the dry valleys of Southern Victoria Land, Antarctica. Polar Biol. 1, 227-232 (1983).

84. Karnland, O., Olsson, S. \& Nilsson, U. Mineralogy and sealing properties of various bentonites and smectite-rich clay materials. SKB Tech. Report, TR-06-30. (2006).

85. Karnland, O. \& Ab, C. T. Chemical and mineralogical characterization of the bentonite procedure in a KBS-3 repository. SKB Rep. TR-10-60 (2010).

86. Keymer, J. E. et al. Selfish and Altruistic Bacterial Populations Maximize Fitness Under Stress by Local Segregation. Nat. Preced. (2008).

87. Khanna, M. \& Stotzky, G. Transformation of bacillus subtilis by DNA bound on montmorillonite and effect of DNase on the transforming ability of bound DNA. Appl. Environ. Microbiol. 58, 1930-1939 (1992).

88. Kieft, T. L. et al. Microbiological comparisons within and across contiguous lacustrine, paleosol, and fluvial subsurface sediments. Appl. Environ. Microbiol. 61, 749-757 (1995).

89. King, F. Microbiologically Influenced Corrosion of Nuclear Waste Containers. Corrosion 65, 233-251 (2009).

90. King, F. Unsaturated copper corrosion gap analysis. NWMO (2006).

91. Kiviranta, L. \& Kumpulainen, S. Quality Control and Characterization of Bentonite Materials Quality Control and Characterization of Bentonite Materials. Posiva 84, (2011). 
92. Koch, D. Bentonites as a basic material for technical base liners and site encapsulation cut-off walls. Appl. Clay Sci. 21, 1-11 (2002).

93. Kremer, E. et al. Technical research and development program for long-term management of Canada's used nuclear fuel-Annual report 2008. (2009).

94. Krumholz, L.R., Mckinley, J.P., Ulrich, G.A., Suflita, J. M. Confined subsurface microbial communities in cretaceous rock. Nature 6620, 64-66 (1997).

95. Lalucat, J. et al. Biology of pseudomonas stutzeri. Microbiol. Mol. Biol. Rev. 70, 510-547 (2006).

96. Laroche, C. \& Gervais, P. Unexpected thermal destruction of dried, glass beadimmobilized microorganisms as a function of water activity. Appl. Environ. Microbiol. 69, 3015-3019 (2003).

97. Lauten, E. H., Pulliam, B. L., DeRousse, J., Bhatta, D. \& Edwards, D. a. Gene Expression, Bacteria Viability and Survivability Following Spray Drying of Mycobacterium smegmatis. Materials (Basel). 3, 2684-2724 (2010).

98. Lavie, S. \& Stotzky, G. Adhesion of the clay minerals montmorillonite, kaolinite, and attapulgite reduces respiration of Histoplasma capsulatum. Appl. Environ. Microbiol. 51, 65-73 (1986).

99. Ledenbach, L. H. \& Marshall, R. T. Introduction to the Microbiological Spoilage of Foods and Beverages. Food Microbiol. 1-40 (2009). doi:10.1007/978-1-4419-0826-1

100. Leggett, M. J., Mcdonnell, G., Denyer, S. P., Setlow, P. \& Maillard, J. Y. Bacterial spore structures and their protective role in biocide resistance. J. Appl. Microbiol. 113, 485-498 (2012).

101. Lewis, K. Persister cells and the riddle of biofilm survival. Biochem. 70, 267-274 (2005).

102. Li, G. et al. Surface contact stimulates the just-in-time deployment of bacterial adhesins. Mol. Microbiol. 83, 41-51 (2012).

103. Lindsay, D. \& von Holy, a. Bacterial biofilms within the clinical setting: what healthcare professionals should know. J. Hosp. Infect. 64, 313-325 (2006).

104. Lingnau, B. E., Graham, J., Yarechewski, D., Tanaka, N. \& Gray, M. N. Effects of temperature on strength and compressibility of sand-bentonite buffer. Eng. Geol. 41, 103115 (1996). 
105. Lisle, J. T. \& Priscu, J. C. The occurrence of lysogenic bacteria and microbial aggregates in the lakes of the McMurdo Dry Valleys, Antarctica. Microb. Ecol. 47, 427-439 (2004).

106. Liu, X.-M., Sheng, G.-P. \& Yu, H.-Q. DLVO approach to the flocculability of a photosynthetic H2-producing bacterium, Rhodopseudomonas acidophila. Environ. Sci. Technol. 41, 4620-5 (2007).

107. Logan, B. E. \& Hunt, J. R. Bioflocculation as a microbial response to substrate limitations. Biotechnol. Bioeng. 31, 91-101 (1988).

108. Loiseau, C. Transferts d'eau et couplages hydrome-caniques dans les barrieres ouvragees. (Ecole Nationale des Ponts et Chaussees, Paris, France, 2001).

109. Lorenz, M. G. \& Wackernagel, W. in Gene Transfers and Environment (ed. Gauthier, M. J.) 103-113 (Springer-Verlag Berlin Heidelberg, 1992). doi:10.1007/978-3-642-77450$8 \_12$

110. Lunau, M., Lemke, A., Walther, K., Martens-Habbena, W. \& Simon, M. An improved method for counting bacteria from sediments and turbid environments by epifluorescence microscopy. Environ. Microbiol. 7, 961-968 (2005).

111. Lynd, L. R., Weimer, P. J., van Zyl, W. H., Pretorius, I. S. Microbial cellulose utilization: fundamentals and biotechnology. Microbiol Mol Biol Rev 66, 506-577 (2002).

112. Makison, C. \& Swan, J. The effect of humidity on the survival of MRSA on hard surfaces . ndoor and Built Environment. 15, 85-91 (2006).

113. Maldonado, R., Jimenez, J. \& Casadesus, J. Changes of ploidy during the Azotobacter vinelandii growth cycle. J. Bacteriol. 176, 3911-3919 (1994).

114. Marshall, H. M. \& J., S. M. Characterization of Natural Organic Matter in Bentonite Clays. Nuclear Waste Management Organization (2014).

115. Marshall, K. C., Stout, R. \& Mitchell, R. Selective sorption of bacteria from seawater. Can. J. Microbiol. 17, 1413-1416 (1971).

116. Marshall, Kristin M. Nowaczyk II, Louis Morrissey, Travis R. Loeza, V., Halik, L. A., Skinner, G. E. \& Reddy, N. Rukma Fleischman, Gregory J. Larkin, J. W. Effect of Sporulation Temperature on the Resistance of Clostridium botulinum Type A Spores to Thermal and High Pressure Processing. J. Food Prot. 78, 146-150 (2015).

117. Masurat, P., Eriksson, S. \& Pedersen, K. Evidence of indigenous sulphate-reducing bacteria in commercial Wyoming bentonite MX-80. Appl. Clay Sci. 47, 51-57 (2010). 
118. Masurat, P., Eriksson, S. \& Pedersen, K. Evidence of indigenous sulphate-reducing bacteria in commercial Wyoming bentonite MX-80. Appl. Clay Sci. 47, 51-57 (2010).

119. Masurat, P., Eriksson, S. \& Pedersen, K. Microbial sulphide production in compacted Wyoming bentonite MX-80 under in situ conditions relevant to a repository for high-level radioactive waste. Appl. Clay Sci. 47, 58-64 (2009).

120. Matin, a, Auger, E. a, Blum, P. H. \& Schultz, J. E. Genetic basis of starvation survival in nondifferentiating bacteria. Annu. Rev. Microbiol. 43, 293-316 (1989).

121. Mattimore, V. \& Battista, J. R. Radioresistance of Deinococcus radiodurans: Functions necessary to survive ionizing radiation are also necessary to survive prolonged desiccation. J. Bacteriol. 178, 633-637 (1996).

122. McCaulou, D. R., Bales, R. C. \& Arnold, R. G. Effect of Temperature-Controlled Motility on Transport of Bacteria and Microspheres Through Saturated Sediment. Water Resour. Res. 31, 271-280 (1995).

123. McDougald, D., Rice, S. A., Weichart, D. \& Kjelleberg, S. Nonculturability: Adaptation or debilitation? FEMS Microbiol. Ecol. 25, 1-9 (1998).

124. McIntyre, H. J. et al. Trehalose biosynthesis in Rhizobium leguminosarum by. trifolii and its role in desiccation tolerance. Appl. Environ. Microbiol. 73, 3984-3992 (2007).

125. McKew, B. a, Taylor, J. D., McGenity, T. J. \& Underwood, G. J. C. Resistance and resilience of benthic biofilm communities from a temperate saltmarsh to desiccation and rewetting. ISME J. 5, 30-41 (2011).

126. McMurray, J. et al. Evolution of a Canadian deep geologic repository: base scenario Ontario power generation. (2003).

127. Mendelson, N. H., Chen, L. \& Thwaites, J. J. A new form of bacterial movement, dragging of multicellular aggregate structures over solid surfaces, is powered by macrofiber supercoiling. Res. Microbiol. 155, 113-127 (2004).

128. Mercier, J. \& Lindow, S. E. Role of leaf surface sugars in colonization of plants by bacterial epiphytes. Appl. Environ. Microbiol. 66, 369-374 (2000).

129. Mermillod-Blondin, F., Fauvet, G., Chalamet, A. \& Des Châtelliers, M. C. A comparison of two ultrasonic methods for detaching biofilms from natural substrata. Int. Rev. Hydrobiol. 86, 349-360 (2001).

130. Meunier, a. The Reactivity of Bentonites: A Review. An Application to Clay Barrier Stability for Nuclear Waste Storage. Clay Miner. 33, 187-196 (1998). 
131. Meyer, P. \& Dworkin, J. Applications of fluorescence microscopy to single bacterial cells. Res. Microbiol. 158, 187-194 (2007).

132. Mingarro, E. et al. Characterization of clay (bentonite)/crushed granite mixtures to build barriers against the migration of radionuclides: diffusion studies and physical properties: Task 3: Characterization of radioactive waste forms: A series of final reports (1985-89): No. (1991).

133. Miyamoto-shinohara, Y., Sukenobe, J., Imaizumi, T. \& Nakahara, T. Survival of freezedried bacteria. 24, 9-24 (2008).

134. Monier, J.-M. Biological significance of bacterial aggregation on leaf surfaces: the social life of epiphytic bacteria. Thesis (University of California, 2002). doi:10.16953/deusbed.74839

135. Monier, J.-M. \& Lindow, S. E. Differential survival of solitary and aggregated bacterial cells promotes aggregate formation on leaf surfaces. Proc. Natl. Acad. Sci. U. S. A. 100, 15977-15982 (2003).

136. Monier, J. \& Lindow, S. E. Spatial Organization of Dual-Species Bacterial Aggregates on Leaf Surfaces Spatial Organization of Dual-Species Bacterial Aggregates on Leaf Surfaces. Appl. Environ. Microbiol. 71, 5484-5493 (2005).

137. Monier, J. \& Lindow, S. E. Frequency , Size , and Localization of Bacterial Aggregates on Bean Leaf Surfaces. 70, 346-355 (2004).

138. Montes-H, G., Fritz, B., Clement, A. \& Michau, N. Modeling of transport and reaction in an engineered barrier for radioactive waste confinement. Appl. Clay Sci. 29, 155-171 (2005).

139. Montes-H, G., Fritz, B., Clement, a. \& Michau, N. Modelling of geochemical reactions and experimental cation exchange in MX80 bentonite. J. Environ. Manage. 77, 35-46 (2005).

140. Montes-H, G. \& Geraud, Y. Sorption kinetic of water vapour of MX80 bentonite submitted to different physical-chemical and mechanical conditions. Colloids Surfaces A Physicochem. Eng. Asp. 235, 17-23 (2004).

141. Montes-H, G. Duplay, J., Martinez, L. \& Mendoza, C. Swelling-shrinkage kinetics of MX80 bentonite. Appl. Clay Sci. 22, 279-293 (2003).

142. Morris, C. E. \& Monier, J. M. The ecological significance of biofilm formation by plantassociated bacteria. Annu Rev Phytopathol 41, 429-453 (2003). 
143. Morris, C. E., Monier, J. M. \& Jacques, M. a. A technique to quantify the population size and composition of the biofilm component in communities of bacteria in the phyllosphere. Appl. Environ. Microbiol. 64, 4789-4795 (1998).

144. Motamedi, M., Karland, O. \& Pedersen, K. Survival of sulfate reducing bacteria at different water activities in compacted bentonite. FEMS Microbiol. Lett. 141, 83-87 (1996).

145. Murrell, W. G. \& Scott, W. J. 411 The Heat Resistance of Bacterial Spores at Various Water Activities. J. Genet. Microbiol. 43, 411-425 (1966).

146. Muyzer, G., de Waal, E. C. \& Uitterlinden, a G. Profiling of complex microbial populations by denaturing gradient gel electrophoresis analysis of polymerase chain reaction-amplified genes coding for 16S rRNA. Appl. Environ. Microbiol. 59, 695-700 (1993).

147. Ndikubwimana, T. et al. Microalgae biomass harvesting by bioflocculation-interpretation by classical DLVO theory. Biochem. Eng. J. 101, 160-167 (2015).

148. Nuclear Waste Management Organization. Choosing a Way Forward. (2005). at <http://www.nwmo.ca/uploads_managed/MediaFiles/342_NWMO_Final_Study_Summar y_E.pdf>

149. NWMO. Implementing Adaptive Phased Management 2012 to 2016 The NWMO is guided by five fundamental values: Nuclear Waste Management Organization (2011).

150. Nyström, T. Nonculturable bacteria: Programmed survival forms or cells at death's door? BioEssays 25, 204-211 (2003).

151. Onstott, T. C. et al. Observations pertaining to the origin and ecology of microorganisms recovered from the deep subsurface of Taylorsville Basin. Geomicrobiol. J. 15, 353-385 (1998).

152. Or, D., Smets, B. F., Wraith, J. M., Dechesne, a. \& Friedman, S. P. Physical constraints affecting bacterial habitats and activity in unsaturated porous media - a review. Adv. Water Resour. 30, 1505-1527 (2007).

153. Or, D. \& Tuller, M. Flow in unsaturated fractured porous media: Hydraulic conductivity of rough surfaces. Water Resour. Res. 36, 1165-1177 (2000).

154. Otter, J. a. et al. Surface-attached cells, biofilms and biocide susceptibility: implications for hospital cleaning and disinfection. J. Hosp. Infect. 89, 16-27 (2015). 
155. Ouyang, S. \& Daemen, J. K. Sealing Performance of Bentonite and Bentonite/Crushed Rock Borehole Plugs. U.S. Nuclear Regulatory Commission (1992).

156. Pavoni, J. L., Tenney, M. W. \& Echelberger, W. F. Bacterial exocellular polymers and biological flocculation. Jof Water Pollut Control Fed 44, 414-429 (1972).

157. Pedersen, K., Motamedi, M., Karnland, O. \& Sandén, T. Mixing and sulphate-reducing activity of bacteria in swelling, compacted bentonite clay under high-level radioactive waste repository conditions. J. Appl. Microbiol. 89, 1038-1047 (2000).

158. Pedersen, K., Motamedi, M., Karnland, O. \& Sandén, T. Cultivability of microorganisms introduced into a compacted bentonite clay buffer under high-level radioactive waste repository conditions. Eng. Geol. 58, 149-161 (2000).

159. Pende, N. et al. Size-independent symmetric division in extraordinarily long cells. Nat Commun 5, (2014).

160. Perdrial, J. N., Warr, L. N., Perdrial, N., Lett, M. C. \& Elsass, F. Interaction between smectite and bacteria: Implications for bentonite as backfill material in the disposal of nuclear waste. Chem. Geol. 264, 281-294 (2009).

161. Postgate, J. R. \& Hunter, J. R. The Survival of Starved Bacteria. J. Genet. Microbiol. 29, 233-263 (1962).

162. Potts, M. Desiccation tolerance of prokaryotes. Microbiol. Rev. 58, 755-805 (1994).

163. Potts, M. Mechanisms of desiccation tolerance in cyanobacteria. Eur. J. Phycol. 34, 319328 (1999).

164. Potts, M. et al. Desiccation Tolerance of Prokaryotes : Application of Principles to Human Cells Desiccation Tolerance of Prokaryotes : to Human Cells ' of Principles Application. Integr. Comp. Biol. 45, 800-809 (2005).

165. Poulain, S., Sergeant, C., Simonoff, M., Le Marrec, C. \& Altmann, S. Microbial Investigations in Opalinus Clay, an Argillaceous Formation under Evaluation as a Potential Host Rock for a Radioactive Waste Repository. Geomicrobiol. J. 25, 240-249 (2008).

166. Pusch, R. \& Yong, R. Water saturation and retention of hydrophilic clay buffer microstructural aspects. Appl. Clay Sci. 23, 61-68 (2003).

167. Reina-Bueno, M. et al. Role of trehalose in heat and desiccation tolerance in the soil bacterium Rhizobium etli. BMC Microbiol. 12, 207 (2012). 
168. Reina-Bueno, M. et al. Role of trehalose in salinity and temperature tolerance in the model halophilic bacterium chromohalobacter salexigens. PLoS One 7, (2012).

169. Robine, E., Derangere, D., Attoui, M. \& Moreau, R. Aerobiocontamination testing procedure for evaluation of building materials and surface hygienic properties. J. Aerosol Sci. 29, 551-552 (1998).

170. Rodríguez, Y., Ballester, A., Blázquez, M. L., González, F. \& Muñoz, J. A. Study of Bacterial Attachment During the Bioleaching of Pyrite, Chalcopyrite, and Sphalerite. Geomicrobiol. J. 20, 131-141 (2003).

171 Ronan, E. Investigating microbial ecology at solid-air interfaces. (Ryerson University, 2011).

172. Ronan, E., Yeung, C. W., Hausner, M. \& Wolfaardt, G. M. Interspecies interaction extends bacterial survival at solid-air interfaces. Biofouling 29, 1087-96 (2013).

173. Roszak, D. B. \& Colwell, R. R. Survival strategies of bacteria in the natural environment. Microbiol. Rev. 51, 365-379 (1987).

174. Rozen, D. E., Philippe, N., Arjan De Visser, J., Lenski, R. E. \& Schneider, D. Death and cannibalism in a seasonal environment facilitate bacterial coexistence. Ecol. Lett. 12, 34 44 (2009).

175. Saiyouri, N., Hicher, P. Y. \& Tessier, D. Microstructural approach and transfer water modelling in highly compacted unsaturated swelling clays. Mech. Cohesive-frictional Mater. 5, 41-60 (2000).

176. Savage, D. An Assessment of the Impact of the Long Term Evolution of Engineered Structures on the Safety-Relevant Functions of the Bentonite Buffer in a HLW Repository. National Cooperative for the Disposal of Radioactive Waste (2014).

177. Schimel J, Balser TC, W. M. Microbial stress-response physiology and its implications for ecosystem function. Ecology 88, 1386-1394 (2007).

178. Selinummi, J., Seppälä, J., Yli-Harja, O. \& Puhakka, J. a. Software for quantification of labeled bacteria from digital microscope images by automated image analysis.

Biotechniques 39, 859-862 (2005).

179. Setlow, P. Spores of Bacillus subtilis: Their resistance to and killing by radiation, heat and chemicals. J. Appl. Microbiol. 101, 514-525 (2006).

180. Shapiro, J. a. Thinking about bacterial populations as multicellular organisms. Annu. Rev. Microbiol. 52, 81-104 (1998). 
181. Shoesmith, D. W. \& Zagidulin, D. The corrosion of zirconium under deep geologic repository conditions. J. Nucl. Mater. 418, 292-306 (2011).

182. Shoesmith, D. W. \& Zagidulin, D. The corrosion of zirconium under deep geolical repository conditions. J. Nucl. Mater. 418, 292-306 (2011).

183. Singh, S. C., Sinha, R. P. \& Häder, D. Role of Lipids and Fatty Acids in Stress Tolerance in Cyanobacteria. Acta Protozool. 41, 297-308 (2002).

184. Sobeck, D. C. \& Higgins, M. J. Examination of three theories for mechanisms of cationinduced bioflocculation. Water Res. 36, 527-538 (2002).

185. Stevens, T. Lithoautotrophy in the subsurface. FEMS Microbiol. Rev. 20, 327-337 (1997).

186. Stewart, P. S. \& Franklin, M. J. Physiological heterogeneity in biofilms. Nat. Rev. Microbiol. 6, 199-210 (2008).

187. Streeter, J. G. Effect of trehalose on survival of Bradyrhizobium japonicum during desiccation. J. Appl. Microbiol. 95, 484-491 (2003).

188. Stroes-Gascoyne, S. et al. Occurrence and identification of microorganisms in compacted clay-based buffer material designed for use in a nuclear fuel waste disposal vault. Can. J. Microbiol. 43, 1133-1146 (1997).

189. Stroes-Gascoyne, S., J. M. W. Microbial studies in the canadian nuclear fuel waste management program. Microb. Stud. Can. Nucl. fuel waste Manag. Progr. 20, 573-590 (1997).

190. Stroes-Gascoyne, S., Hamon, C. J., Dixon, D. a. \& Martino, J. B. Microbial analysis of samples from the tunnel sealing experiment at AECL's Underground Research Laboratory. Phys. Chem. Earth 32, 219-231 (2007).

191. Stroes-Gascoyne, S., Hamon, C. J., Maak, P. \& Russell, S. The effects of the physical properties of highly compacted smectitic clay (bentonite) on the culturability of indigenous microorganisms. Appl. Clay Sci. 47, 155-162 (2010).

192. Stroes-Gascoyne, S. \& Sargent, F. P. The Canadian approach to microbial studies in nuclear waste management and disposal. J. Contam. Hydrol. 35, 175-190 (1998).

193. Stroes-Gascoyne, S. et al. Microbial Community Analysis of Opalinus Clay Drill Core Samples from the Mont Terri Underground Research Laboratory, Switzerland. Geomicrobiol. J. 24, 1-17 (2007). 
194. Stroes-Gascoyne, S. \& West, J. M. Microbial Considerations and Studies in the Canadian Nuclear Fuel Waste Management Program. MRS Proc. 353, 537-590 (1997).

195. Stroes-Gascoyne, S. Microbial occurrence in bentonite-based buffer, backfill and sealing materials from large-scale experiments at AECL's Underground Research Laboratory. Appl. Clay Sci. 47, 36-42 (2010).

196. Stroes-Gascoyne, S., Hamon, C. J. \& Maak, P. Limits to the use of highly compacted bentonite as a deterrent for microbiologically influenced corrosion in a nuclear fuel waste repository. Phys. Chem. Earth 36, 1630-1638 (2011).

197. Stroes-Gascoyne \& Hamon, C. J. The Effects of Elevated Temperatures on the Viability and Culturability of Bacteria Indigenous to Wyoming MX-80 Bentonite. (NMWO TR2010-08, 2010).

198. Tang, A. M., Y. J. C. Effects of mineralogy on thermo-hydro-mechanical parameters of MX80 bentonite. J. Rock Mech. Geotech. Eng. 2, 91-96 (2010).

199. Tang, A.-M. \& Cui, Y.-J. Controlling suction by vapour equilibrium technique at different temperatures, application to the determination of the water retention properties of MX80 clay. 1-32 (2007). doi:10.1139/T04-082

200. Tang, A.-M., Cui, Y.-J. \& Barnel, N. Thermo-mechanical behaviour of a compacted swelling clay. 1-34 (2008). doi:10.1680/geot.2008.58.1.45

201. Tenney, M. W. \& Verhoff, F. H. Chemical and autoflocculation of microorganisms in biological wastewater treatment. Biotechnol. Bioeng. 15, 1045-1073 (1973).

202. Terracciano, J. S., Rapaport, E. \& Kashket, E. R. Stress- and Growth Phase-Associated Proteins of Clostridium acetobutylicum. Appl. Environ. Microbiol. 54, 1989-95 (1988).

203. Teschler, J. K. et al. Living in the matrix: assembly and control of Vibrio cholerae biofilms. Nat Rev Micro 13, 255-268 (2015).

204. Theng, B. K. G. \& Orchard, V. A. in Environmental Impacts of Soil Component Interactions: Metals, Other Inorganics, and Microbial Activities (eds. Huang, J., Berthelin, J. M., Bollag, W. B. \& McGill, A. L.) 123-143 (CRC Lewis Publishers, 1995).

205. Tirumalai, M. R. \& Fox, G. E. An ICEBs1-like element may be associated with the extreme radiation and desiccation resistance of Bacillus pumilus SAFR-032 spores. Extremophiles 17, 767-774 (2013). 
206. Tong, X., Yuan, L., Luo, L. \& Yin, X. Characterization of a selenium-tolerant rhizosphere strain from a novel se-hyperaccumulating plant Cardamine hupingshanesis. Sci. World J. 2014, (2014).

207. Treweek, G. P., Montgomery, J. M., Morgan, J. J. \& Treweek, P. Determination flocculant aggregating particulate of effectiveness suspended matter in. Water Pollut. Control Fed. 51, 1859-1877 (1979).

208. Tsuneda, S., Aikawa, H., Hayashi, H., Yuasa, A. \& Hirata, A. Extracellular polymeric substances responsible for bacterial adhesion onto solid surface. FEMS Microbiol. Lett. 223, 287-292 (2003).

209. Tzeng, L. F., Ellis, T. N. \& Singer, M. DNA replication during aggregation phase is essential for Myxococcus xanthus development. J. Bacteriol. 188, 2774-2779 (2006).

210. Ulrich, W. Rethinking critically reflective research practice: Beyond popper's critical rationalism. J. Res. Pract. 2, (2006).

211. Urbain, V., Block, J. C. \& Manem, J. Bioflocculation in activated sludge: an analytic approach. Water Res. 27, 829-838 (1993).

212. Van de Peer, Y., Chapelle, S. \& De Wachter, R. A quantitative map of nucleotide substitution rates in bacterial rRNA. Nucleic Acids Res. 24, 3381-3391 (1996).

213. Van Dierdonck, J., Van den Broeck, R., Vervoort, E., Van Impe, J. \& Smets, I. The effect of alternating influent carbon source composition on activated sludge bioflocculation. $J$. Biotechnol. 167, 225-234 (2013).

214. van Loosdrecht, M. C., Lyklema, J., Norde, W., Schraa, G. \& Zehnder, A. J. Electrophoretic mobility and hydrophobicity as a measured to predict the initial steps of bacterial adhesion. Appl. Environ. Microbiol. 53, 1898-901 (1987).

215. Veening, J.-W. et al. Bet-hedging and epigenetic inheritance in bacterial cell development. Proc. Natl. Acad. Sci. U. S. A. 105, 4393-4398 (2008).

216. Vela, G. R. \& State, N. T. Cysts of Azotobacter vinelandii with Double. 112, 615-617 (1972).

217. Velicer, G. J. Social strife in the microbial world. Trends Microbiol. 11, 330-337 (2003).

218. Villar, M. V. Caracterizacion termo-hidro-mecanica de una bentonita de Cabo de Gata. (Universidad Complutense de Madrid, Madrid, Spain, 2000). 
219. Villar, M. V. \& Lloret, a. Influence of temperature on the hydro-mechanical behaviour of a compacted bentonite. Appl. Clay Sci. 26, 337-350 (2004).

220. Whittenbury, R. \& Dow, C. S. differentiation in Rhodomicrobium vannielii and other budding and prosthecate Morphogenesis and Differentiation in Rhodomicrobium vannielii and Other Budding and Prosthecate Bacteria. Arch. Mikrobiol. 41, 754-808 (1977).

221. Wilén, B. M., Jin, B. \& Lant, P. The influence of key chemical constituents in activated sludge on surface and flocculating properties. Water Res. 37, 2127-2139 (2003).

222. WNA. Natural Resource Canada. Government of Canada (2015). at <http://www.worldnuclear.org/information-library/facts-and-figures/world-nuclear-power-reactors-anduranium-requireme.aspx>

223. Wolfaardt, G. M. \& Korber, D. R. Near-field Microbiological Considerations Relevant to a Deep Geological Repository for Used Nuclear Fuel - State of Science Review. (2012).

224. Xie, B., Gu, J. \& Lu, J. Surface properties of bacteria from activated sludge in relation to bioflocculation. J. Environ. Sci. (China) 22, 1840-1845 (2010).

225. Yazgi, H., M.H. Uyanik, M. Ertek, A. E. Aktas, H. Igan, A. A. Survival of certain nosocomial infectious agents on the surfaces of various covering materials. Turkish $J$. Med. Sci. 39, 619-622 (2009).

226. Yeung, C. W., Woo, M., Lee, K. \& Greer, C. W. Characterization of the bacterial community structure of Sydney Tar Ponds sediment. Can. J. Microbiol. 57, 493-503 (2011).

227. Yurtsev, E. A., Chao, H. X., Datta, M. S., Artemova, T. \& Gore, J. Bacterial cheating drives the population dynamics of cooperative antibiotic resistance plasmids. Mol. Syst. Biol. 9, 1-7 (2013). 